\title{
ipen
}

AUTARQUIA ASSOCIADA À UNIVERSIDADE DE SÃO PAULO

\section{EFEITO DO PROCESSAMENTO POR IONIZAÇÃO, CALOR E MICRO-ONDAS NA DEGRADAÇÃO DO ÁCIDO FÓLICO}

MICHEL MOZEIKA ARAÚJO

Tese apresentada como parte dos requisitos para obtenção do grau de Doutor em Ciências na Área de Tecnologia Nuclear - Aplicações.

Orientadora:

Profa. Dra. Anna Lucia Casañas Haasis Villavicencio 
Aos meus pais, João e Vera, pelo amor eterno e apoio constante. 


\section{AGRADECIMENTOS}

À Dra. Anna Lucia C. H. Villavicencio por todos os ensinamentos, confiança e apoio durante esta longa jornada;

Ao Dr. Eric Marchioni por ter me recebido junto à "Equipe de Chimie Analytique des Molécules Bioactives" da Universidade de Strasbourg (UdS) e por ter contribuído enormemente no desenvolvimento deste projeto;

Ao Dr. Wilson Aparecido Parejo Calvo e a Dra. Margarida Hamada, pela presença constante e ajuda na resolução dos problemas do dia-a-dia;

Um "merci" especial à Martine Bergaentzlé e Minjie Zhao por compartilhar todo seu conhecimento e tempo e contribuir na conclusão deste trabalho;

Aos Drs. Françoise Bindler, Saïd Ennahar e Christophe Marcic pelo esclarecimento de dúvidas e constante troca de ideias;

Um "merci" também especial aos estagiários Emeline Hahn, Pierre Zimmermann, Thomas di Pascoli que me ajudaram tanto, tanto para o avanço da pesquisa;

Aos meus colegas de laboratório e amigos do lado brasileiro Patrícia, Renato, Gustavo, Flávio, Amanda, Eliana, Leila, Simone, Camilo, Priscila, Mariana pela presença diária e suporte quando precisei;

Aos meus amigos doutorandos do lado francês Etienne, Eli, Omar, Pierre, Celine, Erwann, Li, Matthieu, Remmelt e Gildas pelo constante suporte científico, pelos momentos de descontração passados juntos e lembranças que me deixam;

Aos meus também colegas de trabalho do lado francês Ali, Ines, Oscar Barbosa, Carole, Zhiang com quem compartilhei tantos momentos;

Aos alunos de iniciação científica que passaram pelo laboratório Citra, Tamime, Mathieu, Veronique, Myriam, Camille, Cyril pela compreensão e bom ambiente de trabalho;

À Aérial, em especial Florentz Kuntz, Alan Strasser e Dalal AoudeWerner por cederem suas instalações para a realização das irradiações e Ludovic, Julie e Bernard por todo o suporte; 
Aos secretários Marcos e Claudia e à "secretaire" Myriam Benelhocibe pelo imprescindível auxílio nos assuntos administrativos;

À Divisão de Ensino do IPEN por ter ajudado a concretizar este projeto e viabilizar o doutorado sanduíche;

A todos os outros amigos que conquistei no IPEN e na UdS, importantes tanto nos momentos sérios como nos de descontração durante este período;

Aos demais profissionais do Centro de Tecnologia das Radiações, pósgraduandos e alunos de iniciação científica pelo convívio harmonioso e enriquecedor;

Aos meus pais, João e Vera, minha irmã Tamara, meu cunhado Lucas e minha chérie Fanny pelo constante apoio, paciência, estímulo e acima de tudo, pelo eterno amor incondicional;

À minha segunda família, Pascale, Jean-Marc, Claire, Karime, PaulAndré por todo o suporte e por me fazer sentir "chez moi";

Ao CNPq pela bolsa de doutorado concedida e auxílio que permitiram o desenvolvimento deste projeto;

À CAPES pela bolsa de doutorado sanduíche que permitiu um avanço substancial da minha pesquisa.

À todos os demais amigos, colegas e pessoas que me ajudaram neste caminho de forma direta ou indireta, um obrigado. 
"O sucesso é o resultado do esforço e o esforço nos torna fortes" (La réussite est au bout de l'effort et l'effort fait les forts) Provérbio africano. 


\title{
EFEITO DO PROCESSAMENTO POR IONIZAÇÃO, CALOR E MICRO-ONDAS NA DEGRADAÇÃO DO ÁCIDO FÓLICO
}

\author{
Michel Mozeika Araújo \\ RESUMO
}

Os folatos, vitaminas hidrossolúveis do grupo $B$ estão envolvidos em importantes processos bioquímicos como a síntese e reparação de DNA. O metabolismo humano não é capaz de sintetizar folatos e necessita obtê-los da dieta. $O$ ácido fólico $(\mathrm{AF})$, vitâmero sintético e estável dos folatos, é usado para a fortificação de alimentos como farinha de trigo em função do baixo custo e grande biodisponibilidade. O AF compreende uma pterina, um ácido $p$-aminobenzóico e um ácido glutâmico. É um composto sensível, facilmente degradado em solução aquosa por luz ultravioleta e visível. O tratamento por ionização de alimentos elimina ou reduz patógenos e insetos, aumenta o tempo de estocagem e a vida de prateleira dos alimentos. A irradiação de alimentos utiliza elétrons acelerados, raios gama ou raios $X$. Os objetivos deste estudo foram avaliar os efeitos dos tratamentos com feixe de elétrons, térmico em estufa e em forno micro-ondas na degradação do AF em solução, suspensão e pó. Também foi desenvolvido um método de extração por solvente pressurizado do AF de farinha de trigo fortificada e de pães. Os diferentes processamentos degradaram o AF e os principais produtos de degradação foram identificados por LC/MS/MS como sendo: 6carboxipterina (PCA), ácido $p$-aminobenzóico (PABA), p-aminobenzoil-L-ácido glutâmico (pABGA) e ácido pteroico (PA). Em soluções de $A F$ irradiadas foram identificados novos radioprodutos: $n$-(4-nitrobenzoil)-L-ácido glutâmico (pNBGA), xantopterina (XA) e 2-amino-6-(hidroximetil)pteridina-4(1H)-one (AHMP). Uma extração completa do AF por solvente pressurizado foi realizada com sucesso em amostras de farinha de trigo fortificada e pães em apenas 15 minutos. A panificação reduziu em até $57 \%$ o teor de AF no produto final. Por outro lado, a irradiação de farinha de trigo fortificada com doses de radiação até $10 \mathrm{kGy}$ não alterou o conteúdo de AF. Esta tecnologia mostrou-se eficaz para tratamento de farinha de trigo e poderia ser utilizada como medida fitossanitária. 


\title{
IONIZING, HEAT AND MICROWAVE PROCESSING EFFECTS ON FOLIC ACID DEGRADATION
}

\author{
Michel Mozeika Araújo
}

\begin{abstract}
Folates, water soluble vitamins of B group, are involved in important biochemical processes such as DNA synthesis and repair. The human metabolism is not able to synthesize folate and needs to get them from the diet. Folic acid, a synthetic and stable folate vitamer, is used in food fortification such as wheat flour due to the low cost and high bioavailability. Folic acid is composed of a pterin, the $p$-aminobenzoic acid and glutamate. This sensitive compound is easily degraded in aqueous solution by ultraviolet and visible light yielding various by-products. lonizing radiation treatment of food reduces or eliminates pathogens and insects, increases food shelf life and storage. Irradiation is a food preserving process which uses accelerated electrons, gamma rays or X-rays. The objectives of this study were to evaluate the effects of electron beam treatment, heat treatment in oven and microwave in folic acid degradation in solution, in suspension and in powder. A pressurized solvent extraction method was also developed to folic acid fortified wheat flour and bread. The different processing degraded folic acid and the main degradation products were identified by LC/MS/MS as 6-carboxipterin (PCA), p-aminobenzoic acid (PABA), p-aminobenzoyl-L-glutamic acid (pABGA) and pteroic acid (PA). In irradiated folic acid solutions were identified new radioproducts: $n$-(4-nitrobenzoyl)-L-glutamic acid (pNBGA), xanthopterin (XA) and 2-amino-6-(hydroxymethyl)-pteridine-4(1H)-one (AHMP). A complete extraction of folic acid by pressurized solvent extraction was successfully performed on samples of fortified wheat flour and bread in just 15 minutes. Bread manufacturing reduced up to $57 \%$ folic acid content in the final product. Irradiation up to $10 \mathrm{kGy}$ did not alter folic acid content of fortified wheat flour. Irradiation technology proved to be effective for the treatment of fortified wheat flour and could be used as a phytosanitary measure.
\end{abstract}




\section{SUMÁRIO}

Página

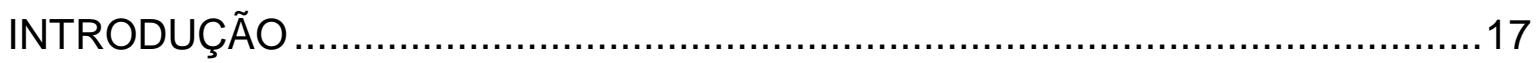

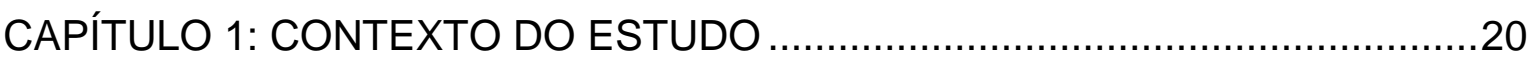

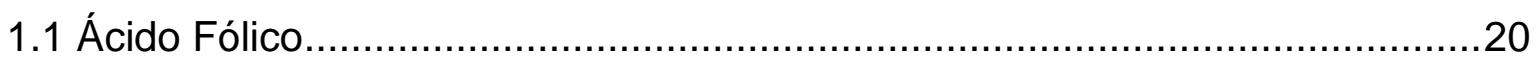

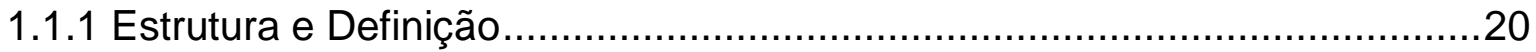

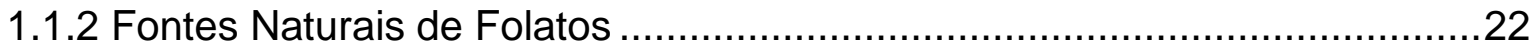

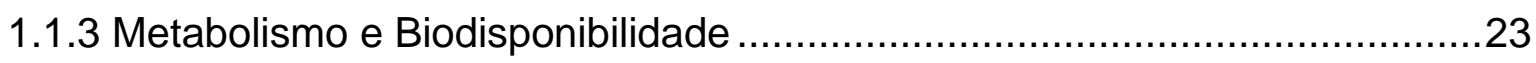

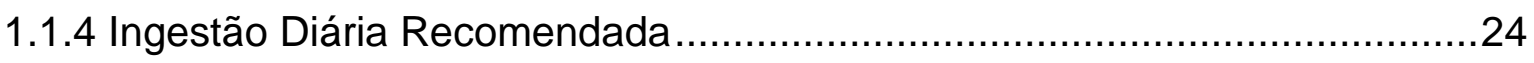

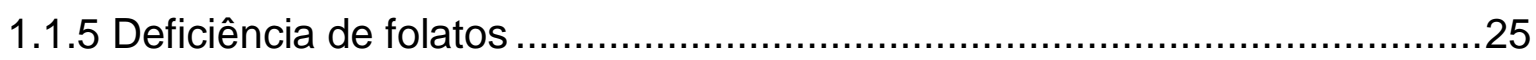

1.1.6 Fortificação de Alimentos com Ácido Fólico ............................................26

1.1.7 Efeito dos Processamentos de Alimentos na Estabilidade do AF ................28 CAPÍTULO 2: ESTUDO DOS EFEITOS DE DIFERENTES PROCESSAMENTOS DE ALIMENTOS NO ÁCIDO FÓLICO E ELUCIDAÇÃO DOS PRODUTOS DE

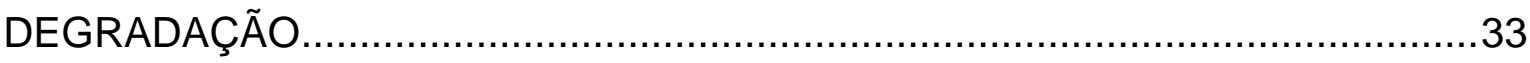

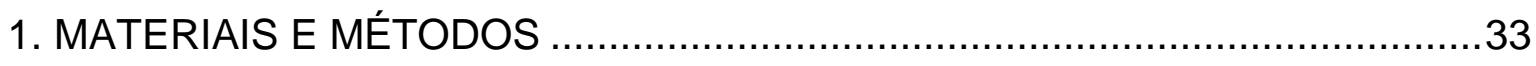

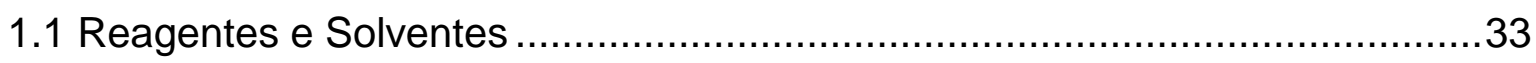

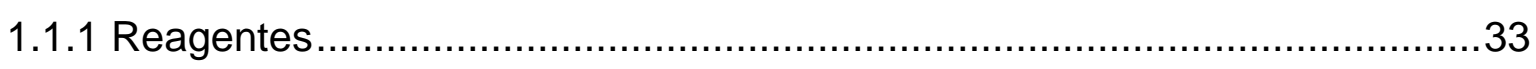

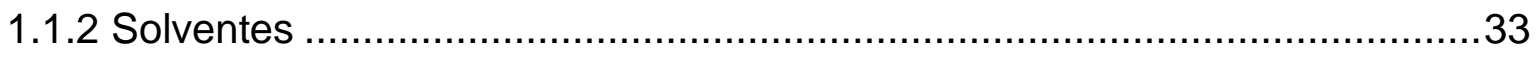

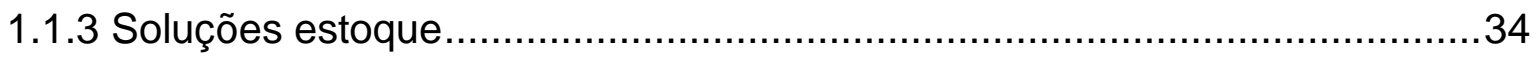

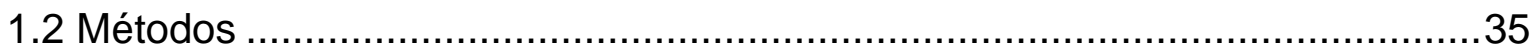

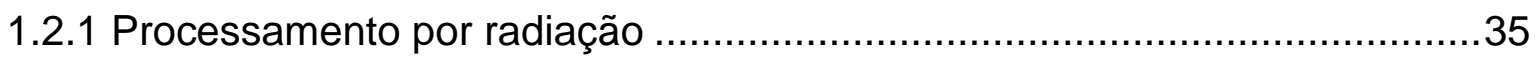

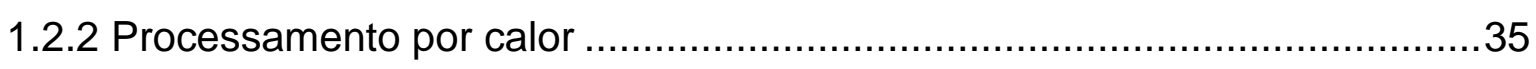

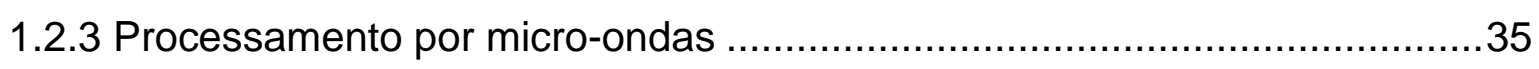

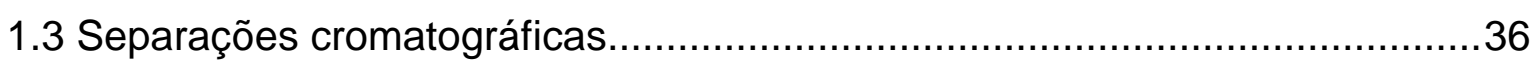

1.3.1 Cromatografia Líquida de Alta Eficiência (HPLC) ……………................36

1.3.1.1 Análise Quantitativa do AF e de seus produtos de degradação.................37

1.3.2 Cromatografia Líquida de Alta Eficiência para Coleção de Frações ..............38

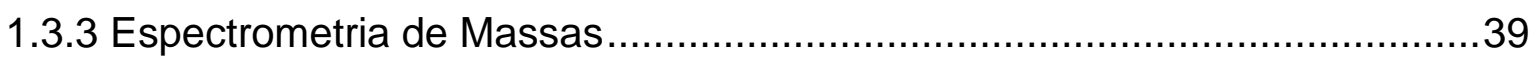

1.3.4 Espectrometria de Massas de Alta Resolução...........................................40

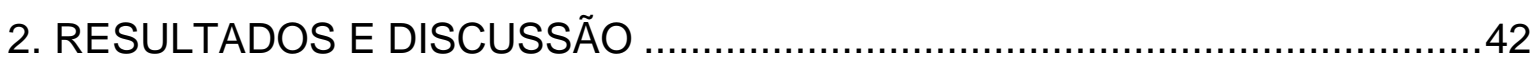

2.1 Efeitos dos diferentes processamentos na degradação do AF ......................42

2.1.1 Efeito do processamento por radiação ionizante ..........................................42 
2.1.2 Efeito do processamento por aquecimento em estufa 47

2.1.1 Efeito do processamento por micro-ondas

2.2. Identificação dos produtos de degradação do AF decorrente dos diferentes processamentos. .51

2.2.1 Processamento por radiação ionizante ...............................................52

2.2.2 Processamento do AF em pó por aquecimento em estufa..........................77

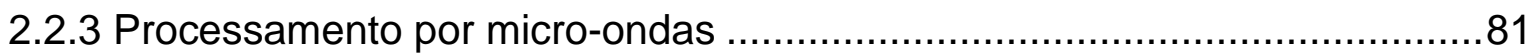

2.2.4 Comparação entre os Diferentes Processamentos....................................84

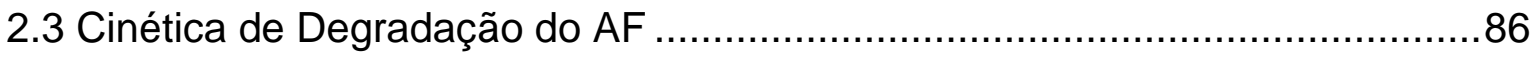

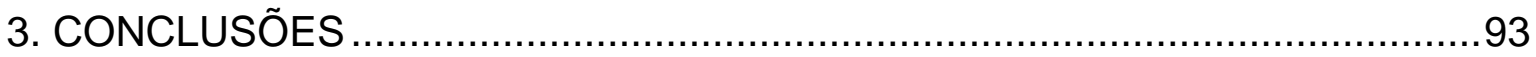

CAPÍTULO 3: DESENVOLVIMENTO DE UM MÉTODO DE EXTRAÇÃO POR SOLVENTE PRESSURIZADO DE ÁCIDO FÓLICO EM FARINHAS DE TRIGO

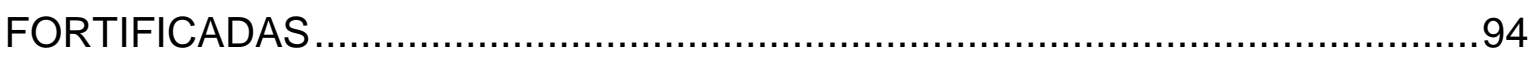

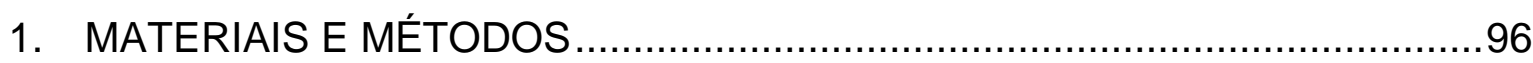

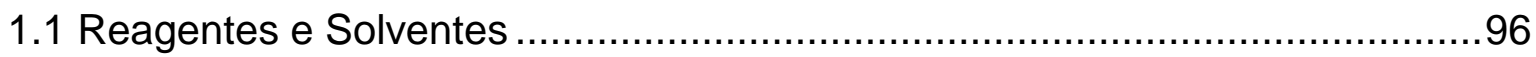

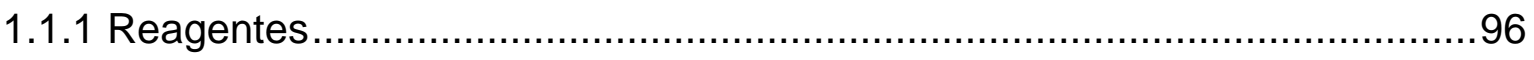

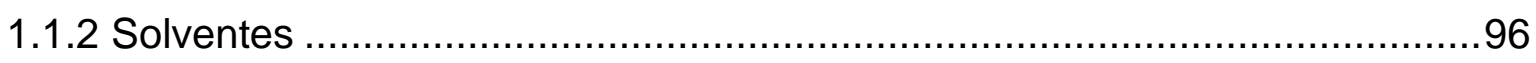

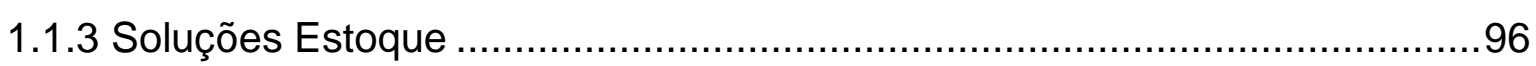

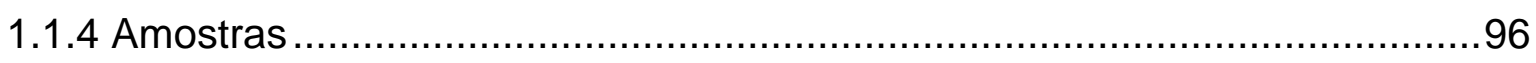

1.2 Preparação in-house de Farinhas de Trigo Fortificadas .................................97

1.3 Extração do Ácido Fólico da Farinha de Trigo Fortificada...............................97

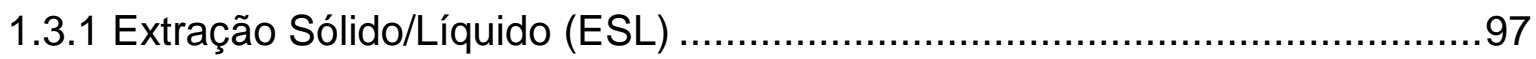

1.3.2 Extração por Solvente Pressurizado (ESP) ............................................98

1.4 Cromatografia Líquida de Alta Eficiência (HPLC) ………...........................98

1.5 Análise Quantitativa de AF em Farinhas de Trigo Fortificadas .......................99

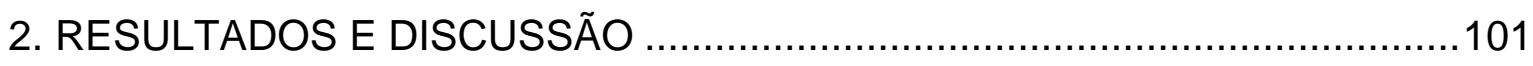

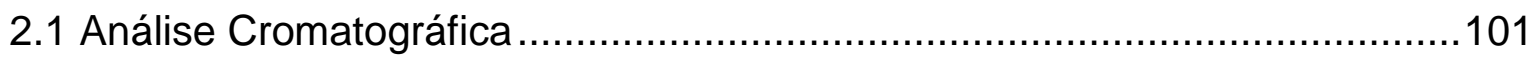

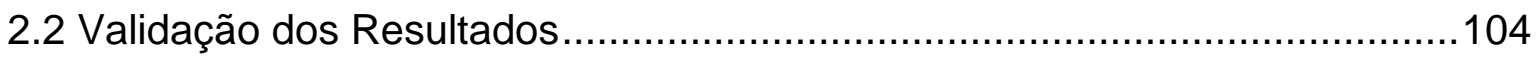

2.3 Otimização da Extração por Solvente Pressurizado (ESP)..........................104

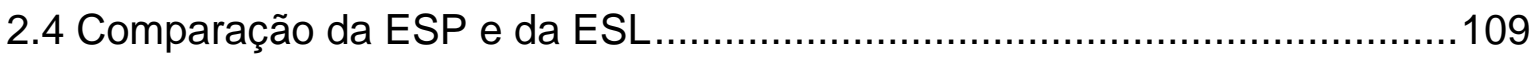

2.5 Quantificação do AF em Farinhas de Trigo Fortificadas Comerciais ............113

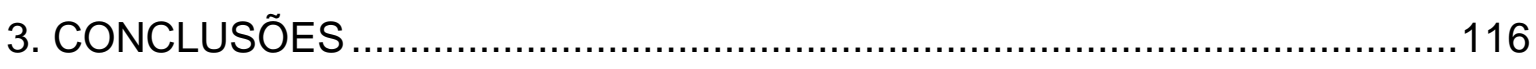


CAPÍTULO 4: QUANTIFICAÇÃO DO ÁCIDO FÓLICO EM FARINHAS DE TRIGO FORTIFICADAS IRRADIADAS E EM PÃES PRODUZIDOS COM FARINHAS DE TRIGO FORTIFICADAS IRRADIADAS......................................................117

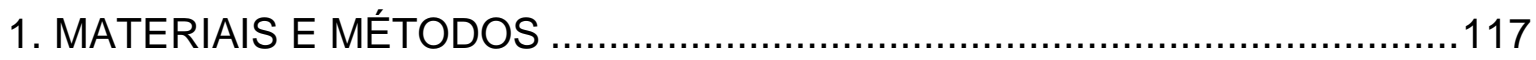

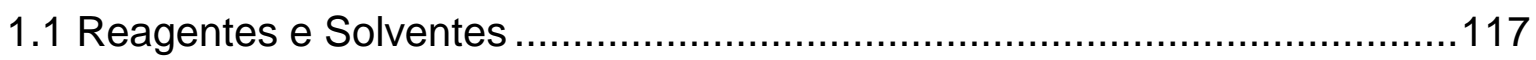

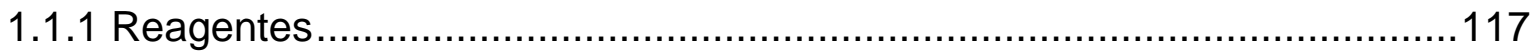

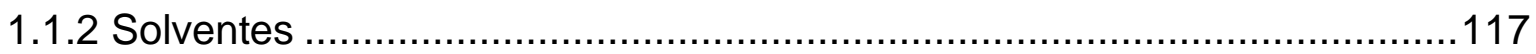

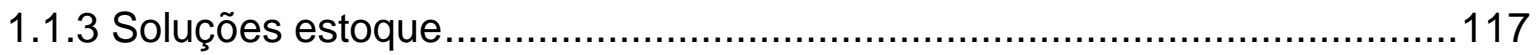

1.2 Preparação in-house de farinhas de trigo fortificadas ................................118

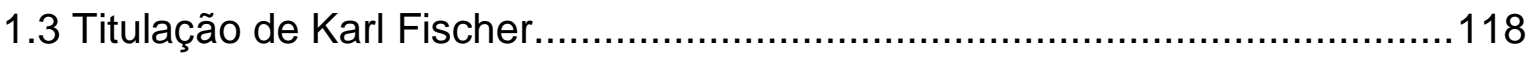

1.4 Processamento por Radiação lonizante ……………............................118

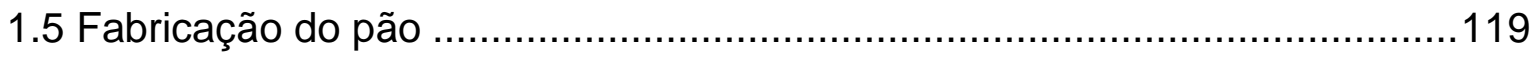

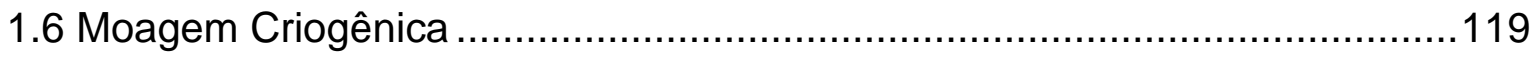

1.7 Extração do AF de amostras de Farinha de Trigo Fortificada e de Pães......120

1.7.1 Extração Sólido/Líquido (ESL) …………………..............................120

1.7.2 Extração por Solvente Pressurizado (ESP) ...........................................120

1.8 Cromatografia Líquida de Alta Eficiência (HPLC) ….................................121

1.8.1 Análise Quantitativa de AF em farinhas de trigo fortificadas .....................121

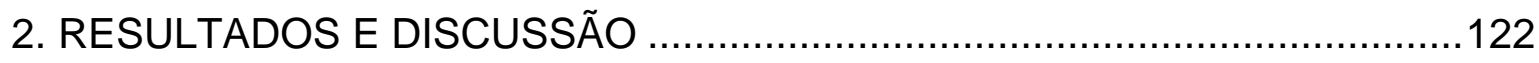

2.1 Efeito do processamento por Radiação lonizante em amostras de AF em pó e em amostras de farinhas de trigo fortificadas com AF .....................................122

2.3 Quantificação do AF em Pães Fabricados com Farinha de Trigo Fortificada

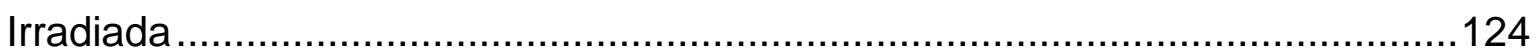

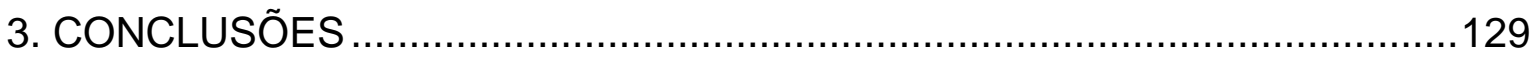

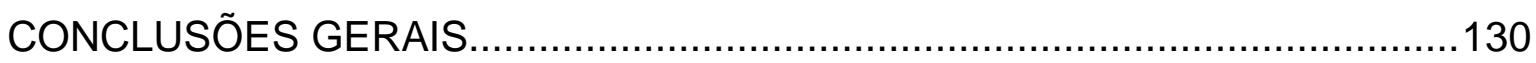

PUBLICAÇÕES.......................................................Erro! Indicador não definido.

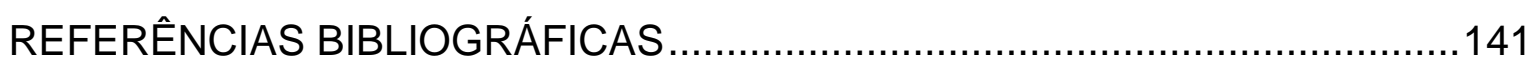




\section{LISTA DE TABELAS}

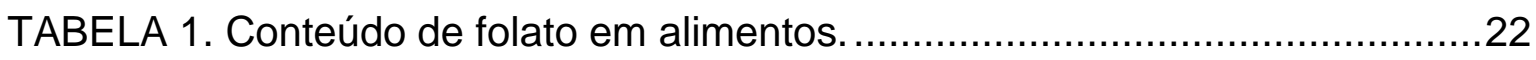

TABELA 2. Gradiente de eluição em cromatografia analítica (Método 1) ..............36

TABELA 3. Gradiente de eluição em cromatografia analítica (Método 2) ..............37

TABELA 4. Gradiente de eluição em cromatografia analítica (Método 3) ..............39

TABELA 5. Gradiente de eluição em cromatografia analítica (Método 4) ..............40

TABELA 6. Valores de $D_{50}$ (kGy) de soluções aquosas de AF a pH 6,8; 8,0 e 12,0

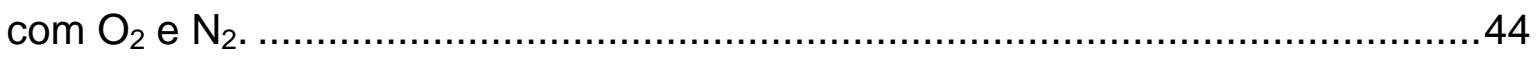

TABELA 7. Valores de temperatura e pressão máximos do processamento por micro-ondas.

TABELA 8. Produtos de degradação do AF decorrentes do processamento por radiação e seus correspondentes tr, m/z (MS), m/z (HRMS) e fórmula molecular.

TABELA 9. Produtos de degradação decorrentes do tratamento térmico do AF e seus correspondentes $\mathrm{tr}, \mathrm{m} / \mathrm{z}$ (MS) e fórmula molecular.

TABELA 10. Produtos de degradação decorrentes do processamento por microondas do $\mathrm{AF}$ e seus correspondentes $\mathrm{tr}, \mathrm{m} / \mathrm{z}$ (MS) e fórmula molecular. .84

TABELA 11. Gradiente de eluição em cromatografia analítica (Método 5) 99 TABELA 12 - Valores de rendimento do AF extraído por ESP e ESL de farinhas de trigo fortificadas de referência. 110

TABELA 13 - Conteúdo de AF extraída por ESP e ESL de seis diferentes farinhas de trigo fortificadas comerciais analisadas por HPLC. 


\section{LISTA DE FIGURAS}

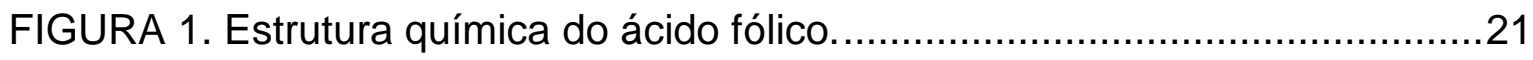

FIGURA 2. Espectro de absorção UV do ácido fólico.......................................21

FIGURA 3. Radura: símbolo utilizado para identificar produtos irradiados. ...........31

FIGURA 4. Porcentagem remanescente de AF em solução aquosa sob diferentes valores de $\mathrm{pH} \operatorname{com}(\mathrm{A}) \mathrm{O}_{2}$ e (B) $\mathrm{N}_{2}$ (-, pH 12,0; … pH 8,0; - - -, pH 6,8) ..........43 FIGURA 5. Efeito do processamento por radiação ionizante na degradação de solução de $A F(\mathrm{pH} 8,0)$. 46

FIGURA 6. Degradação do AF decorrente do aquecimento em estufa $\left(200^{\circ} \mathrm{C}\right)$...48 FIGURA 7. Degradação do AF decorrente do aquecimento em forno micro-ondas

FIGURA 8. Sobreposição de perfis cromatográficos de soluções de AF $(0,1$ $\mathrm{mg} / \mathrm{mL}$ ) não-irradiada (A) e irradiadas com 1 kGy (B), 5 kGy (C) e 10 kGy (D)....53 FIGURA 9. Estrutura química e espectro UV do PCA (linha pontilhada) sobreposto ao produto de degradação eluído com $\mathrm{tr}=13,2 \mathrm{~min}$ (linha contínua). .54 FIGURA 10. Espectro de massas $\left(\mathrm{ESI}^{+}\right)$do produto de degradação eluído com $\operatorname{tr}=13,2 \mathrm{~min}$. .55

FIGURA 11. Espectro de massas em sequência $\left(\mathrm{MS}^{2}-\mathrm{ESI}^{+}\right)$do produto de degradação eluído com $\operatorname{tr}=13,2$ min. 56

FIGURA 12. Espectro de massas HRMS $\left(\mathrm{ESI}^{+}\right)$do produto de degradação eluído com $\operatorname{tr}=13,2 \mathrm{~min}$.

FIGURA 13. Estrutura química e espectro UV do pABGA (linha pontilhada) sobreposto ao produto de degradação eluído com $\operatorname{tr}=17,2 \mathrm{~min}$ (linha contínua).58 FIGURA 14. Espectro de massas $\left(\mathrm{ESI}^{+}\right)$do produto de degradação eluído com tr $=17,2 \mathrm{~min}$. .59

FIGURA 15. Espectro de massas em sequência $\left(\mathrm{MS}^{2}-\mathrm{ESI}^{+}\right)$do produto de degradação eluído com $\operatorname{tr}=17,2 \mathrm{~min}$.

FIGURA 16. Espectro de massas HRMS $\left(\mathrm{ESI}^{+}\right)$do produto de degradação eluído com $\operatorname{tr}=17,2 \mathrm{~min}$. .61

FIGURA 17. Espectro de massas $\left(E S I^{+}\right)$do PABA $[\mathrm{M}+\mathrm{H}]^{+}$.

FIGURA 18. Estrutura química e espectro UV do PABA. 62

FIGURA 19. Espectro de massas HRMS $\left(\mathrm{ESI}^{+}\right)$do PABA $[\mathrm{M}+\mathrm{H}]^{+}$. 
FIGURA 20. Espectro de massas $\left(\mathrm{ESI}^{+}\right)$do produto de degradação eluído com $\operatorname{tr}=6,9 \mathrm{~min}$.

FIGURA 21. Espectro de massas em sequência $\left(\mathrm{MS}^{2}-\mathrm{ESI}^{+}\right)$do produto de degradação eluído com $\operatorname{tr}=6,9$ min.

FIGURA 22. Espectro de massas HRMS $\left(\mathrm{ESI}^{+}\right)$do produto de degradação eluído com $\operatorname{tr}=6,9 \mathrm{~min}$.

FIGURA 23. Estrutura química e espectro UV do XA (linha pontilhada) sobreposto ao produto de degradação eluído com $\mathrm{tr}=6,9 \mathrm{~min}$ (linha contínua).

FIGURA 24. Espectro de massas $\left(\mathrm{ESI}^{+}\right)$do produto de degradação eluído com $\operatorname{tr}=8,7 \mathrm{~min}$.

FIGURA 25. Espectro de massas em sequência $\left(\mathrm{MS}^{2}-\mathrm{ESI}^{+}\right)$do produto de degradação eluído com $\operatorname{tr}=8,7$ min. 68

FIGURA 26. Espectro de massas HRMS $\left(\mathrm{ESI}^{+}\right)$do produto de degradação eluído com $\operatorname{tr}=8,7 \mathrm{~min}$.

FIGURA 27. Estrutura química e espectro UV do AHMP (linha pontilhada) sobreposto ao produto de degradação eluído com $\operatorname{tr}=8,7$ min (linha contínua). . 69 FIGURA 28. Espectro de massas $\left(\mathrm{ESI}^{+}\right)$do produto de degradação eluído a $45,8 \mathrm{~min}$ .70

FIGURA 29. Espectro de massas em sequência $\left(\mathrm{MS}^{2}-\mathrm{ESI}^{+}\right)$do produto de degradação eluído com $\operatorname{tr}=45,8$ min. .71

FIGURA 30. Espectro de massas HRMS $\left(\mathrm{ESI}^{+}\right)$do produto de degradação eluído a $45,8 \mathrm{~min}$. .72

FIGURA 31. Estrutura química e espectro UV do pNBGA. .72 FIGURA 32. Espectro de massas (MS-ESI ${ }^{+}$) do produto de degradação eluído com $\mathrm{tr}=38,5 \mathrm{~min}$. .73 FIGURA 33. Espectro de massas HRMS $\left(\mathrm{ESI}^{+}\right)$do produto de degradação eluído a $38,5 \mathrm{~min}$. .74

FIGURA 34. Espectro de massas (MS-ESI+) do produto de degradação eluído com $\operatorname{tr}=40,5 \mathrm{~min}$. .75

FIGURA 35. Espectro de massas HRMS $\left(\mathrm{ESI}^{+}\right)$do produto de degradação eluído a $40,5 \mathrm{~min}$. .76

FIGURA 36. Perfis cromatográficos sobrepostos de soluções $(0,1 \mathrm{mg} / \mathrm{mL})$ preparadas com $\mathrm{AF}$ em pó controle (A) e AF em pó aquecido em estufa durante $15 \mathrm{~min}(\mathrm{~B}), 30 \mathrm{~min}(\mathrm{C}), 45 \mathrm{~min}(\mathrm{D}), 60 \mathrm{~min}(\mathrm{E}), 120 \mathrm{~min}(\mathrm{~F})$ e $180 \mathrm{~min}(\mathrm{G})$ .77 
FIGURA 37. Estrutura química, espectro de absorção UV e espectro de massas $\left(\mathrm{ESI}^{+}\right)$do PA $[\mathrm{M}+\mathrm{H}]^{+}$

FIGURA 38. Perfis cromatográficos sobrepostos de soluções $(0,1 \mathrm{mg} / \mathrm{mL})$ controle (A) e processadas em micro-ondas durante $10 \mathrm{~min}$ (B), $15 \mathrm{~min}$ (C), $20 \mathrm{~min}$ (D) e $25 \min (\mathrm{E})$

FIGURA 39. Cinética de degradação do AF por irradiação e formação de produtos de degradação (concentração de $A F$ representado na escala à direita). .87 FIGURA 40. Esquema proposto para a radiodegradação do AF. 88 FIGURA 41. Cinética de degradação do AF por aquecimento em estufa e formação de produtos de degradação (concentração de AF representado na escala à direita). .89

FIGURA 42. Esquema proposto para a termodegradação do AF. 90 FIGURA 43. Cinética de degradação do AF por aquecimento em forno microondas e formação de produtos de degradação (concentração de AF representado na escala à direita) 91

FIGURA 44. Esquema proposto para a degradação do AF por micro-ondas. ..... 92 FIGURA 45 - Perfil cromatográfico de soluções padrão de (A) AF e TP, (B) extrato de farinha de trigo não fortificada sem padrão interno, (B1) zoom do perfil cromatográfico de $\mathrm{B}$ compreendendo os tempos de retenção do $\mathrm{AF}$ e TP e (C) extrato de farinha de trigo fortificada com adição do padrão interno TP. 103 FIGURA 46 - Porcentagem de recuperação do AF após a otimização da ESP. 107 FIGURA 47. Estrutura química e espectro UV do AF (A) versus estrutura química e espectro UV da TP. 108 FIGURA 48 - Conteúdo de AF recuperado de extrações sucessivas de farinhas de trigo fortificadas in house: (A) método ESP; (B) método ESL. FIGURA 49 - Correlação do conteúdo de AF extraído de farinhas de trigo comerciais pelo método ESP e ESL.

FIGURA 50 - Porcentagem de recuperação do AF de amostras de farinhas de trigo processadas por feixe de elétrons.

FIGURA 51 - Porcentagem de recuperação do AF de amostras de farinhas de trigo irradiadas e pães preparados com farinha de trigo irradiada. 125 FIGURA 52. Comparação dos resultados de porcentagem de recuperação do AF de amostras de farinha de trigo fortificada e de pão preparado com farinha de trigo fortificada. 
FIGURA 53 - Efeito do aquecimento do AF em pó dentro da cuba da máquina de pão: $A F$ controle (A); $A F$ aquecido por 48 min (B); zoom do cromatrograma $B(C)$; zoom de cromatograma de pABGA (D)..................................................127 


\section{LISTA DE ABREVIATURAS, SIGLAS E SÍMBOLOS}

ACN: acetonitrila

AF: ácido fólico

AHMP: 2-amino-6-(hidroximetil)pteridina-4(1H)-one

DAD: detector por rede de diodos

$D_{50}$ : dose efetiva

DFE: ingestão diária recomendada para o folato

ESI: ionização por eletrospray

ESL: extração sólido-líquida

ESP: extração por solvente pressurizado

HPLC: cromatografia líquida de alta eficiência

HRMS: espectrômetro de massas de alta resolução

LC/MS/MS: cromatografia líquida acoplada à espectrometria de massas em sequência

$M S^{2}$ : espectrometria de massas em sequência

$\mathrm{m} / \mathrm{z}$ : relação massa/carga

$\mathrm{MeOH}$ : metanol

$\mathrm{NaOH}$ : hidróxido de sódio

PA: ácido pteróico

PABA: ácido $p$-aminobenzóico

pABGA: $p$-aminobenzoil-L-ácido glutâmico

PCA: 6-carboxipterina

pNBGA: N-(4-nitrobenzoil)-L-ácido glutâmico hemihidratado

Q-TOF: quadrupolo time-of-flight

RP-HPLC: cromatografia líquida de alta eficiência em fase reversa

tr: tempo de retenção

UL: limite superior tolerável de ingestão

UV/Vis: ultravioleta/visível

XA: xantopterina 


\section{INTRODUÇÃO}

As vitaminas são um grupo de compostos orgânicos, constituintes minoritários dos alimentos, essenciais para o desenvolvimento normal, para a manutenção da saúde e de funções metabólicas do organismo humano. Estes micronutrientes são divididos em dois grupos de acordo com sua solubilidade: vitaminas lipossolúveis (A, D, E, K) e vitaminas hidrossolúveis (C, B1, B2, niacina, B5, B6, biotina, ácido fólico e B12) (Ball, 2006).

Neste sentido, o ácido fólico tem ganhado espaço nos últimos anos em função de fortes evidências que relacionam sua ingestão inadequada com severas desordens de saúde, como doenças cardiovasculares (Moat et al., 2004), desordens neuropsiquiátricas (Selhub et al., 2000), defeitos do tubo neural (Tamura et al., 2006) e alguns tipos de câncer (Kim, 1997).

A preocupação sobre a condição nutricional das populações e o aproveitamento adequado das fontes naturais de alimentos tem crescido nos últimos anos (Penteado, 2003). Nos países em desenvolvimento os problemas sociais têm uma influência direta na alimentação da população em geral e casos de má-nutrição podem atingir todas as faixas etárias. Logo, além de medidas para a erradicação da mortalidade infantil faz-se necessária a garantia de um desenvolvimento saudável do feto durante a gestação.

Assim, medidas governamentais de fortificação compulsória de alimentos com vitaminas têm sido implantadas em diversos países para garantir um suprimento adequado de ácido fólico na alimentação. Seguindo estas recomendações, a Agência Nacional de Vigilância Sanitária (Brasil, 2002) determinou a fortificação compulsória de farinhas de trigo e milho com AF em uma dose de $1,50 \mu \mathrm{g} / \mathrm{g}$ de farinha de trigo e milho.

O entendimento sobre o manuseio dos alimentos, o tempo de estocagem, o pré/pós-processamento de alimentos e a preparação para o consumo são importantes já que podem levar à perda das vitaminas mais instáveis e, muitas vezes a biodisponibilidade das vitaminas remanescentes também é reduzida. Assim o conhecimento sobre a estabilidade das vitaminas é fundamental para assegurar à população a ingestão adequada de cada vitamina (Penteado, 2003; Ball, 2006). 
Com base nisso, a indústria de alimentos tem interesse em conhecer o efeito das diferentes etapas de produção na composição final dos alimentos, para atender critérios internos de qualidade e cumprir com a legislação referente a cada produto. Assim, torna-se necessário o desenvolvimento e validação de métodos analíticos para a extração e determinação do conteúdo de vitaminas em alimentos fortificados e para a compreensão de eventuais perdas durante 0 processamento e a vida de prateleira do produto. Isto assegura ao consumidor final as expectativas de adequação nutricional e inocuidade do alimento.

Desta maneira, este trabalho foi dividido em quatro capítulos. primeiro capítulo apresenta o contexto do estudo sobre o ácido fólico, sua estrutura e propriedades, as fontes naturais de folatos, seu metabolismo e biodisponibilidade, os efeitos de uma carência em folatos, a fortificação de alimentos com ácido fólico bem como sua estabilidade. Também é abordado o pré-processamento por radiação ionizante, seus conceitos, objetivos e modo de ação nos alimentos e pós-processamentos como o tratamento térmico e microondas. O segundo capítulo apresenta o efeito dos processamentos por radiação ionizante, por aquecimento em forno e por aquecimento em micro-ondas na degradação do ácido fólico sob diferentes condições de solubilização e de pH. Também são elucidados e identificados os produtos de degradação do ácido fólico formados após cada tratamento. No terceiro capítulo foi descrito o desenvolvimento de um método de extração por solvente pressurizado do ácido fólico de farinha de trigo fortificada. O quarto capítulo avaliou o efeito do processo de irradiação e panificação no teor de AF de farinha de trigo fortificada e pães, aplicando o método de extração por solvente pressurizado. 


\section{OBJETIVOS}

Os objetivos do presente trabalho foram investigar os efeitos do processamento por ionização, calor e micro-ondas na degradação do ácido fólico. Para isso foi utilizado o ácido fólico em pó, em solução aquosa e em suspensão como modelo teórico e farinha de trigo fortificada com ácido fólico como alimentomodelo para o conhecimento dos mecanismos de degradação. Para alcançar este objetivo o trabalho compreendeu as seguintes etapas:

- avaliação do efeito dos processamentos de ionização, calor e microondas na degradação do ácido fólico em pó, em solução e em suspensão;

- identificação e quantificação dos produtos de degradação majoritários do ácido fólico em pó, em solução e em suspensão decorrentes de cada processamento;

- desenvolvimento de um método de extração por solvente pressurizado do ácido fólico de farinha de trigo fortificada;

- quantificação do ácido fólico de farinha de trigo fortificada, processadas ou não por radiação;

- avaliação do efeito do processo de panificação no teor de ácido fólico. 


\section{CAPÍTULO 1: CONTEXTO DO ESTUDO}

\section{1 Ácido Fólico}

\subsubsection{Estrutura e Definição}

O ácido fólico $(\mathrm{AF})$ ou ácido pteroil-L-glutâmico, também conhecido como vitamina $\mathrm{B} 9$, é uma vitamina hidrossolúvel pertencente ao grupo de vitaminas do complexo B. O termo ácido fólico é geralmente utilizado para designar os folatos, embora represente somente uma pequena porcentagem dos folatos que ocorrem naturalmente (Gregory, 1989).

Os folatos de ocorrência natural diferem na composição da sua cadeia lateral com relação ao número de glutamatos, assim como a posição específica de ligação de estruturas de carbono na vitamina. Estes folatos são derivados do tetra-hidrofolato (THF), que é a forma totalmente reduzida. Assim a forma sintética do folato, o $\mathrm{AF}$ se refere especificamente ao monoglutamato completamente oxidado (Bailey, 2007).

O AF é um pó de coloração laranja-amarelado, micro-cristalino, quase sem odor e sabor. Apresenta um peso molecular de $441,4 \mathrm{~g} / \mathrm{mol}\left(\mathrm{C}_{19} \mathrm{H}_{19} \mathrm{~N}_{7} \mathrm{O}_{6}\right)$. $\mathrm{O}$ $\mathrm{AF}$ não tem um ponto de fusão definido, embora escureça a $250^{\circ} \mathrm{C}$ seguido a uma carbonização. É composto de uma pterina (2-amino-4-hidroxipteridina), do ácido p-aminobenzóico (PABA) e do ácido glutâmico (FIG. 1). Separadamente, as três frações não têm atividade vitamínica. Seu espectro de absorção UV está representado na FIG. 2 (Lucock, 2000; Ball, 2006). 


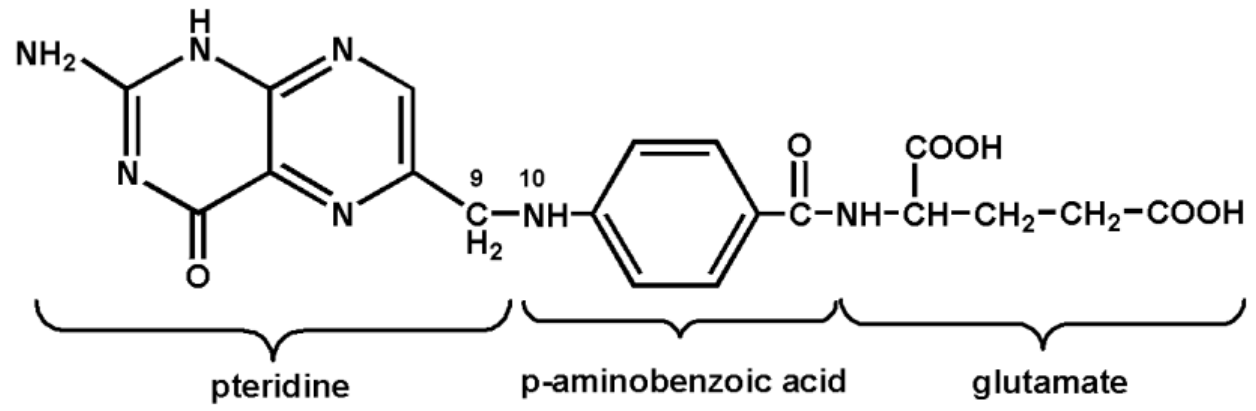

FIGURA 1. Estrutura química do ácido fólico.

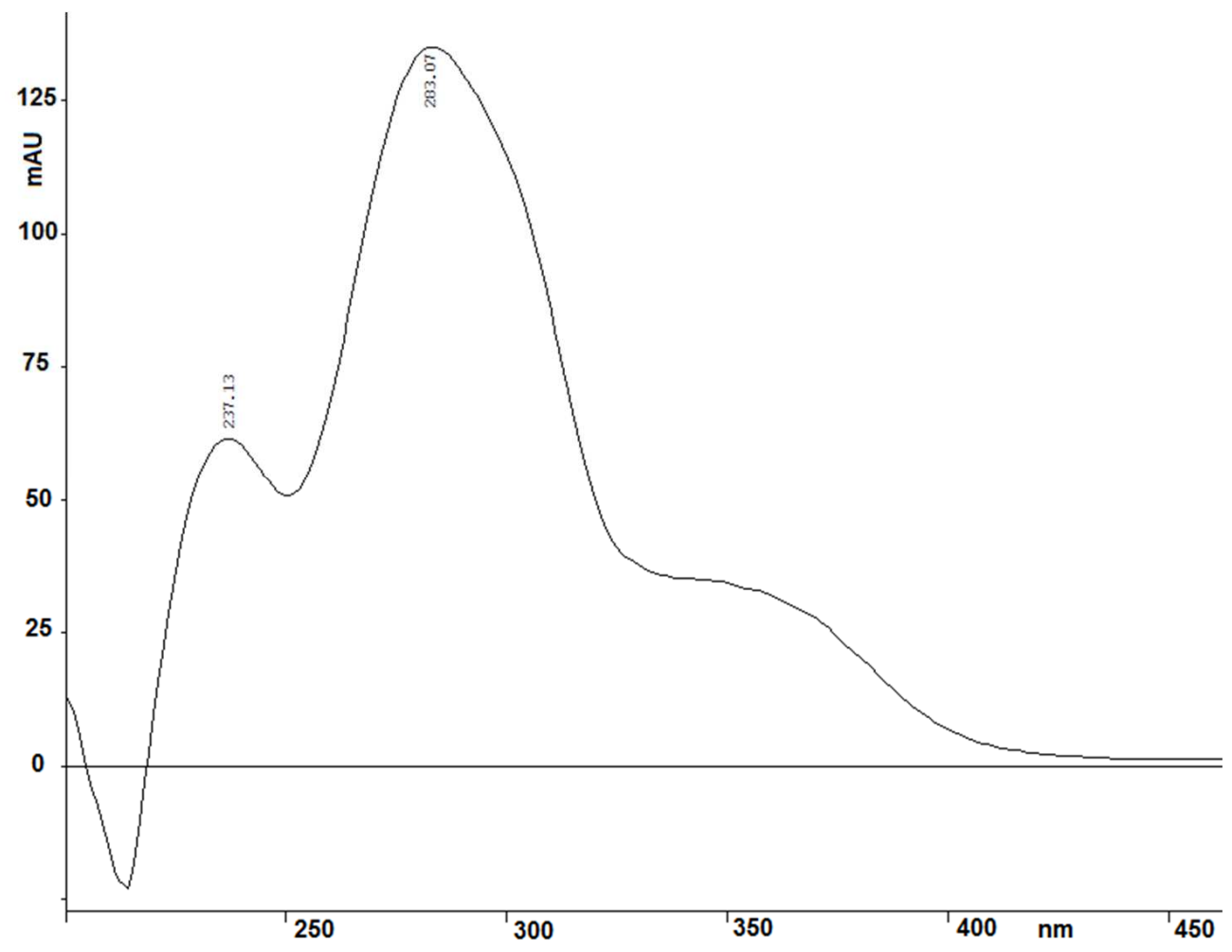

FIGURA 2. Espectro de absorção UV do ácido fólico.

Ele se mostra praticamente insolúvel em água em $\mathrm{pH}$ neutro $(0,01 \mathrm{mg} / \mathrm{mL})$. Igualmente apresenta uma baixa solubilidade em metanol, é insolúvel em acetona, di-etil éter, clorofórmio e benzeno. Esta vitamina só é solúvel e estável em soluções diluídas alcalinas e igualmente se dissolve em meio 
ácido, porém nesta condição é instável. Sua dissolução também é facilitada na presença de sais (Ball, 2006; Guilland, 2009).

\subsubsection{Fontes Naturais de Folatos}

Os humanos não sintetizam folatos e devem adquiri-los por meio dos alimentos (Lucock, 2000). Geralmente frutas e carne, exceto vísceras, são fontes pobres de folatos. As principais fontes de folatos em alimentos são verduras, especialmente vegetais de folhas verdes como alface, couve e brócolis. Outras fontes de folatos são lentilhas, laranja, tomate, cebola, pimenta, feijão branco, aspargos, gérmen de trigo e amendoim (TAB. 1) (Vahteristo et al., 1997).

TABELA 1. Conteúdo de folato em alimentos.

\section{Concentração de folato $(\mu \mathrm{g} / 100 \mathrm{~g}$ peso fresco)}

\begin{tabular}{rccc}
\hline \multicolumn{1}{c}{ Produto } & 5-metil-THF & THF & Total (como AF) \\
\hline Vegetais & 21 & 3 & 23 \\
cenoura crua & 16 & 1 & 16 \\
brócolis & 98 & 18 & 114 \\
couve-de-bruxelas & 88 & 9 & 94 \\
couve-flor & 80 & 9 & 85 \\
nabo & 50 & 2 & 49 \\
tomate & 11 & 1 & 11 \\
cebola & 13 & 1 & 13 \\
pimenta-vermelha & 50 & 5 & 55 \\
alface & 44 & 9 & 51 \\
Frutas & 51 & 10 & 59 \\
bantilha congelada & & & 13 \\
suco de laranja & 16 & $<1$ & 27 \\
\hline laranja & 12 & $<1$ & 15 \\
\hline
\end{tabular}

Fonte: Adaptado de Vahteristo et al. (1997). 


\subsubsection{Metabolismo e Biodisponibilidade}

O folato atua como coenzima, em processos de redução e de transformação de unidades de carbono, incluindo nucleotídeos e certos aminoácidos (Lucock, 2000).

A ingestão adequada de folato é vital para a divisão celular e para a homeostase devido ao papel essencial das folato-coenzimas na síntese do ácido nucléico, na formação de metionina e, na liberação, oxidação e redução de unidades de carbono necessárias para o metabolismo normal (Penteado, 2003).

Os folatos são absorvidos no intestino delgado e transportados pelo sangue, sendo então estocados em pequena quantidade (5 a $10 \mathrm{mg}$ ) principalmente no fígado. O suprimento de folato-coenzima in vivo depende da quantidade e da biodisponibilidade do folato ingerido e da taxa de perda pela urina e pelas fezes e através do catabolismo. Isto demonstra a importância de uma ingestão regular de AF na alimentação (Guilland, 2009).

A biodisponibilidade do AF e dos folatos naturais é definida como a fração da vitamina que é absorvida fisiologicamente e utilizada pelo organismo. A biodisponibilidade pode ser influenciada por muitos fatores, incluindo a forma química do folato, a matriz alimentícia, o ambiente químico no trato intestinal e fatores que podem afetar a utilização metabólica do folato pós-absorção (McNulty \& Pentieva, 2004, 2009).

Os derivados poliglutamatos constituem a maioria dos folatos presentes nos alimentos e nos meios biológicos. A absorção de folatos se dá no duodeno e jejuno, após a hidrólise dos poliglutamatos em monoglutamatos. Transportadores intestinais facilitam sua passagem neste nível. Uma vez dentro do enterócito, os monoglutamatos são metabolizados e ocorre uma dupla redução do AF (Guilland, 2009).

Após a metilação, principalmente em 5-metil-THF, o sangue encaminha os folatos sob a forma metabolizada em direção ao fígado. Nele se encontra $50 \%$ do estoque do organismo: 5 a $10 \mathrm{mg}$. O resto encontra-se dentro dos eritrócitos: 535 a $935 \mathrm{nmol} / \mathrm{L}$, assegurando assim um nível sérico de em média 10 a 30 nmol/L. A liberação progressiva do estoque hepático permite manter um nível sérico mínimo no caso de uma carência durante no máximo um mês (Guilland, 2009). 


\subsubsection{Ingestão Diária Recomendada}

A ingestão diária recomendada para o folato (DFE) é uma maneira comum de expressar os folatos totais oriundos dos folatos naturais e do AF sintético. A quantidade do AF sintético é multiplicada por 1,7, e esta quantidade é adicionada aos microgramas do folato natural. O fator de conversão $(1,7)$ está baseado na observação de que quando o AF é consumido com um alimento, ele é biodisponível em 85\% (Pfeiffer et al., 1997), enquanto que os folatos naturais são biodisponíveis em aproximadamente 50\% (Sauberlich et al., 1987); assim, a razão 85/50 é igual a um fator multiplicador de 1,7 no cálculo do DFE.

A ingestão dietética de referência para folatos determinada em estudos metabólicos da concentração da vitamina nos eritrócitos é considerada o maior indicador de adequação. Os valores são de $400 \mu \mathrm{g} /$ dia de equivalentes de folato dietético (DFE) para adultos de 19 anos e inclui um aporte adicional de 100 a 200 $\mu \mathrm{g}$ de DFE/dia para lactantes e grávidas, respectivamente (Penteado, 2003).

Quando a ingestão de folatos excede o limite fisiológico específico, a habilidade das enzimas intestinais e hepáticas em converter a vitamina para a forma reduzida é sobrecarregada, resultando em AF não metabolizado na circulação sanguínea (Bailey, 2007).

O limite fisiológico está intimamente relacionado ao limite superior tolerável de ingestão (UL), que é o nível máximo de ingestão diária de nutrientes que provavelmente não apresentaria um risco de efeitos adversos para quase todas as pessoas. Indivíduos de uma população em geral não devem consumir rotineiramente mais do que o UL. O UL para os folatos em alimentos fortificados e/ou suplementos alimentícios é de $1.000 \mu \mathrm{g} / \mathrm{dia}$. Ainda que um indivíduo consuma alimentos fortificados e faça uso concomitantemente de um suplemento de AF não atingiria este limite. O UL não inclui os folatos de ocorrência natural e está baseado no aparecimento ou exacerbação de neuropatia em indivíduos com deficiência de vitamina B12. É sabido que uma ingestão excessiva de suplementos de AF pode ocultar ou mascarar e assim comprometer o diagnóstico de deficiência de vitamina B12 (Otten et al., 2006). 


\subsubsection{Deficiência de folatos}

No caso de deficiência de folato, todas as reações do metabolismo do carbono podem ser comprometidas em vários graus dependendo das afinidades relativas das enzimas às respectivas moléculas de folato envolvidas (Penteado, 2003).

Desta forma, os folatos estão atraindo um considerável interesse na área de nutrição devido às crescentes evidências que apontam a relação de uma ingestão inadequada de folatos com severas desordens de saúde, como defeitos do tubo neural (Tamura et al., 2006), doenças cardiovasculares (Moat et al., 2004), desordens neuropsiquiátricas (Selhub et al., 2000) e alguns tipos de câncer (Kim, 1997).

A carência de AF pode se manifestar por um distúrbio nas células que se renovam rapidamente, notavelmente à nível hematopoiético. Logo, a deficiência de AF pode se traduzir por uma anemia megaloblástica e uma diminuição da contagem de leucócitos e plaquetas. A renovação das células constituintes do trato digestivo se vê também reduzida, causando problemas de digestão e dores gástricas, que impedem uma nutrição normal (Guilland, 2009)

Igualmente, uma carência em folatos ocasiona a ausência ou reparação ineficiente do DNA durante a divisão celular. Se estes erros de replicação ocorrerem em genes importantes, tais como os proto-oncogenes ou os genes supressores de tumores, pode haver 0 desenvolvimento de câncer (Guilland, 2009).

Vale ressaltar o papel primordial do AF nas mulheres grávidas. Foi estabelecido que os folatos têm um papel fundamental na prevenção de problemas de desenvolvimento, podendo ocorrer severas mal-formações congênitas do tubo neural do feto (spina bifida). A medula espinhal e o sistema nervoso são danificados de maneira permanente e em diferentes níveis, podendo resultar em paralisias definitivas. Estas paralisias variam na sua extensão segundo o local e gravidade da lesão e segundo o tipo de spina bifida. Os sintomas variam de incontinência urinária até uma paralisia parcial ou total dos membros inferiores (Mitchell et al., 2004).

A dose ótima recomendada de folato necessária para obter proteção contra a má-formação do tubo neural é de $400 \mu \mathrm{g} /$ dia. Este nível de ingestão deve 
ser garantido no momento da concepção e imediatamente depois, período em que as mulheres não estão cientes da gravidez (Penteado, 2003).

Para erradicar estes problemas e, fundamentalmente erradicar a incidência de má-formação do tubo neural, três estratégias podem ser consideradas: utilização de suplementos de AF, seleção de alimentos ricos em folato e consumo de alimentos fortificados. Entretanto, a eficiência da utilização das duas primeiras medidas é discutida em países subdesenvolvidos e em desenvolvimento que sofrem de importantes problemas sociais e de má-nutrição. Neste sentido, uma intervenção como a fortificação de alimentos pode resultar em uma mudança positiva do quadro de deficiência de folato.

\subsubsection{Fortificação de Alimentos com Ácido Fólico}

A forma sintética do AF apresenta vantagens em relação aos folatos de ocorrência natural para fins de fortificação. Isto se deve, notavelmente em função de sua alta estabilidade e disponibilidade que contam para sua ampla distribuição na fortificação de alimentos e preparação de suplementos vitamínicos. Na forma sintética, o anel pterina (2-amino-4-hidroxipteridina) não se encontra reduzido, promovendo assim uma melhor resistência à oxidação química (Gregory, 1989; Bailey \& Gregory, 1999; McNulty \& Pentieva, 2004).

A fim de atingir diferentes segmentos da população que pode ter diferentes hábitos alimentares, a seleção de mais de um alimento-carreador pode ser necessário. Os cereais são em geral bons alimentos carreadores devido ao fato de serem versáteis, saborosos, de fácil disponibilidade no mercado, acessíveis e aceitos culturalmente. Eles são consumidos diariamente, e em quase todas as refeições, por um grande grupo de pessoas incluindo crianças. Além disso, não há restrições religiosas ou culturais do seu consumo. Os principais benefícios da fortificação são: alta aceitabilidade, não requerer mudanças nos hábitos alimentares, não alterar as características do alimento, podem ser introduzidas rapidamente e produzir benefícios para a população alvo de forma rápida e é segura (WHO, 2006).

As vitaminas do complexo $\mathrm{B}$, incluindo o $\mathrm{AF}$, podem ser adicionadas diretamente na farinha de trigo como um só ingrediente ou como uma pré-mistura (que geralmente também contem ferro), ou são diluídas com uma pequena 
quantidade de farinha no moinho antes de serem acrescentadas ao lote. No caso de cereais matinais prontos para o consumo, as vitaminas do complexo B são adicionadas à mistura seca antes do processo de extrusão ou outros processos, ou uma solução ou suspensão pode ser pulverizada sobre os cereais depois de torrados (WHO, 2006).

Medidas compulsórias de fortificação atualmente são adotadas em diversos países. Desde janeiro de 1998, o FDA determinou que todas as farinhas e grãos de cereais não cozidos nos EUA deveriam ser fortificados com uma concentração de $140 \mu \mathrm{g}$ de AF por 100 gramas do produto. Estima-se que esta medida aumentaria a ingestão diária de folato em $100 \mu \mathrm{g}$ por dia pelas mulheres que normalmente ingerem quantidades pequenas de folato dietético (Penteado, 2003).

Assim como os Estados Unidos, outros 30 países adicionam o AF à farinha, incluindo: Canadá $(150 \mu \mathrm{g} / 100 \mathrm{~g})$, Chile $(220 \mu \mathrm{g} / 100 \mathrm{~g}$ de farinha de trigo), Costa Rica (180 $\mu \mathrm{g} / 100 \mathrm{~g})$, República Dominicana $(180 \mu \mathrm{g} / 100 \mathrm{~g})$, El Salvador $(180 \mu \mathrm{g} / 100 \mathrm{~g})$, Guatemala $(180 \mu \mathrm{g} / 100 \mathrm{~g})$, Honduras $(180 \mu \mathrm{g} / 100 \mathrm{~g})$, Indonésia (200 $\mu \mathrm{g} / 100 \mathrm{~g}$ de farinha de trigo), México $(200 \mu \mathrm{g} / 100 \mathrm{~g}$ de farinha de

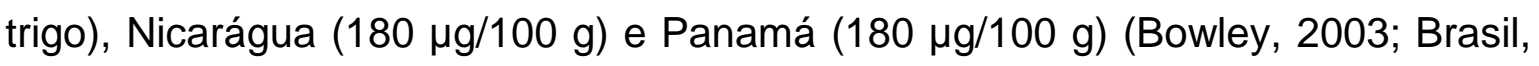
2005).

Seguindo esta recomendação, em 2002, a Agência Nacional de Vigilância Sanitária (Brasil, 2002) determinou a fortificação compulsória com AF e ferro de farinhas de trigo e milho com uma quantidade de $150 \mu \mathrm{g}$ de AF para cada $100 \mathrm{~g}$ de farinha de trigo e milho.

O efeito da fortificação compulsória de farinhas teve um efeito importante na redução da incidência de doenças do tubo neural (DTN). Em um estudo sobre os efeitos da fortificação de farinhas, Crider et al. (2011) constataram que nos Estados Unidos houve uma redução de 19\% a 32\% na prevalência de DTN, desde a fortificação compulsória de 1998. 


\subsubsection{Efeito dos Processamentos de Alimentos na Estabilidade do AF}

O desenvolvimento de novos produtos alimentícios e de novos processamentos de alimentos visa reter tanto quanto possível o conteúdo natural de vitaminas, proteger os micro-nutrientes acrescentados e minimizar 0 surgimento de produtos neo-formados indesejáveis (Ball, 2006).

A labilidade química de todos os folatos naturais resulta em uma perda significante de atividade bioquímica durante as etapas de colheita, processamento, estocagem e preparação. De maneira geral, metade ou até três quartos da atividade biológica inicial do folato é perdida durante estas etapas (Bailey \& Gregory, 1999).

A estabilidade dos folatos durante o processamento de alimentos é influenciada pela temperatura, duração do aquecimento, $\mathrm{pH}$, dose de radiação, presença de oxigênio, luz, íons metálicos, antioxidantes (McKillop et al., 2002; Indrawati et al., 2004; Verlinde et al., 2008; Araújo et al., 2011) ou combinações destes fatores. A degradação desta molécula pode resultar da reação de cisão, como a quebra da ligação covalente C9-N10 que resulta na perda irreversível da atividade vitamínica (Murphy et al., 1976; McKillop et al., 2002).

\section{Processamento térmico}

A temperatura elevada acelera reações que, de outra forma, ocorreriam com mais lentidão à temperatura ambiente. Perdas de vitaminas induzidas termicamente dependem da natureza química dos alimentos, do seu ambiente químico $(\mathrm{pH}$, umidade relativa do ar, metais de transição, outros compostos reativos, concentração de oxigênio dissolvido, etc.), da estabilidade de formas individuais de vitaminas presentes e da possibilidade de lixiviação (Damodaran et al., 2010).

O tratamento térmico é uma parte intrínseca da maioria dos processamentos de alimentos e pode ser empregado para inativar enzimas e fatores tóxicos (como as lectinas), para alterar a textura e o sabor ou para preservar (Ryley \& Kajda, 1994).

Provavelmente o fator mais importante em qualquer processo térmico é se a transferência de calor dentro do alimento ocorre por condução ou convecção. Em um alimento aquecido por condução sem agitação haverá um gradiente de temperatura a partir da superfície, que é a temperatura do processo, em direção 
ao centro, de modo que é inevitável que as camadas exteriores do produto tenham um processamento mais acentuado que o centro (Ryley \& Kajda, 1994). Já a transferência de calor por convecção é o principal tipo de transferência de calor entre a superfície de um material sólido e o líquido que o rodeia, e sua taxa depende das propriedades do fluido e das características do fluxo do fluido (Heldman \& Lund, 2007).

Em geral, a maior perda de vitaminas de um alimento ocorre geralmente durante a etapa final de preparação antes do consumo. Esta perda pode ser decorrente do cozimento caseiro ou de operações da cadeia produtiva. Assim, o teor de vitamina real de um alimento particular pronto é frequentemente o mesmo, independentemente do tipo de processamento, ou da falta de processamento, que o alimento foi submetido. Perdas significativas de vitaminas podem ocorrer em cada uma das várias fases de preparação de alimentos, incluindo (i) o corte preliminar, lavagem, imersão, corte em fatias, o ato de picar; (ii) o processo de cozimento; (iii) retenção do alimento cozido sob vapor, forno de aquecimento sob ar insuflado, ou sob lâmpada infravermelha; (iv) armazenamento do alimento em geladeira ou congelador; e ( $v$ ) reaquecimento dos alimentos armazenados. As maiores perdas durante o cozimento em casa são devido à lixiviação de vitaminas hidrossolúveis na água de cozimento (Ball, 2006).

\section{Processamento por Micro-ondas}

Há um enorme potencial de oportunidades na exploração dos benefícios de tecnologias electromagnéticas como aquecimento óhmico, infravermelho e micro-ondas no processamento de alimentos. Estas tecnologias podem ser aplicadas de diferentes maneiras, dependendo dos requisitos do processamento e da procura dos consumidores. O processamento dos alimentos é um requisito necessário para a extensão da sua vida de prateleira. No entanto, esses processamentos geralmente envolvem um tratamento térmico dos alimentos que pode reduzir sua qualidade organoléptica. Ao longo dos anos, os pesquisadores têm otimizado os perfis de tempo/temperatura para minimizar a exposição dos alimentos ao calor. Além disso, as novas tecnologias têm o potencial de reduzir ou mesmo eliminar a exposição ao calor. Alguns destes processos não são novos, mas têm ganhado recentemente avanços significativos para sua comercialização (Vikram, 2005). 
Entre estas tecnologias promissoras está o uso de micro-ondas. As micro-ondas são ondas eletromagnéticas de energia radiante, que penetram facilmente em materiais contendo moléculas dielétricas como a água. O campo electromagnético de oscilação rápida força a reorientação rápida das moléculas. Neste processo, a energia electromagnética é convertida em energia térmica. No cozimento convencional, o calor é aplicado na superfície do alimento e logo conduzido para o interior do alimento com distribuição desigual. As micro-ondas geram calor em todo o alimento, resultando em um aumento de temperatura comparativamente uniforme e rápido ao produto (Ball, 2006).

O aquecimento por micro-ondas tem o potencial de uma maior retenção de vitaminas termolábeis em comparação com outros métodos convencionais porque o tempo de aquecimento é reduzido (Ball, 2006; Lesková et al., 2006).

\section{Processamento por Radiação lonizante}

O tratamento por radiação é um processo no qual os alimentos são expostos à radiações ionizantes emitidas por radioisótopos ${ }^{60} \mathrm{Co}$, elétrons de alta energia e raios $X$ produzidos por máquinas. Dependendo da dose de radiação absorvida, vários efeitos podem ser alcançados, resultando na redução de perdas por estocagem, extensão da vida útil e/ou melhora microbiológica e segurança parasitológica dos alimentos (Farkas, 2006; Farkas et al., 2011).

Os alimentos em geral contêm alguns componentes-chaves que, embora presentes em concentrações muito baixas regulam o sabor, aspecto e valor nutritivo (WHO, 1994; Kitazuru et al., 2004; Fanaro et al., 2011). Esses componentes são muito sensíveis à irradiação e, se a dose de radiação for alta, pode causar transformações prejudiciais no sabor, odor e cor desses alimentos (Villavicencio, 2000; Delincée, 1998). O processo de irradiação causa alterações mínimas no aroma, sabor, cor e perfil nutritivo dos alimentos (Alothman et al., 2009). Pesquisas mostram que macronutrientes como proteínas e carboidratos são relativamente estáveis a doses de até 10 kGy e micronutrientes, especialmente vitaminas, podem ser sensíveis a quaisquer tratamentos de alimentos (Villavicencio et al., 2000).

Este tratamento pode ser realizado após a embalagem do produto e acarreta alterações mínimas a produtos frescos e perecíveis, que podem ser 
conservados por mais tempo sem perder sua qualidade. A irradiação de alimentos é um dos mais efetivos meios para desinfestar alimentos secos e se mostra promissora como um tratamento fitossanitário no controle de pestes, como parte de um programa de quarentena. A desinfestação previne perdas causadas por insetos em grãos estocados, farinhas, cereais, grãos de café, frutas secas e outros produtos alimentícios. A dose requerida para o controle de insetos é bem baixa, da ordem de 1,0 kGy ou inferior (Morehouse, 2002).

A legislação brasileira (RDC n²1/2001) aprovou o uso da radiação em qualquer alimento com qualquer dose, desde que sejam observadas as seguintes condições: a) a dose mínima absorvida deve ser suficiente para alcançar a finalidade pretendida; b) a dose máxima absorvida deve ser inferior àquela que comprometa as propriedades funcionais e/ou atributos sensoriais dos alimentos; c) a embalagem deve ter condições higiênicas aceitáveis para o processo de irradiação e d) o rótulo do produto deve conter os dizeres "alimento tratado por irradiação" ou o símbolo da radura (FIG. 3). Esta resolução ainda estabelece que quando um produto irradiado é usado como ingrediente em outro alimento, este fato deve ser mencionado na embalagem final indicando que o alimento foi tratado por irradiação.

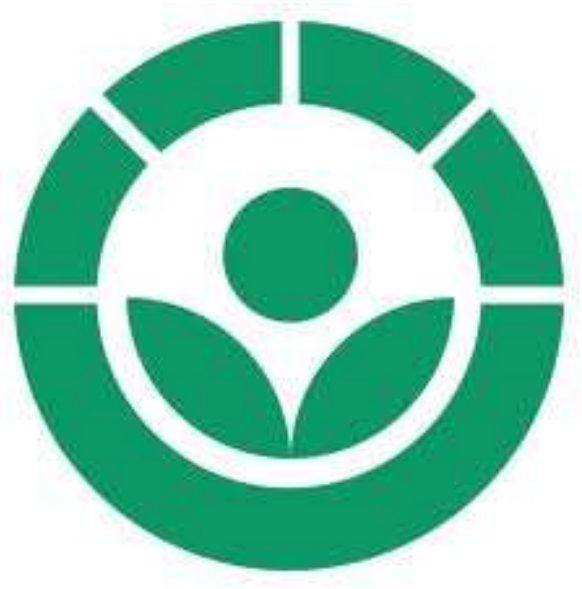

FIGURA 3. Radura: símbolo utilizado para identificar produtos irradiados. 
A radiação ionizante quando é absorvida por um material biológico, pode ter ação direta ou indireta sobre o material que recebeu este processamento. Quando a radiação ionizante é absorvida por um material biológico, existe a possibilidade de que esta irá agir diretamente em alvos críticos na célula, como a molécula de DNA. As moléculas de ácido nucléico podem ser ionizadas ou excitadas, e por meio disso, iniciar a cadeia de eventos que conduzem às mudanças biológicas e à morte celular, se a mudança é suficientemente séria. Este é o efeito direto da radiação. $O$ efeito indireto é ocasionado pela interação da radiação com a molécula de água e também outras moléculas presentes na matéria, produzindo os radicais livres. Os diversos produtos da radiólise da água, como por exemplo, radicais hidroxila $(\cdot \mathrm{OH})$, elétrons hidratados $\left(e^{-} \mathrm{H}_{2} \mathrm{O}\right)$, radicais de hidrogênio $(\cdot H)$, moléculas de hidrogênio $\left(\mathrm{H}_{2}\right)$, peróxido de hidrogênio $\left(\mathrm{H}_{2} \mathrm{O}_{2}\right)$ e prótons hidratados $\left(\mathrm{H}_{3} \mathrm{O}^{+}\right)$, podem reagir com compostos e componentes dos alimentos. O radical hidroxila é um poderoso agente oxidante, enquanto o elétron hidratado é um forte agente redutor. Desta forma, tanto reações de oxidação como reações de redução podem acontecer quando compostos e/ou alimentos contendo água são irradiados (von Soontag, 1987; WHO, 1994; Diehl, 1995; Tritsch, 2000). 


\section{CAPÍTULO 2: ESTUDO DOS EFEITOS DE DIFERENTES PROCESSAMENTOS DE ALIMENTOS NO ÁCIDO FÓLICO E ELUCIDAÇÃO DOS PRODUTOS DE DEGRADAÇÃO}

\section{MATERIAIS E MÉTODOS}

\subsection{Reagentes e Solventes}

\subsubsection{Reagentes}

O AF e os produtos de degradação 6-carboxipterina (PCA), paminobenzoil-L-ácido glutâmico (pABGA), ácido para-aminobenzóico (PABA), N(4-nitrobenzoil)-L-ácido glutâmico hemihidratado (pNBGA) e ácido pteróico (PA) foram adquiridos na Sigma-Aldrich (Steinheim, Alemanha). Xantopterina monohidratada (XA) foi adquirida na Acros Organics (Geel, Bélgica). 2-amino-6(hidroximetil)pteridina-4(1H)-one (AHMP) foi adquirido da Florida Center for Heterocyclic Compounds (Flórida, Estados Unidos). Hidróxido de sódio $(\mathrm{NaOH})$ foi adquirido da SDS (Peypin, França). Acetato de amônio foi adquirido da Merck (Darmstadt, Alemanha).

\subsubsection{Solventes}

A água foi purificada usando um sistema Synergy Milli-Q System (Millipore, Molsheim, França). Metanol (MeOH) (Carlo Erba, Val de Reuil, França) e acetonitrila (ACN) (Sigma-Aldrich, Steinheim, Alemanha) foram de grau cromatografia líquida de alta eficiência (HPLC). Todos os outros reagentes foram de grau analítico. O ácido fórmico e o ácido acético foram adquiridos da Riedelde-Haen/Fluka (Seelze, Alemanha). 


\subsubsection{Soluções estoque}

Todas as amostras padrões de AF foram preparadas sob o abrigo da luz para proteger o AF da degradação oxidativa. A fim de avaliar tanto a resposta dependente de pH como o efeito da solubilização, o AF em solução, em pó e em suspensão foram preparados sob quatro diferentes condições: (a) $100 \mathrm{mg}$ de AF foram solubilizados em um volume total de $100 \mathrm{~mL}$ de água com adição de $5,0 \mathrm{~mL}$ de $\mathrm{NaOH} 1 \mathrm{M}$. A solução foi diluída em água a uma concentração final de 0,1 $\mathrm{mg} / \mathrm{mL}$ ( $\mathrm{pH}=12,0$ ); (b) $100 \mathrm{mg}$ de AF foram solubilizados em um volume total de $100 \mathrm{~mL}$ de água com adição de $0,5 \mathrm{~mL}$ de $\mathrm{NaOH} 1 \mathrm{M}$. A solução foi diluída em água em uma concentração final de $0,1 \mathrm{mg} / \mathrm{mL}(\mathrm{pH}=8,0)$; (c) $100 \mathrm{mg}$ de $A F$ foram solubilizados em um volume total de $1000 \mathrm{~mL}$ de água com adição de $100 \mathrm{~mL}$ de acetato de amônio $0,4 \mathrm{M}$, resultando em uma concentração final de $0,1 \mathrm{mg} / \mathrm{mL}$ ( $\mathrm{pH}=6,8)$; (d) $70 \mathrm{mg}$ de $\mathrm{AF}$ foram misturados a $700 \mathrm{~mL}$ de água, resultando em uma concentração final de $0,1 \mathrm{mg} / \mathrm{mL}$ (suspensão); (e) $A F$ em pó. Antes da irradiação, um conjunto de amostras foi selado em presença de $\mathrm{O}_{2}$ e outro conjunto em presença de $\mathrm{N}_{2}$ (substituindo o espaço de ar com gás $\mathrm{N}_{2}$ puro durante $1 \mathrm{~min}$ ). As soluções, suspensões e AF em pó, foram embaladas em sachês plásticos de poliamida/polietileno (4 $\mathrm{mm}$ de espessura), seladas $\mathrm{e}$ etiquetadas com suas respectivas doses de radiação. As soluções de AF foram diretamente injetadas no sistema cromatográfico após o processamento por irradiação. $\mathrm{O} A \mathrm{~F}$ em pó e em suspensão foram primeiramente solubilizados com adição de água e $\mathrm{NaOH} 1 \mathrm{M}$, como descrito acima.

O PABA, pABGA e pNBGA foram dissolvidos e diluídos em água $\mathrm{pH}$ 7,0 enquanto o PCA, o PA, o XA e o AHMP foram dissolvidos e diluídos em água alcalina, todos a uma concentração final de $0,1 \mathrm{mg} / \mathrm{mL}$. 


\subsection{Métodos}

\subsubsection{Processamento por radiação}

As soluções e suspensões de AF e amostras de farinha de trigo fortificadas foram irradiadas com um acelerador de elétrons Van de Graaff Ebeam, $2 \mathrm{MeV}$ (Vivirad High Voltage, Handschuheim, França) com $100 \mu \mathrm{A}$ de corrente, $20 \mathrm{~cm}$ de largura de feixe e taxa de dose de aproximadamente $2 \mathrm{kGy} / \mathrm{s}$. As doses de radiação aplicadas foram de aproximadamente 0 (controle); 0,25; 0,5; 0,75; 1,0; 3,0; 5,0; 7,0 e 10,0 kGy. As doses absorvidas foram monitoradas com dosímetros radiocrômicos FWT 60.00 (Far West Technology, Goleta, CA), previamente calibrados com dosímetros de alanina (Aérial, Illkirch, França) (Kuntz et al., 1996). A uniformidade de dose foi de aproximadamente $10 \%$ dentro da amostra e esta foi alcançada pelo uso de uma lâmina de espalhamento de cobre de $100 \mu \mathrm{m}$ de espessura (Kuntz et al., 1990). Durante a irradiação, condições padrões de temperatura e pressão foram utilizadas $\left(25^{\circ} \mathrm{C}\right.$ e $\left.0,1 \mathrm{MPa}\right)$.

\subsubsection{Processamento por calor}

Amostras de AF em pó $(20 \mathrm{mg}$ ) foram depositadas no fundo de recipientes de vidro e aquecidas em estufa com temperatura constante de $200^{\circ} \mathrm{C}$. $\mathrm{O}$ aquecimento foi realizado durante 0 (controle), 10, 15, 30, 45, 60, 120 e 180 $\min$

\subsubsection{Processamento por micro-ondas}

As soluções de $\operatorname{AF}(0,1 \mathrm{mg} / \mathrm{mL}, \mathrm{pH} 12,0)$ foram processadas em um forno micro-ondas em sistema fechado (Multiwave 3000, Anton Paar, Austria). A potência aplicada foi de $1000 \mathrm{~W}$ e a pressão máxima atingida de $6,0 \mathrm{MPa}$. O tempo de aquecimento foi de 0 (controle), 5, 10, 15, 20 e 25 min. 


\subsection{Separações cromatográficas}

\subsubsection{Cromatografia Líquida de Alta Eficiência (HPLC)}

O trabalho experimental foi realizado usando dois sistemas HPLC Varian ProStar (Palo Alto, CA). O primeiro sistema era constituído de uma bomba binária ProStar 9012, injetor automático 9300 e detector por rede de diodos 330 (DAD) UV-vis. O controle do equipamento HPLC e a análise dos dados foram realizados pelo software Interactive Graphics versão 6.9.1 (Varian MS Workstation). A separação cromatográfica foi feita com uma coluna analítica Hypersil Gold aQ C18 (250 x 4,6 mm; tamanho de partícula de $5 \mu \mathrm{m}$ ) (Thermo Scientific), protegida por uma pré-coluna ODS (Uniguard, Thermo Scientific). Trata-se de uma coluna C18, a qual por apresentar end-capping hidrófobo admite o uso de fases móveis fortemente aquosas e permite a retenção de compostos mais polares do que uma coluna C18 convencional. Deste modo, proporciona uma solução aos problemas inerentes das fases contendo grupos alquilo convencionais como o arrasto de picos de compostos básicos e a retenção insuficiente de compostos hidrofílicos. A fase móvel consistiu de água/ácido fórmico $(\mathrm{pH} 3,5)$ e $\mathrm{MeOH}$, com um fluxo de $1,0 \mathrm{~mL} / \mathrm{min}$. O gradiente utilizado está resumido na TAB. 2.

TABELA 2. Gradiente de eluição em cromatografia analítica (Método 1)

\begin{tabular}{ccc}
\hline Tempo $(\mathrm{min})$ & $\% \mathrm{MeOH}$ & $\% \mathrm{H}_{2} \mathrm{O}(\mathrm{pH} 3,5)$ \\
\hline 0 & 5 & 95 \\
10 & 5 & 95 \\
30 & 50 & 50 \\
31 & 5 & 95 \\
45 & 5 & 95 \\
\hline
\end{tabular}

O segundo foi constituído de bomba binária ProStar 210, injetor automático ProStar 410 e detector por rede de diodos 335 (DAD) UV-vis]. A separação cromatográfica foi feita com uma coluna analítica Agilent-XDB Phenyl 
(250 x 4,6 mm; tamanho de partícula de $5 \mu \mathrm{m}$ ). A fase móvel consistiu de água/ácido acético $(\mathrm{pH} \mathrm{2,8)} \mathrm{e} \mathrm{MeOH}$, com um fluxo de 1,0 mL/min. O gradiente utilizado está resumido na TAB. 3.

TABELA 3. Gradiente de eluição em cromatografia analítica (Método 2)

\begin{tabular}{ccc}
\hline Tempo (min) & $\% \mathrm{MeOH}$ & $\% \mathrm{H}_{2} \mathrm{O}(\mathrm{pH} 2,8)$ \\
\hline 0 & 0 & 100 \\
10 & 0 & 100 \\
52 & 45 & 55 \\
53 & 0 & 100 \\
65 & 0 & 100 \\
\hline
\end{tabular}

Em ambos os sistemas o volume de injeção utilizado foi $20 \mu \mathrm{L}$. A detecção foi realizada a $280 \mathrm{~nm}$. A fim de controlar o sistema analítico, água (controle negativo) e solução aquosa de $\mathrm{AF} 0,1 \mathrm{mg} / \mathrm{mL} \quad(\mathrm{pH} 12,0)$ foram injetadas durante a análise das amostras a cada 10 injeções. A identificação do AF foi feita pela comparação do tempo de retenção e do espectro de absorção UV (detecção DAD).

Foi realizada a quantificação analítica do ácido fólico e dos produtos de degradação através de uma curva de calibração externa.

\subsubsection{Análise Quantitativa do AF e de seus produtos de} degradação

A quantificação do AF e de seus produtos de degradação foi realizada por padronização externa com soluções padrão dos diferentes compostos. Para este fim, uma solução padrão de cada composto $(1000 \mu \mathrm{g} / \mathrm{mL})$ foi inicialmente preparada com água $\mathrm{pH}$ 7,0 ou água alcalina (de acordo com o composto como descrito na seção 1.1.3). Desta foi feita diluição seriada para o preparo da curva de calibração com sete pontos diferentes, na faixa de 1,56 a $100 \mu \mathrm{g} / \mathrm{mL}$. Todas as soluções de calibração padrão foram preparadas sob o abrigo da luz e armazenadas em frascos âmbar. 
O limite de detecção (LDD) foi definido como a menor concentração do analito que apresentasse uma razão sinal/ruído $(\mathrm{S} / \mathrm{N})$ de 3 . O limite de quantificação (LDQ) foi definido como a menor concentração do analito que apresentasse uma razão sinal/ruído (S/N) de 10.

As amostras foram analisadas em triplicata. As concentrações do AF e dos produtos de degradação foram expresss em $\mu \mathrm{g} / \mathrm{mL}$. Para a comparação das médias aritméticas, empregou-se o teste ANOVA e o teste de Tukey usando o software Statgraphics Plus para Windows. Adotou-se o nível de significância de $5 \%$ de probabilidade $(p<0,05)$.

\subsubsection{Cromatografia Líquida de Alta Eficiência para Coleção de}

\section{Frações}

A purificação foi realizada usando um sistema cromatográfico semipreparativo para coleção de frações Gilson PLC 2020 (Villiers-le-Bel, França). Foi utilizada coluna Agilent-XDB Phenyl (250 x 4,6 mm; tamanho de partícula de $5 \mu \mathrm{m})$. As soluções injetadas foram de 0,1 ou $1 \mathrm{mg} / \mathrm{mL}$. O fluxo foi de $1 \mathrm{~mL} / \mathrm{min}$ e um volume máximo de injeção de $150 \mu \mathrm{L}$. O gradiente utilizado está resumido na TAB. 4. As frações coletadas foram concentradas com a ajuda de um concentrador de amostras Savant SPD 121P (Thermoscientific, EUA) sob vácuo usando bomba/trap RVT4101 (Thermoscientific, EUA) com temperatura entre -95 e $-100^{\circ} \mathrm{C}$. A duração de evaporação foi variável em função do volume inicial coletado. A temperatura foi fixada em $40^{\circ} \mathrm{C}$ para inibir qualquer possível degradação. 
TABELA 4. Gradiente de eluição em cromatografia analítica (Método 3)

\begin{tabular}{ccc}
\hline Tempo $(\min )$ & $\% \mathrm{MeOH}$ & $\% \mathrm{H}_{2} \mathrm{O}(\mathrm{pH} \mathrm{2,8})$ \\
\hline 0 & 0 & 100 \\
10 & 0 & 100 \\
66 & 60 & 40 \\
70 & 60 & 40 \\
71 & 0 & 100 \\
80 & 0 & 100 \\
\hline
\end{tabular}

\subsubsection{Espectrometria de Massas}

As análises de massa foram efetuadas usando um sistema cromatográfico Varian ProStar HPLC (Palo Alto, CA) constituído de uma bomba binária ProStar 210, amostrador automático 410 e espectrômetro de massas (MS) triplo quadrupolo Varian 1200L equipado de uma fonte de ionização por eletrospray (ESI) (Varian, Les Ulis, França). O controle do equipamento LC-MS e a análise dos dados foram realizados pelos softwares Interactive Graphics e MS Data Review versão 6.9.1 (Varian MS Workstation). A separação cromatográfica foi realizada na mesma coluna analítica Agilent-XDB Phenyl (250 x 4,6 mm; tamanho de partícula de $5 \mu \mathrm{m}$ ) anteriormente descrita (seção 1.3.1). O volume de injeção foi de $20 \mu \mathrm{L}$ e o fluxo de $1 \mathrm{~mL} / \mathrm{min}$. As condições cromatográficas foram as descritas no método 2 (seção 1.3.1), sendo que na saída da coluna $80 \%$ do fluxo foi dirigido em direção ao detector de rede de diodos e $20 \%$ em direção ao espectrômetro de massas. Tratava-se de um triplo quadrupolo equipado de uma câmara de ionização por eletrospray. O detector foi operado em modo EDR (Extended Dynamic Range), em modo positivo e negativo, com aquisição de dados na gama m/z entre 70 e 500. A tensão do capilar de nebulização foi de $5000 \mathrm{~V}$, a tensão do capilar de transferência de íons de $71 \mathrm{~V}$ e a tensão do cone de 600 V. Nitrogênio de alta pureza fornecido por um gerador (Domnik Hunter, Villefranche sur Saône, França) foi usado como gás de nebulização com pressão de 46 psi (3,2 MPa) e como gás de secagem $\left(200^{\circ} \mathrm{C}\right)$. A acoplagem do HPLC ao MS permitiu a determinação do peso molecular do produto puro e aquisição de informações estruturais a partir da natureza dos fragmentos obtidos. Observa-se 
geralmente o íon correspondente ao peso molecular mais ou menos um próton $[\mathrm{M}+\mathrm{H}]^{+}$ou $[\mathrm{M}-\mathrm{H}]^{+}$. Estas informações permitem de deduzir o peso molecular do composto em estudo. Também foi utilizada a espectrometria de massa em sequência que serve no estudo de misturas de compostos conhecidos e desconhecidos. Um íon «pai » advindo da fragmentação inicial é selecionado e novamente submetido à fragmentação, originando íons «filhos ". Em misturas complexas, estes íons filhos provam de maneira inequívoca a presença dos compostos conhecidos. Para os compostos desconhecidos, estes íons provem informações estruturais potenciais.

\subsubsection{Espectrometria de Massas de Alta Resolução}

Análises de confirmação foram realizadas com um espectrômetro de massas de alta resolução (HRMS) (Agilent Technologies, Massy, França) [bomba binária G1312B, amostrador automático G1367C munido de termostato G1316B, detector por rede de diodos DAD SL G1315C e de um espectrômetro de massas Accurate Mass Q-TOF G6520 A]. O controle do equipamento LC-HRMS e a análise dos dados foi realizada pelos softwares ChemStation e MassHunter (Agilent). Este último permite a geração das fórmulas brutas dos produtos desconhecidos. A separação cromatográfica foi feita com uma coluna analítica Thermo Hypersil Gold C8 (100 x 1,0 mm; tamanho de partícula de 1,9 $\mu \mathrm{m})$. A fase móvel consistiu de água/ácido fórmico (0,05\%) e ACN, com um fluxo de 0,1 $\mathrm{mL} / \mathrm{min}$. Um volume de injeção de $0,4 \mu \mathrm{L}$ foi utilizado. $O$ gradiente utilizado está resumido na TAB. 5.

TABELA 5. Gradiente de eluição em cromatografia analítica (Método 4)

\begin{tabular}{ccc}
\hline Tempo $(\mathrm{min})$ & $\% \mathrm{ACN}$ & $\% \mathrm{H}_{2} \mathrm{O}(0,05 \%)$ \\
\hline 0 & 0 & 100 \\
2 & 0 & 100 \\
8 & 95 & 5 \\
14,5 & 95 & 5 \\
15 & 0 & 100 \\
\hline
\end{tabular}


O gradiente de eluição começou com $100 \%$ de água/ácido fórmico entre 0 e 2 min, seguido de uma aumento da concentração de $A C N$ até $95 \%$ em 6 min. A concentração de $A C N$ foi mantida em $95 \%$ entre 8 e 14,5 min. Subsequentemente, a concentração de ACN diminui a $0 \%$ em 0,5 min. 


\section{RESULTADOS E DISCUSSÃO}

\subsection{Efeitos dos diferentes processamentos na degradação do AF}

\subsubsection{Efeito do processamento por radiação ionizante}

\section{Soluções Aquosas de AF}

Neste estudo foi avaliado o efeito da irradiação com feixe de elétrons sobre soluções aquosas de AF $(0,1 \mathrm{mg} / \mathrm{mL})$ em diferentes valores de $\mathrm{pH}$, uma vez que este parâmetro é de extrema importância na estabilidade da molécula de AF. Igualmente, também foram analisadas duas diferentes condições de atmosfera, com oxigênio e com o gás inerte $\mathrm{N}_{2}$, já que o oxigênio também tem papel importante durante o processamento por radiação.

\section{- Efeito da irradiação em função da dose}

As soluções aquosas de AF irradiadas mostraram uma relação decrescente entre sua concentração e as doses de radiação absorvidas (FIG. 4). Soluções aquosas de AF mostraram uma degradação pronunciada até mesmo com doses inferiores a 1 kGy (FIG. 4). Houve uma redução de $60 \%$ a $80 \%$ no conteúdo de AF. Doses superiores a 1 kGy promoveram uma forte degradação do AF e notavelmente a partir de 3 kGy foi encontrado apenas $10 \%$ do conteúdo inicial de $A F$ (FIG. 4). Doses de radiação superiores a 5 kGy promoveram uma completa degradação do AF, para todas as soluções testadas, independente do $\mathrm{pH}$ ou atmosfera utilizada $(\mathrm{p} \geq 0,05)$. 

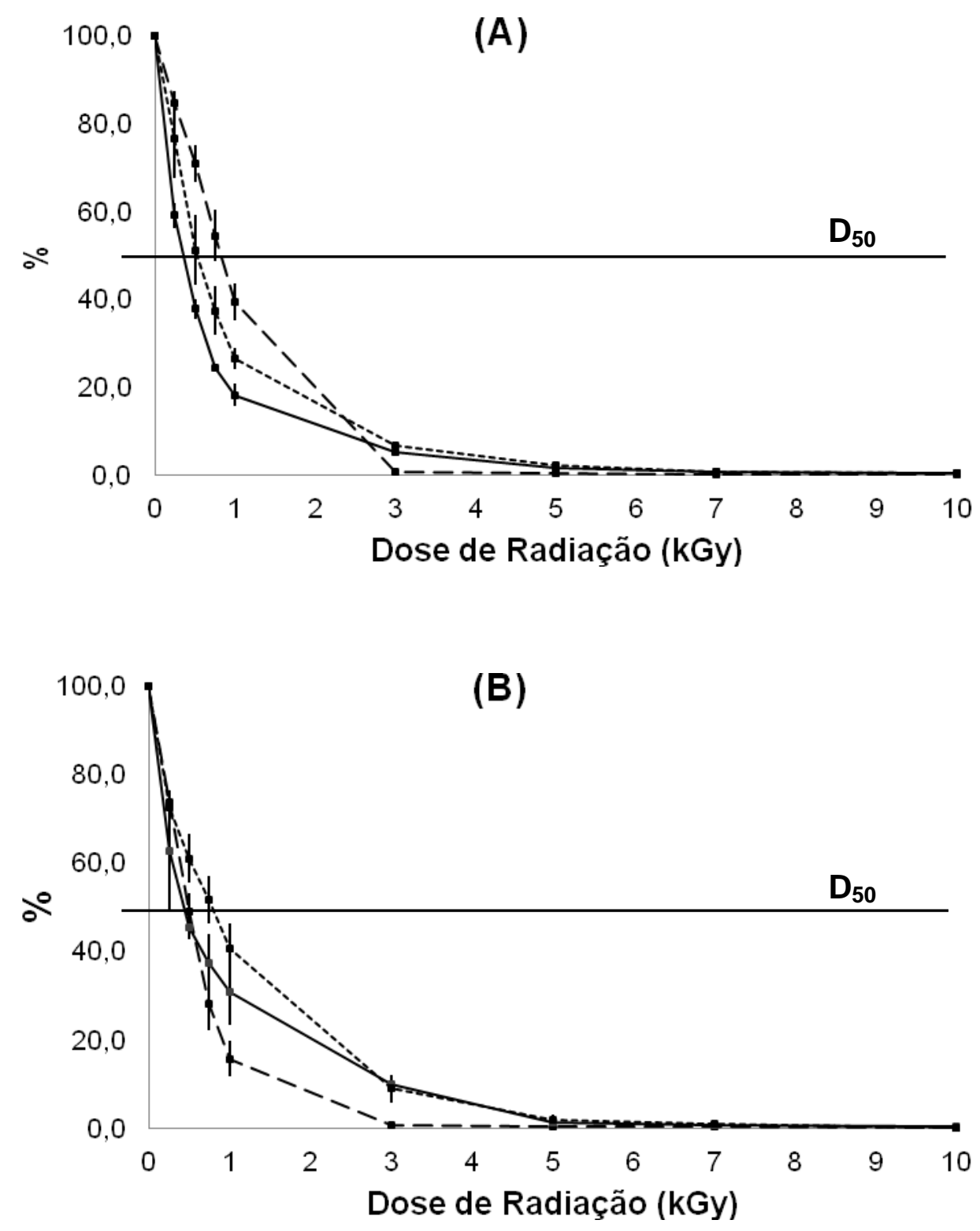

FIGURA 4. Porcentagem remanescente de AF em solução aquosa sob diferentes valores de $\mathrm{pH}$ com (A) $\mathrm{O}_{2}$ e (B) $\mathrm{N}_{2}(-, \mathrm{pH} 12,0 ; \cdots, \mathrm{pH} 8,0 ;-\cdots, \mathrm{pH} 6,8)$.

\section{- Efeito da irradiação em função do pH da solução}

Para avaliar o efeito da irradiação nas soluções de AF com diferentes pHs e atmosferas, de maneira similar aos estudos toxicológicos e radiológicos, foi calculado a $D_{50}$ (dose efetiva) para cada condição testada. Esta grandeza tenta representar a dose de radiação necessária para degradar o AF em 50\%. 
As soluções aquosas de $\mathrm{AF}$ com pH 12,0, apresentaram valores de $D_{50}$ de 0,37 e 0,5 kGy em presença de $\mathrm{O}_{2}$ e em presença de $\mathrm{N}_{2}$, respectivamente (TAB. 6). Para todas as doses de radiação aplicadas (0,25 a 10 kGy), não houve uma diferença significativa entre as soluções aquosas de $A F \operatorname{com~} \mathrm{O}_{2}$ e $\mathrm{N}_{2}$ (p $\geq 0,05)$ (FIG. 4).

As soluções aquosas de AF com pH 8,0, apresentaram valores de $D_{50}$ de 0,53 e 0,75 kGy, respectivamente na presença de $\mathrm{O}_{2}$ e na presença de $\mathrm{N}_{2}$ (TAB. 6). Para todas as doses de radiação aplicadas (0,25 a 10 kGy), não houve uma diferença significativa entre as soluções aquosas de $A F \operatorname{com~} \mathrm{O}_{2}$ e $\mathrm{N}_{2}$ ( $p \geq 0,05)$ (FIG. 4).

Por outro lado para soluções aquosas de AF com pH 6,8, os valores de $\mathrm{D}_{50}$ foram 0,8 e 0,42 kGy com $\mathrm{O}_{2}$ e $\mathrm{N}_{2}$, respectivamente (TAB. 6). Para estas amostras, a condição de atmosfera estudada $\left(\mathrm{O}_{2}\right.$ e $\left.\mathrm{N}_{2}\right)$ mostrou uma diferença significativa para as amostras irradiadas com 0,5; 0,75 e 1 kGy $(p<0,05)$, mostrando-se mais estável na presença de $\mathrm{O}_{2}$.

TABELA 6. Valores de $D_{50}$ (kGy) de soluções aquosas de AF a pH 6,8; 8,0 e 12,0 com $\mathrm{O}_{2}$ e $\mathrm{N}_{2}$.

\begin{tabular}{cccc}
\hline \hline & & $\mathrm{pH}$ & \\
& 6,8 & 8,0 & 12,0 \\
\cline { 2 - 4 } $\mathrm{O}_{2}$ & 0,80 & 0,53 & 0,37 \\
$\mathrm{~N}_{2}$ & 0,42 & 0,75 & 0,50 \\
\hline
\end{tabular}

A ausência de diferença significativa para a condição de atmosfera entre as soluções aquosas de AF com pH 12,0 e 8,0, pode ser explicada devido ao fato de que a água, em equilíbrio com o ar, contem pequenas quantidades de oxigênio dissolvido, que podem ser reduzidos por átomos de hidrogênio a radicais hidroperoxila $\left(\cdot \mathrm{HO}_{2}\right)$, uma agente oxidante suave. O radical hidroperóxi está em equilíbrio com o radical superóxido $\left(\cdot \mathrm{O}_{2}{ }^{-}\right)$e ambos podem produzir peróxido de hidrogênio em uma reação que consome o oxigênio; assim, uma matriz anaeróbica pode ser gerada pela radiação com elétrons em altas taxas de dose, 
como nas encontradas durante o processamento por feixe de elétrons (WHO, 1994).

Diferentemente dos resultados encontrados com soluções aquosas de AF com um pH 6,8 (ligeiramente ácidas), Thomas et al. (2000), mostraram que o AF em soluções aquosas ácidas é foto-estável em ausência de oxigênio quando comparado com as mesmas amostras em presença de oxigênio.

Estudos anteriores que avaliaram o efeito da irradiação na estabilidade do AF não realizaram ensaios sob diferentes condições de $\mathrm{pH}$ e atmosfera. Por outro lado, diversos autores estudaram os efeitos da fotólise do AF sob diferentes condições de $\mathrm{pH}$ e atmosfera. Akhtar et al. (1999) propuseram que a taxa de fotólise do AF decresce gradualmente partindo de valores de $\mathrm{pH}$ ácido a alcalinos. Entretanto, as amostras solubilizadas com 0 acetato de amônio $(\mathrm{pH}$ 6,8) pareceram tão suscetíveis ao processamento por radiação como as amostras solubilizadas com $\mathrm{NaOH}$ (pH 8,0 e 12,0) (FIG. 4). De maneira surpreendente, as amostras solubilizadas com acetato de amônio apresentaram uma sensibilidade à radiação aumentada em ausência de oxigênio quando comparada as mesmas amostras em presença de oxigênio $(p<0,05)$. 


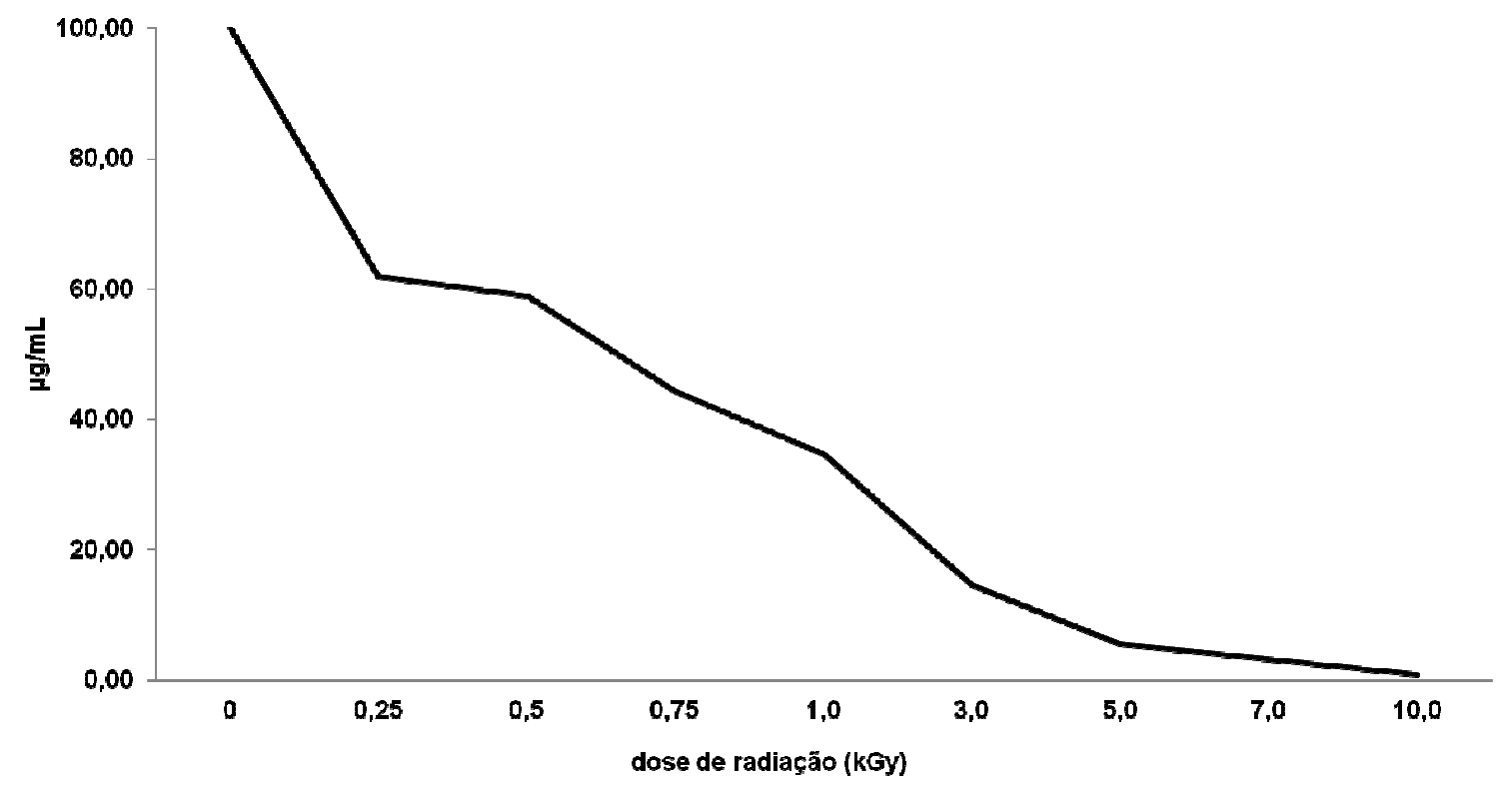

FIGURA 5. Efeito do processamento por radiação ionizante na degradação de solução de $\mathrm{AF}(\mathrm{pH} 8,0)$.

Resumidamente, independentemente da condição de atmosfera ou pH testada, houve um importante efeito da irradiação na degradação do AF para toda a faixa de doses de radiação estudadas $(0,25$ a $10 \mathrm{kGy})$, com uma redução importante da concentração do $A F$ até mesmo com uma dose de radiação de 1 kGy. (FIG. 5).

\section{Suspensões de AF}

A solubilidade do AF é crucial para a liberação de fármacos, absorção e transferência no organismo humano bem como na cristalização durante seu processo de produção. É sabido que o AF obtido de preparações farmacêuticas é mais biodisponível que os folatos adquiridos através da dieta, já que até metade é perdido durante o cozimento e requer uma etapa de hidrólise para sua absorção (Suitor \& Bailey, 2000; McNulty \& Pentieva, 2004). Sabendo que a irradiação é uma tecnologia também extensamente aplicada à fármacos e medicamentos, foi estudado o efeito do processamento por feixe de elétrons em suspensões de AF em água $(0,1 \mathrm{mg} / \mathrm{mL})$. 
Como descrito na revisão de literatura, o AF só é solúvel e estável em soluções diluídas alcalinas e igualmente se dissolve em meio ácido, porém nesta condição é instável (Ball, 2006; Guilland, 2009). O AF mostra uma baixa solubilidade água em $\mathrm{pH}$ neutro, sendo praticamente insolúvel $(0,01 \mathrm{mg} / \mathrm{mL})$.

Foi encontrada uma alta estabilidade do AF em suspensão ao processamento por radiação com feixe de elétrons. Não houve diferença significativa entre as suspensões controle não-irradiadas e as amostras irradiadas, assim a concentração de $\mathrm{AF}$ se manteve constante com todas as doses de radiação aplicadas (até 5 kGy). Pode-se perceber que neste modelo, nem o efeito direto na radiação nem o efeito indireto decorrente da radiólise da água e consequente formação de radicais livres não promoveu a degradação do AF em suspensões de AF irradiadas, ainda com doses de radiação elevadas (5 kGy).

\subsubsection{Efeito do processamento por aquecimento em estufa}

O AF tem uma importância mundial do AF na fortificação de alimentos, em especial em farinhas de trigo e milho. Sabendo que o AF em pó é comumente misturado às farinhas de trigo e milho com a finalidade de fortificação, foi realizada uma abordagem sobre a estabilidade do AF em pó ao aquecimento em estufa com temperatura constante de $200^{\circ} \mathrm{C}$. Isto se deve ao fato destes ingredientes serem consumidos logo de um processamento térmico, como por exemplo, o cozimento em forno a uma temperatura média de $200^{\circ} \mathrm{C}$.

Neste estudo, percebeu-se que o processamento do AF em pó em estufa a $200^{\circ} \mathrm{C}$ acarretou em uma degradação acentuada proporcional ao tempo de aquecimento (FIG. 6). O tratamento térmico por 15 minutos provocou uma redução de $20 \%$ da quantidade inicial do conteúdo de AF (FIG. 6). Um período de aquecimento superior a 30 minutos acarretou em uma perda de $50 \%$ do conteúdo inicial. Uma redução ainda mais pronunciada se deu passados $60 \mathrm{~min}$ de aquecimento, neste caso apenas $5 \%$ do conteúdo de AF $(5,80 \mu \mathrm{g} / \mathrm{mL})$ da quantidade inicial foi encontrada. 


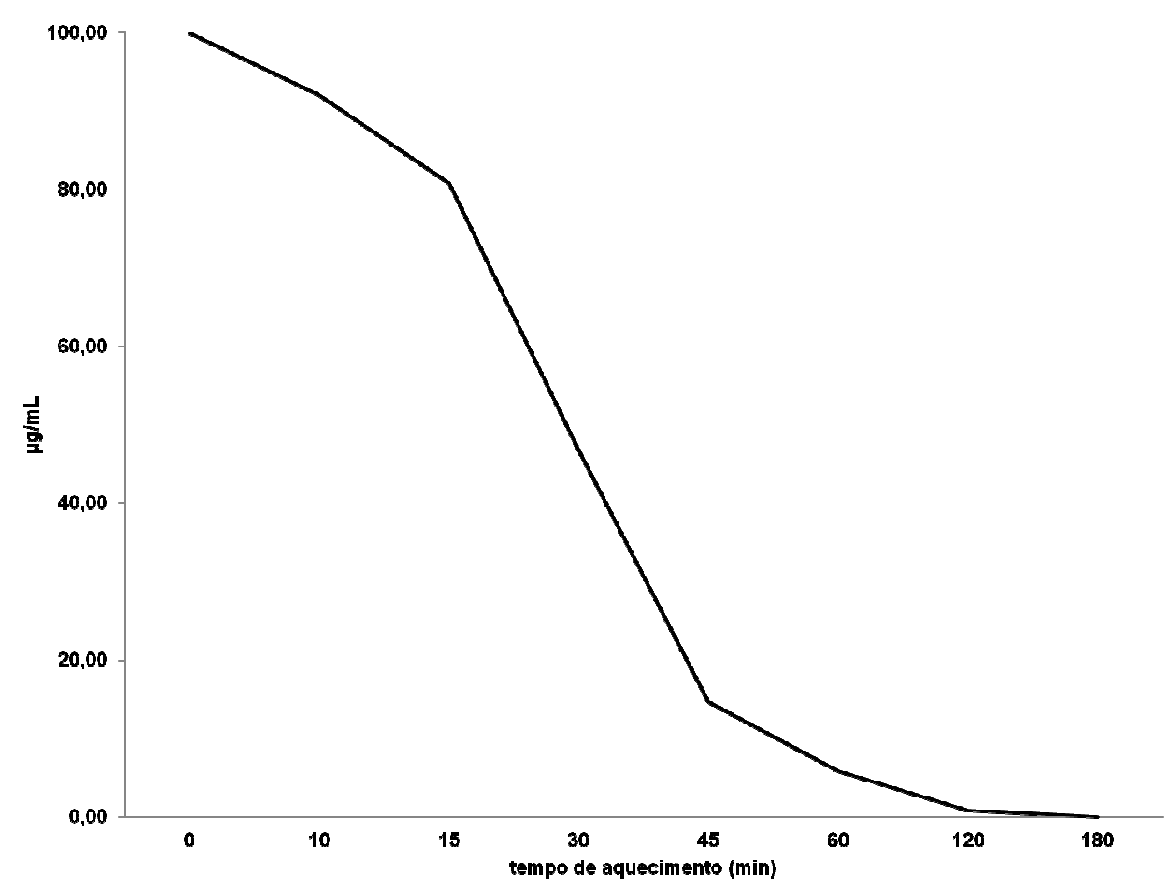

FIGURA 6. Degradação do AF decorrente do aquecimento em estufa (200ํㄷ).

Não foi realizado o aquecimento de uma solução de AF devido ao fato de ocorrer uma perda importante de volume durante este processamento. Uma abordagem tentativa sobre o efeito do calor em um solução de AF foi realizado autoclavando $\left(120^{\circ} \mathrm{C}\right)$ uma solução de $A F(0,1 \mathrm{mg} / \mathrm{mL})$ por um período de tempo de 15 e 30 min. Entretanto não houve alteração no perfil cromatográfico do AF (dados não mostrados).

\subsubsection{Efeito do processamento por micro-ondas}

A fim de avaliar o efeito do processamento por micro-ondas na estabilidade da molécula de $A F$, soluções de $A F(0,1 \mathrm{mg} / \mathrm{mL}$ a $\mathrm{pH} 12,0)$ foram aquecidas em forno micro-ondas especial em sistema fechado. Este tipo de equipamento permitiu o tratamento das soluções de AF em recipiente fechado, impedindo desta forma a perda de solvente durante o processo. A escolha deste tipo de equipamento micro-ondas se deve ao fato de que um aparelho microondas convencional, de uso doméstico, não permite o uso de recipientes 
fechados. Assim, o aquecimento de uma solução em um recipiente aberto levaria à evaporação do solvente da solução parcial e/ou totalmente, dependendo do tempo de aquecimento, dificultando as análises quantitativas do AF e eventuais produtos de degradação formados.

$\mathrm{O}$ aquecimento de uma solução de $\mathrm{AF}$ em forno micro-ondas mostrou uma degradação inexpressiva ( $2 \%$ de perda) do $\mathrm{AF}$ ao longo de $5 \mathrm{~min}$ de tratamento. Entretanto, após 10 minutos de aquecimento, a degradação do AF foi importante, acarretando uma perda de aproximadamente $98 \%$ da quantidade inicial (FIG. 7).

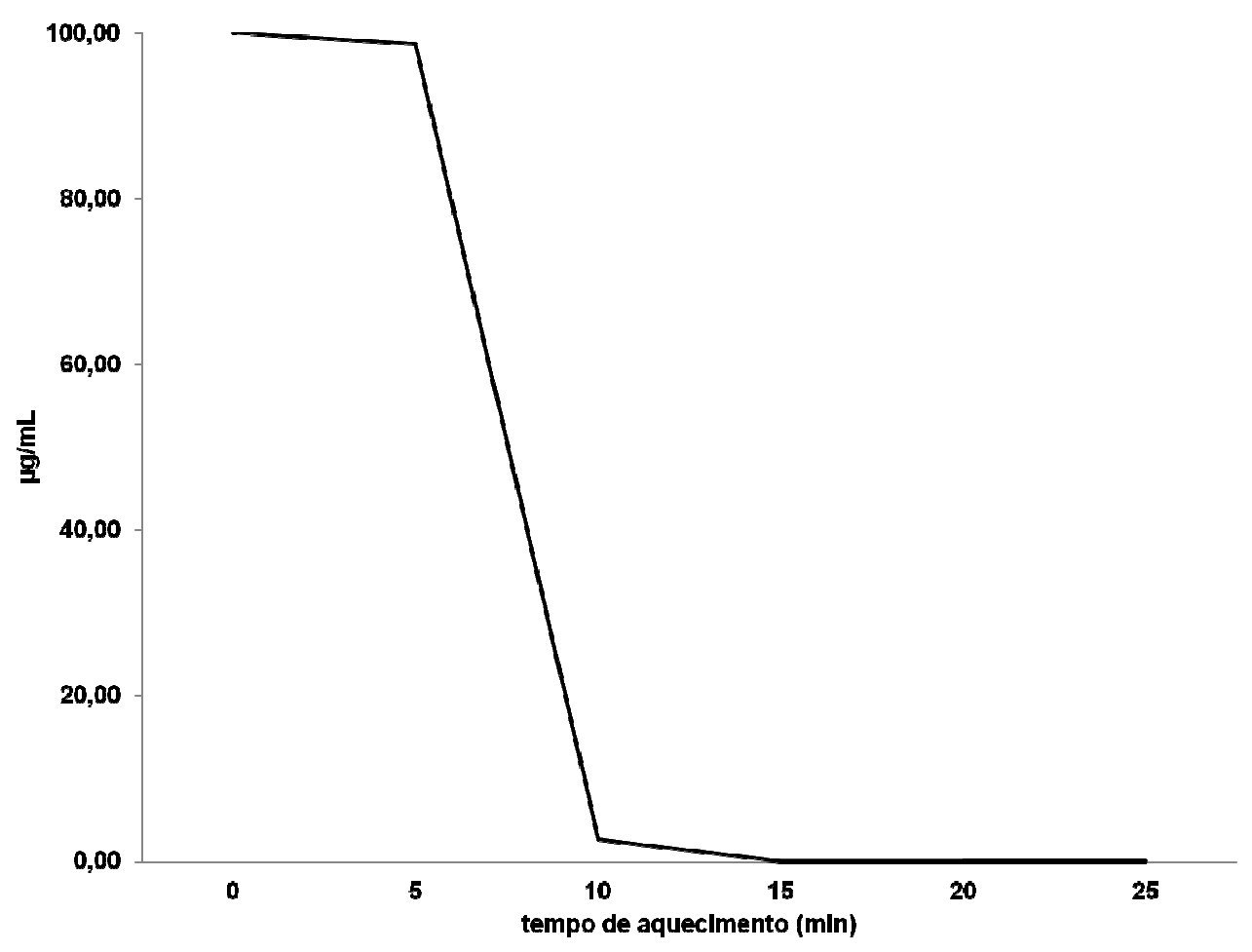

FIGURA 7. Degradação do AF decorrente do aquecimento em forno micro-ondas

Indrawati et al. (2004) realizaram um estudo comparativo sobre a estabilidade à pressão e à temperatura do 5 -metil-tetrahidrofolato $\left(5-\mathrm{CH}_{3}-\mathrm{H}_{4}\right.$ folato) em um modelo experimental e em alimentos líquidos/pastosos. Ainda que a faixa de pressão (100-700MPa) aplicada foi muito superior a realizada neste estudo, estes autores também encontraram uma aumento na degradação do 
5- $\mathrm{CH}_{3}-\mathrm{H}_{4}$ folato sob o efeito da pressão à temperaturas elevadas $\left(\geq 40^{\circ} \mathrm{C}\right)$. Por outro lado, eles preconizam uma relativa baro-estabilidade do $5-\mathrm{CH}_{3}-\mathrm{H}_{4}$ folato à temperaturas inferiores a $40^{\circ} \mathrm{C}$.

Neste estudo observou-se um efeito combinado de temperatura e pressão elevadas que promoveu uma degradação importante do AF a partir de 5 min de tratamento. No tempo $10 \mathrm{~min}$, a pressão do sistema já alcançou valores de pressão (5,32 $\mathrm{MPa})$ próximos das que o equipamento suporta e uma temperatura (194으) próxima da temperatura no final dos tratamentos (TAB. 7).

Vale ressaltar que os tratamentos foram aplicados nos tempos descritos anteriormente $(5,10,15,20$ e $25 \mathrm{~min})$ em diferentes células contendo as soluções de AF dentro do forno micro-ondas. Entretanto, antes da retirada das células do sistema foi necessário um resfriamento prévio à sua manipulação. Este tempo de espera adicional poderia explicar este efeito importante na degradação do AF durante o processo.

TABELA 7. Valores de temperatura e pressão máximos do processamento por micro-ondas.

\begin{tabular}{ccc}
\hline Tempo (min) & Temperatura máxima ( $\left.{ }^{\circ} \mathbf{C}\right)$ & Pressão máxima (MPa) \\
\hline 0 & 25 & 0,101325 \\
5 & 117 & 1,74 \\
10 & 194 & 5,32 \\
15 & 222 & 5,9 \\
20 & 231 & 6,0 \\
25 & 230 & 6,0 \\
\hline
\end{tabular}




\subsection{Identificação dos produtos de degradação do AF decorrente dos diferentes processamentos}

Dados da literatura preconizam que a estabilidade dos folatos durante o processamento de alimentos é influenciada pela temperatura, duração do aquecimento, $\mathrm{pH}$, dose de radiação, presença de oxigênio, luz, íons metálicos e antioxidantes, entre outros. Assim, foram utilizados dados prévios sobre produtos de degradação conhecidos para a análise inicial dos produtos encontrados após os tratamentos aplicados ao AF.

Notavelmente, com relação à sensibilidade dos folatos e em especial o $A F$, diversos estudos foram realizados sobre o efeito da fotólise no AF. É sabido que este processamento leva a ruptura da molécula de AF com a formação de cinco principais produtos de degradação, a saber: 6-carboxipterina (PCA), $p$ aminobenzoil-L-ácido glutâmico (pABGA), ácido pteroico (PA), ácido p-aminobenzóico (PABA) e ácido glutâmico.

Soluções padrão destes compostos de degradação conhecidos foram utilizadas para sua identificação nas amostras submetidas aos processamentos de radiação, aquecimento e micro-ondas aplicados neste estudo. Ferramentas cromatográficas e espectrométricas foram usadas para a identificação e caracterização dos produtos de degradação decorrentes destes processamentos.

Com o intuito de obter informações sobre a identificação de produtos de degradação ainda não conhecidos, foram utilizados diferentes métodos cromatográficos de análise e purificação. Foram analisadas as informações dos espectros UV destes compostos, espectros de massas (MS) e os espectros de massas em sequência $\left(\mathrm{MS}^{2}\right)$ obtidos por LC/MS e LC/MS/MS, respectivamente. Resultados confirmatórios sobre a identidade dos diversos produtos de degradação foram obtidos por espectrometria de alta resolução HRMS. Também foi utilizado um sistema cromatográfico semi-preparativo para coleção de frações dos produtos de degradação desconhecidos. 


\subsubsection{Processamento por radiação ionizante}

O tratamento por radiação acarretou uma intensa degradação do AF. Diferentes perfis foram obtidos nas análises cromatográficas das soluções aquosas de AF não-irradiada e irradiadas com doses de radiação de 1 kGy, 5 kGy, 7 kGy e 10 kGy (FIG. 8). Ainda que as soluções de AF foram irradiadas com uma ampla faixa de doses de radiação, os perfis cromatográficos para as doses de radiação de 0,25 kGy, 0,5 kGy e 0,75 kGy apresentaram perfil similar à solução aquosa irradiada com $1 \mathrm{kGy}$ (FIG. 8B). Igualmente o tratamento por radiação com doses superiores a $1 \mathrm{kGy}$ apresentou um perfil cromatográfico similar, assim foram escolhidas as doses de radiação de 5 kGy e 10 kGy para ilustrar esta faixa de doses (FIG. 8C e 8D). O AF apresentou tempo de retenção (tr) de 42,4 min. Doses de radiação crescentes vieram acompanhadas de uma importante degradação do AF e o aparecimento de diversos produtos de degradação.

O processamento por radiação com doses de até 1 kGy ocasionou o aparecimento principalmente de produtos de degradação de natureza química similar ao AF, apresentando tempos de retenção próximos ao mesmo (FIG. 8B).

Por outro lado, doses de radiação superiores a 5 kGy promoveram uma intensa quebra da molécula do $\mathrm{AF}$, originando outros produtos de degradação de natureza mais polar que o AF (FIG. 8C e 8D). 


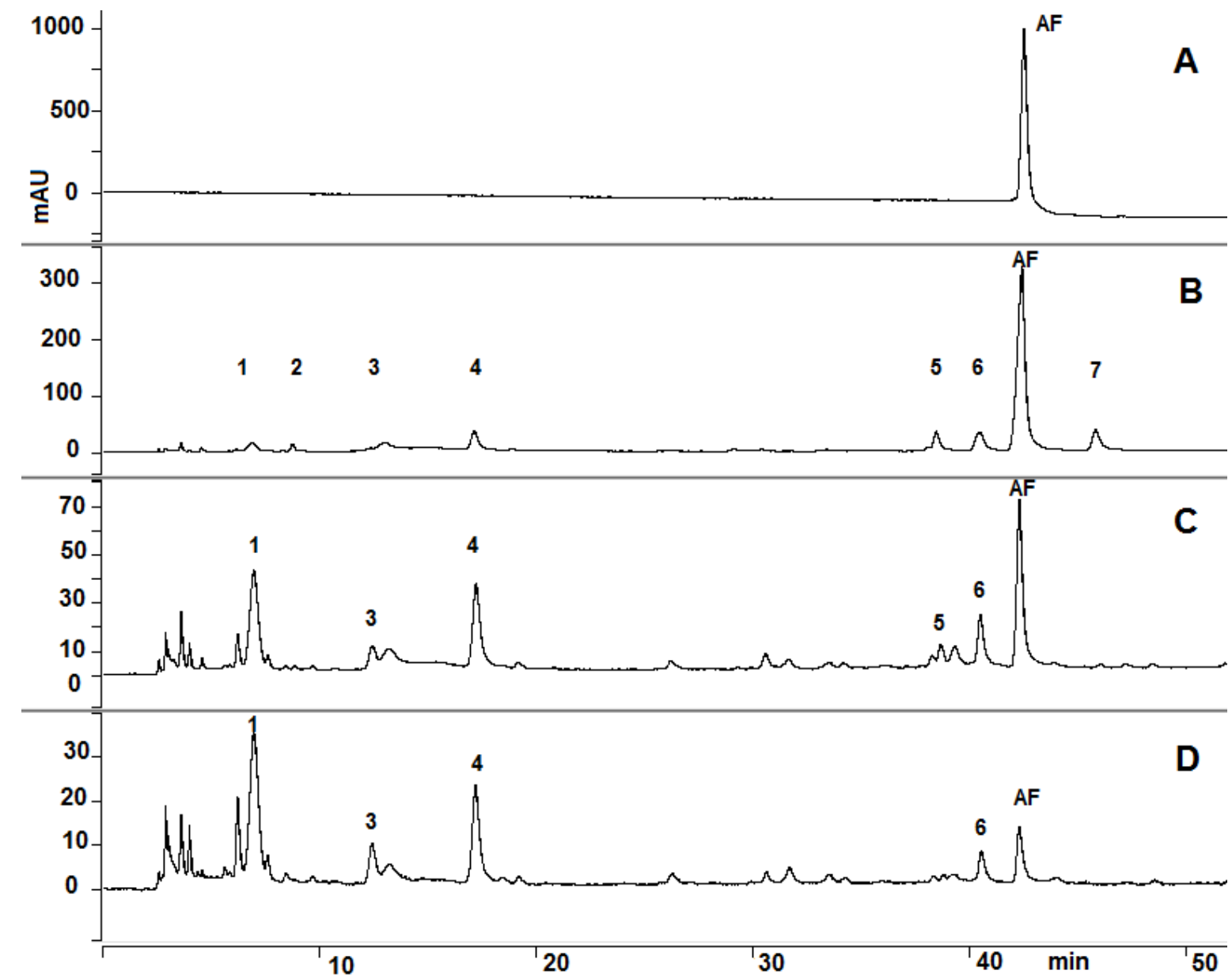

FIGURA 8. Sobreposição de perfis cromatográficos de soluções de $\operatorname{AF}(0,1$ $\mathrm{mg} / \mathrm{mL}$ ) não-irradiada (A) e irradiadas com 1 kGy (B), 5 kGy (C) e 10 kGy (D).

No perfil cromatográfico de uma solução aquosa de AF irradiada com uma dose de radiação de 1 kGy (FIG. 8B), foi notada a presença de quatro produtos de degradação majoritários com tempos de retenção (tr) 17,2; 38,5; 40,5 e 45,8 min, respectivamente os picos cromatográficos 4, 5, 6 e 7. Os perfis cromatográficos de soluções aquosas de AF irradiadas com doses de radiação de 5 kGy (FIG. 8C) e 10 kGy (FIG. 8D) evidenciaram a formação de outros produtos de degradação, representados pelos tr 6,9 e 13,2 min, respectivamente os picos cromatográficos 1 e 3.

Além dos produtos de degradação enumerados acima, outros produtos de natureza extremamente polar foram encontrados com tempo de retenção compreendido entre 2,2 e 5,0 min. Entretanto, a separação cromatográfica destes 
produtos apresentou uma resolução insatisfatória, prejudicando as análises cromatográficas e espectrométricas. Assim, faz-se necessário uma investigação futura com auxílio de outros parâmetros e/ou coluna cromatográfica para identificação destes produtos de degradação.

\section{Pico cromatográfico 3}

A comparação das informações de tr e espectro UV dos produtos de degradação já conhecidos da fotólise, levaram a indicação de que o pico cromatográfico caracterizado pelo $\mathrm{tr}=13,2 \mathrm{~min}$ (FIG.8B, pico 3) poderia tratar-se de um fotoproduto do AF. A injeção de um padrão do composto 6-carboxipterina (PCA) com o método 2 resultou na eluição deste composto no mesmo tr deste produto de degradação do AF. Na avaliação dos espectros UV do padrão de PCA e do produto de degradação eluído a 13,2 min, foram obtidos espectros UV que se sobrepuseram (FIG. 9). Estas duas informações coincidentes, de tr e espectro UV, levaram a crer que se tratasse do mesmo composto.

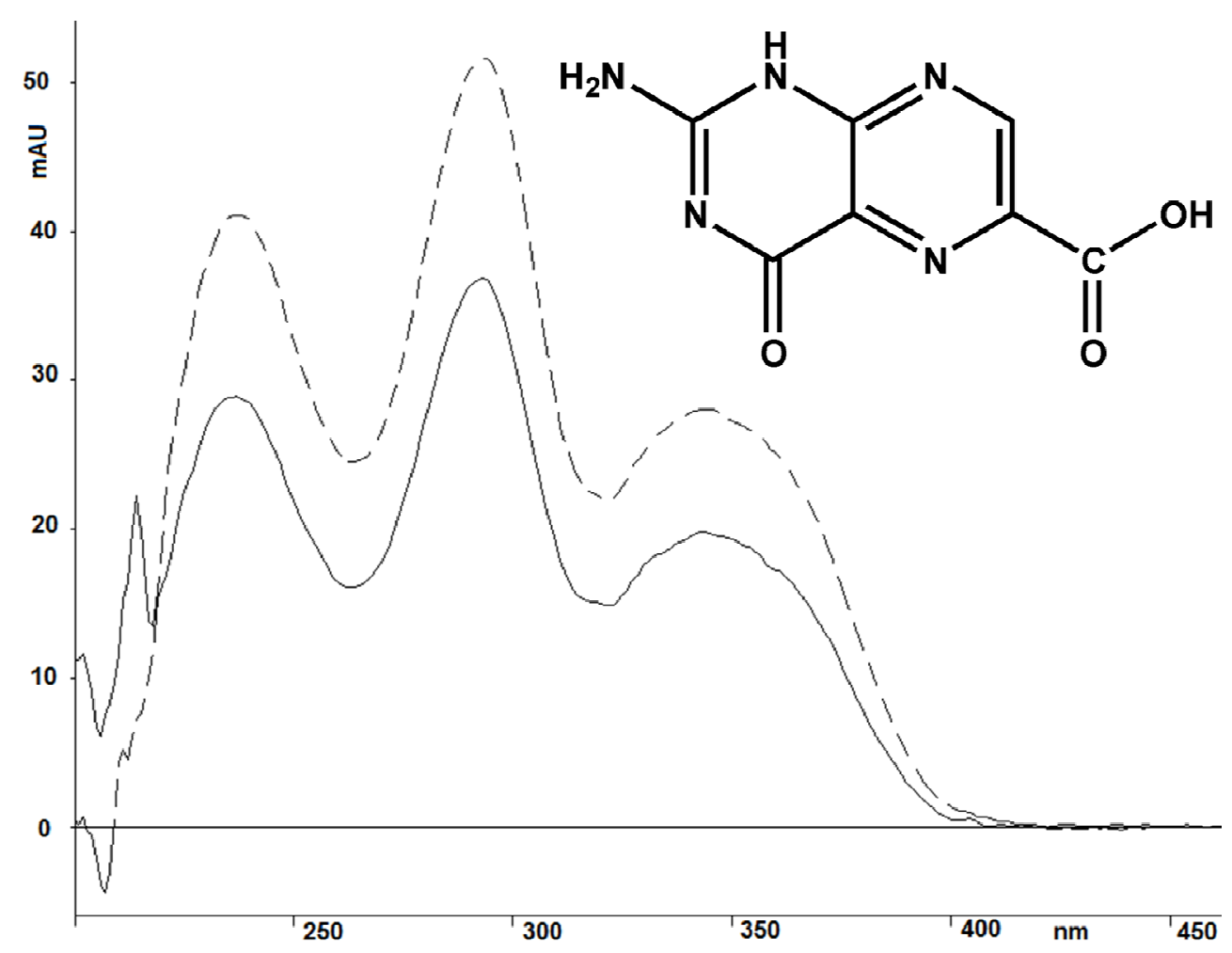

FIGURA 9. Estrutura química e espectro UV do PCA (linha pontilhada) sobreposto ao produto de degradação eluído com $\operatorname{tr}=13,2$ min (linha contínua). 
A análise deste pico cromatográfico por espectrometria de massas com eletronebulização em modo positivo (ESI+) gerou o íon $[\mathrm{M}+\mathrm{H}]^{+}$de $\mathrm{m} / \mathrm{z} 208,0$, correspondente a massa molecular de 207,0 (FIG. 10). A análise por MS da solução padrão de PCA gerou igual espectro MS. Também foi observada a razão $\mathrm{m} / \mathrm{z} 229,9$, devido ao aduto de sódio $[\mathrm{M}+\mathrm{Na}]^{+}$. A presença de adutos de sódio é bem conhecida em espectrometria de massas devido ao uso corrente de recipientes em vidro para os solventes. No presente estudo, a presença destes adutos de sódio também podem ser devido ao uso de uma solução de $\mathrm{NaOH}$ para dissolução do AF em água.

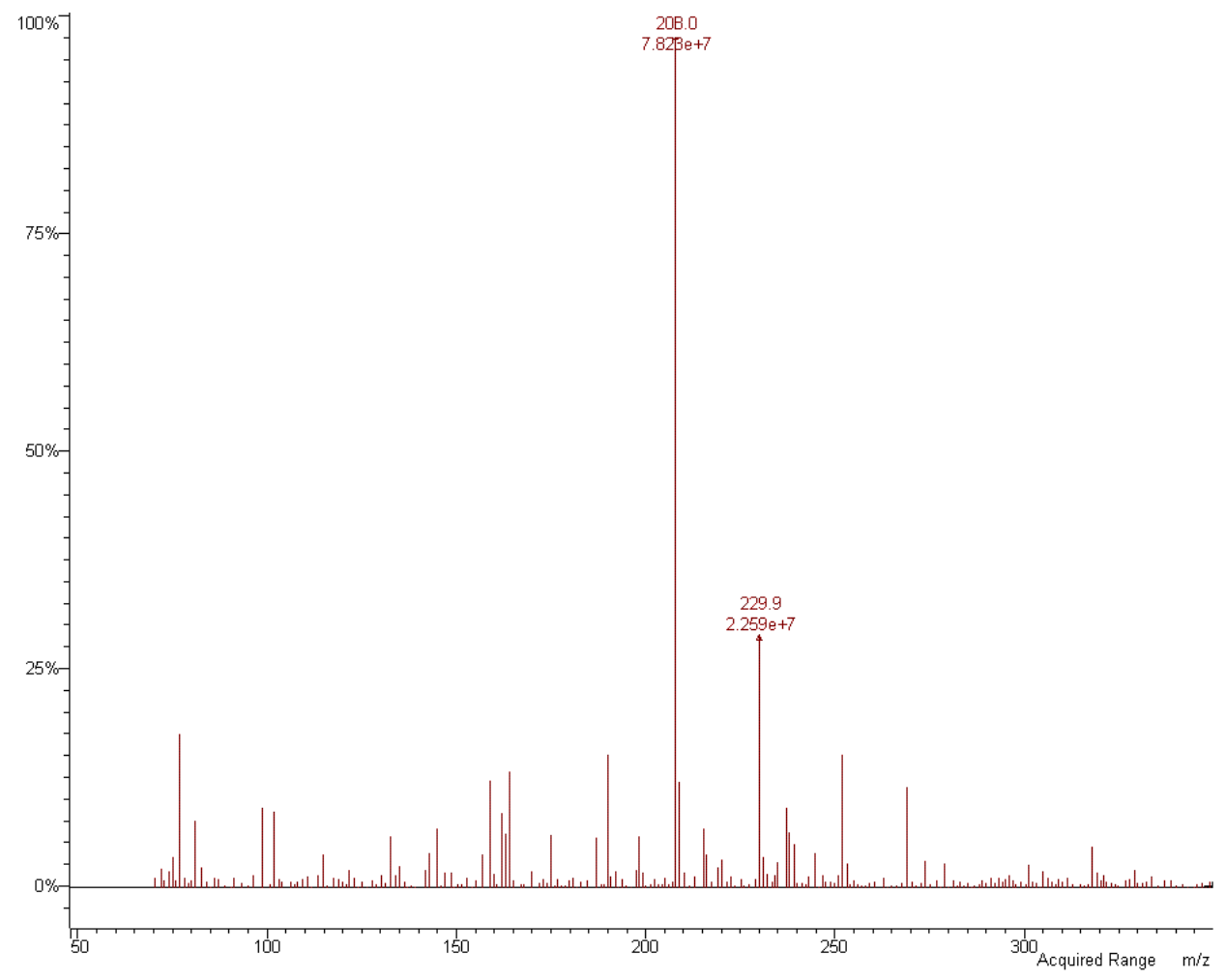

FIGURA 10. Espectro de massas $\left(\mathrm{ESI}^{+}\right)$do produto de degradação eluído com $\operatorname{tr}=13,2 \mathrm{~min}$. 
A fragmentação do padrão de PCA permitiu a comparação de seus fragmentos $\mathrm{MS}^{2}$ com os fragmentos do produto de degradação com $\operatorname{tr}=13,2 \mathrm{~min}$. Diferentes energias de ionização foram testadas $(15,20,25,30$ e 35V), gerando diversos fragmentos. O íon de $\mathrm{m} / \mathrm{z}=208,0$ foi selecionado e analisado por MS em sequência $\left(\mathrm{MS}^{2}\right)$ no intervalo de 100 a $210 \mathrm{~m} / \mathrm{z}$ com $15 \mathrm{~V}$, como mostrado na FIG. 11. O fragmento inicial ainda era visível com uma alta energia de 35V. Um perfil de fragmentação similar foi encontrado para a solução padrão de PCA e o produto de degradação ( $\operatorname{tr}=13,2 \mathrm{~min}$ ). Deste experimento pode-se inferir que 0 íon de $\mathrm{m} / \mathrm{z}$ 189,8 e 161,9, fragmentos do íon 208,0 [M+H $]^{+}$, referem-se a perda de água $\left[\mathrm{M}+\mathrm{H}-\mathrm{H}_{2} \mathrm{O}\right]^{+}$e descarboxilação $[\mathrm{M}+\mathrm{H}-\mathrm{HCOOH}]^{+}$, respectivamente.

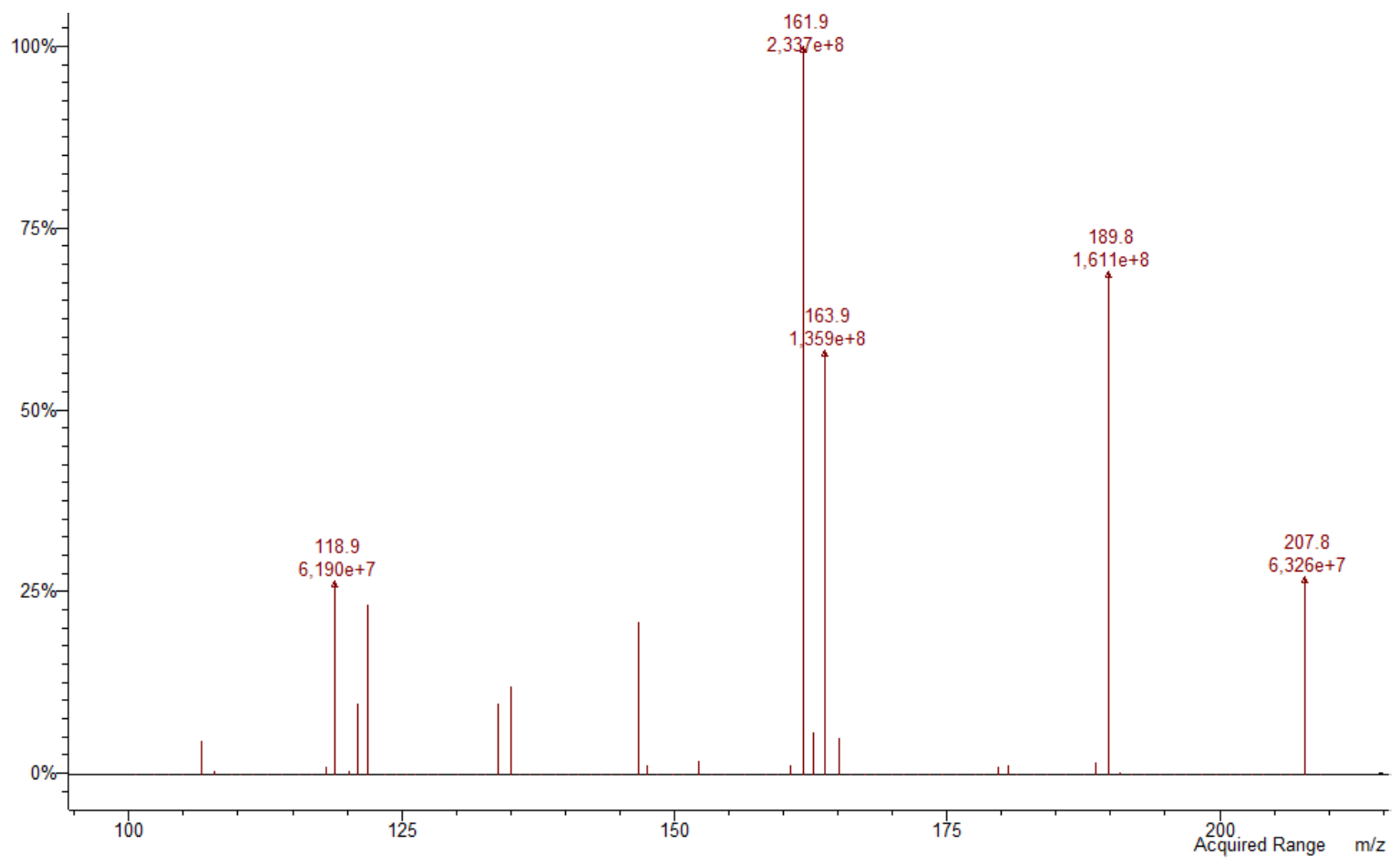

FIGURA 11. Espectro de massas em sequência $\left(\mathrm{MS}^{2}-E S I^{+}\right)$do produto de degradação eluído com tr = 13,2 $\min$.

A análise por espectrometria de massas de alta resolução (HRMS) do produto de degradação ( $\operatorname{tr}=13,2 \mathrm{~min}$ ) com ionização em modo positivo confirmou o resultado da MS, ou seja, um íon $[\mathrm{M}+\mathrm{H}]^{+}$de $\mathrm{m} / \mathrm{z} 208,0464$, correspondendo a 
uma fórmula bruta de $\mathrm{C}_{7} \mathrm{H}_{6} \mathrm{~N}_{5} \mathrm{O}_{3}$ (FIG. 12) (TAB. 8). Com base nestas informações pode-se verificar a identidade deste produto de degradação.

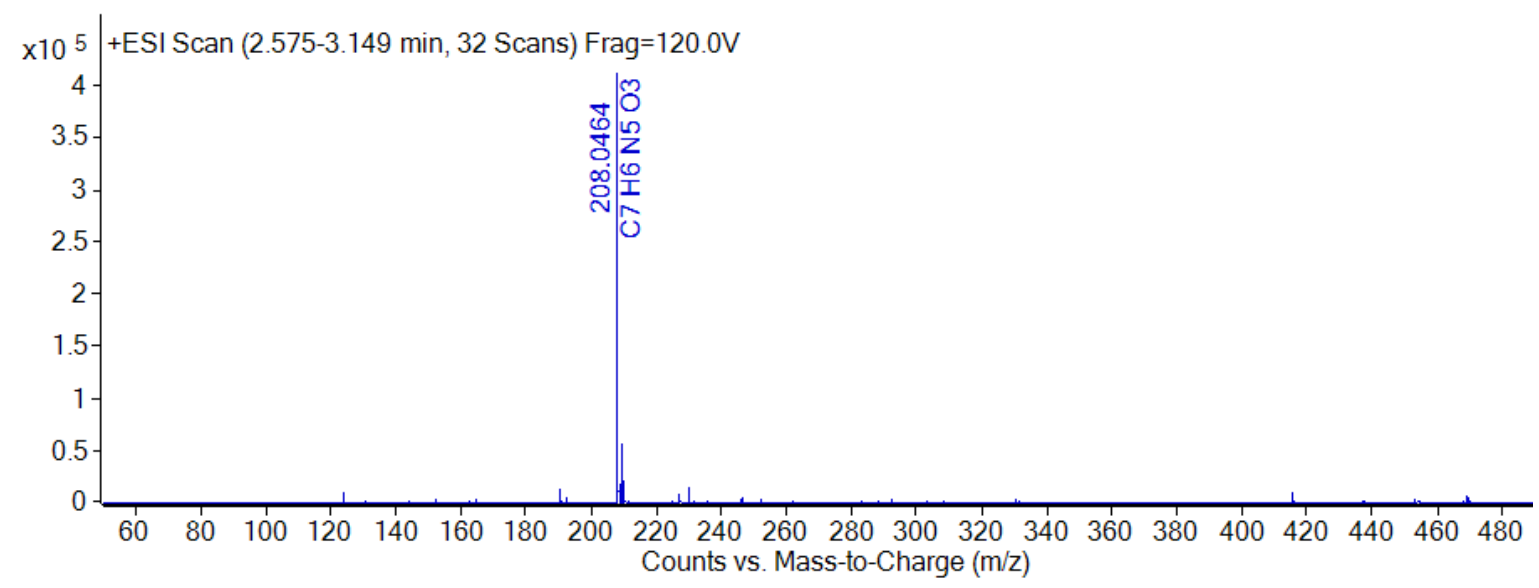

FIGURA 12. Espectro de massas HRMS $\left(\mathrm{ESI}^{+}\right)$do produto de degradação eluído com $\operatorname{tr}=13,2 \mathrm{~min}$.

Uma clivagem da ligação $\mathrm{C}_{9}-\mathrm{N}_{10}$ da molécula de $\mathrm{AF}$ resultou assim, na formação do produto de degradação 6-carboxipterina (PCA), correspondente ao pico 3 (FIG. 8).

\section{Pico cromatográfico 4}

Os perfis cromatográficos de uma solução aquosa de AF irradiadas a partir de $1 \mathrm{kGy}$, evidenciaram a presença de um produto de degradação com $\mathrm{tr}=$ 17,2 min (FIG. 8B,C,D, pico 4). Este radioproduto foi confrontado com os demais produtos fotolíticos conhecidos do AF. Uma solução padrão do composto p-aminobenzoil-L-ácido glutâmico (pABGA) com o método 2 resultou na eluição deste composto no mesmo tr deste produto de degradação do AF. Os espectros UV do padrão de pABGA e do produto de degradação eluído a 17,2 min apresentaram espectros sobrepostos (FIG. 13). Estes resultados deram fortes indícios de tratar-se do mesmo produto. 


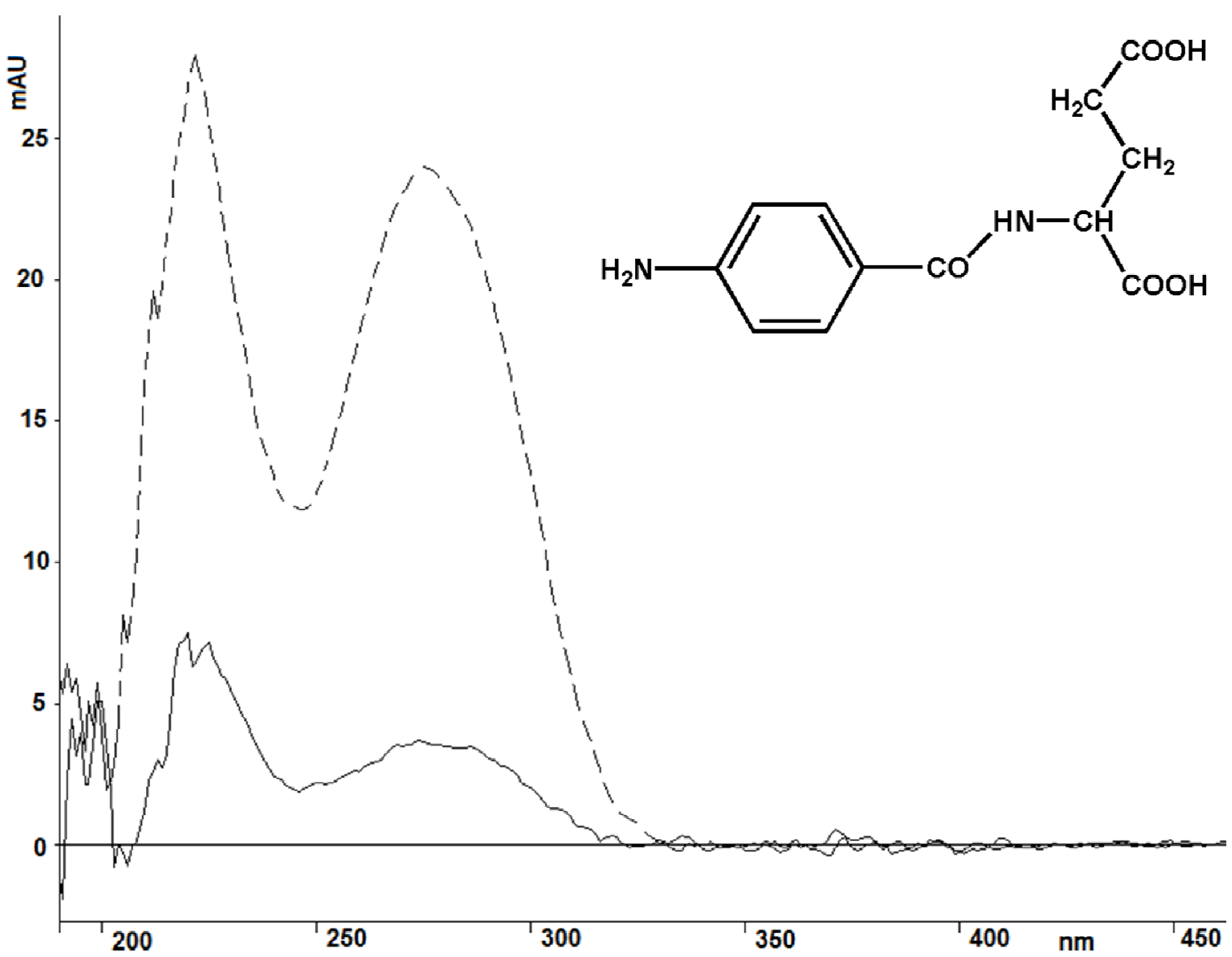

FIGURA 13. Estrutura química e espectro UV do pABGA (linha pontilhada) sobreposto ao produto de degradação eluído com tr = 17,2 min (linha contínua).

A confirmação desta informação se deu com o uso de MS/ESI+. Esta análise gerou $\mathrm{O}$ íon $[\mathrm{M}+\mathrm{H}]^{+}$de $\mathrm{m} / \mathrm{z} 267,0$, correpondente a massa molecular de 266,0 (FIG. 14), sugerindo uma perda de 175 da molécula de AF. Também foi observada a razão $\mathrm{m} / \mathrm{z} 289,0$, novamente devido a um aduto de sódio $[\mathrm{M}+\mathrm{Na}]^{+}$. A análise por MS da solução padrão de pABGA gerou igual espectro MS. Além disso, no mesmo espectro de massas, observou-se uma $\mathrm{m} / \mathrm{z}=119,9$, provavelmente decorrente da perda do ácido glutâmico $(\mathrm{m} / \mathrm{z} 147)$ da molécula de PABGA. 


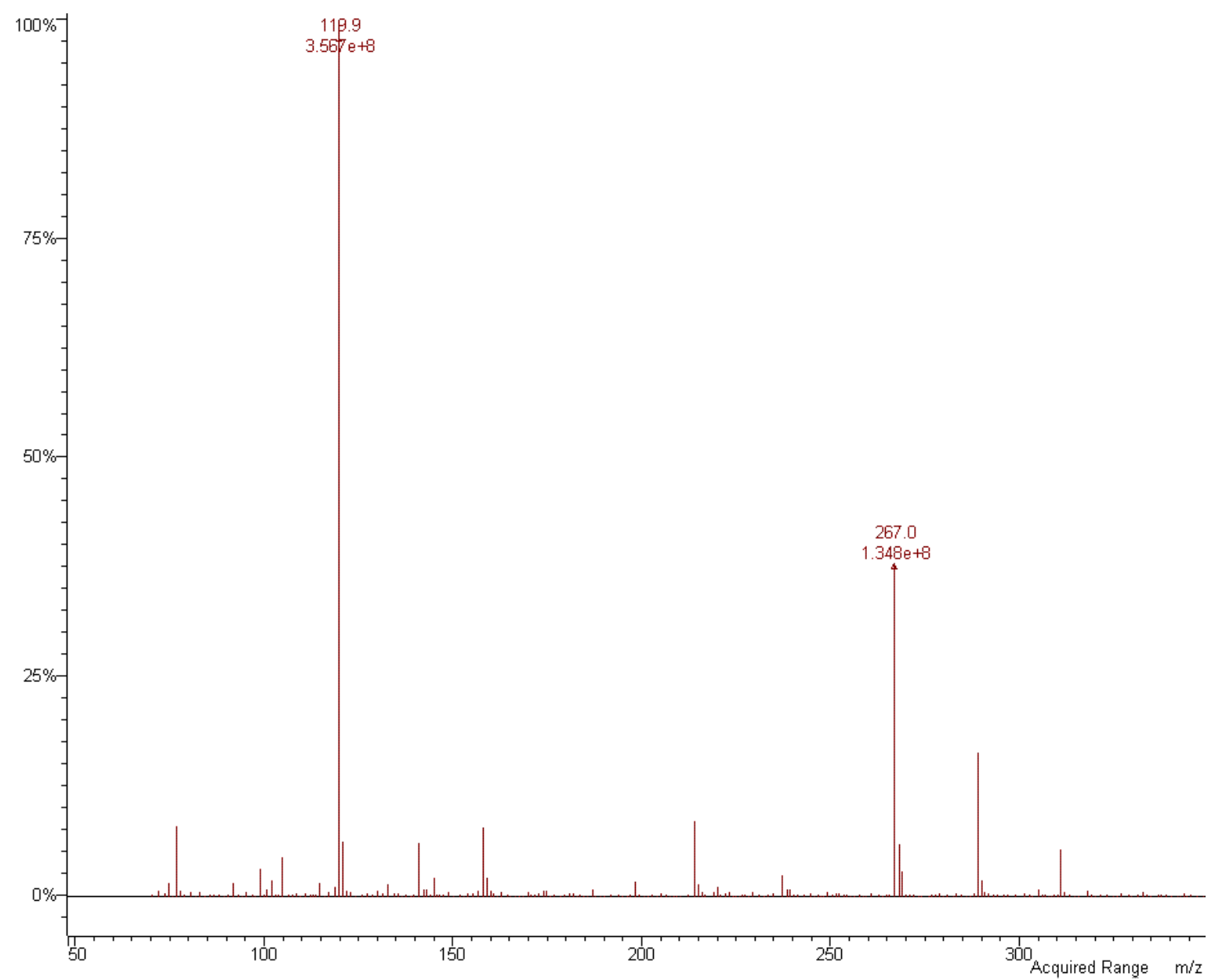

FIGURA 14. Espectro de massas $\left(\mathrm{ESI}^{+}\right)$do produto de degradação eluído com tr $=17,2 \mathrm{~min}$.

Com o objetivo de se ter mais informações sobre este composto, o íon de $\mathrm{m} / \mathrm{z}=267,0$ foi selecionado e analisado por MS em sequência $\left(\mathrm{MS}^{2}\right)$ com diferentes energias de ionização (15, 20, 25, 30 e 35V) no intervalo de 100 a 275 $\mathrm{m} / \mathrm{z}$. Uma energia de ionização de $15 \mathrm{~V}$ gerou uma fragmentação importante do fragmento inicial (FIG. 15). Percebeu-se que o íon $\mathrm{m} / \mathrm{z} 267$ fragmentou preferencialmente no íon de m/z 119,9, sugerindo a quebra da porção p-aminobenzoil do AF. Um perfil de fragmentação similar foi encontrado para a solução padrão de pABGA. Assim como o AF, o pABGA apresenta um ponto de 
fragilidade entre a porção glutamato e a porção p-aminobenzóico com ionização positiva.

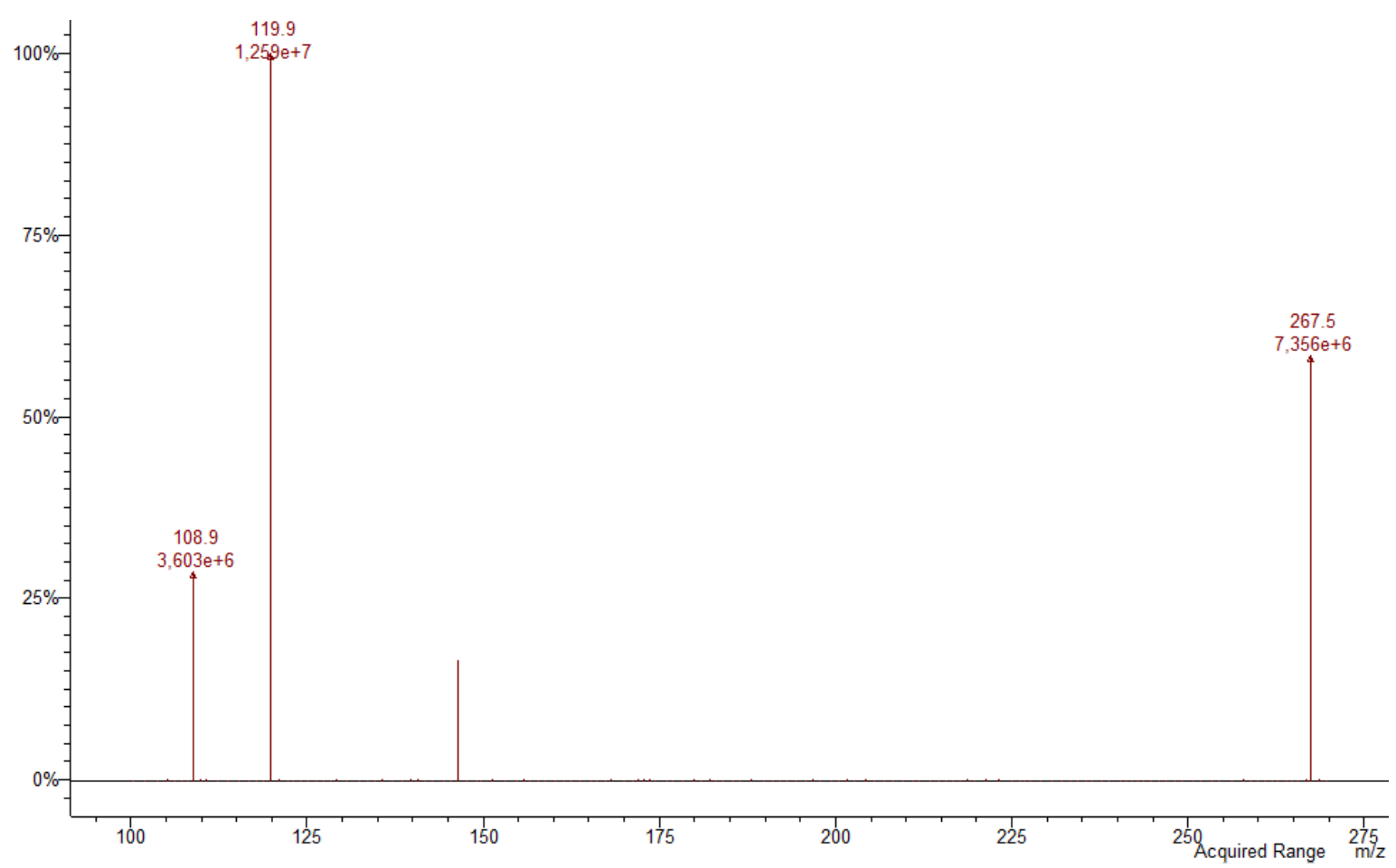

FIGURA 15. Espectro de massas em sequência $\left(\mathrm{MS}^{2}-\mathrm{ESI}^{+}\right)$do produto de degradação eluído com tr = 17,2 min.

A análise de HRMS com ionização em modo positivo confirmou a presença do íon $[\mathrm{M}+\mathrm{H}]^{+}$de $\mathrm{m} / \mathrm{z} 267,0992$. A HRMS permitiu a atribuição de uma fórmula bruta de $\mathrm{C}_{12} \mathrm{H}_{14} \mathrm{~N}_{2} \mathrm{O}_{5}$ (FIG. 16) (TAB. 8), coincidente ao composto pABGA. Todas estas informações permitiram confirmar a identidade do composto com $\mathrm{tr}=$ 17,2 min como sendo o pABGA. 


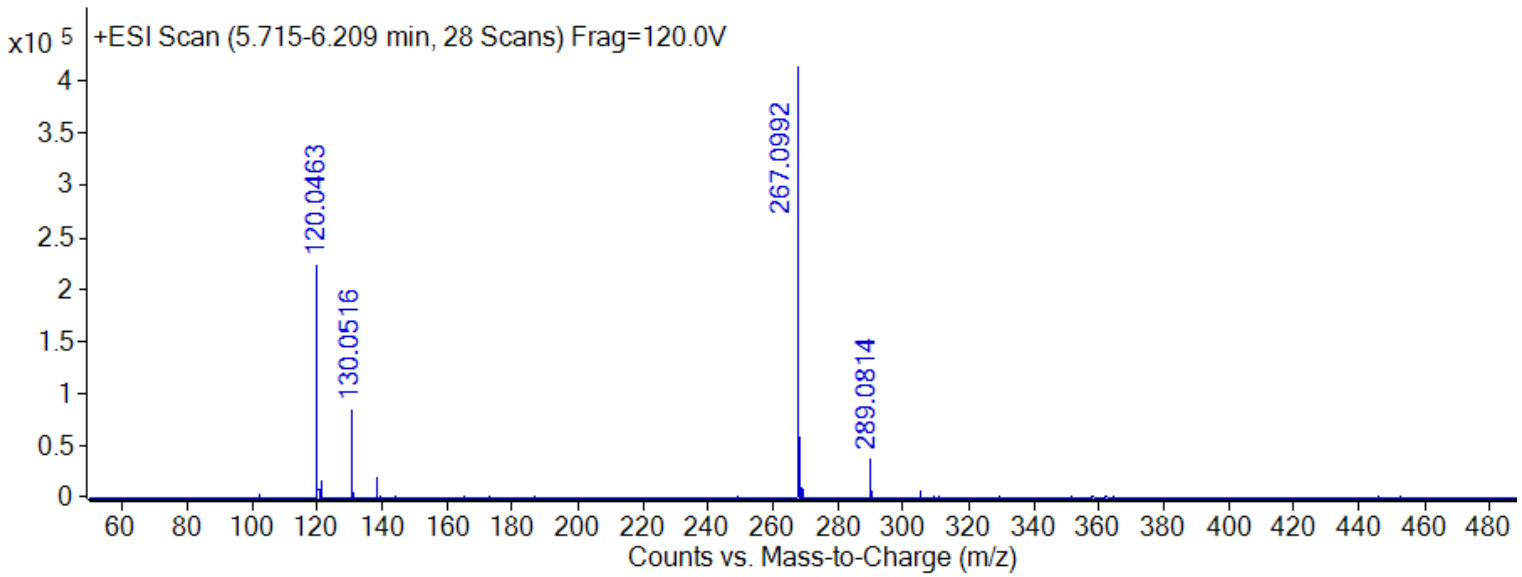

FIGURA 16. Espectro de massas HRMS $\left(\mathrm{ESI}^{+}\right)$do produto de degradação eluído com $\operatorname{tr}=17,2 \mathrm{~min}$.

Igualmente, traços de $\mathrm{m} / \mathrm{z}$ 138,0 $[\mathrm{M}+\mathrm{H}]^{+}$foram encontrados em soluções aquosas de AF (FIG. 17). A perda simultânea do grupo pterina e da molécula de ácido glutâmico da molécula inicial do $A F$ deu origem à molécula do ácido p-aminobenzóico (PABA).

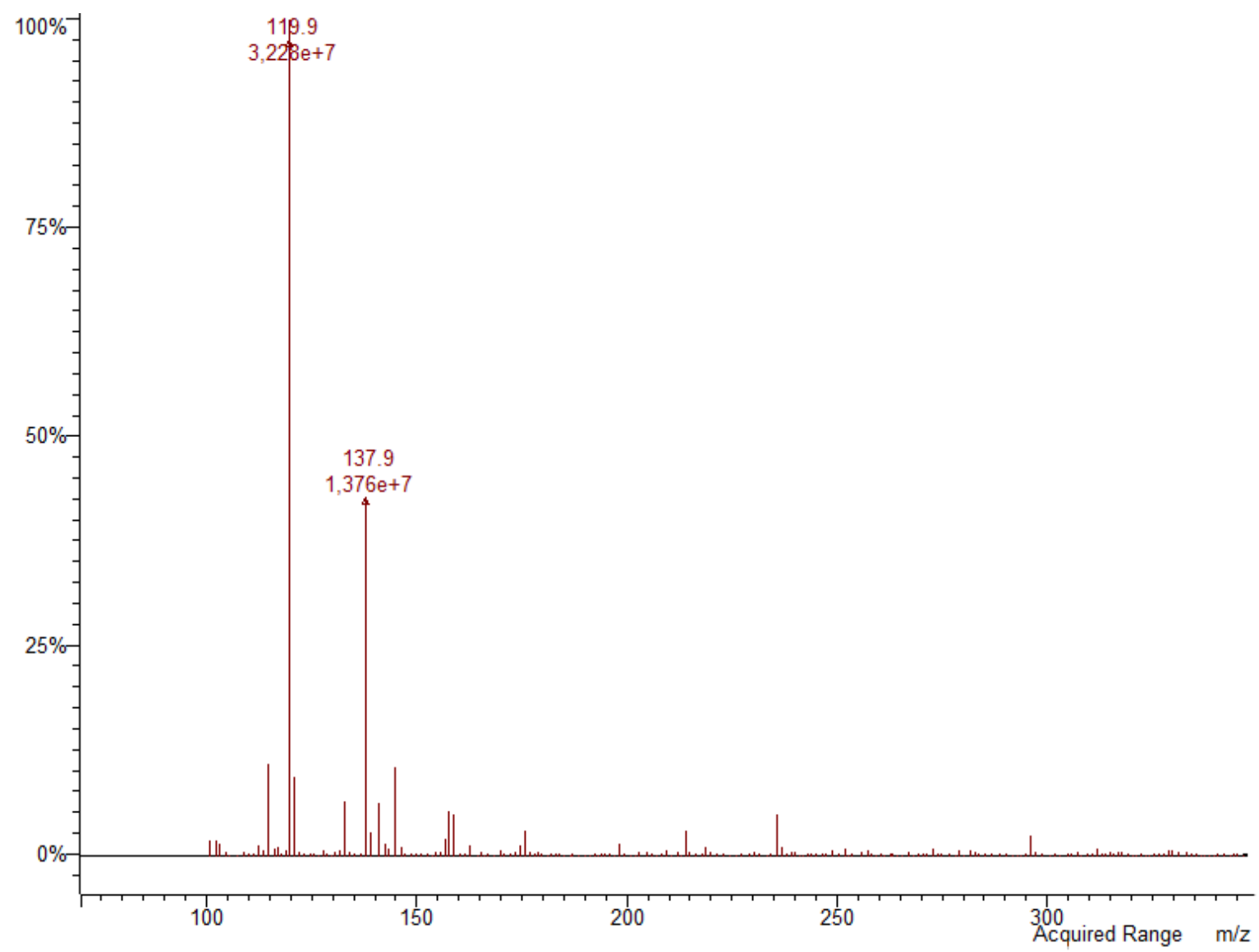

FIGURA 17. Espectro de massas $\left(E S I^{+}\right)$do PABA $[\mathrm{M}+\mathrm{H}]^{+}$. 


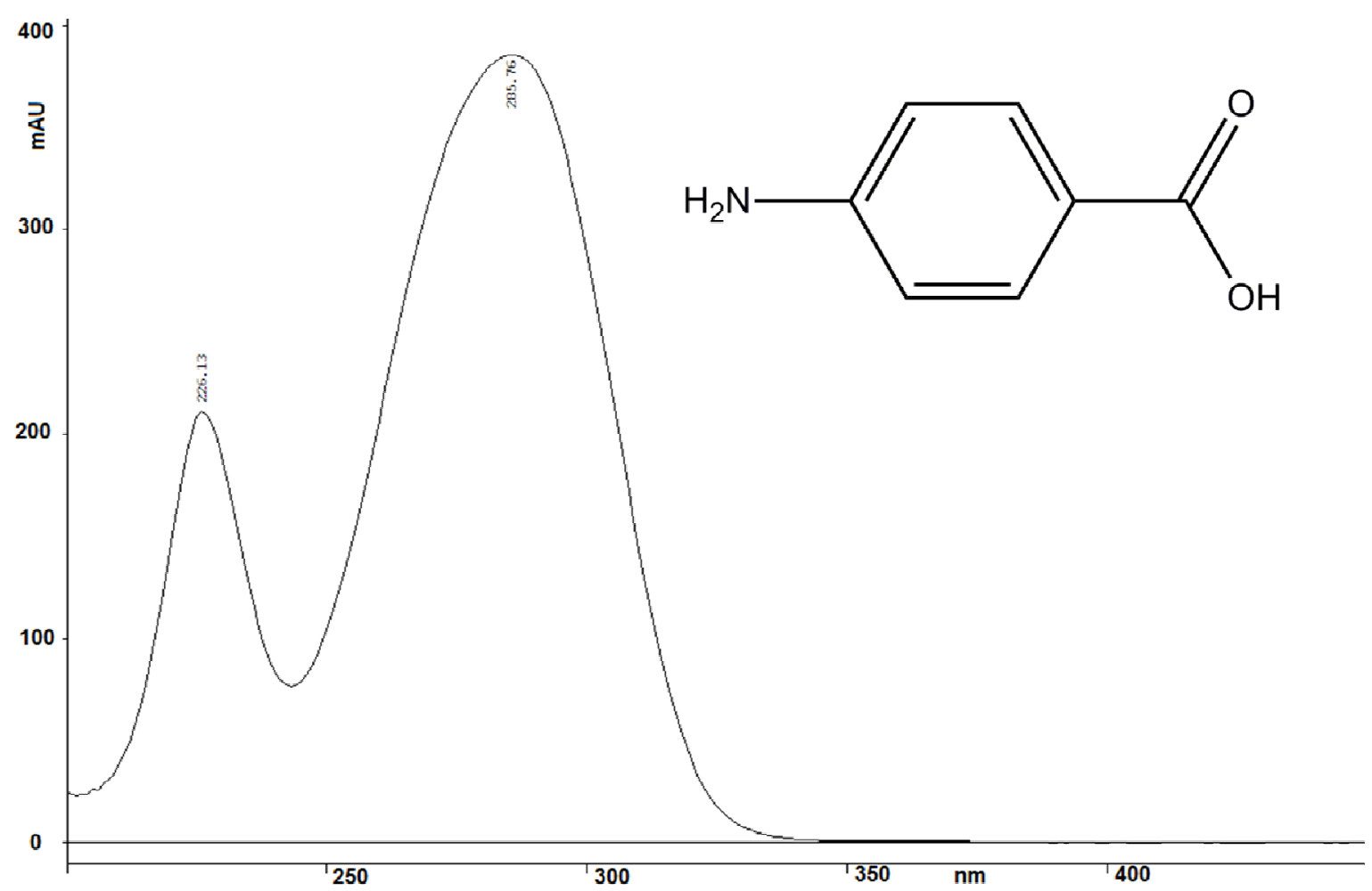

FIGURA 18. Estrutura química e espectro UV do PABA.

Não foi possível a comparação do espectro UV do padrão de PABA uma vez que o sinal cromatográfico era muito pequeno (FIG. 18). Assim a confirmação da presença do produto de degradação ácido p-aminobenzóico se deu por espectrometria de massas (FIG. 19) (TAB. 8).

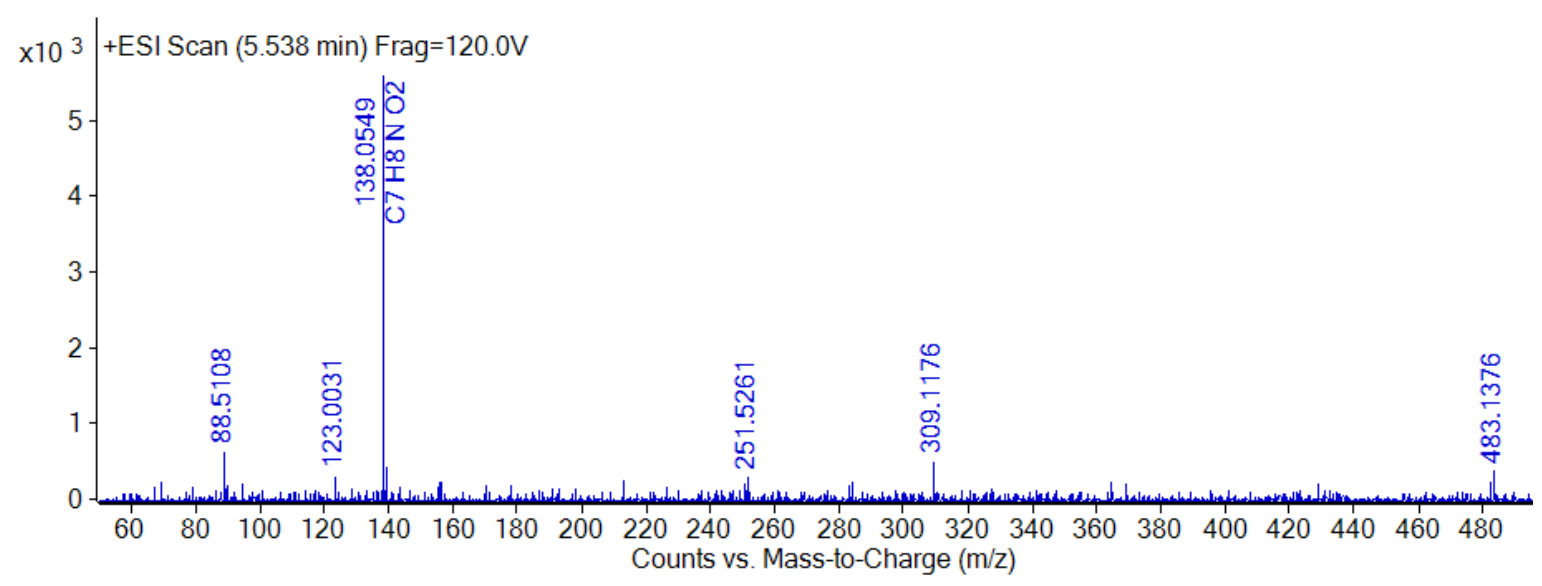

FIGURA 19. Espectro de massas HRMS $\left(\mathrm{ESI}^{+}\right)$do PABA $[\mathrm{M}+\mathrm{H}]^{+}$. 


\section{Pico cromatográfico 1}

Além destes produtos de degradação já conhecidos, outros picos também foram observados nos cromatogramas LC/UV/MS (FIG. 8). O produto de degradação encontrado no $\operatorname{tr}=6,9$ min (FIG. 8B, pico 1) não apresentou dados cromatográficos e/ou espectrométricos comparáveis a nenhum fotoproduto do $\mathrm{AF}$ conhecido.

A análise por LC/MS indicou a presença de um íon com $\mathrm{m} / \mathrm{z}=180,0$ $[\mathrm{M}+\mathrm{H}]^{+}$(FIG. 20). No mesmo espectro MS também observou-se a presença de um íon $\mathrm{m} / \mathrm{z}=198,0$, provavelmente devido a uma molécula de $\mathrm{H}_{2} \mathrm{O}\left[\mathrm{M}+\mathrm{H}+\mathrm{H}_{2} \mathrm{O}\right]^{+}$.

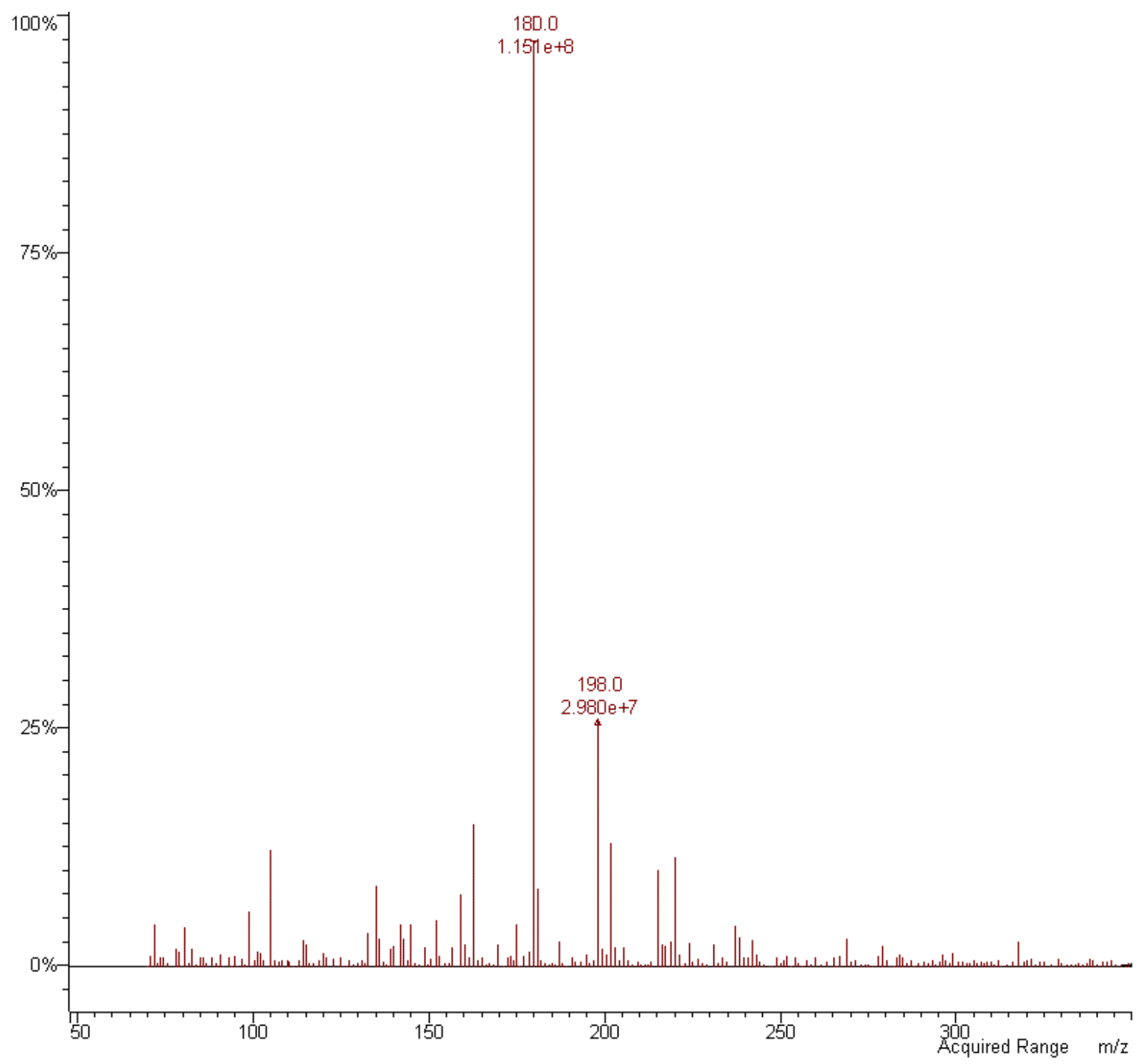

FIGURA 20. Espectro de massas $\left(\mathrm{ESI}^{+}\right)$do produto de degradação eluído com $\operatorname{tr}=6,9 \mathrm{~min}$. 
A fragmentação em $\mathrm{MS}^{2}$ dos fotoprodutos do $\mathrm{AF}$ permitiu a comparação dos fragmentos obtidos para determinar que partes da molécula de AF estariam presentes nos novos produtos de degradação encontrados. Além disso, sugeriu as transformações sofridas por estes produtos logo dos tratamentos estudados, inclusive a irradiação.

O íon de $\mathrm{m} / \mathrm{z}=180,0$ foi selecionado e analisado por MS em sequência $\left(\mathrm{MS}^{2}\right)$ com energias de ionização na faixa de $10 \mathrm{~V}$ a $40 \mathrm{~V}$ no intervalo de 80 a $200 \mathrm{~m} / \mathrm{z}$. Com uma ionização (20V) tanto em modo positivo quanto negativo observamos os fragmentos 107,7 e 134,8, característicos do grupamento pteridina (FIG. 21). Com base nestas informações supôs-se a presença da função pteridina neste produto de degradação. Uma diferença $\mathrm{m} / \mathrm{z}$ de 16 entre o íon 179 e a pterina ( $\mathrm{m} / \mathrm{z}$ 163) poderia propor uma transformação da mesma com adição de oxigênio. A única possibilidade de oxidação que permitiria a ruptura do AF decorrente da irradiação é a ligação C-C entre o ciclo pteridina e a porção p-aminobenzóico, podendo corresponder desta forma à xantopterina (XA) (2amino-3,5-dihidropteridina-4,6-dione).

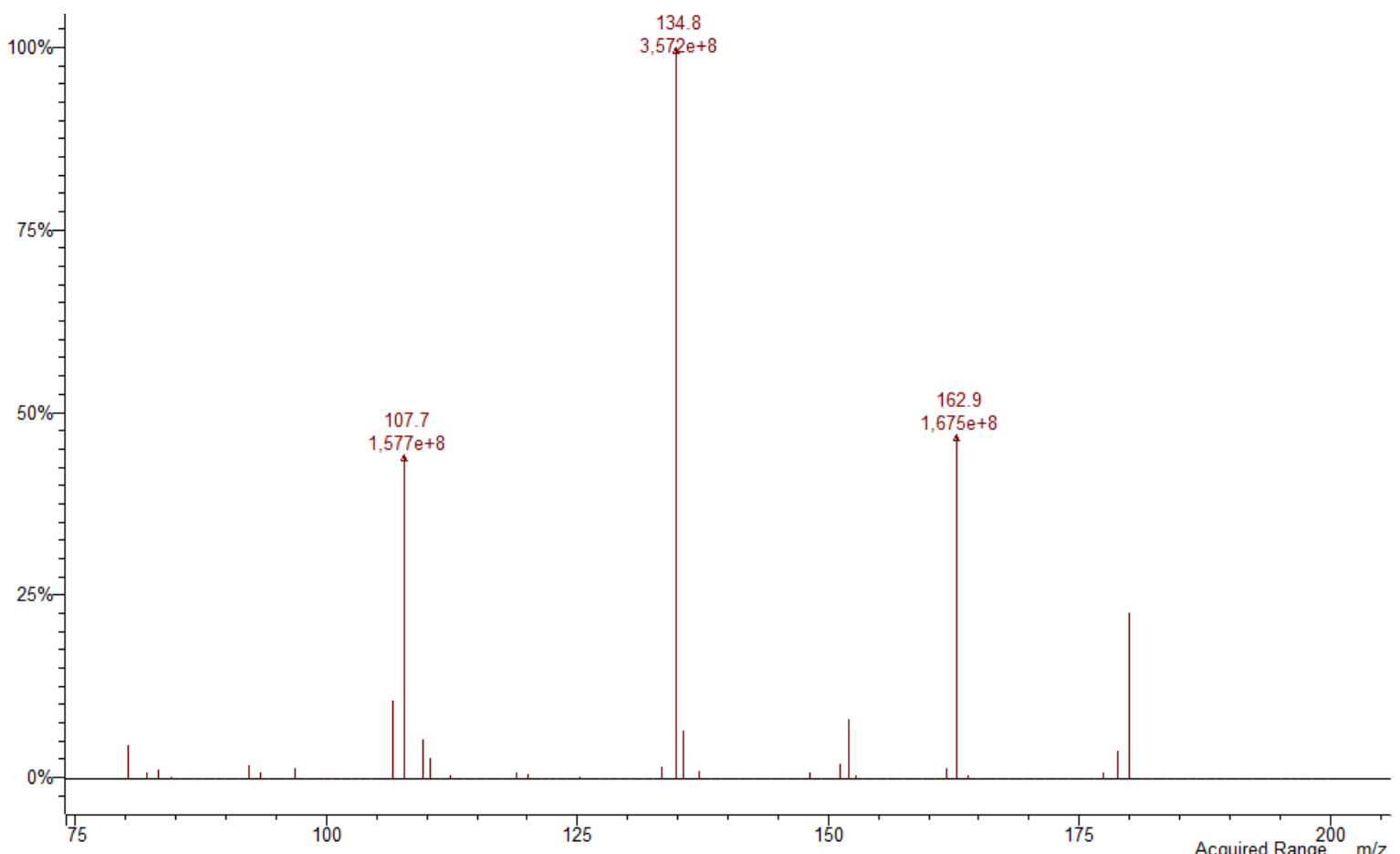

FIGURA 21. Espectro de massas em sequência $\left(\mathrm{MS}^{2}-\mathrm{ESI}^{+}\right)$do produto de degradação eluído com $\operatorname{tr}=6,9 \mathrm{~min}$. 
A análise por espectrometria de massas de alta resolução (HRMS) com ionização em modo positivo reafirmou a hipótese mostrada. Foi confirmada a presença do íon $[\mathrm{M}+\mathrm{H}]^{+}$de $\mathrm{m} / \mathrm{z}$ 180,0518 (FIG. 22) e a proposição de uma fórmula bruta correspondente a $\mathrm{C}_{6} \mathrm{H}_{6} \mathrm{~N}_{5} \mathrm{O}_{2}$, coincidente com a xantopterina (TAB. 8).

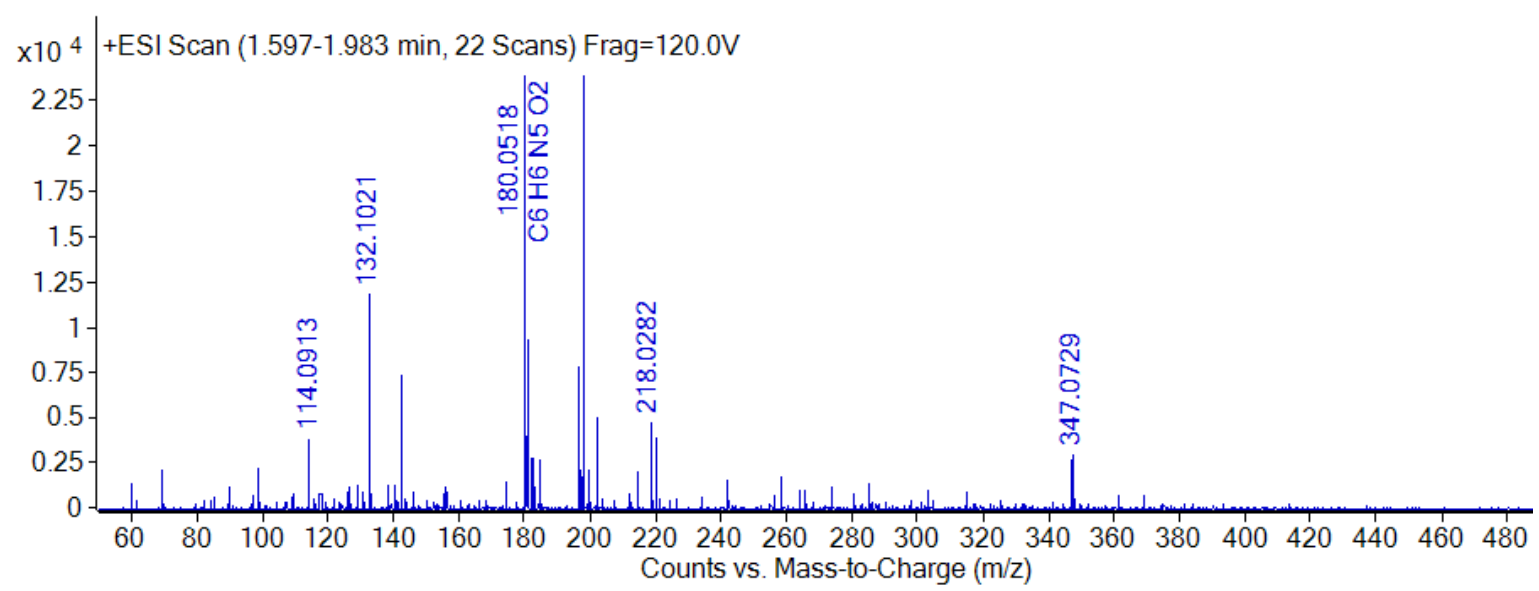

FIGURA 22. Espectro de massas HRMS $\left(\mathrm{ESI}^{+}\right)$do produto de degradação eluído com $\operatorname{tr}=6,9 \mathrm{~min}$.

Um padrão de XA (CAS 5979-01-1) foi adquirido e submetido às mesmas análises do produto de degradação em estudo ( $\operatorname{tr}=6,9 \mathrm{~min}$ ). Análises de MS e $M^{2}{ }^{2}$ foram realizadas com uma solução padrão de XA e os mesmos espectros $M S$ e $\mathrm{MS}^{2}$ foram encontrados, confirmando a identidade deste produto de degradação do AF. A injeção do padrão da XA com o método 2 resultou na eluição deste composto no mesmo tr deste produto de degradação do $\mathrm{AF}$ encontrado com $\operatorname{tr}=6,9 \mathrm{~min}$. $\mathrm{Na}$ avaliação dos espectros UV do padrão da XA e do produto de degradação eluído a 6,9 min, foram obtidos espectros que se superpõem (FIG. 23). 


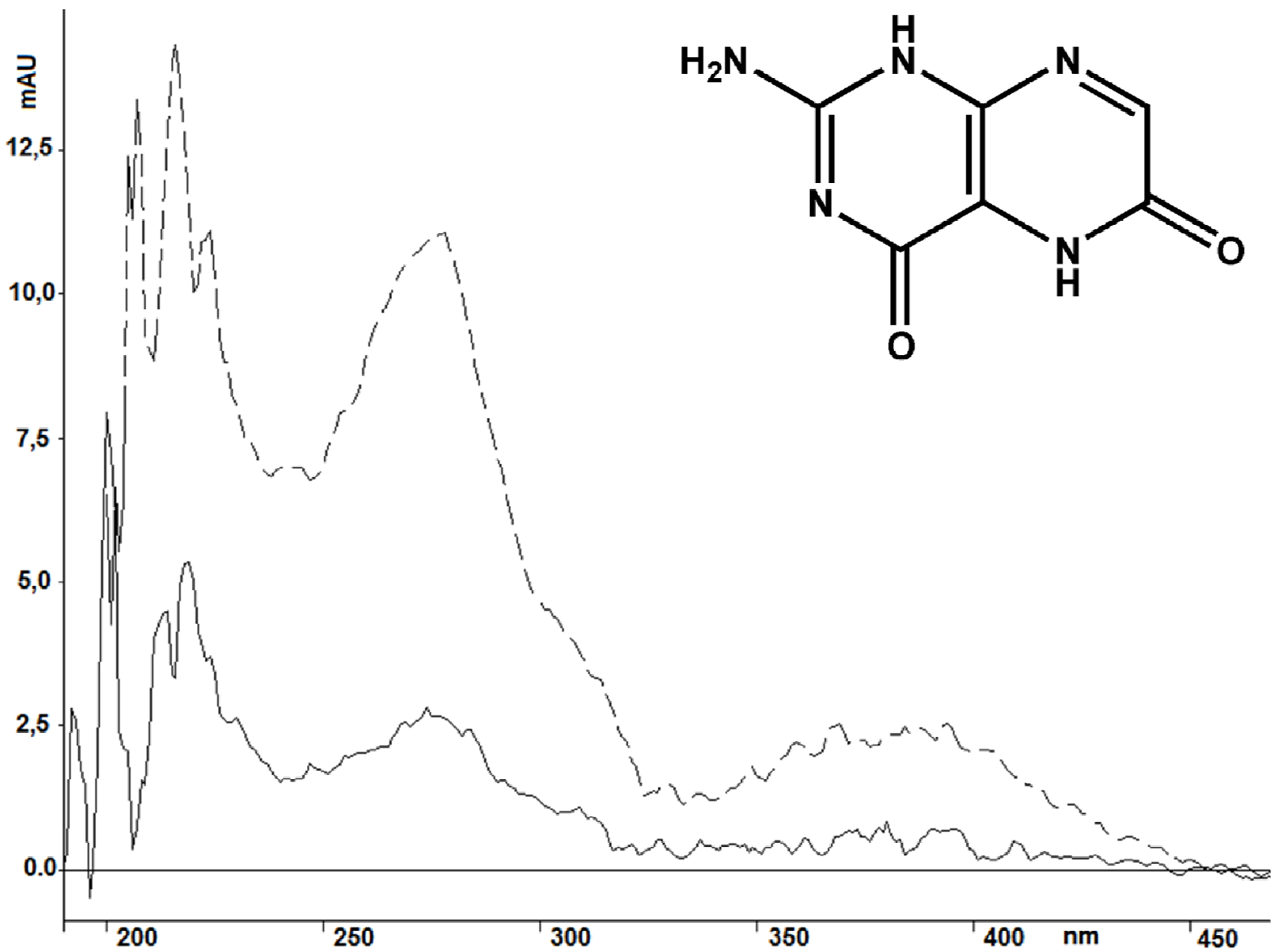

FIGURA 23. Estrutura química e espectro UV do XA (linha pontilhada) sobreposto ao produto de degradação eluído com tr =6,9 min (linha contínua).

\section{Pico cromatográfico 2}

O processamento por radiação (1 kGy) promoveu a formação de outro novo produto de degradação no $\operatorname{tr}=8,7 \mathrm{~min}$ (FIG. 8B, pico 2). Este novo composto não coincidiu com nenhum outro fotoproduto conhecido. A análise por LC/MS indicou a presença dos íons com m/z = 194,0 [M+H] $]^{+}$; 175,9 e 215,9 (FIG. 24). O íon $\mathrm{m} / \mathrm{z} 175,9$, provavelmente trata-se da perda de uma molécula de água $\left[\mathrm{M}+\mathrm{H}-\mathrm{H}_{2} \mathrm{O}\right]^{+}$e o íon m/z 215,9 deve tratar-se de um aduto de sódio $[\mathrm{M}+\mathrm{Na}]^{+}$. 


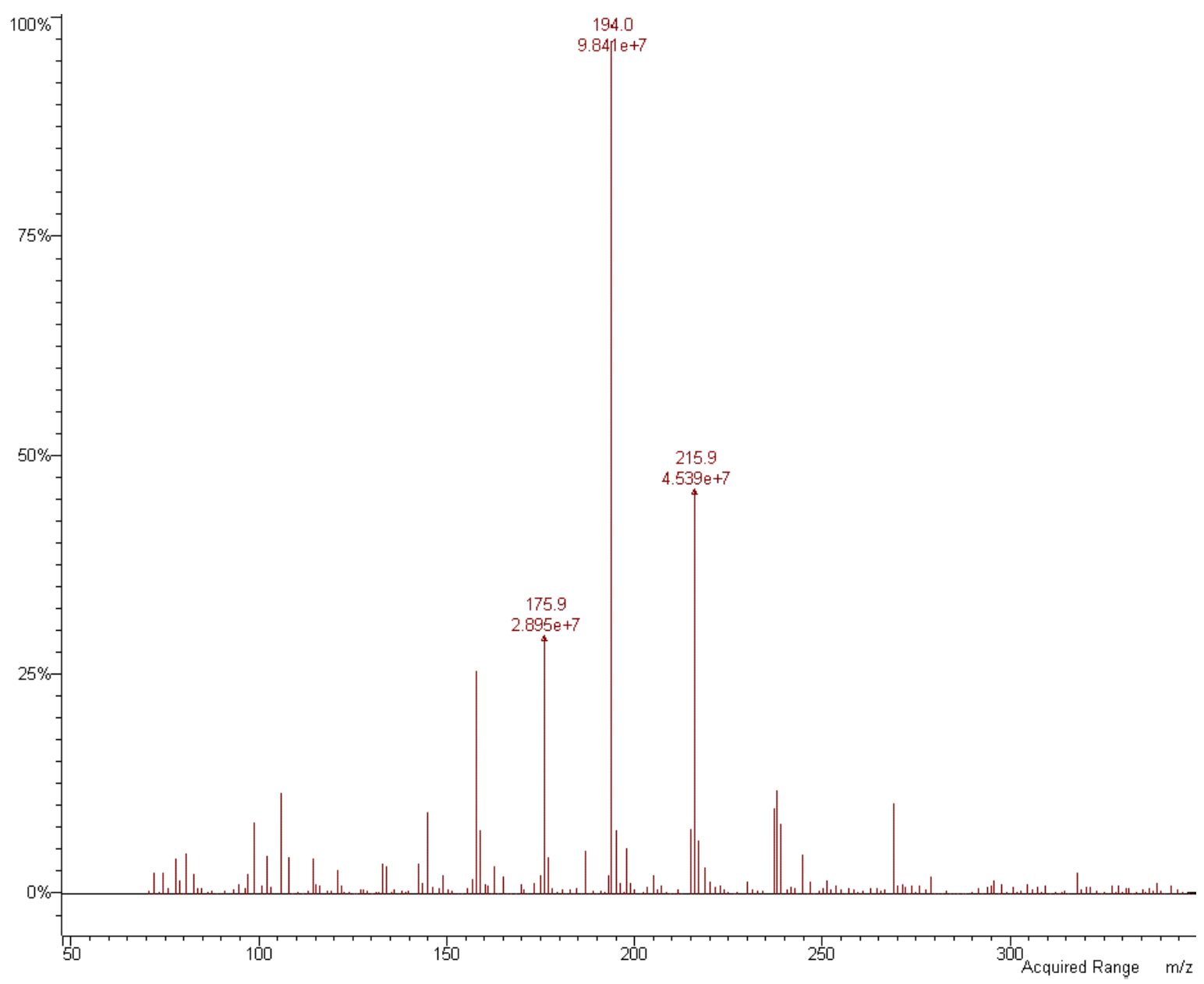

FIGURA 24. Espectro de massas $\left(\mathrm{ESI}^{+}\right)$do produto de degradação eluído com $\operatorname{tr}=8,7 \mathrm{~min}$.

A análise do íon $\mathrm{m} / \mathrm{z}=194,0$ por $\mathrm{MS}^{2}$ com energia de ionização de $15 \mathrm{~V}$ promoveu a formação dos fragmentos de $\mathrm{m} / \mathrm{z}$ 107,8 e 134,0, característicos da pteridina (FIG. 25). Assim, novamente esta parte da molécula de AF estaria presente neste produto de degradação. Uma diferença de $30 \mathrm{~m} / \mathrm{z}$ em relação à pteridina ( $\mathrm{m} / \mathrm{z}$ 163), característica de uma função $\mathrm{CH}_{2} \mathrm{O}$, propôs uma redução no carbono da pteridina ligado à porção do ácido $p$-aminobenzóico. 


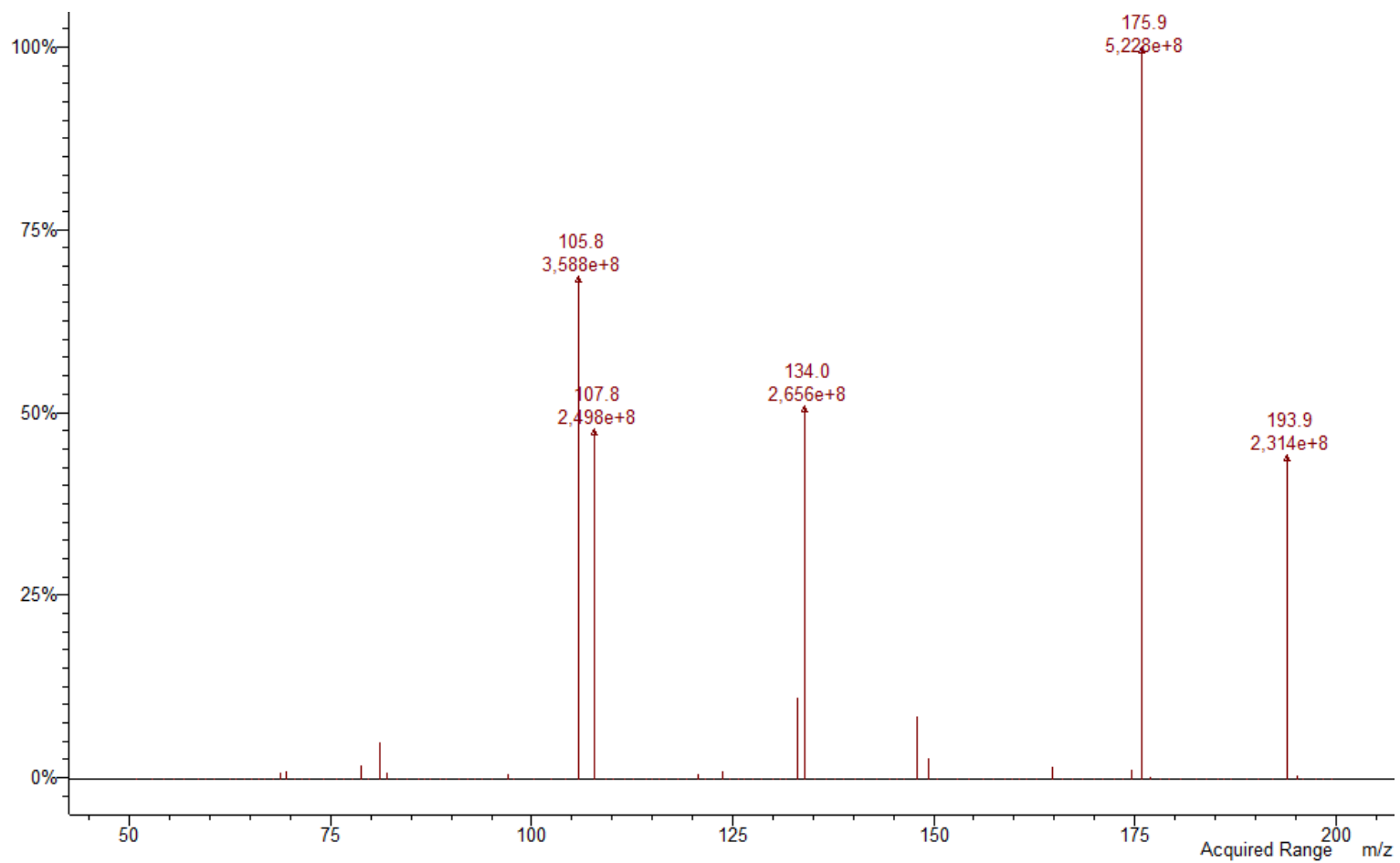

FIGURA 25. Espectro de massas em sequência $\left(\mathrm{MS}^{2}-\mathrm{ESI}^{+}\right)$do produto de degradação eluído com tr = 8,7 min.

Os resultados de HRMS com ionização em modo positivo confirmaram o dado de m/z encontrado por LC/MS $\left(\mathrm{m} / \mathrm{z}=194,0676[\mathrm{M}+\mathrm{H}]^{+}\right)$e indicaram uma possível fórmula molecular de $\mathrm{C}_{7} \mathrm{H}_{7} \mathrm{~N}_{5} \mathrm{O}_{2}$. Igualmente na análise por HRMS, o íon de $\mathrm{m} / \mathrm{z} 216,0491[\mathrm{M}+\mathrm{Na}]^{+}$também foi encontrado. Com bases nestes resultados, poderia tratar-se do composto 2-amino-6-(hidroximetil)pteridina-4(1H)-one (AHMP) (FIG. 26) (TAB. 8).

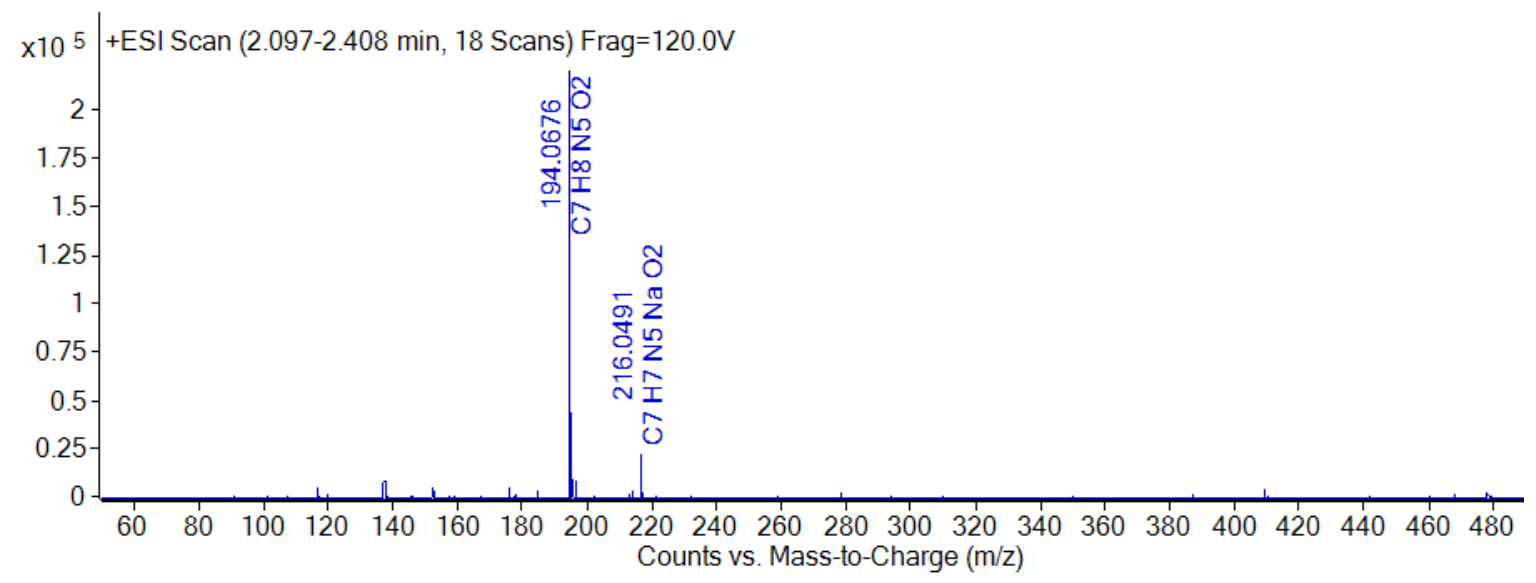

FIGURA 26. Espectro de massas HRMS $\left(\mathrm{ESI}^{+}\right)$do produto de degradação eluído com $\operatorname{tr}=8,7 \mathrm{~min}$. 
Análises de $M S$ e $M^{2}$ de uma solução padrão de AHMP comercialmente disponível (CAS 712-29-8) confirmaram os resultados cromatográficos e espectrométricos obtidos. Foram encontramos os mesmos espectros MS e $\mathrm{MS}^{2}$. Igualmente, uma solução padrão de AHMP teve mesmo tr do produto de degradação com $\operatorname{tr}=8,7$ min. Os espectros UV de ambos também se sobreporam (FIG. 27).

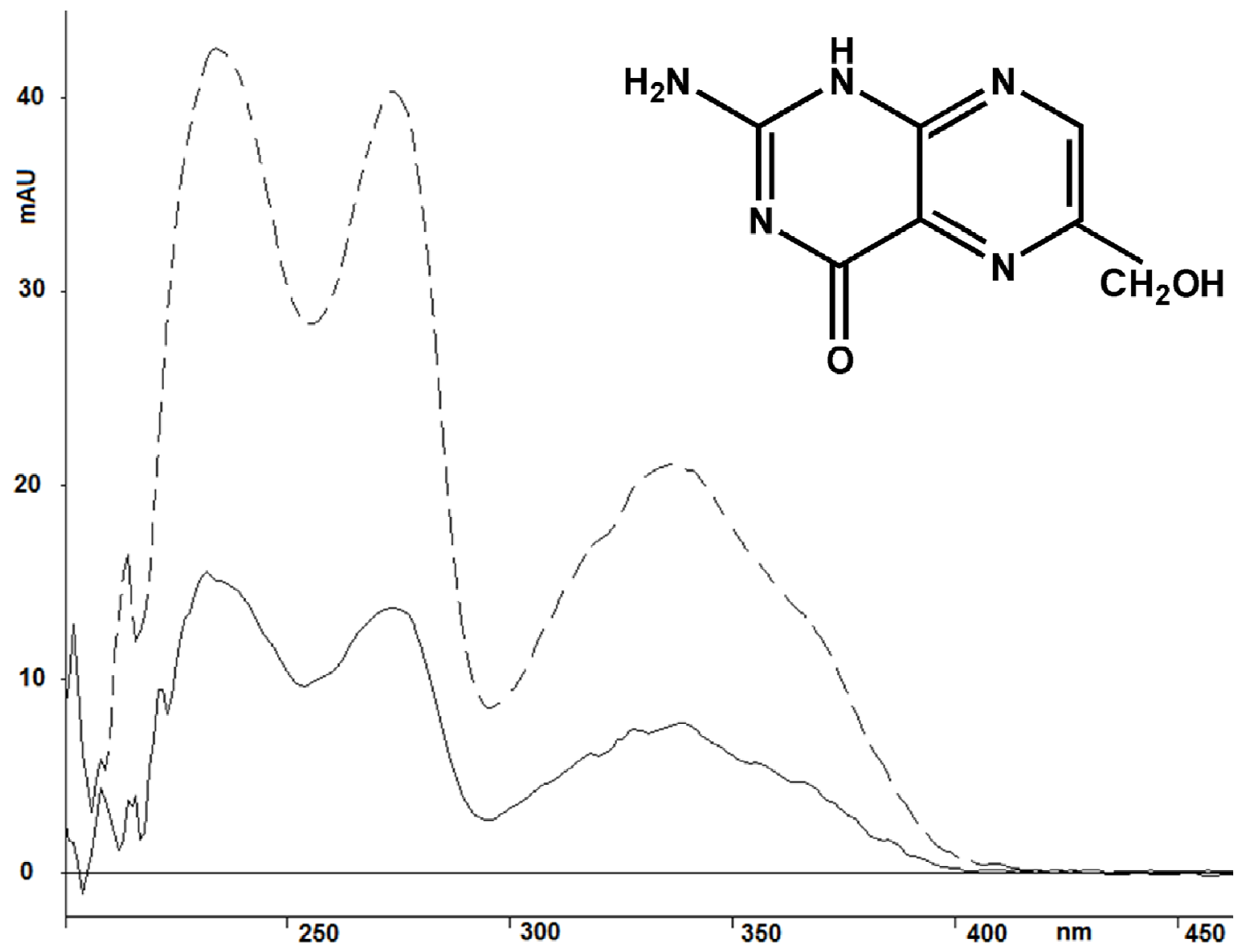

FIGURA 27. Estrutura química e espectro UV do AHMP (linha pontilhada) sobreposto ao produto de degradação eluído com $\mathrm{tr}=8,7 \mathrm{~min}$ (linha contínua).

\section{Pico cromatográfico 7}

Um produto de degradação do AF também foi encontrado em soluções de $A F$ irradiadas com baixas doses de radiação (até $1 \mathrm{kGy}$ ) no $\mathrm{tr}=45,8 \mathrm{~min}$ (FIG. $8 \mathrm{~B}$, pico 7). Nenhuma informação sobre este produto (tr, espectro UV, MS, MS ${ }^{2}$, 
HRMS) foi coincidente com os fotoprodutos do AF conhecidos, fato que levou a pensar em um terceiro novo radioproduto formado.

O espectro MS obtido na análise por LC/MS indicou a presença dos íons com m/z = 149,9; 279,0 e 297,0 [M+H] ${ }^{+}$(FIG. 28); também foi verificada a presença de $\mathrm{m} / \mathrm{z} 319,0$. O íon de $\mathrm{m} / \mathrm{z} 279,0$ poderia tratar-se de $\left[\mathrm{M}+\mathrm{H}-\mathrm{H}_{2} \mathrm{O}\right]^{+}$e o íon de $\mathrm{m} / \mathrm{z} 319,0$ poderia tratar-se novamente de um aduto de sódio $[\mathrm{M}+\mathrm{Na}]^{+}$.

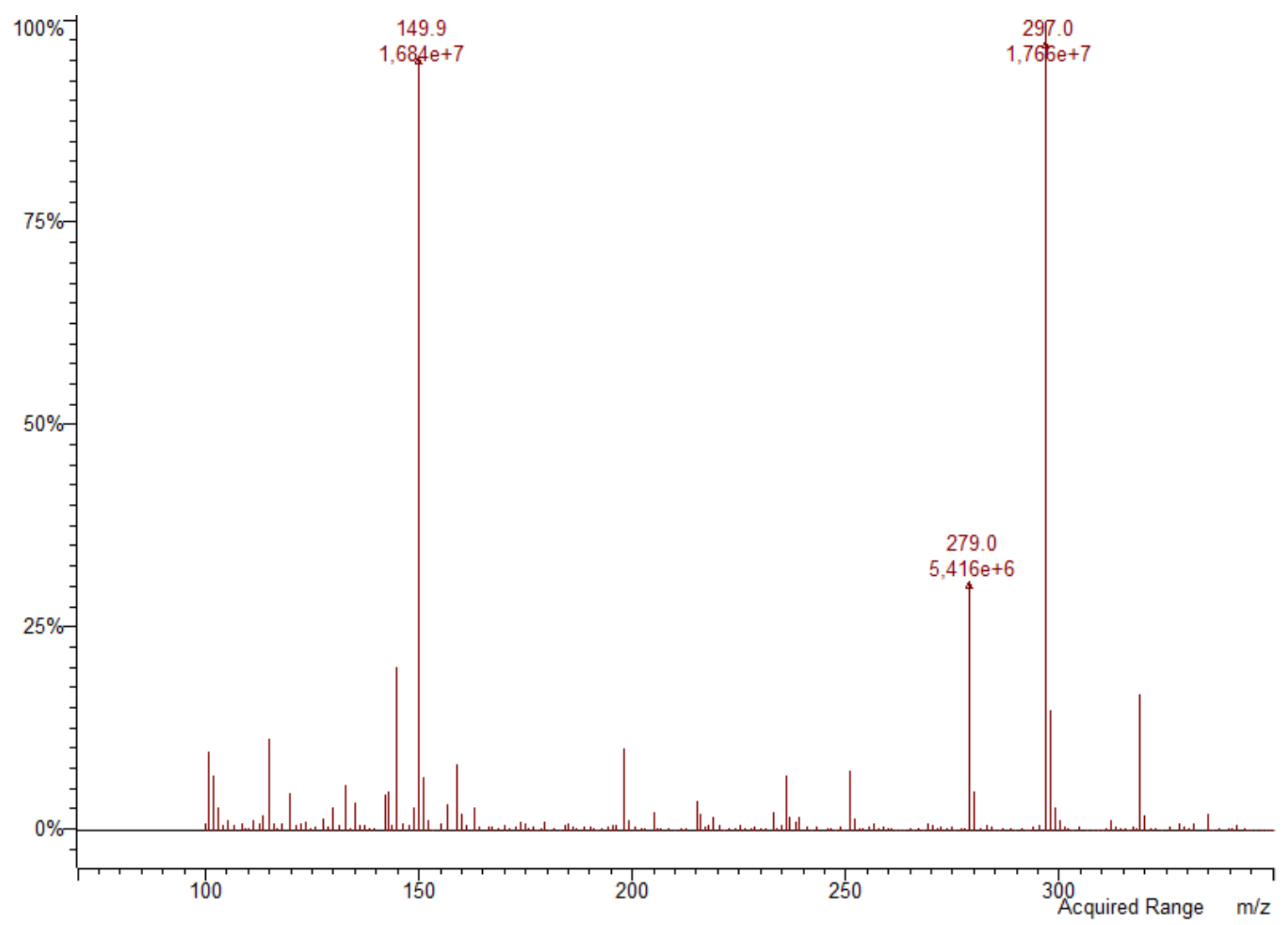

FIGURA 28. Espectro de massas $\left(\mathrm{ESI}^{+}\right)$do produto de degradação eluído a $45,8 \mathrm{~min}$.

Os dados da análise do íon $\mathrm{m} / \mathrm{z}=297,0$ por $\mathrm{MS}^{2}$, demonstrou a presença de fragmentos característicos do PABGA e ainda um acréscimo de 30 $\mathrm{m} / \mathrm{z}$ com relação ao mesmo (FIG. 29). Visto que no produto de degradação AHMP descoberto anteriormente houve uma oxidação, é possível que uma modificação similar poderia ter acontecido dando origem ao produto de degradação m/z 297,0. 
A análise dos fragmentos supõe uma substituição de dois hidrogênios por dois oxigênios. A posição ocupada pelo nitrogênio do grupo $p$-aminobenzóico no pABGA, poderia ser suscetível a esta dupla oxidação, formando desta forma um grupo nitro $\left(\mathrm{NO}_{2}\right)$. Esta substituição também explicaria uma menor polaridade deste composto de $\mathrm{m} / \mathrm{z} 297,0$, eluindo assim após o AF.

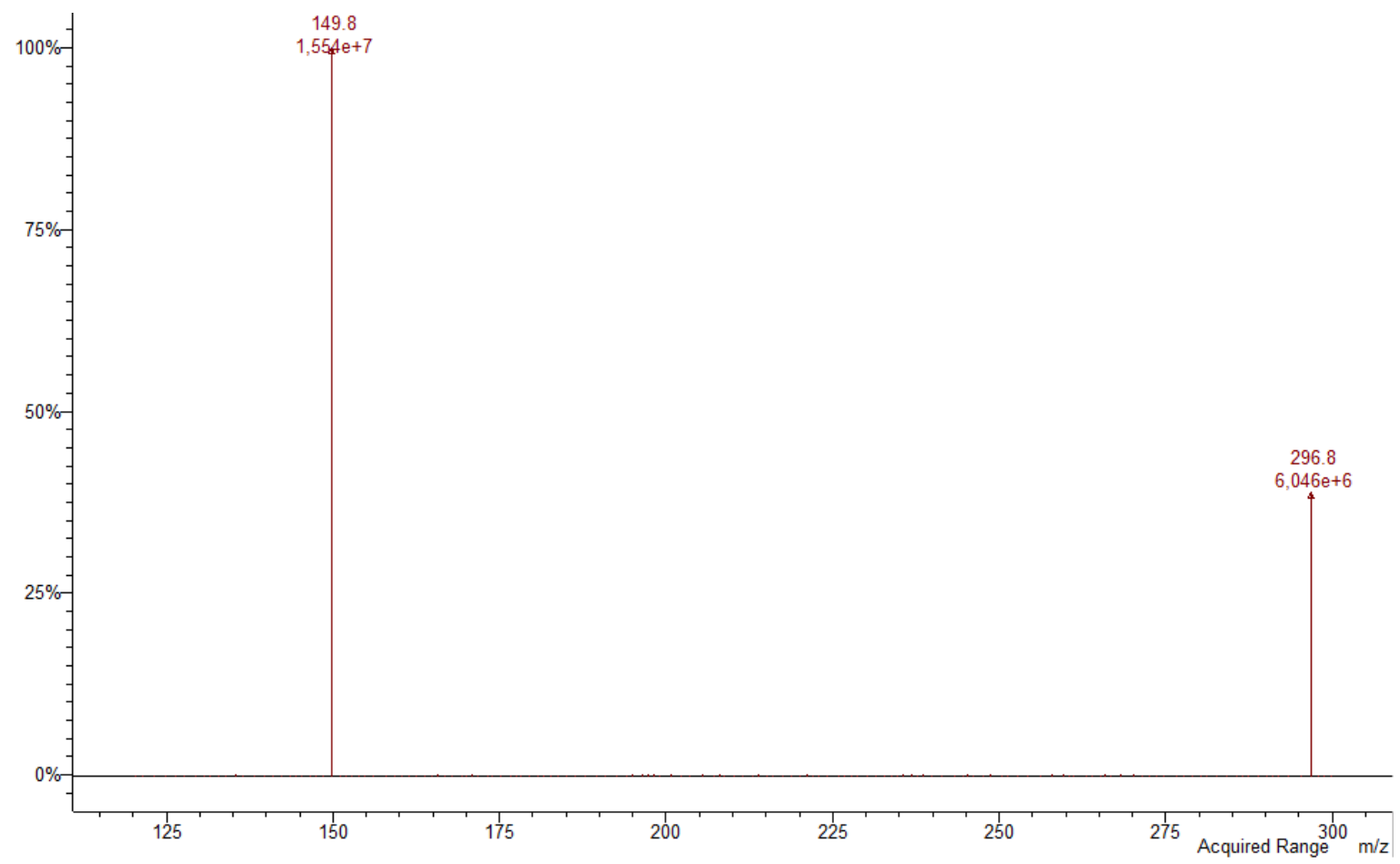

FIGURA 29. Espectro de massas em sequência $\left(\mathrm{MS}^{2}-\mathrm{ESI}^{+}\right)$do produto de degradação eluído com $\operatorname{tr}=45,8$ min.

A análise por HRMS confirmou o dado de m/z 297,07240. A fórmula molecular proposta $\mathrm{C}_{12} \mathrm{H}_{12} \mathrm{~N}_{2} \mathrm{O}_{7}$ confirmou as suposições sobre estrutura desta molécula obtidas do espectro $M^{2}$ e também confirmou a adição de dois oxigênios em relação ao pABGA (FIG. 30). Estes indícios permitiram a suposição de tratar-se do composto N-(4-nitrobenzoil)-L-ácido glutâmico (pNBGA). 


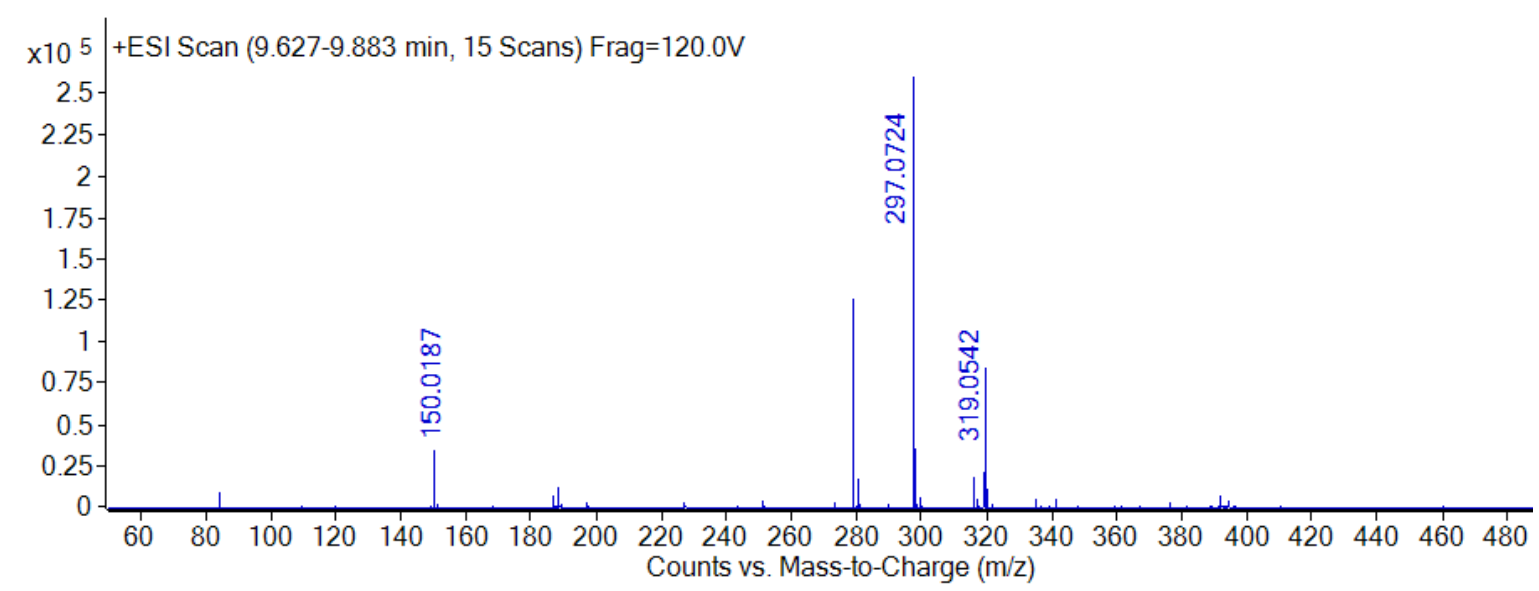

FIGURA 30. Espectro de massas HRMS $\left(\mathrm{ESI}^{+}\right)$do produto de degradação eluído a $45,8 \mathrm{~min}$.

Um padrão de pNBGA (CAS 6758-40-3) foi adquirido, apresentando os mesmos espectros MS e $M^{2}$ que o produto de degradação em estudo ( $\operatorname{tr}=45,8$ min). Igualmente apresentou mesmo tr (45,8 $\mathrm{min}$ ) e espectro UV do produto de degradação em questão (FIG. 31) (TAB. 8).

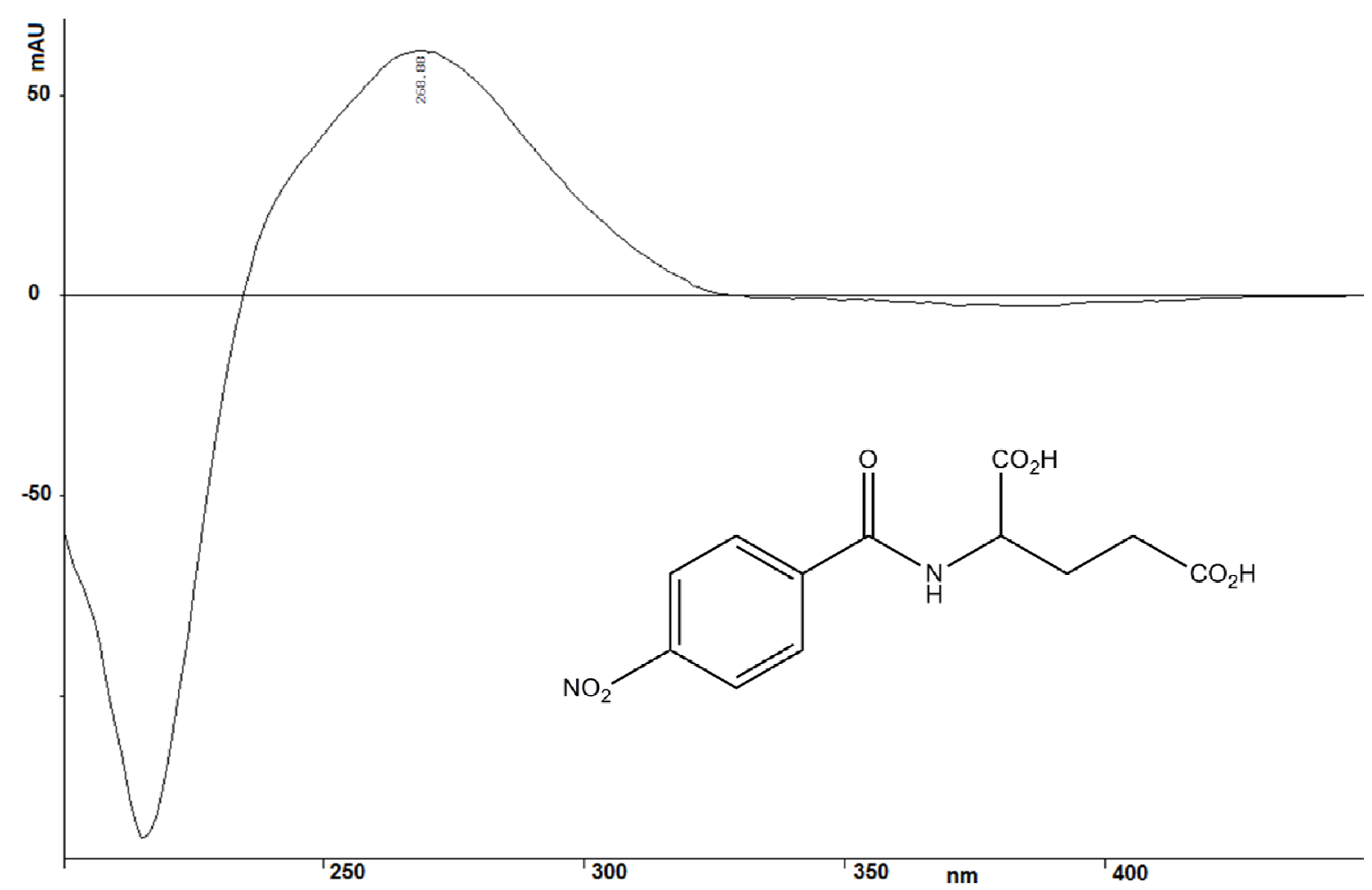

FIGURA 31. Estrutura química e espectro UV do pNBGA. 
Dois outros produtos de degradação do AF também foram encontrados em soluções de AF irradiadas com uma dose de radiação de 1 kGy, respectivamente nos $\operatorname{tr}=38,5$ e 40,5 min (FIG. 8B). Nenhuma informação sobre este produto (tr, espectro UV, MS, MS ${ }^{2}, H R M S$ ) foi coincidente com os fotoprodutos do AF conhecidos, o que nos levou a pensar em novos radioprodutos formados.

\section{Pico cromatográfico 5}

O produto de degradação com tr $=38,5$ (FIG. 8B, pico 5) apresentou uma $\mathrm{m} / \mathrm{z}$ de 458, ou seja, 16 daltons a mais que o AF. Esta diferença poderia ser provavelmente decorrente de um processo de oxidação do AF (FIG. 32). Este fato poderia explicar um tr menor que o encontrado para o $A F$, uma vez que esta molécula teria uma natureza mais polar.

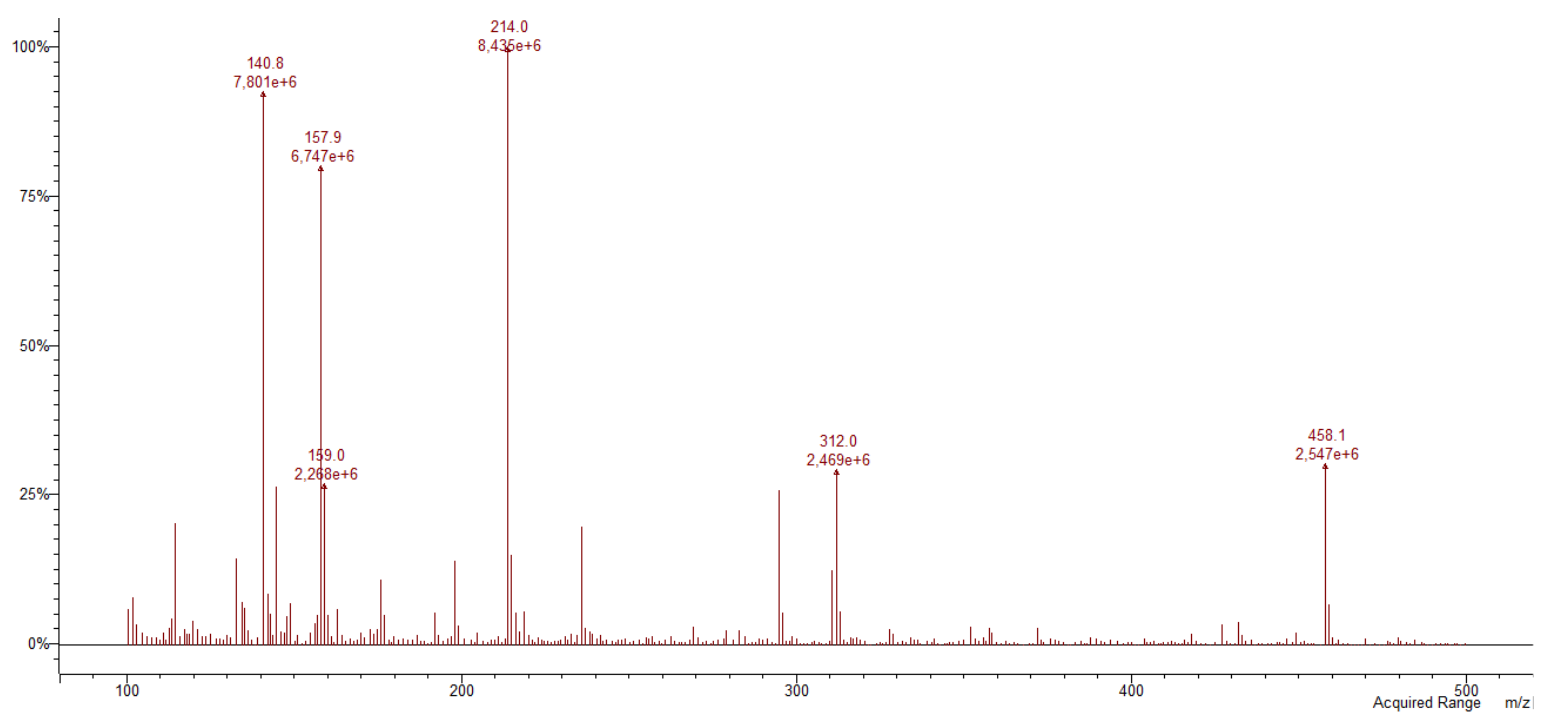

FIGURA 32. Espectro de massas (MS-ESI ${ }^{+}$) do produto de degradação eluído com $\operatorname{tr}=38,5 \mathrm{~min}$. 
Análises de HRMS indicaram uma fórmula bruta de $\mathrm{C}_{19} \mathrm{H}_{19} \mathrm{~N}_{7} \mathrm{O}_{7}$ (99,74\% de probabilidade), o que nos confirmou a suposição de uma oxidação do AF (FIG. 33).

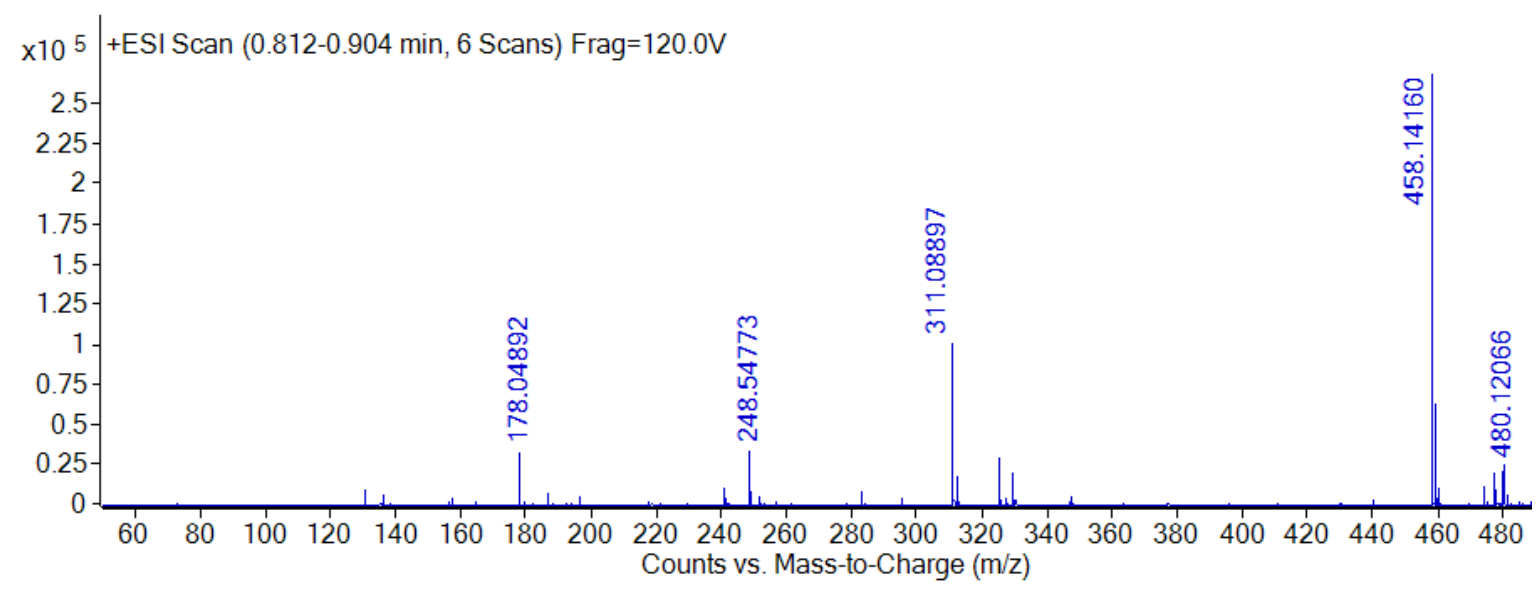

FIGURA 33. Espectro de massas HRMS $\left(\mathrm{ESI}^{+}\right)$do produto de degradação eluído a $38,5 \mathrm{~min}$.

Um investigação mais aprofundada foi realizada com o isolamento deste radioproduto por HPLC semi-preparativa para posterior confirmação da estrutura por ressonância magnética nuclear $(\mathrm{RMN})$ já que não há padrões comercialmente disponíveis. As soluções de AF irradiadas apresentavam baixa concentração $(0,1$ a $1 \mathrm{mg} / \mathrm{mL})$, impossibilitando o uso de uma coluna semipreparativa devido ao importante fator de diluição dos compostos no volume interno de uma coluna semi-preparativa. Logo, decidiu-se pelo uso da mesma coluna analítica fenil utilizada nas separações cromatográficas analíticas. A fim de realizar a coleta de uma maior quantidade possível dos picos cromatográficos de interesse, foram injetados volumes crescentes e a separação cromatográfica foi monitorada continuamente. Assim, foi constatado que um volume máximo de $150 \mu \mathrm{L}$ manteve uma boa resolução cromatográfica, com boa simetria dos picos, sem sobrecarregar a coluna cromatográfica (dados não mostrados). Entretanto, em função da baixa concentração deste radioproduto, a fração coletada foi insuficiente para a análise de RMN. 


\section{Pico cromatográfico 6}

O produto de degradação com tr = 40,5 min (FIG. 8B, pico 6) também apresentou uma $\mathrm{m} / \mathrm{z} 458$, novamente devido a um provável processo oxidativo que levou a inclusão de oxigênio nesta molécula (FIG. 34). Este fato também poderia explicar um tr menor que o encontrado para o $A F$, uma vez que esta molécula teria uma natureza mais polar. Podemos ainda supor que a oxidação sofrida por este composto, levou a formação de um produto de degradação de polaridade intermediária entre o pico cromatográfico de $\operatorname{tr}=38,5 \mathrm{~min}$ e o AF.

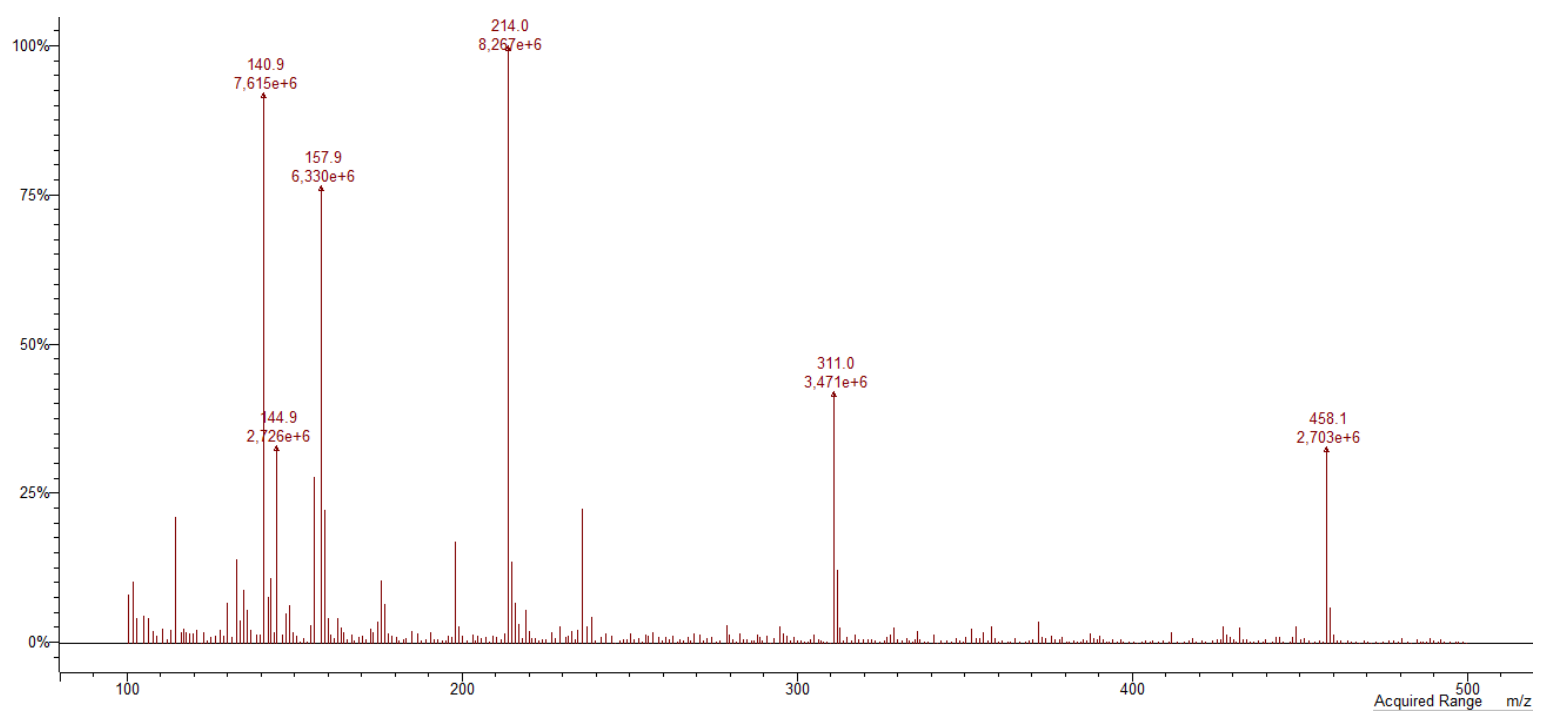

FIGURA 34. Espectro de massas (MS-ESI ${ }^{+}$) do produto de degradação eluído com $\operatorname{tr}=40,5 \mathrm{~min}$.

Análises de HRMS indicaram a mesma fórmula bruta do pico cromatográfico 5 , ou seja, $\mathrm{C}_{19} \mathrm{H}_{19} \mathrm{~N}_{7} \mathrm{O}_{7}$ (97,6\% de probabilidade). Este dado confirmou a suposição de uma oxidação do $\mathrm{AF}$ como exposto anteriormente (FIG. $35)$.

Assim como o exposto para o pico cromatográfico 5 , a baixa concentração obtida após a coleção da fração com o radioproduto 6 foi insuficiente para a análise de RMN e identificação deste produto. 


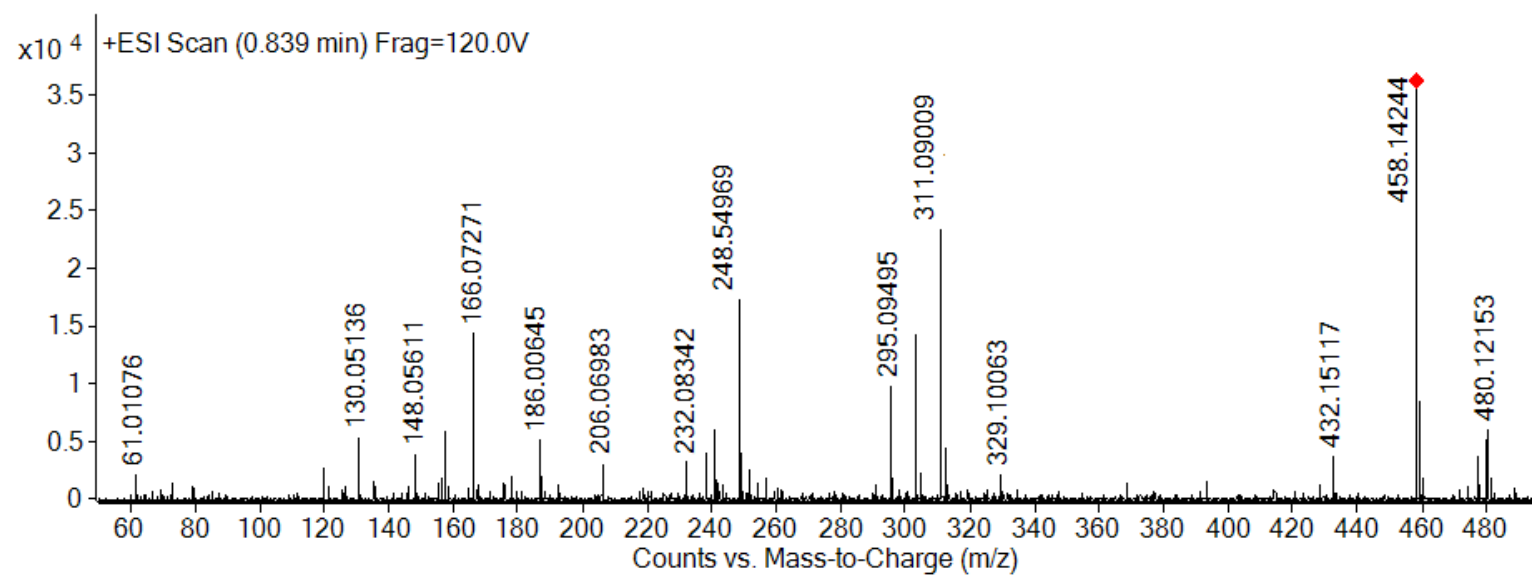

FIGURA 35. Espectro de massas HRMS $\left(\mathrm{ESI}^{+}\right)$do produto de degradação eluído a 40,5 min.

Muitos dos produtos de degradação do AF encontrados após 0 processamento por feixe de elétrons foram similares a produtos de degradação relatados na literatura decorrentes de outros tratamentos. Os dados de tr, massa molecular obtida por MS e HRMS e a fórmula molecular de cada produto de degradação formados após o tratamento por radiação estão resumidos na TAB. 8.

TABELA 8. Produtos de degradação do AF decorrentes do processamento por radiação e seus correspondentes tr, m/z (MS), m/z (HRMS) e fórmula molecular.

\begin{tabular}{ccccc}
\hline Composto & $\begin{array}{c}\text { Tempo de } \\
\text { retenção (min) }\end{array}$ & $\begin{array}{c}\text { MS } \\
{[\mathbf{M + H}]^{+}}\end{array}$ & $\begin{array}{c}\text { HRMS } \\
{[\mathbf{M + H}]^{+}}\end{array}$ & $\begin{array}{c}\text { Fórmula } \\
\text { molecular }\end{array}$ \\
\hline XA & 6,9 & 180,0 & 180,0518 & $\mathrm{C}_{6} \mathrm{H}_{5} \mathrm{~N}_{5} \mathrm{O}_{2}$ \\
AHMP & 8,7 & 194,0 & 194,0676 & $\mathrm{C}_{7} \mathrm{H}_{7} \mathrm{~N}_{5} \mathrm{O}_{2}$ \\
PCA & 13,2 & 208,0 & 208,0464 & $\mathrm{C}_{7} \mathrm{H}_{5} \mathrm{~N}_{5} \mathrm{O}_{3}$ \\
pABGA & 17,2 & 267,0 & 267,0992 & $\mathrm{C}_{12} \mathrm{H}_{14} \mathrm{~N}_{2} \mathrm{O}_{5}$ \\
PABA & 19,1 & 138,0 & 138,0549 & $\mathrm{C}_{7} \mathrm{H}_{7} \mathrm{NO}_{2}$ \\
Pico 5 & 38,5 & 458,0 & 458,14160 & $\mathrm{C}_{19} \mathrm{H}_{19} \mathrm{~N}_{7} \mathrm{O}_{7}$ \\
Pico 6 & 40,5 & 458,0 & 458,14244 & $\mathrm{C}_{19} \mathrm{H}_{19} \mathrm{~N}_{7} \mathrm{O}_{7}$ \\
pNBGA & 45,8 & 297,0 & 297,0724 & $\mathrm{C}_{12} \mathrm{H}_{12} \mathrm{~N}_{2} \mathrm{O}_{7}$ \\
\hline
\end{tabular}




\subsubsection{Processamento do AF em pó por aquecimento em estufa}

$\mathrm{O} A \mathrm{~F}$ mostrou uma degradação proporcional ao tempo de aquecimento em estufa a $200^{\circ} \mathrm{C}$. O aquecimento por um período de $10 \mathrm{~min}$ degradou o $\mathrm{AF}$ em menos de 10\%, por este razão não foi ilustrado o perfil cromatográfico (FIG. 36). Por outro lado, uma importante degradação do AF se deu com o aquecimento a partir de 45 min de tratamento, dando origem à formação de diversos produtos de degradação (FIG. 36).

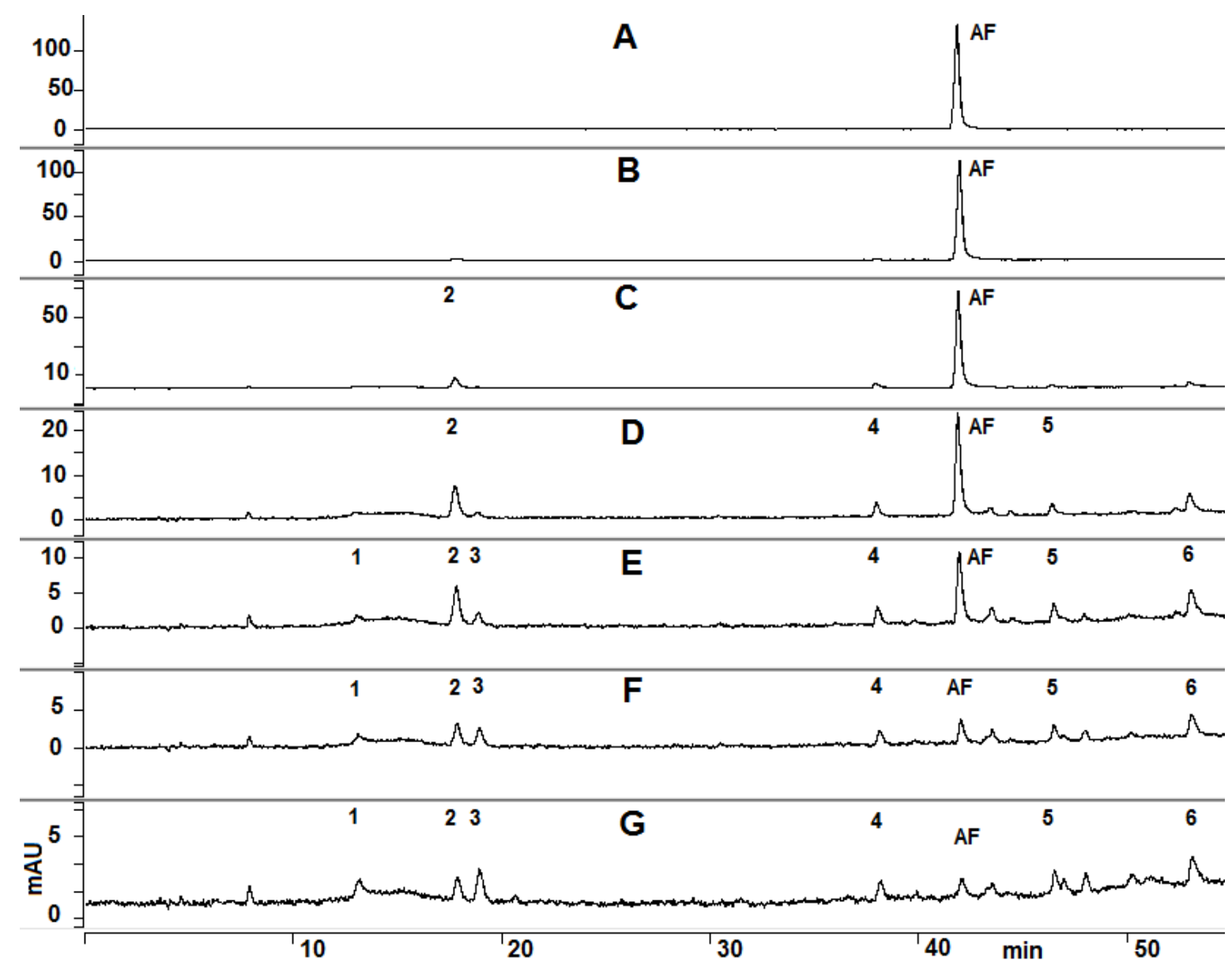

FIGURA 36. Perfis cromatográficos sobrepostos de soluções $(0,1 \mathrm{mg} / \mathrm{mL})$ preparadas com $A F$ em pó controle $(A)$ e $A F$ em pó aquecido em estufa durante $15 \min (B), 30 \min (C), 45 \min (D), 60 \min (E), 120 \min (F)$ e $180 \min (G)$. 
No perfil cromatográfico de uma solução aquosa de AF aquecida em estufa (FIG. 36), notou-se a presença de seis produtos de degradação majoritários com tempos de retenção (tr) 13,1; 17,7; 18,9; 38,1; 46,8 e 53,1 min, respectivamente os picos cromatográficos 1, 2, 3, 4, 5 e 6. Comparando-os com produtos de degradação já conhecidos, pode-se confirmar a identificação dos picos cromatográficos 1, 2, 3 e 5, com tr =13,1; 17,7; 18,9 e 46,8 min.

A termo-degradação do AF não veio acompanhada da formação de quantidades importantes de determinados produtos de degradação. Por outro lado, o tratamento térmico decompôs a molécula de AF em diversos fragmentos com baixa concentração.

\section{Pico cromatográfico 1}

O pico cromatográfico eluído a 13,1 min (FIG. 36, pico 1) mostrou os mesmos dados de tr, espectro UV e espectro MS do produto de degradação PCA (6-carboxipterina) (TAB. 9).

\section{Pico cromatográfico 2}

O tratamento térmico com uma duração de pelo menos $30 \mathrm{~min}$ acarretou uma formação importante do produto de degradação com $\operatorname{tr}=17,7$ min (FIG. 36, pico 2). Este composto apresentou tr, espectro UV e espectro MS similares aos encontrados para o pABGA, confirmando sua identificação (TAB. 9).

\section{Pico cromatográfico 3}

O tratamento térmico de longa duração, até $180 \mathrm{~min}$, levou a formação de um produto de degradação com tr =18,9 min (FIG. 36, pico 3). Este composto apresentou tr, espectro UV e espectro MS similares aos encontrados para o PABA, confirmando sua identificação (TAB. 9).

\section{Pico cromatográfico 5}

Diferentemente do processamento por radiação, uma solução preparada com o AF em pó submetido ao tratamento térmico analisada por espectrometria de massas evidenciou a presença do íon $[\mathrm{M}+\mathrm{H}]^{+}$de $\mathrm{m} / \mathrm{z} 313,0$, correspondente a massa molecular de 312,0. Este produto de degradação pareceu tratar-se do ácido pteróico (PA) $\left(\mathrm{C}_{14} \mathrm{H}_{12} \mathrm{~N}_{6} \mathrm{O}_{3}\right)$. $A$ análise por MS de uma 
solução padrão de PA confirmou este resultado, gerando igual espectro MS (FIG. 36 , pico 3). A formação deste produto de degradação veio da quebra da ligação amídica do AF entre a porção glutamato e a porção $p$-aminobenzóico.

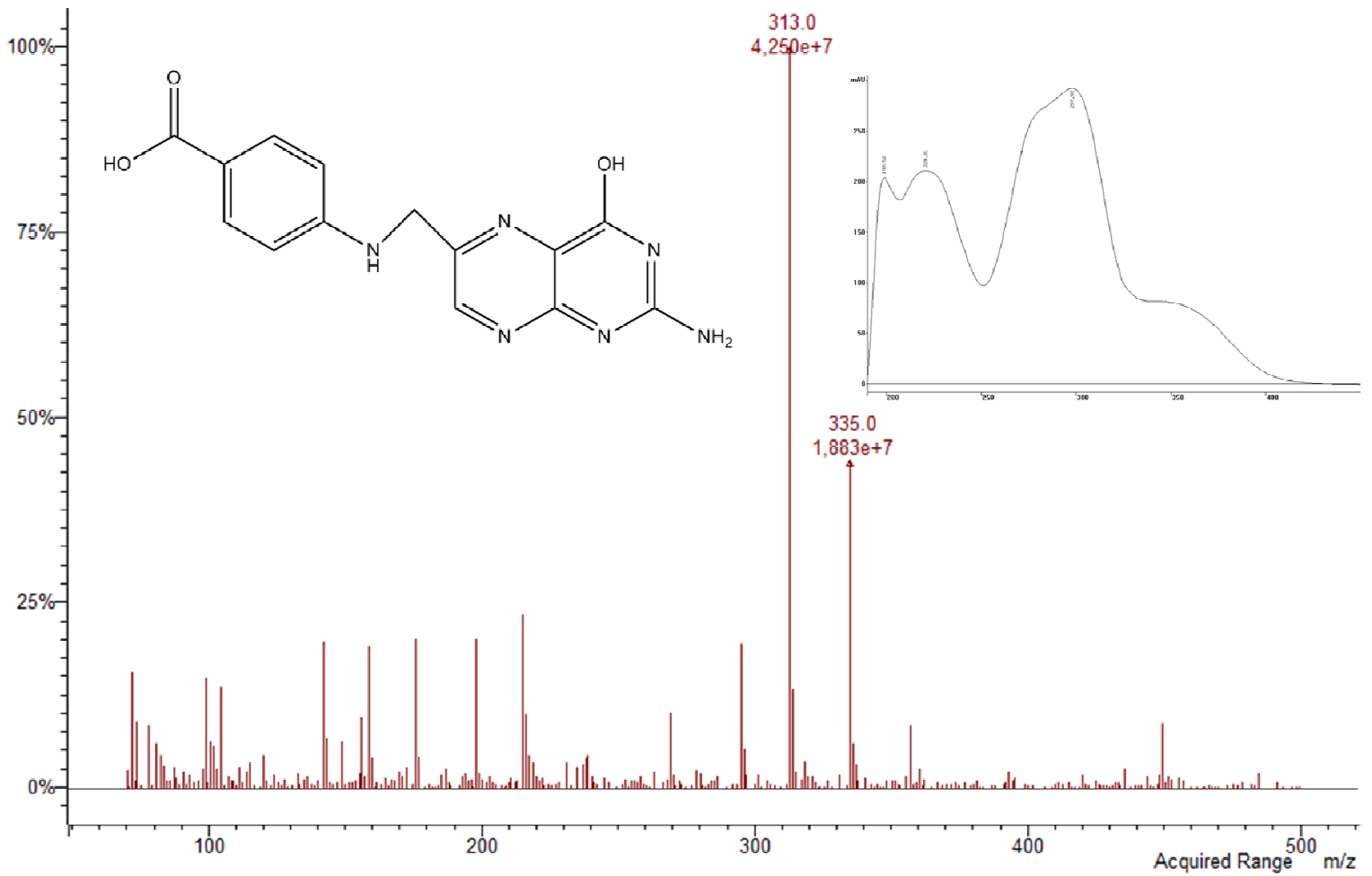

FIGURA 37. Estrutura química, espectro de absorção UV e espectro de massas $\left(E S I^{+}\right)$do PA $[\mathrm{M}+\mathrm{H}]^{+}$.

A injeção de uma solução padrão do PA com o método 2 resultou na eluição deste composto no mesmo tr $(46,8 \mathrm{~min})$ deste produto de degradação encontrado em amostras de AF em pó aquecidas (FIG. 37) (TAB. 9).

\section{Pico cromatográfico 4}

Além destes produtos de degradação já conhecidos, outros produtos foram observados nos cromatogramas (FIG. 35). As análises cromatográficas e espectrométricas do produto de degradação encontrado no $\mathrm{tr}=38,1 \mathrm{~min}$ (FIG. 36, pico 4) não forneceram informações suficientes para a atribuição de uma possível estrutura química. 


\section{Pico cromatográfico 6}

O tratamento térmico também promoveu a formação de outro novo produto de degradação no $\operatorname{tr}=53,1 \mathrm{~min}$ (FIG. 36, pico 6). Assim como para o pico cromatográfico 4 , os dados obtidos não foram suficientes para sua identificação.

Em um estudo sobre a termo-estabilidade do AF, Vora et al. (2002) propuseram que inicialmente a fração glutamato do $A F$ se rompe deixando a amida como componente principal. Em seguida a pterina e o PABA se decompõe em um mecanismo de overlapping. Sugeriram também, que a $195^{\circ} \mathrm{C}$ não é possível discernir grupos presentes no $A F$, indicando uma completa decomposição do $\mathrm{AF}$ nesta temperatura. Uma vez que o $\mathrm{AF}$ não tem ponto de fusão definido, o AF escurece a $250^{\circ} \mathrm{C}$ seguido de um a importante carbonização (Ball, 2006). Estes resultados poderiam explicar a razão pela qual neste estudo percebeu-se uma importante degradação do AF, com a formação de outros produtos de degradação (picos 4 e 6) que não apresentaram informações que pudessem levar à sua identificação.

Os principais produtos de degradação discerníveis decorrentes do processamento por aquecimento em estufa estão resumidos da TAB. 9.

TABELA 9. Produtos de degradação decorrentes do tratamento térmico do AF e seus correspondentes tr, $\mathrm{m} / \mathrm{z}$ (MS) e fórmula molecular.

\begin{tabular}{cccc}
\hline Composto & $\begin{array}{c}\text { Tempo de } \\
\text { retenção (min) }\end{array}$ & $\begin{array}{c}\text { MS } \\
{[\mathbf{M + H}]^{+}}\end{array}$ & $\begin{array}{c}\text { Fórmula } \\
\text { molecular }\end{array}$ \\
\hline PCA & 13,1 & 208,0 & $\mathrm{C}_{7} \mathrm{H}_{5} \mathrm{~N}_{5} \mathrm{O}_{3}$ \\
PABGA & 17,7 & 267,0 & $\mathrm{C}_{12} \mathrm{H}_{14} \mathrm{~N}_{2} \mathrm{O}_{5}$ \\
PABA & 18,9 & 138,0 & $\mathrm{C}_{7} \mathrm{H}_{7} \mathrm{NO}_{2}$ \\
Pico 4 & 38,1 & --- & --- \\
PA & 46,8 & 313,0 & $\mathrm{C}_{14} \mathrm{H}_{12} \mathrm{~N}_{6} \mathrm{O}_{3}$ \\
Pico 6 & 53,1 & --- & --- \\
\hline
\end{tabular}




\subsubsection{Processamento por micro-ondas}

O processamento por micro-ondas teve um importante efeito nas soluções de AF. Como anteriormente exposto, este tratamento promoveu uma importante degradação do AF (FIG. 38).

O tratamento em forno micro-ondas por 5 min mostrou uma degradação do $A F$ inferior a $2 \%$, por esta razão não foi ilustrado o perfil cromatográfico. Nas soluções de AF submetidas ao tratamento em forno microondas por 10 min ainda foi observado o pico correspondente ao AF no cromatograma (FIG. 38). Entretanto, a partir de $15 \mathrm{~min}$ ocorreu 0 desaparecimento completo do AF nas soluções estudadas.

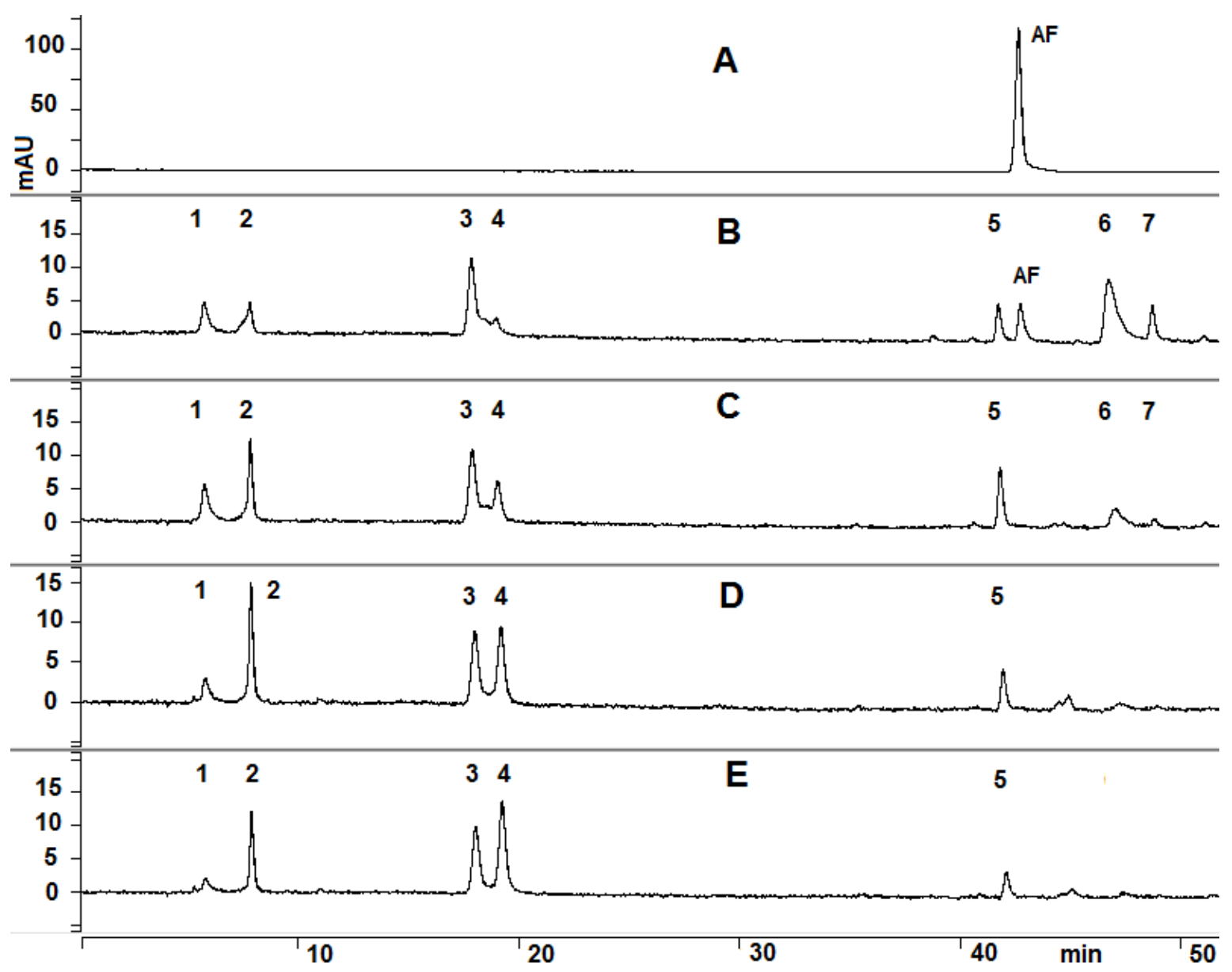

FIGURA 38. Perfis cromatográficos sobrepostos de soluções $(0,1 \mathrm{mg} / \mathrm{mL})$ controle (A) e processadas em micro-ondas durante $10 \mathrm{~min}(\mathrm{~B}), 15 \mathrm{~min}$ (C), $20 \mathrm{~min}$ (D) e $25 \min (E)$. 
No perfil cromatográfico de uma solução aquosa de AF aquecida em forno micro-ondas (FIG. 38), notou-se que a presença do AF ( $\operatorname{tr}=42,7 \mathrm{~min}$ ) apenas no processamento por micro-ondas até um tempo de $10 \mathrm{~min}$. Percebe-se ainda a presença de sete produtos de degradação majoritários com tempos de retenção (tr) 5,7; 7,9; 17,8; 18,9; 41,7;46,7 e 48,7 min, respectivamente os picos cromatográficos $1,2,3,4,5,6$ e 7 .

Dois dos produtos de degradação encontrados nas soluções de AF processadas por micro-ondas foram identificados quando comparados à padrões de produtos de degradação conhecidos do AF (pico 3 e 4) (FIG. 38). As análises cromatográficas e espectrométricas dos outros produtos de degradação não forneceram informações para uma identificação dos demais compostos (picos 1, $2,5,6,7)$.

\section{Pico cromatográfico 3}

O produto de degradação eluído a 17,8 min representado pelo pico cromatográfico 2, apresentou tr, espectro UV e espectro MS coerentes com o produtos de degradação conhecido pABGA (FIG. 38, pico 2).

\section{Pico cromatográfico 4}

Os dados de tr, espectro UV e espectro MS do pico cromatográfico com $\operatorname{tr}=18,9$ min foram similares ao produto de degradação PABA (ácido p-aminobenzóico) (FIG. 38, pico 3).

\section{Pico cromatográfico 1}

O processamento por micro-ondas de uma solução de AF, promoveu a formação de outros produtos de degradação como observado nos cromatogramas LC/UV/MS (FIG. 38). O produto de degradação com tr = 5,7 min (FIG. 38, pico 1) não apresentou dados cromatográficos e/ou espectrométricos comparáveis a nenhum produto de degradação do AF conhecido.

A análise por LC/MS indicou a presença dos íons $[\mathrm{M}+\mathrm{H}]^{+} \operatorname{com} \mathrm{m} / \mathrm{z}=$ 119,9 e 167,9 . 


\section{Pico cromatográfico 2}

O processamento por radiação promoveu a formação de outro produto de degradação no $\operatorname{tr}=7,9$ min (FIG. 38, pico 2). Este novo composto não coincidiu com nenhum produto de degradação conhecido. A análise por LC/MS indicou a presença do íon com $\mathrm{m} / \mathrm{z}=119,9[\mathrm{M}+\mathrm{H}]^{+}$.

\section{Pico cromatográfico 5}

Um novo produto de degradação foi encontrado no tr $=41,7 \mathrm{~min}$ (FIG. 38, pico 5). O espectro MS deste produto evidenciou a presença do íon de $\mathrm{m} / \mathrm{z}$ $288,0[\mathrm{M}+\mathrm{H}]^{+}$.

\section{Pico cromatográfico 6}

Uma solução de AF aquecida em forno micro-ondas por até $10 \mathrm{~min}$ promoveu a formação de um produto de degradação com tr $=46,7$ min (FIG. 38, pico 6). Os dados espectrométricos deste composto indicaram a presença dos íons com m/z 119,9; 270,9 e 418,1 [M+H] $]^{+}$.

\section{Pico cromatográfico 7}

De maneira similar, o processamento em forno micro-ondas de uma solução de AF por até $10 \mathrm{~min}$ promoveu o surgimento de um produto de degradação no $\operatorname{tr}=48,7 \mathrm{~min}$ (FIG. 38, pico 7). A análise por espectrometria de massas indicou a presença dos íons com $\mathrm{m} / \mathrm{z}$ 150,9; 270,0 e 418,2 [M+H] $]^{+}$.

Os produtos de degradação decorrentes do processamento por microondas estão resumidos da TAB. 10. 
TABELA 10. Produtos de degradação decorrentes do processamento por microondas do AF e seus correspondentes tr, m/z (MS) e fórmula molecular.

\begin{tabular}{cccc}
\hline Composto & $\begin{array}{c}\text { Tempo de } \\
\text { retenção (min) }\end{array}$ & $\begin{array}{c}\text { MS } \\
{[\mathbf{M + H}]^{+}}\end{array}$ & $\begin{array}{c}\text { Fórmula } \\
\text { molecular }\end{array}$ \\
\hline Pico 1 & 5,7 & 167,9 & --- \\
Pico 2 & 7,9 & 119,9 & --- \\
pABGA & 17,8 & 267,0 & $\mathrm{C}_{12} \mathrm{H}_{14} \mathrm{~N}_{2} \mathrm{O}_{5}$ \\
PABA & 18,9 & 138,0 & $\mathrm{C}_{7} \mathrm{H}_{7} \mathrm{NO}_{2}$ \\
Pico 5 & 41,7 & 288,0 & --- \\
Pico 6 & 46,7 & 418,1 & --- \\
Pico 7 & 48,7 & 418,2 & -- \\
\hline
\end{tabular}

\subsubsection{Comparação entre os Diferentes Processamentos}

Os diferentes tratamentos ao qual o AF foi submetido ocasionaram uma intensa degradação do mesmo e a formação de diversos produtos de degradação.

A grande maioria dos produtos de degradação encontrados neste estudo foram similares à produtos de degradação já conhecidos. Tannenbaum et al. (1985) mostraram que uma hidrólise alcalina sob condições aeróbicas promoveu uma clivagem oxidativa da molécula de AF originando o pABGA e o PCA.

Os resultados deste estudo vão ao encontro com muitos outros que analizaram a fotólise do AF. O primeiro estudo publicado por Lowry et al. (1949), propôs que como resultado do processo de fotólise, o AF se degrada em pABGA e PCA. Entretanto não precisou o tipo de luz aplicada neste estudo. Em um outro estudo, Saxby et al. (1983) avaliaram a estabilidade à luz fluorescente do AF em solução aquosa ( $\mathrm{pH} 5,0)$ e na cerveja ( $\mathrm{pH} 5,0)$, com ou sem acréscimo de dióxido de enxofre $\left(\mathrm{SO}_{2}\right)$, um agente preservante e antioxidante. Estes autores verificaram o efeito fotoprotetor do $\mathrm{SO}_{2}$ e identificaram a formação de três 
compostos decorrentes da degradação do AF, o PCA, o pABGA e provavelmente a 6-metilpterina. É importante salientar que a luz emitida por lâmpadas fluorescentes é menos efetiva na fotólise que a luz solar, principalmente devido ao fator UV da exposição solar.

Posteriormente, diversos outros estudos foram realizados sobre a fotólise do AF sob luz ultra-violeta (UV). Akhtar et al. (1997, 1999, 2003) estudaram os efeitos de diferentes pHs na fotodegradação do AF por UV. Encontraram como produtos de degradação majoritários PABA, PCA, pABGA e PA.

Ainda com relação à fotólise, diversos autores propuseram que em presença de oxigênio, o AF em solução aquosa é inicialmente clivado fotoquimicamente na ligação $\mathrm{C}_{9}-\mathrm{N}_{10}$ formando pABGA e 6-formilpterina (FPT) $\left(\mathrm{C}_{7} \mathrm{H}_{5} \mathrm{~N}_{5} \mathrm{O}_{2}\right.$, MW: 191) (Thomas et al., 2000; Off et al., 2005; Vorobey et al., 2006; Dántola et al., 2010). Com o avanço do processo de fotólise, ocorre a fotooxidação do grupo 6-formil do FPT e formação do 6-carboxipterina (PCA). Contrariamente ao presente estudo, depois do tratamento com feixe de elétrons nenhum traço do FPT foi detectado, provavelmente devido a velocidade do processo de degradação promovida pela irradiação com feixe de elétrons e à alta energia envolvida que aceleraram a formação do PCA.

Outros autores (Akhtar et al., 1997; Scurachio et al., 2011) estudaram o efeito da foto-oxidação dos folatos sensibilizados pela riboflavina, encontrando também o PCA e o pABGA como produtos de degradação.

O tratamento com feixe de elétrons promoveu uma degradação do AF em compostos de degradação similares à fotólise com luz UV, entretanto novos produtos de degradação foram encontrados. Isto é esperado uma vez que o tratamento com feixe de elétrons é um tratamento em profundidade, mais energético e com taxas de dose maiores que o tratamento UV.

Poucos estudos tentaram elucidar o processo degradativo do AF depois do processamento por radiação ionizante; estes preconizam também 0 surgimento do PCA e do pABGA como produtos de degradação. Nakken \& Pihl (1966) estudaram a degradação induzida por raios $X$ de soluções de AF, PABA, pABGA e $\mathrm{N}$-(p-aminobenzoil)glicina em tampão fosfato ( $\mathrm{pH} 7,4)$. Estes autores propuseram também que um ponto de ataque suscetível na molécula de AF pelos 
radicais induzidos pela radiação seria a ligação $\mathrm{C}_{9}-\mathrm{N}_{10}$, resultando em pABGA e PCA. Igualmente 3-OH-pABGA e o-amino-fenóis foram encontrados.

Em outro estudo, Kesavan et al. (2003) avaliaram os efeitos da radiação gama na degradação de folatos em ratos irradiados de corpo inteiro com doses de 2, 5, 7 Gy. Eles também observaram que a irradiação fragmentou a molécula de AF em pterina e pABGA devido ao dano oxidativo.

Independentemente do tratamento ao qual o AF seja submetido, é sabido que, as frações pteridina, $p$-aminobenzóico e glutamato, separadamente, não têm atividade vitamínica (Akhtar et al., 1999; Guilland et al., 2009; Off et al., 2005; USA, 1975). Assim, o decréscimo do conteúdo de AF decorrente do processamento de alimentos ocasiona um decréscimo da atividade do folato devido à formação de possíveis produtos de degradação inativos.

É sabido que o AF deva estar íntegro para que tenha sua atividade biológica específica. Os dados disponíveis na literatura não apontam um potencial tóxico dos produtos de degradação PABA, pABGA, PA e PCA do AF. Também não foram encontrados dados na literatura sobre uma possível toxicidade dos novos produtos de degradação XA, AHMP e pNBGA encontrados neste estudo.

\subsection{Cinética de Degradação do AF}

\section{Processamento por Radiação}

O processamento por radiação de uma solução aquosa de AF gerou diversos produtos de degradação. Entretanto, as concentrações individuais dos produtos de degradação encontrados não atingiu 10\% da concentração inicial de AF na solução não irradiada (100 $\mu \mathrm{g} / \mathrm{mL})$ (FIG. 39).

Compostos como o pABGA e o AHMP foram gerados em quantidades muito pequenas, não alcançando uma concentração de $2,0 \mu \mathrm{g} / \mathrm{mL}(2 \%$ da concentração inicial de AF) (FIG. 39).

Para a XA foi encontrado um resultado similar, alcançando apenas 3,70 $\mu \mathrm{g} / \mathrm{mL}$ com altas doses de radiação ao redor de 5 kGy. Por outro lado, o pNBGA mostrou um crescimento acentuado até uma dose de radiação de 1 kGy, atingindo assim uma concentração final de pouco menos de 7,0 $\mu \mathrm{g} / \mathrm{mL}$ (FIG. 39). 


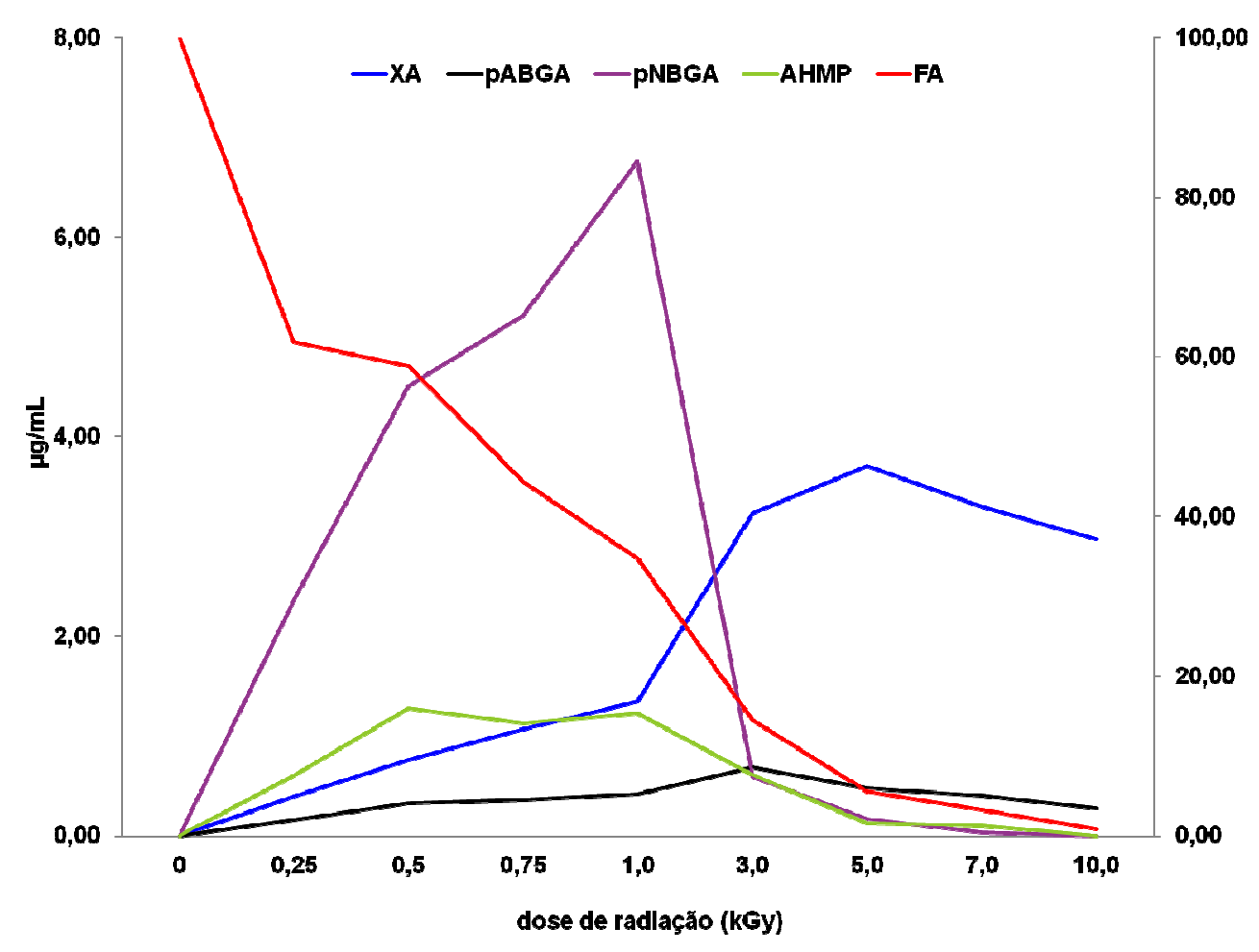

FIGURA 39. Cinética de degradação do AF por irradiação e formação de produtos de degradação (concentração de $\mathrm{AF}$ representado na escala à direita).

Tendo em vista estas curvas de cinética de degradação e formação de novos compostos, pode-se propor uma série de hipóteses para o processo degradativo do AF.

A presença do PABGA e PCA nas soluções de AF irradiadas propôs a clivagem da ligação $C_{9}-N_{10}$ da molécula de $A F$. Entretanto, as quantidades de PCA encontradas nas soluções de AF irradiadas são mínimas. A formação de AHMP e XA propôs a ocorrência de dois possíveis mecanismos. No primeiro mecanismo, ocorreu uma transformação do PCA com formação da XA. No segundo mecanismo, ocorreu uma redução do PCA e formação do AHMP (Fig. 40).

O pABGA também foi detectado em pequenas quantidades, o que sugeriu um mecanismo de reação similar. Isto vai ao encontro com quantidades 
crescentes de pNBGA nas soluções irradiadas, levando a crer que o pABGA sofreu uma oxidação dando origem ao pNBGA (Fig. 40).

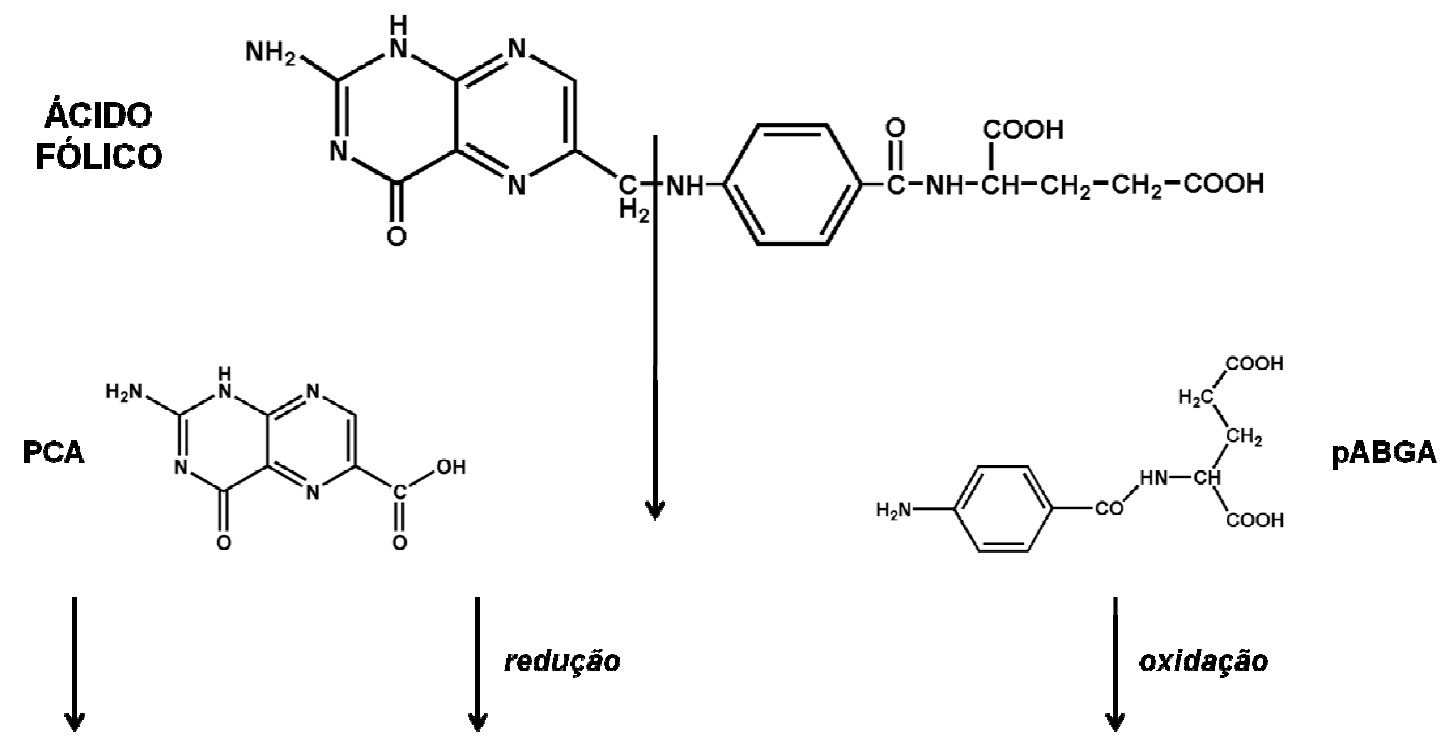<smiles>Nc1nc(=O)c2[nH]c(=O)cnc2[nH]1</smiles>

XA

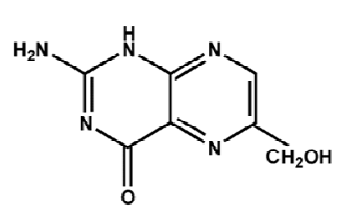

AHMP

FIGURA 40. Esquema proposto para a radiodegradação do AF.

\section{Processamento por Aquecimento em Estufa}

O aquecimento em estufa de amostras de AF em pó a $200^{\circ} \mathrm{C}$ acarretou a formação de produtos de degradação diretamente proporcional ao tempo de aquecimento. Um longo período de exposição (180 min) ocasionou a decomposição quase completa do AF.

Assim como descrito para o tratamento com radiação ionizante, as concentrações individuais dos produtos de degradação atingiram valores baixos, menos de $5 \%$ da concentração inicial de AF controle (100 $\mu \mathrm{g} / \mathrm{mL})$ (FIG. 41). 


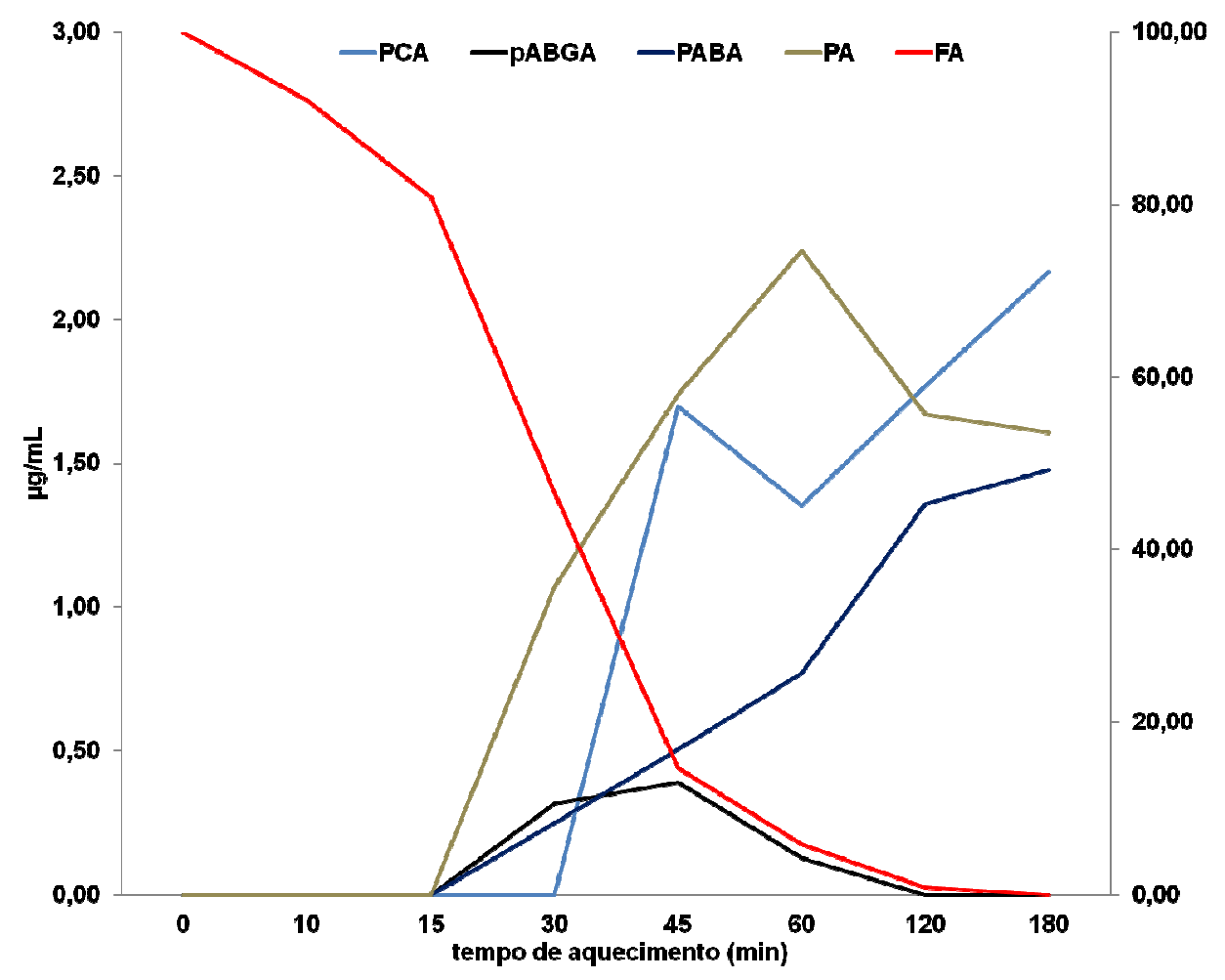

FIGURA 41. Cinética de degradação do AF por aquecimento em estufa e formação de produtos de degradação (concentração de AF representado na escala à direita).

Diferentemente do processamento por radiação, as amostras de AF foram submetidas ao processamento por calor na forma de pó. Assim, este processo envolveu apenas um fenômeno físico de degradação da molécula do AF.

Um aquecimento do AF em pó superior a 15 minutos promoveu a clivagem da molécula de AF em diferentes posições, como exposto no possível esquema de termodegradação do AF (FIG. 42): uma ruptura da ligação C9-N10, originando o PCA e o pABGA; a perda da fração glutâmica, originando o PA; a perda simultânea da fração glutâmica e da pterina, restando o PABA.

A presença de água no processamento por radiação favoreceu reações oxidativas, diferentemente do processamento por aquecimento em estufa. 
A ausência de reações oxidativas decorrente da termodegradação do AF não promoveu a oxidação do PCA com formação do AHMP e XA. O processo oxidativo do PABGA também não ocorreu, logo não houve consequentemente a formação de pNBGA. No caso do PABGA, ao que tudo indica, a partir de $45 \mathrm{~min}$ de aquecimento ocorreu uma clivagem da ligação amídica entre o PABA e a fração glutamato, contribuindo assim para o aumento da concentração de PABA.

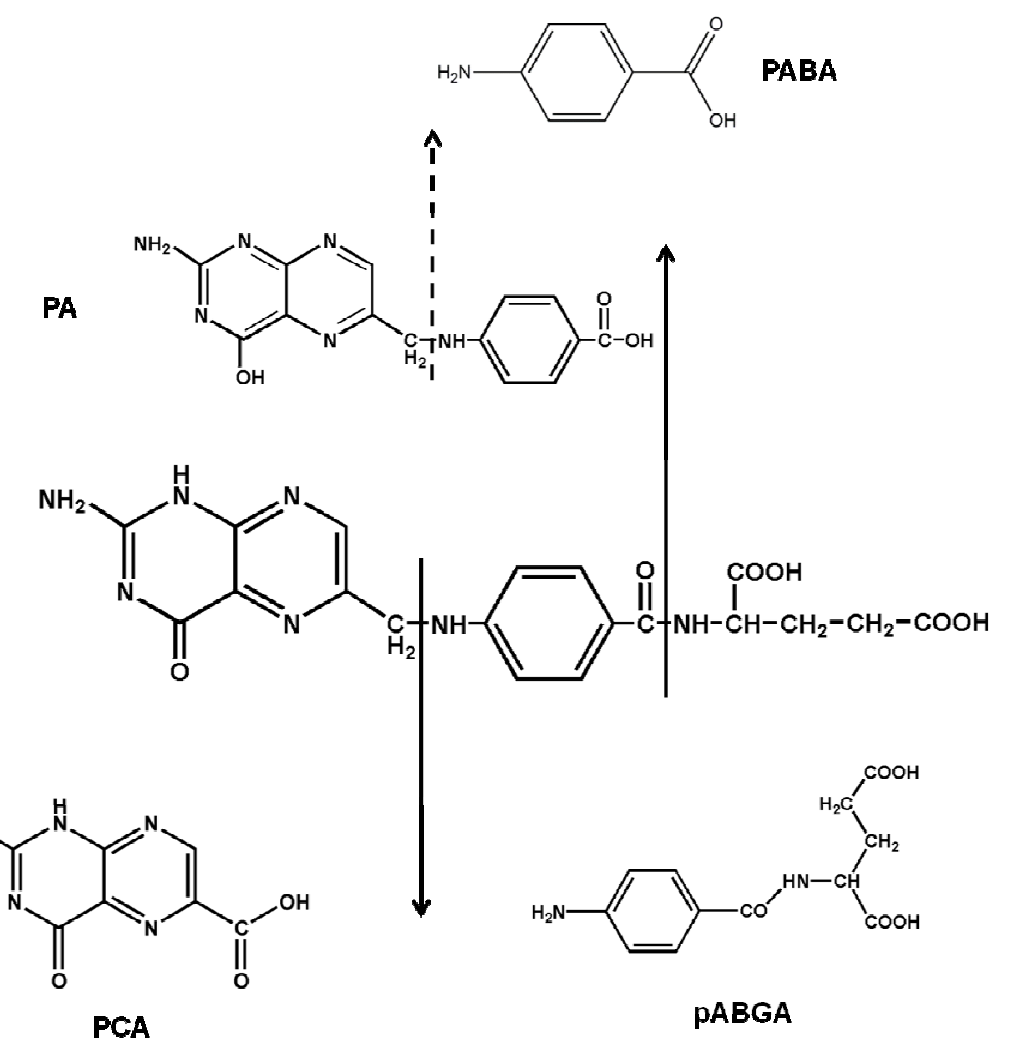

FIGURA 42. Esquema proposto para a termodegradação do AF. 


\section{Processamento em Forno Micro-ondas}

$O$ aquecimento de soluções aquosas de AF em forno micro-ondas promoveu o aparecimento do pABGA e PABA como produtos de degradação majoritários. Um tempo de aquecimento superior a 10 minutos promoveu uma expressiva degradação do $A F$, gerando um aumento da concentração de pABGA e PABA. Decorridos 25 minutos de aquecimento a concentração de PABA alcançou 9,18 $\mu \mathrm{g} / \mathrm{mL}$ (FIG. 43).

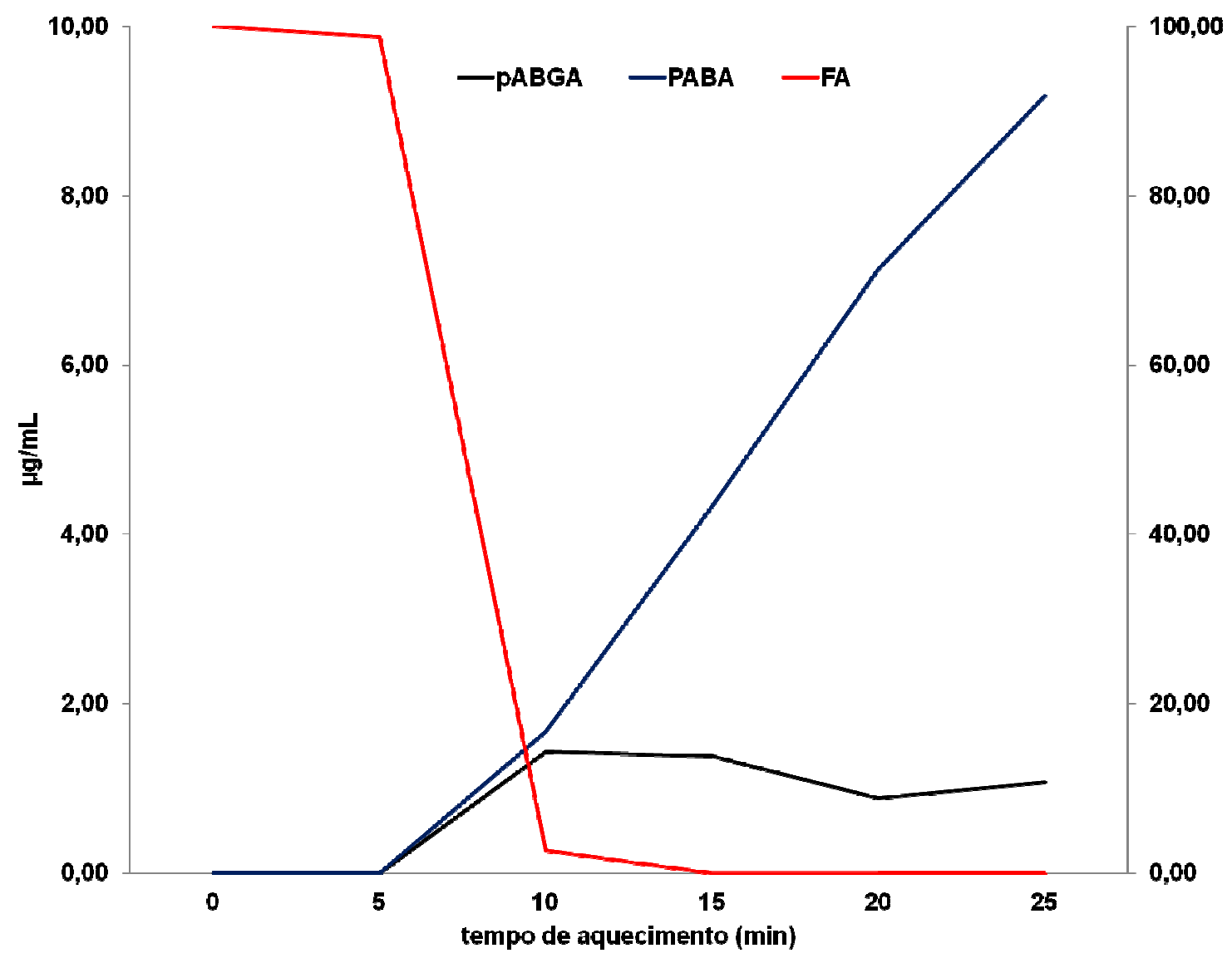

FIGURA 43. Cinética de degradação do AF por aquecimento em forno microondas e formação de produtos de degradação (concentração de AF representado na escala à direita).

O processamento por micro-ondas promoveu a ruptura da ligação C9-N10 da molécula de AF, originando o pABGA. Ainda que as amostras de AF tenham sido submetidas ao processamento por micro-ondas em solução, diferentemente 
da irradiação não ocorreu uma reação oxidativa do pABGA e formação de pNBGA. No caso da irradiação, o efeito indireto dos produtos radiolíticos da água poderia ter promovido este mecanismo (FIG. 44).

Sabendo que houve a clivagem entre C9-N10 era esperado encontrar o PCA como produto de degradação também nas soluções de AF aquecidas em micro-ondas. Provavelmente ocorreu uma degradação desse composto e consequente formação de outros produtos de degradação.

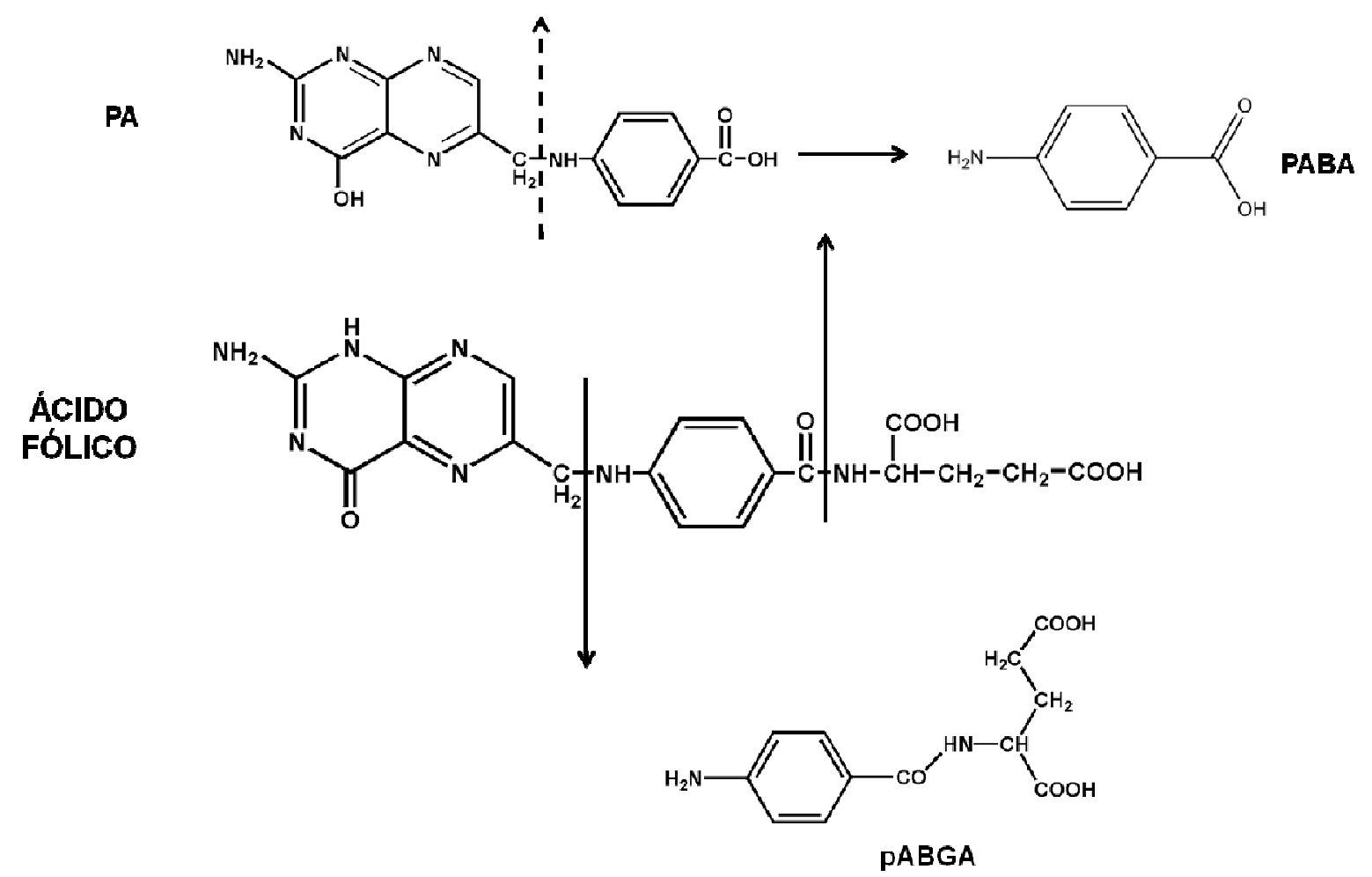

FIGURA 44. Esquema proposto para a degradação do AF por micro-ondas. 


\section{CONCLUSÕES}

$\mathrm{O}$ processamento por radiação ionizante do $\mathrm{AF}$ em suspensão não ocasionou um processo degradativo na molécula do AF.

O tratamento por irradiação, aquecimento em estufa e com forno microondas levou a uma importante degradação do AF em solução.

Foram encontrados diversos produtos de degradação decorrentes dos três processamentos aplicados, a saber:

- foram encontrados os produtos de degradação PCA, PABA, pABGA após a irradiação do AF;

- foram identificados três novos produtos de degradação decorrentes do processamento por radiação ionizante: XA, AHMP e pNBGA;

- foram encontrados os produtos de degradação PCA, PABA, pABGA e PA após o aquecimento em estufa a 200 C;

- foram encontrados os produtos de degradação PABA e pABGA após o aquecimento com forno micro-ondas;

- os novos produtos de degradação identificados não têm atividade vitamínica uma vez que esta atividade biológica é encontrada apenas no AF íntegro;

- a degradação do AF decorrente dos processamentos aplicados ressalta a necessidade de constante avaliação dos níveis de fortificação de alimentos para que quantidade suplementada da vitamina seja adequada. 


\section{CAPÍTULO 3: DESENVOLVIMENTO DE UM MÉTOdO DE EXTRAÇÃO POR SOLVENTE PRESSURIZADO DE ÁCIDO FÓLICO EM FARINHAS DE TRIGO FORTIFICADAS}

Atualmente, devido ao número crescente de alimentos fortificados no mercado e por causa da sua importância na saúde da população em geral, métodos confiáveis e rápidos são necessários para a extração e quantificação do AF em cereais fortificados.

O método microbiológico (MM) é o método padrão para a quantificação de folatos e AF. Entretanto, além de levar muito tempo e requerer condições de trabalho estéreis, é pouco específico uma vez que não distingue quais folatos são dosados. Ainda assim, o MM é o único método oficialmente reconhecido para a análise de folatos. Para isto é avaliada a resposta turbimétrica do crescimento bacteriano de Lactobacillus rhamnosus ao conteúdo de folatos (Arcot \& Shrestha, 2005). No entanto, além de demorado e trabalhoso, a resposta dos microrganismos às diferentes formas de folato não é sempre a mesma. Uma quebra enzimática é essencial antes da quantificação do folato poliglutamato e as condições desta quebra precisam ser otimizadas para cada tipo de alimento (Penteado, 2003).

Hoje em dia, os métodos que permitem diferenciar os diferentes vitâmeros são a HPLC com detecção por fluorescência ou eletroquímica, ou acoplada à espectrometria de massas (Rychlik, 2007). As aplicações de LC/MS têm ganhado espaço especialmente usando ensaios de diluição isotópica para a análise de folatos em alimentos. Estes ensaios são considerados mais precisos já que o uso de padrões internos permitem corregir as perdas dos vitâmeros durante o "clean-up" da amostra e as variações na eficiência de ionização devido as interferências da matriz são compensadas (Pawlosky \& Flanagan, 2001; Pawlosky et al., 2003; Rychlik, 2003, 2004).

Ainda que diversos métodos tenham sido desenvolvidos e aperfeiçoados para a quantificação de folatos nos alimentos, a preparação de amostras e métodos de extração tem recebido pouca atenção.

Usualmente, a extração de folatos é um processo que leva tempo e envolve uma série de passos enzimáticos para liberar os folatos ligados às 
matrizes alimentícias e para deconjugar poliglutamil folatos para monofolatos ou outras formas mais simples. Em cereais fortificados, não é necessária uma extração enzimática uma vez que o AF é a forma de folato predominante já que os cereais contêm baixos níveis de folatos nativos (Pfeiffer et al., 1997). Sendo assim, uma simples extração sólido-líquida pode ser suficiente para recuperar quantitativamente o AF fortificado.

Com relação às novas alternativas de técnicas de extração disponíveis, podemos citar a Extração por Solvente Pressurizado (ESP), que tem recebido atenção recentemente e ganhado ampla aceitação para a extração de compostos orgânicos (Zhou et al., 2010). Esta técnica já foi utilizada para a extração de compostos de vários materiais biológicos, como micotoxinas (Pallaroni et al., 2003), saponinas (Chen et al., 2007), óleos (Dunford \& Zhang, 2003; Freitas et al., 2008), polifenóis (Salces et al., 2001) e lípidios (Toschi et al., 2003).

A técnica de ESP usa pequenas quantidades de solventes convencionais à temperatura $\left(40 \mathrm{a} 200{ }^{\circ} \mathrm{C}\right.$ ) e pressão (até $3000 \mathrm{psi}$ ) elevadas para alcançar a extração quantitativa de amostras sólidas e semi-sólidas em um curto tempo de extração (Coute et al., 1997; Macnaughton et al., 1997; Jansen et al., 2006).

A utilização de solventes a temperatura e pressão elevadas permite a obtenção de melhores rendimentos de extração por diferentes mecanismos:

- uma melhor solubilidade dos analitos;

- uma redução dos efeitos de matriz (forças de atração iônica, forças de van der Waals, ligações hidrogênio, etc.);

- uma diminuição da viscosidade do solvente.

Assim, temos uma melhor penetração e uma melhor difusão do solvente dentro da matriz.

Neste estudo, o método de ESP foi usado pela primeira vez para a extração de $A F$ de farinhas de trigo fortificadas. A quantificação do $A F$ foi realizada por RP-HPLC. O conteúdo de AF foi determinado e comparado com os resultados obtidos com uma extração solído-líquido (ESL) tradicional. 


\section{MATERIAIS E MÉTODOS}

\subsection{Reagentes e Solventes}

\subsubsection{Reagentes}

O AF e teofilina (TP) foram adquiridos na Sigma-Aldrich (Steinheim, Alemanha). Hidrogenofosfato de dipotássio trihidratado foi adquirido da Carlo Erba (Val de Reuil, França). Areia de Fontainebleau foi adquirida da VWR (Leuven, Bélgica).

\subsubsection{Solventes}

A água foi purificada usando um sistema Synergy Milli-Q System (Millipore, Molsheim, França). A acetonitrila (ACN) (Sigma-Aldrich, Steinheim, Alemanha) foi de grau cromatografia líquida de alta eficiência (HPLC). Todos os outros reagentes foram de grau analítico. O ácido acético foi adquirido da Riedelde-Haen/Fluka (Seelze, Alemanha).

\subsubsection{Soluções Estoque}

Todas as amostras padrões de AF foram preparadas sob o abrigo da luz para proteger o AF da degradação oxidativa. As soluções foram preparadas como descrito mais abaixo na seção 1.5 .

\subsubsection{Amostras}

Seis diferentes marcas de farinha de trigo brasileira fortificada com AF foram adquiridas em diferentes supermercados da cidade de São Paulo de julho a dezembro de 2010. 


\subsection{Preparação in-house de Farinhas de Trigo Fortificadas}

Farinhas de trigo não-fortificadas foram adquiridas no comércio varejista de Strasbourg (França) em março de 2011 e serviram como amostras branco. Estas foram fortificadas no laboratório com AF em uma concentração final de $0,75 \mu \mathrm{g} / \mathrm{g} ; 1,5 \mu \mathrm{g} / \mathrm{g}$ e $3,0 \mu \mathrm{g} / \mathrm{g}$. A mistura foi realizada com um agitador Turbula ${ }^{\circledR}$ T 2 F (Wab, Basel, Suíça) em uma velocidade de 72 rpm e com um volume aproximado de $25 \%$ do recipiente. Inicialmente, $300 \mathrm{mg}$ de AF foram misturados a $200 \mathrm{~g}$ de farinha de trigo não-fortificada por $17 \mathrm{~min}$, resultando assim em uma concentração de $1.500 \mu \mathrm{g} / \mathrm{g}$ (farinha A). Em seguida, $10 \mathrm{~g}$ da farinha $\mathrm{A}$ foram misturados com $90 \mathrm{~g}$ de farinha de trigo não-fortificada por $5 \mathrm{~min}$, resultando em uma concentração de $150 \mu \mathrm{g} / \mathrm{g}$ (farinha B). Finalmente, $1 \mathrm{~g}$ da farinha $B$ foi misturada com $99 \mathrm{~g}$ de farinha de trigo não-fortificada por $5 \mathrm{~min}$, resultando em uma concentração final de $1,5 \mu \mathrm{g} / \mathrm{g}$. Similarmente, uma concentração final de $0,75 \mu \mathrm{g} / \mathrm{g}$ e $3,0 \mu \mathrm{g} / \mathrm{g}$ foi feita misturando $0,5 \mathrm{~g}$ e $2,0 \mathrm{~g}$ da farinha B com 99,5 g e 98,0 g de farinha de trigo não-fortificada por $5 \mathrm{~min}$, respectivamente. Todas as preparações foram realizadas em triplicata.

\subsection{Extração do Ácido Fólico da Farinha de Trigo Fortificada}

\subsubsection{Extração Sólido/Líquido (ESL)}

O protocolo de extração sólido/líquido foi adaptado de Alaburda et al. (2008). Três gramas de farinha de trigo fortificada com AF foram extraídos com 30 $\mathrm{mL}$ de tampão fosfato $0,1 \mathrm{M} \mathrm{pH}$ 9. A mistura foi agitada por $30 \mathrm{~min}$ em agitador rotacional a temperatura ambiente e em seguida centrifugada a $3.500 \mathrm{rpm}$ por 15 min. O sobrenadante foi guardado e o "pellet" foi re-extraído por 3 vezes (total de 4 extrações) seguindo o mesmo procedimento. Cada sobrenadante foi filtrado com membrana PVDF hidrofílica 0,22 $\mu \mathrm{m}$ (Millipore, Carrigtwohill, Irlanda) antes da análise cromatográfica. As extrações foram realizadas em triplicata para cada amostra individual de farinha de trigo. 


\subsubsection{Extração por Solvente Pressurizado (ESP)}

A Extração por Solvente Pressurizado foi realizada em um equipamento Dionex PLE 350 (Dionex, Sunnyvale, CA, EUA). Três gramas de farinha de trigo foram misturadas homogeneamente com $41 \mathrm{~g}$ de areia $\mathrm{e}$ colocados dentro de uma célula de extração de aço inoxidável de $22 \mathrm{~mL}(\mathrm{~L} \times \varnothing$ : $52 \mathrm{~mm} \times 28 \mathrm{~mm})$. Um volume de $50 \mu \mathrm{L}$ de uma solução de TP $(100 \mu \mathrm{g} / \mathrm{mL})$ foi adicionado a cada célula de extração. Um filtro de celulose foi colocado na saída da célula de extração. O mesmo tampão fosfato previamente usado na ESL foi empregado na ESP. Foi utilizada uma temperatura de extração de $40^{\circ} \mathrm{C}$ (temperatura mínima do equipamento). A pressão de extração foi de $10 \mathrm{MPa}$. Cada etapa de extração compreendeu três ciclos com 3 min de tempo estático. Após cada ciclo, a célula foi lavada com novo solvente de extração ( $20 \%$ do volume da célula de extração). Finalmente, após o terceiro tempo estático, foi feita a purga da célula de extração com um fluxo de nitrogênio (10 MPa por $60 \mathrm{~s}$ ). $\mathrm{O}$ tempo total de extração levou $15 \mathrm{~min}$. A mesma amostra foi re-extraída 2 vezes (sem acrescentar TP). Cada extrato (aproximadamente $30 \mathrm{~mL}$ ) foi recuperado em diferentes frascos e filtrados com membrana PVDF hidrofílica 0,22 $\mu \mathrm{m}$ (Millipore, Carrigtwohill, Irlanda) antes da análise cromatográfica. As extrações foram realizadas em triplicata para cada amostra individual de farinha de trigo.

\subsection{Cromatografia Líquida de Alta Eficiência (HPLC)}

As separações cromatográficas foram realizadas em cromatógrafo líquido Beckmann Coulter System Gold HPLC system (Palo Alto, 163 CA, EUA) equipado com módulo programável da bomba 126, injetor automático 508, detector de arranjo de diodos 168 [DAD] UV-vis e software 32 Karat, versão 5.0. Foi utilizada uma coluna analítica cromatrográfica Agilent Zorbax Eclipse XDBPhenyl ( $250 \times 4,6 \mathrm{~mm}$; tamanho de partícula de $5 \mu \mathrm{m})$ a $20^{\circ} \mathrm{C}\left( \pm 2^{\circ} \mathrm{C}\right)$. Um gradiente de eluição com acetonitrila e água acidificada com ácido acético $(\mathrm{pH}$ $2,8)$ foi utilizado. O fluxo foi de $1,0 \mathrm{~mL} / \mathrm{min}$. O gradiente utilizado está resumido na TAB. 11. Um volume de injeção de $20 \mu \mathrm{L}$ foi utilizado. A detecção foi realizada a $280 \mathrm{~nm}$. A fim de controlar o sistema analítico, água (controle negativo) e solução aquosa em tampão fosfato de $\operatorname{AF}(0,15 \mu \mathrm{g} / \mathrm{mL})$ foram injetadas durante a análise das amostras a cada 10 injeções. A identificação do AF foi feita pela comparação 
do tempo de retenção e do espectro de absorção UV com padrão de AF (detecção DAD).

TABELA 11. Gradiente de eluição em cromatografia analítica (Método 5)

\begin{tabular}{ccc}
\hline Tempo $(\min )$ & $\% \mathrm{ACN}$ & $\% \mathrm{H}_{2} \mathrm{O}(\mathrm{pH} 2,8)$ \\
\hline 0 & 2 & 98 \\
15 & 2 & 98 \\
35 & 25 & 75 \\
43 & 25 & 75 \\
44 & 2 & 98 \\
56 & 2 & 98 \\
\hline
\end{tabular}

\subsection{Análise Quantitativa de AF em Farinhas de Trigo Fortificadas}

A quantificação do AF foi realizada por padronização externa com solução padrão de AF para o método ESL e por padronização interna com solução padrão de AF e TP para o método ESP. Para ambas as padronizações, uma solução padrão de $\operatorname{AF}(1.000 \mu \mathrm{g} / \mathrm{mL})$ foi inicialmente preparada com tampão fosfato $0,1 \mathrm{M} \mathrm{pH} \mathrm{9,0} \mathrm{e} \mathrm{então} \mathrm{diluída} \mathrm{para} \mathrm{obter} \mathrm{uma} \mathrm{solução} \mathrm{de} \mathrm{concentração} \mathrm{final}$ de $2 \mu \mathrm{g} / \mathrm{mL}$. Esta última foi utilizada para preparar curva de calibração com seis diferentes pontos, na faixa de 0,02 a 0,3 $\mu \mathrm{g} / \mathrm{mL}$. Na padronização interna, o padrão interno TP foi adicionado em cada solução padrão de AF para obter uma concentração final de $0,16 \mu \mathrm{g} / \mathrm{mL}$. Todas as soluções de calibração padrão foram preparadas sob o abrigo da luz e armazenadas em frascos âmbar para proteger o AF da degradação oxidativa da luz.

O limite de detecção (LDD) foi definido como a menor concentração do analito que apresentasse uma razão sinal/ruído $(\mathrm{S} / \mathrm{N})$ de 3 . O limite de quantificação (LDQ) foi definido como a menor concentração do analito que apresentasse uma razão sinal/ruído (S/N) de 10.

As amostras de farinha de trigo foram analisadas em triplicata. As concentrações de AF foram expressas em $\mu \mathrm{g} / \mathrm{g}$ de farinha de trigo. Todos os resultados foram expressos como média \pm desvio padrão (DP). Para a 
comparação das médias aritméticas, empregou-se o teste t de Student e o teste de Tukey usando o software Statgraphics Plus para Windows. Adotou-se o nível de significância de $5 \%$ de probabilidade $(p<0,05)$. 


\section{RESULTADOS E DISCUSSÃO}

\subsection{Análise Cromatográfica}

Muitos trabalhos publicados (Osseyi et. al, 1998; Alaburda et. al, 2008; Cheung et. al, 2008; Patring et. al, 2009) utilizaram uma coluna cromatográfica C18 para análise e quantificação de ácido fólico em cromatografia de fase reversa.

No presente trabalho, foi testada igualmente uma coluna $\mathrm{C} 18$ e também outros tipos de coluna, como amino $\left(\mathrm{NH}_{2}\right)$, ciano $(\mathrm{CN})$ e fenil. Resumidamente, foram encontrados os seguintes resultados com as colunas testadas:

- uma coluna analítica CN (Macherey-Nagel; 125 x 3,0 mm; tamanho de partícula de $3 \mu \mathrm{m}$ ) não mostrou uma afinidade suficiente ao AF, sendo assim eluído rapidamente;

- uma coluna analítica $\mathrm{NH}_{2}$ (Nucleosil 100-3 $\mathrm{NH}_{2} ; 125$ x 4,6 mm; tamanho de partícula de $3 \mu \mathrm{m}$ ) mostrou uma forte retenção ao $\mathrm{AF}$, dificultando sua liberação da fase estacionária;

- uma coluna analítica C18 (250 x 4,6 mm; tamanho de partícula de 5 $\mu \mathrm{m}$, Hypersil Gold aQ, Thermo Scientific) apresentou valores de LDD e LDQ para o AF 2 a 3 vezes maiores que aqueles obtidos com a coluna fenil;

- a coluna fenil mostrou valores de LDD e LDQ de 0,12 e 0,4 ng, respectivamente, correspondente a 0,06 e 0,2 $\mu \mathrm{g} / \mathrm{g}$ de farinha de trigo analisada.

Por isso, pode-se concluir que a coluna fenil de escolha, descrita na seção 1.4, apresentou resultados superiores em termos de seletividade e sensibilidade em relação ao $\mathrm{AF}$, com boa resolução e retenção em relação às outras. Por esta razão esta coluna cromatrográfica foi utilizada neste experimento de quantificação do AF logo da ESL e ESP. 
A fim de testar a especificidade do método cromatográfico proposto utilizando a coluna fenil, foram analisados os perfis cromatográficos de soluções padrão de TP e de AF, extratos de farinha de trigo não-fortificada e extratos de farinha de trigo fortificada, com e sem a adição de padrão interno TP (FIG. 45). As soluções padrão de TP e AF apresentaram tempos de retenção de 30,4 e 26,6 min, respectivamente (FIG. 45A).

A análise do perfil cromatográfico de um extrato de farinha de trigo nãofortificada (FIG. 45B e B1) evidenciou a ausência de compostos que eluam com tempos de retenção iguais ao AF e à TP. A análise do perfil cromatográfico de um extrato de farinha de trigo fortificada e com adição do padrão interno TP (FIG. 45C), corroborou este fato uma vez que a TP e o AF se encaixaram naquelas regiões anteriormente vazias do cromatograma. Assim, pode-se demonstrar a especificade do método cromatográfico proposto.

Como proposto por Pfeiffer et al. (1997) e Patring et al. (2009), farinhas de trigo não-fortificadas não apresentam AF naturalmente ou sua concentração é inferior ao limite de detecção do método analítico. Os resultados deste estudo confirmaram esta afirmação. A razão da escolha da TP como padrão interno será abordada mais adiante na seção 2.3 . 

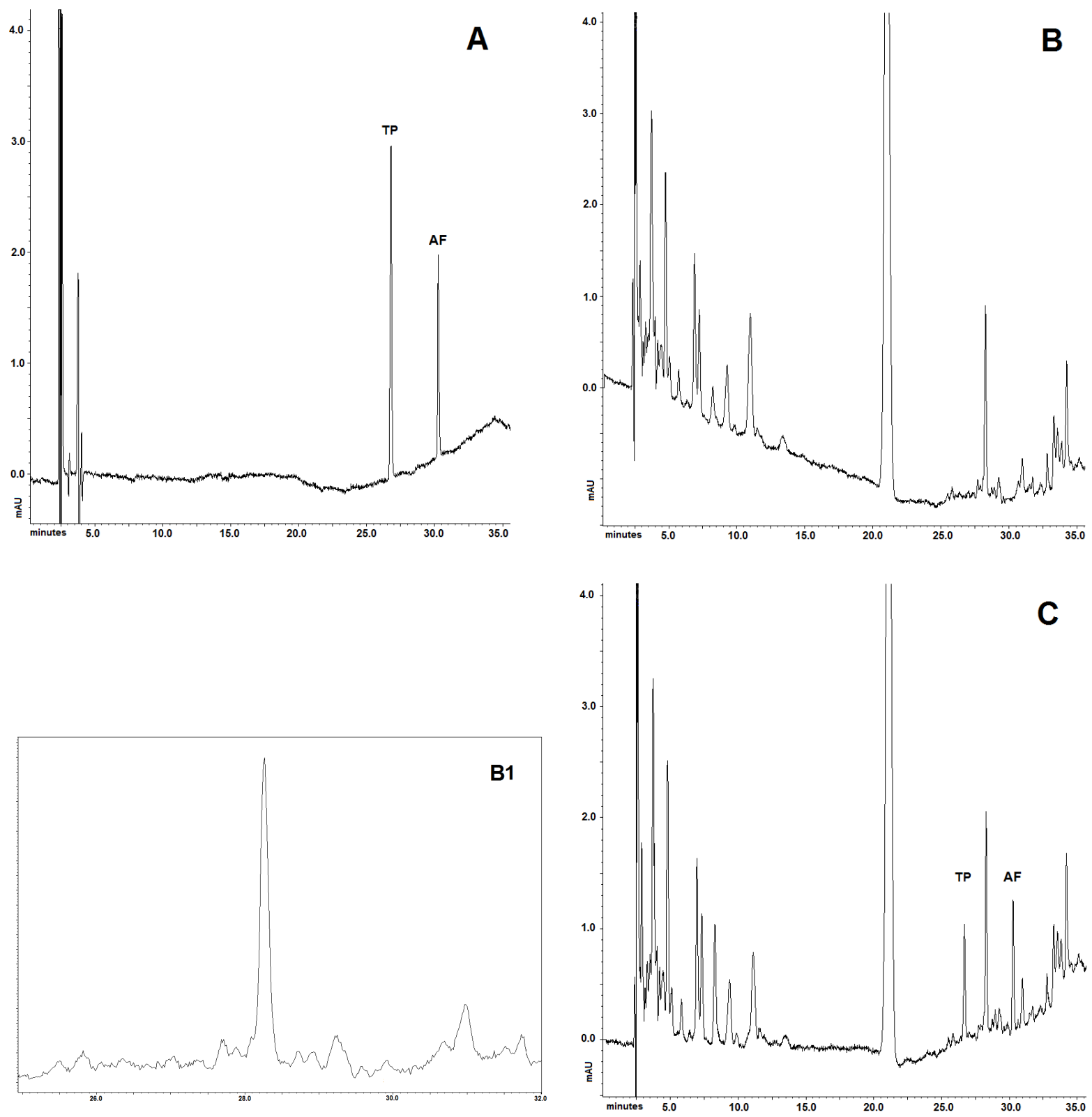

FIGURA 45 - Perfil cromatográfico de soluções padrão de (A) AF e TP, (B) extrato de farinha de trigo não fortificada sem padrão interno, (B1) zoom do perfil cromatográfico de $\mathrm{B}$ compreendendo os tempos de retenção do AF e TP e (C) extrato de farinha de trigo fortificada com adição do padrão interno TP. 


\subsection{Validação dos Resultados}

Referente à análise quantitativa, a linearidade das repostas dos padrões de AF e TP foram avaliados. Duas curvas de calibração foram construídas relacionando às áreas dos picos cromatográficos à concentração das soluções padrão injetadas. A padronização interna com soluções padrão de AF e TP mostrou uma equação da reta $y=1,2573 x+0,0236$, onde y representa a razão da área dos picos do AF e TP e $x$, a razão da concentração entre o AF e a TP $\left(r^{2}=0.999\right)$. Igualmente, a padronização externa com soluções padrão de AF mostrou uma curva de calibração linear $\left(y=73967 x+97,4, r^{2}=0.999\right.$, onde y representa a área do pico do AF e $x$, a concentração do AF). Independentemente do uso de uma padronização externa ou interna, os coeficientes de correlação obtidos $\left(r^{2}\right)$ são superiores a 0,99 , demonstrando que curvas de calibração lineares foram obtidas em toda a faixa de calibração testada. Os baixos valores de LDD e LDQ (respectivamente, 0,12 e $0,4 \mathrm{ng}$ ) obtidos mostram igualmente que o método cromatográfico é igualmente sensível.

\subsection{Otimização da Extração por Solvente Pressurizado (ESP)}

O método de extração por solvente pressurizado foi otimizado fazendo uso de farinhas de trigo fortificadas in house. Contrariamente à ESP, a ESL foi utilizada sem modificações por tratar-se de um método de extração tradicional e serviu de modelo de comparação.

A fim de obter uma ESP eficiente, foi imperativo a otimização de diversos parâmetros da extração, como solvente de extração, célula de extração, temperatura, tempo de extração e número de ciclos de extração.

\section{Solventes de extração}

Em um primeiro momento, foi avaliado o uso de diferentes solventes de extração. Tendo em vista que o AF não é solúvel em solventes orgânicos (por exemplo, metanol e acetonitrila), estes solventes foram logo descartados. Água a pH 7 também não foi o solvente de escolha uma vez que o AF necessita de um pH ácido ou básico para solubilizar-se. O tampão fosfato foi escolhido como solvente de extração em função da alta solubilidade do AF nesse solvente e sua estabilidade nesta condição. 
Em relação à célula de extração, quanto maior o tamanho da célula de extração, maior será o volume de solvente e a quantidade de amostra utilizada. Percebeu-se que uma célula de extração de $22 \mathrm{~mL}$ de volume permitiu uma melhor passagem do solvente de extração que uma célula de extração de $10 \mathrm{~mL}$. Ainda assim, a quantidade de amostra foi pequena $(3 \mathrm{~g})$.

\section{Temperatura}

Outro parâmetro importante durante o processo é a temperatura. Geralmente a ESP utiliza altas temperaturas (100 a $200^{\circ} \mathrm{C}$ ) para obter um melhor rendimento de extração dos compostos de interesse. Diferentes temperaturas de extração (40 to $80^{\circ} \mathrm{C}$ ) foram investigadas. Neste trabalho, um incremento de temperatura não acarretou um melhor rendimento de extração do AF. Temperaturas superiores a $50^{\circ} \mathrm{C}$ desencadearam uma forte agregação das partículas de farinha de trigo e a formação de uma mistura compacta, gerando pouco volume de extração e um extrato turvo e viscoso. Como resultado, o aumento na temperatura de extração levou a uma dificuldade de filtração dos extratos para a análise em HPLC. Este fato poderia ser explicado devido ao fato da farinha de trigo conter partículas muito finas que sobre pressão podem aderirse fortemente entre si a temperaturas elevadas. Igualmente não foi recomendada a utilização de uma temperatura inferior a $40^{\circ} \mathrm{C}$ (temperatura mínima termostatizada do equipamento) devido à variação sazonal da temperatura no laboratório, comprometendo a repetabilidade dos experimentos.

Em função desta obtenção de extratos pouco límpidos foi recomendável à utilização de um agente dispersante para ajudar no processo de extração. Neste estudo, a areia foi utilizada como agente dispersante, a qual foi misturada de forma homogênea à farinha de trigo. Esta mistura homogênea apresentou vantagens em relação à disposição em sanduíche de uma camada de agente dispersante seguida de uma camada de amostra e uma segunda camada de agente dispersante. $\mathrm{O}$ uso de areia misturada homogeneamente à farinha de trigo assegurou uma mistura porosa, facilitando o fluxo de solvente pela amostra através da célula de extração e também permitiu reduzir o volume de solvente utilizado durante a extração. Pallaroni et al. (2003) igualmente enfatizaram a necessidade de um agente dispersante (terra de diatomácea) para minimizar a obtenção de extratos turvos com temperaturas crescentes. 


\section{Quantidade de ciclos de extração}

Também foi investigado o número de ciclos de extração necessários para alcançar uma extração total do AF. Para isso, os rendimentos foram calculados logo de cada extração com os diferentes ciclos de extração testados.

Um único ciclo com tempo estático de $10 \mathrm{~min}$, permitiu apenas a recuperação de $70 \%$ do AF na primeira extração (FIG. 46). Neste caso foram necessárias três extrações consecutivas da mesma célula de extração para a extração completa do AF.

De igual maneira, o uso de dois ciclos com tempo estático de $5 \mathrm{~min}$ também não permitiu uma extração completa do $\mathrm{AF}$ em um único passo de extração (FIG. 46). Entretanto, diferentemente na condição anterior, conseguiu-se em torno de $85 \%$ do AF na primeira extração, sendo necessárias ainda três extrações consecutivas da mesma célula de extração para a extração completa do AF.

O número de ciclos de extração ideal foi encontrado com um procedimento de extração contendo três ciclos com 3 min tempo estático. Nesta condição, assegurou-se uma recuperação total do $\mathrm{AF}$ em apenas uma única extração (FIG. 46). Para isso, o volume de lavagem inicial foi dividido entre os 3 ciclos, introduzindo desta forma novo solvente durante o processo de extração, permitindo um equilíbrio de extração favorável. 


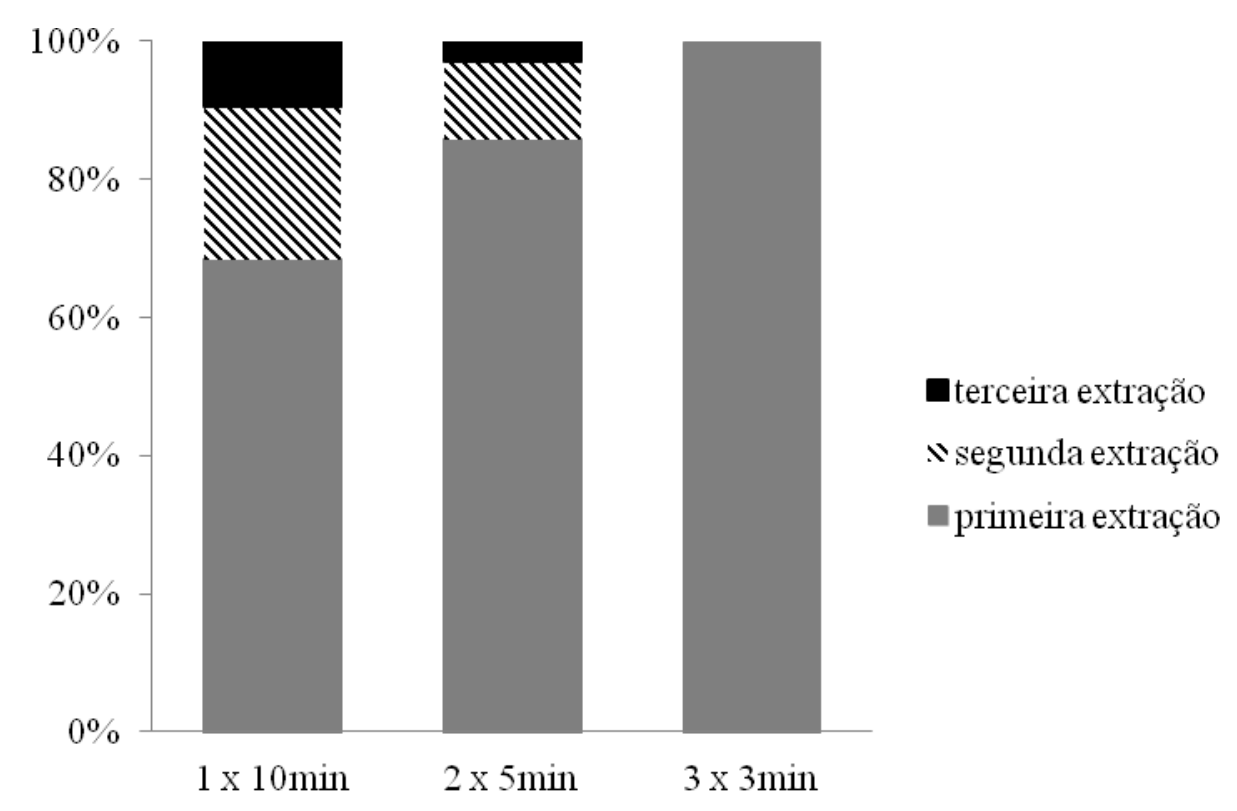

\section{Tempo estático}

FIGURA 46 - Porcentagem de recuperação do AF após a otimização da ESP.

Vale ressaltar que na ESP o volume de extração obtido é variável em função de fatores como a amostra analisada, uso de agentes dispersantes, tamanho da célula de extração, pressão de extração, etc. Assim, como o volume de extração obtido foi em torno de $30 \mathrm{~mL}$, foi utilizado um padrão interno para quantificar o AF de maneira correta.

Pallaroni et al. (2003) também ressaltaram a necessidade do uso de um padrão interno (zearalanona) para a quantificação da micotoxina zearalenona em amostras de trigo e milho devido à variação do volume de solvente recuperado pelo método ESP.

Neste estudo, o padrão interno utilizado foi a teofilina (TP). A TP foi escolhida como padrão interno por apresentar estrutura química e espectro de absorção máximo similares ao AF (FIG. 47). Além disso, a TP também apresentou ótima solubilidade no tampão fosfato utilizado como solvente de extração. 

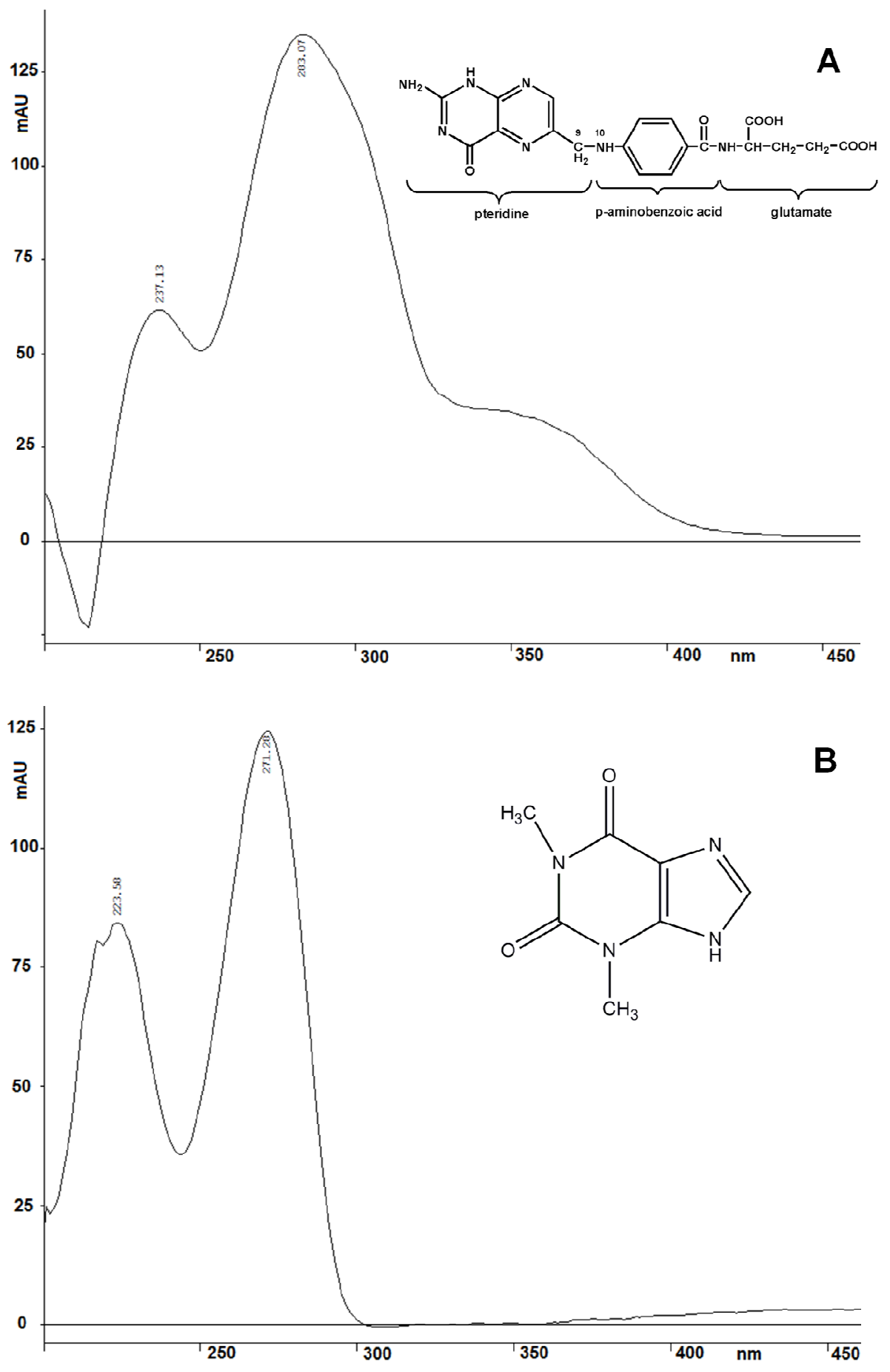

FIGURA 47. Estrutura química e espectro UV do AF $(A)$ versus estrutura química e espectro UV da TP. 
Assim, a condição de trabalho otimizada para a ESP foi encontrada uma célula de $22 \mathrm{~mL}$, a qual foi preenchida com uma mistura homogênea de farinha de trigo e areia. Um tampão fosfato foi utilizado como solvente de extração e foi aplicada um a condição de extração compreendendo três ciclos com 3 min de tempo estático a uma temperatura de $40^{\circ} \mathrm{C}$.

\subsection{Comparação da ESP e da ESL}

Uma vez que o método ESP foi otimizado, este foi comparado ao ESL quanto ao rendimento de extração do $\mathrm{AF}$ de farinhas de trigo fortificadas in house. $O$ método tradicional de ESL foi utilizado com modificações (como descrito na seção 1.3.1). A fim de comparar os métodos ESP e ESL foram utilizadas farinhas de trigo fortificadas in house com três diferentes concentrações de AF $(0,75 ; 1,5$ e $3,0 \mu \mathrm{g} / \mathrm{g})$.

Os resultados mostrados na TAB. 12 representam os valores de recuperação de uma única extração pelo método de ESP e da soma de três extrações do método ESL. Os valores de recuperação variaram na faixa de 92,7 a $101,0 \%$. Não houve diferença significativa $(p \geq 0,05)$ nem entre os diferentes níveis de fortificação para um mesmo método de extração nem entre os dois diferentes métodos de extração testados (ESP e ESL), indicando que ambos os métodos de extração são eficientes para extrair o AF de farinhas de trigo.

Da mesma maneira, ambos os métodos de extração mostraram baixos valores de desvio padrão (DP) assim como baixos coeficientes de variação (na faixa de 1,7 a $6,4 \%)$. 
TABELA 12 - Valores de rendimento do AF extraído por ESP e ESL de farinhas de trigo fortificadas de referência.

\begin{tabular}{cccc}
\hline $\begin{array}{c}\text { Concentração } \\
\text { teórica de } \mathrm{AF}(\mu \mathrm{g} / \mathrm{g})\end{array}$ & $\begin{array}{c}\text { Método de } \\
\text { Extração }\end{array}$ & $\begin{array}{c}\text { Concentração de } \\
\mathrm{AF}(\mu \mathrm{g} / \mathrm{g})\end{array}$ & Recuperação (\%) \\
\hline \multirow{2}{*}{0,75} & $\mathrm{ESP}$ & $0,76 \pm 0,01$ & $101,0 \pm 1,7$ \\
& $\mathrm{ESL}^{\mathrm{a}}$ & $0,73 \pm 0,01$ & $97,3 \pm 2,0$ \\
\hline \multirow{2}{*}{1,5} & $\mathrm{ESP}$ & $1,51 \pm 0,10$ & $101,0 \pm 6,4$ \\
& $\mathrm{ESL}^{\mathrm{a}}$ & $1,39 \pm 0,06$ & $92,7 \pm 3,9$ \\
\hline \multirow{2}{*}{3,0} & $\mathrm{ESP}^{2}$ & $2,95 \pm 0,05$ & $98,3 \pm 1,7$ \\
& $\mathrm{ESL}^{\mathrm{a}}$ & $2,93 \pm 0,14$ & $97,7 \pm 5,5$ \\
\hline
\end{tabular}

Valores expressos como média \pm desvio padrão $(n=3)$. ${ }^{a}$ Resultado de três ESL sucessivas.

Também foi comparado o número de extrações necessárias para a extração total do AF usando os dois métodos de extração (ESL e ESP). Para isso, foram realizadas extrações sucessivas da mesma célula de extração, no caso da ESP, e do mesmo tubo de extração, no caso da ESL. Assim, percebeu-se que os dois métodos de extração (ESL e ESP) apresentaram diferenças em relação à quantidade de $\mathrm{AF}$ recuperadas logo da primeira extração.

O procedimento otimizado de ESP (três ciclos com 3 min tempo estático) permitiu a extração do conteúdo total do AF logo da primeira extração das amostras de farinha de trigo fortificada (FIG. 48A). Independentemente do nível de fortificação da farinha de trigo $(0,75 ; 1,5$ ou $3,0 \mu \mathrm{g} / \mathrm{g})$, obteve-se uma extração total do AF. As quantidades obtidas do AF abaixo do LDQ na segunda extração confirmam estes resultados. 

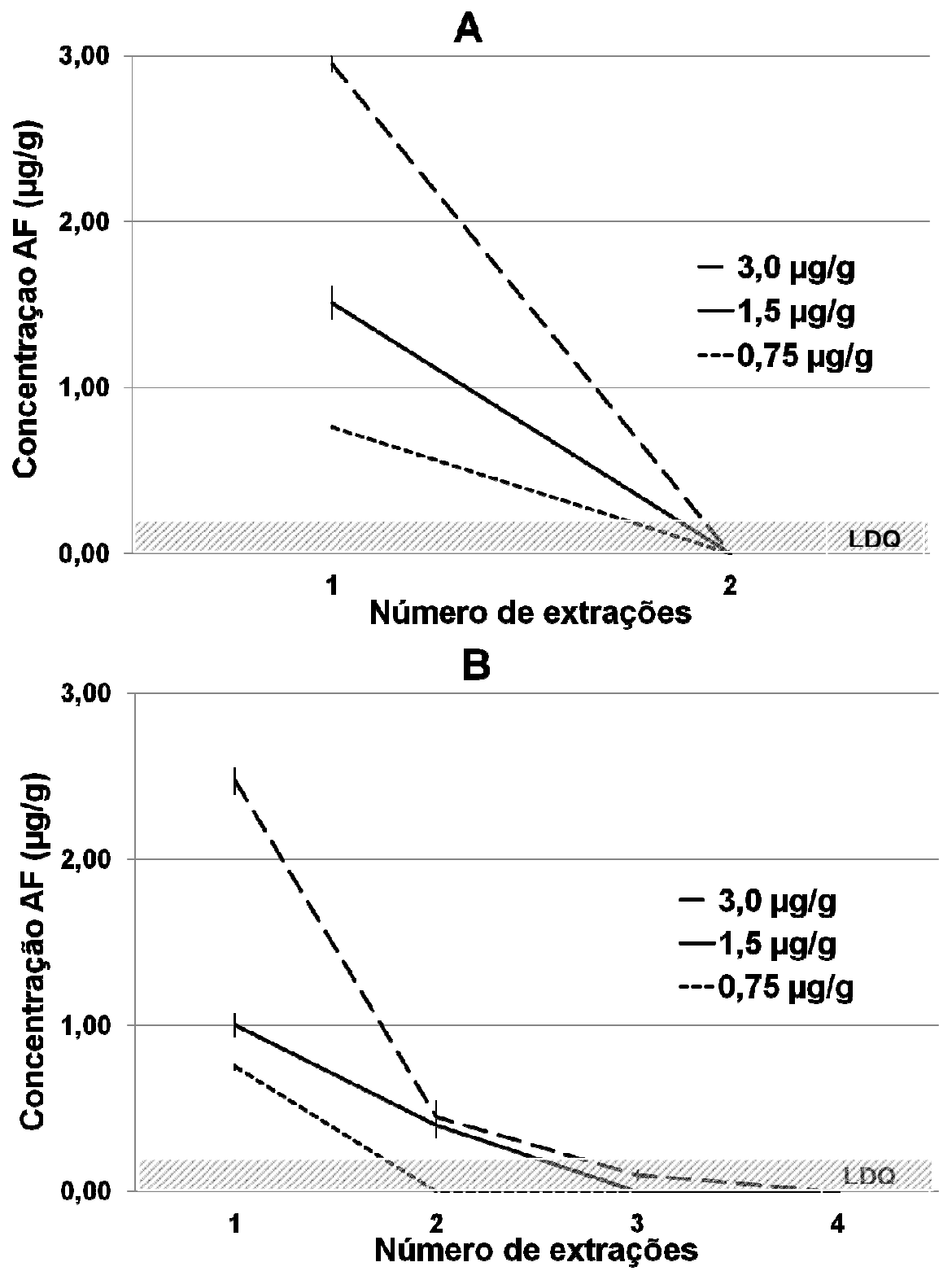

FIGURA 48 - Conteúdo de AF recuperado de extrações sucessivas de farinhas de trigo fortificadas in house: (A) método ESP; (B) método ESL.

Analisando os resultados da ESL, uma, duas ou até mesmo três extrações sólido/líquido sucessivas, cada uma com $30 \mathrm{~mL}$ de solvente, foram necessárias para uma recuperação total do $\mathrm{AF}$ da farinha de trigo, dependendo do nível de fortificação (FIG. 48B). Embora uma única extração sólido/líquido recuperasse quase todo o $\mathrm{AF}$ de farinhas de trigo fortificadas com $0,75 \mu \mathrm{g} / \mathrm{g}$ de 
AF, foram necessárias três extrações sólido/líquido sucessivas para recuperar todo o AF de farinhas de trigo fortificadas com 3,0 $\mu \mathrm{g} / \mathrm{g}$ (FIG. 48B).

Gregory (1989) também sinalizou que um duplo procedimento de extração (isto é, o resíduo da primeira extração é ressuspendido e centrifugado) rendeu mais $\mathrm{AF}$ que um procedimento rotineiro de uma única extração. Assim, o método ESL mostrou-se um procedimento de extração mais demorado, já que dependendo do nível de fortificação da farinha de trigo foram necessárias até três extrações consecutivas para esgotar o conteúdo de AF. Além disso, é importante frisar que cada extrato sólido-líquido (primeira, segunda e terceira extração da mesma amostra) teve que ser analisado individualmente em HPLC para quantificação total do AF. O pooling dos três extratos sólido-líquido juntos (primeira, segunda e terceira extração da mesma amostra) foi inviável, pois acarretaria um fator de diluição de 3 vezes, o que poderia comprometer os valores de LDD e LDQ. Ainda se isso fosse feito, seria imperativo o uso de um procedimento de concentração (por exemplo, evaporação) que demoraria ainda mais a análise uma vez que um tampão fosfato em solução aquosa foi empregado.

Foi por esta razão, que contrariamente à ESP, o uso de um padrão interno não foi utilizado para o método tradicional de ESL já que extrações sucessivas foram necessárias para recuperar todo o AF das amostras de farinha de trigo fortificadas. Devido à alta solubilidade da TP no tampão fosfato, toda a TP seria extraída na primeira extração impossibilitando a quantificação do AF de cada extração individual. Assim, uma padronização externa utilizando o AF como padrão foi utilizada para o método de ESL.

Concluiu-se que a ESP apresentou vantagens em relação à ESL para a extração do $\mathrm{AF}$ em farinhas de trigo fortificadas. Uma única extração ESP permitiu a extração completa do $\mathrm{AF}$ independentemente do nível de fortificação da farinha de trigo. Por outro lado, a ESL necessitou de extrações sucessivas das amostras de farinha de trigo a fim de alcançar a exaustão completa do AF. 


\subsection{Quantificação do AF em Farinhas de Trigo Fortificadas}

\section{Comerciais}

Logo da validação e otimização dos dois métodos de extração, ESP e ESL, em farinhas de trigo fortificadas de referência, foi feito um estudo com amostras de farinha de trigo comercialmente disponíveis. Analisando os resultados obtidos com o método de ESP, as quantidades de AF variaram de 1,66 a $3,23 \mu \mathrm{g} / \mathrm{g}$ das amostras de farinha de trigo comerciais (TAB. 13). Resultados similares foram encontrados utilizando o método de ESL $(1,60$ a 3,25 $\mu \mathrm{g} / \mathrm{g})(\mathrm{TAB}$. 13).

TABELA 13 - Conteúdo de AF extraída por ESP e ESL de seis diferentes farinhas de trigo fortificadas comerciais analisadas por HPLC.

Conteúdo de AF em farinhas de trigo comerciais $(\mu \mathrm{g} / \mathrm{g})$

\begin{tabular}{clllllll}
\hline $\begin{array}{c}\text { Método de } \\
\text { Extração }\end{array}$ & I & II & III & IV & V & VI
\end{tabular}

ESP $\quad 3,23 \pm 0,10 \quad 3,05 \pm 0,02 \quad 2,18 \pm 0,13 \quad 1,94 \pm 0,15 \quad 1,78 \pm 0,22 \quad 1,66 \pm 0,04$

ESL $^{\mathbf{a}} \quad 3,24 \pm 0,36 \quad 3,25 \pm 0,16 \quad 2,32 \pm 0,14 \quad 1,88 \pm 0,13 \quad 1,84 \pm 0,20 \quad 1,60 \pm 0,10$

Valores expressos como média \pm desvio padrão $(n=3) .{ }^{a}$ Resultado de três ESL sucessivas.

Em todas as amostras de farinha de trigo comerciais analisadas, o conteúdo expresso na embalagem foi excedido. Dentre as farinhas de trigo fortificadas analisadas, duas amostras (I, II) apresentaram uma fortificação em excesso superior em duas vezes o nível de fortificação obrigatória $(1,50 \mu \mathrm{g} / \mathrm{g})$ estabelecidas pela (ANVISA) (Brasil, 2002) (TAB. 13). Este fato também foi constatado nos estudos de Osseyi et al. (1998) e Rychlik (2003). Estes constataram uma fortificação em excesso de produtos cereais fortificados e sugeriram que este fato pode ser uma estratégia da indústria de alimentos a fim 
de garantir a concentração final estabelecida pela legislação e compensar uma possível perda de AF durante o processo de fortificação e/ou durante 0 processamento do alimento.

A Resolução RDC No. 269 (Brasil, 2005) preconiza a fortificação de alimentos com vitaminas e minerais até $100 \%$ da ingestão diária de referência, o que para o AF equivale a 2,40 $\mu \mathrm{g} / \mathrm{g}$. Como corroborado, algumas amostras de farinha de trigo excederam este valor (TAB. 13). Ainda assim, é sabido e documentado a nível mundial que os níveis recomendados de AF para fins de fortificação são extremamente inferiores ao limite superior tolerável de ingestão de $1.000 \mu \mathrm{g}$ por dia para adultos (SCF, 2000; Otten et al., 2006).

A comparação do conteúdo de $\mathrm{AF}$ ( $\mu \mathrm{g} / \mathrm{g}$ de farinha de trigo) encontrado com ambos os métodos de extração (ESP e ESL) mostra que os dados são muito consistentes (TAB. 13). Foi encontrada uma alta correlação $\left(r^{2}=0,9835\right)$ dos resultados obtidos (FIG. 49) $(\mathrm{p} \geq 0,05)$.

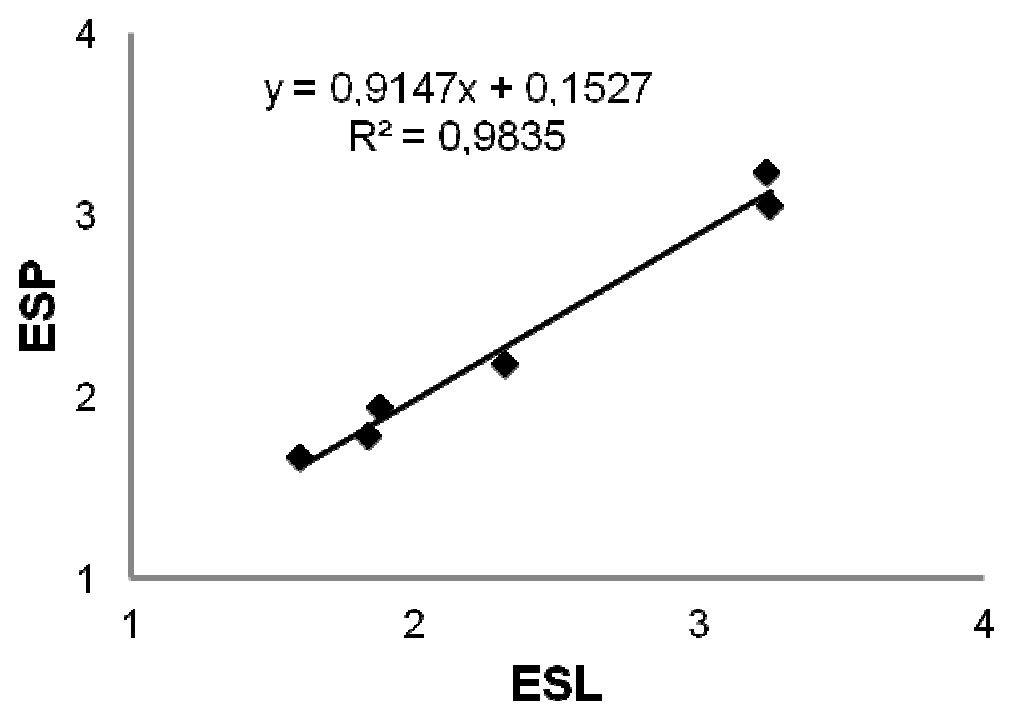

FIGURA 49 - Correlação do conteúdo de AF extraído de farinhas de trigo comerciais pelo método ESP e ESL. 
Os resultados para cada amostra comercial de farinha de trigo fortificada obtidos com a ESP e ESL não mostraram diferença significativa $(p \geq 0,05)$ no conteúdo de $A F$ quantificado. Para ambos os métodos foram encontrados as mesmas quantidades de AF para cada uma das amostras comerciais de farinha de trigo analisadas, mostrando que as duas técnicas de extração obtêm resultados comparáveis. 


\section{CONCLUSÕES}

A determinação precisa do AF em alimentos fortificados, e em especial em farinha de trigo fortificada, é importante para o cumprimento da legislação vigente tendo em vista o interesse nutricional crescente deste elemento para a população em geral. Assim, pode-se concluir que:

- o método de ESP é um método simples, automático, rápido e eficiente para a extração de $A F$ de farinhas de trigo fortificadas;

- a automatização da ESP permite a redução de mão-de-obra e minimização de erros de manipulação, pois a operação consiste apenas da preparação das células de extração;

- um volume mínimo de solvente de apenas $30 \mathrm{~mL}$ foi necessário para a ESP, independentemente do nível de fortificação da farinha de trigo;

- os materiais de extração da ESP são reutilizáveis, assim poderia ser feita uma economia na compra de consumíveis;

- um único procedimento ESP (15 min) foi suficiente para extrair todo o AF de farinhas de trigo fortificadas;

- a ESL envolveu diversas etapas (extração, centrifugação, resuspensão) que retardaram o processo e a quantidade de solvente e consumíveis utilizadas depende do nível de fortificação da farinha inicial;

- a ESP foi aplicada com sucesso a seis amostras comerciais de farinha de trigo brasileiras;

- os resultados obtidos por ESP e ESL mostraram uma grande consistência. 


\section{CAPÍTULO 4: QUANTIFICAÇÃO DO ÁCIDO FÓLICO EM FARINHAS DE TRIGO FORTIFICADAS IRRADIADAS E EM PÃES PRODUZIDOS COM FARINHAS DE TRIGO FORTIFICADAS IRRADIADAS}

\section{MATERIAIS E MÉTODOS}

\subsection{Reagentes e Solventes}

\subsubsection{Reagentes}

O AF foi adquirido da Sigma-Aldrich (Steinheim, Alemanha). Hidrogenofosfato de dipotássio trihidratado foi adquirido da Carlo Erba (Val de Reuil, França). Areia de Fontainebleau foi adquirida da VWR (Leuven, Bélgica).

\subsubsection{Solventes}

A água foi purificada usando um sistema Synergy Milli-Q System (Millipore, Molsheim, França). A acetonitrila (ACN) (Sigma-Aldrich, Steinheim, Alemanha) foi de grau cromatografia líquida de alta eficiência (HPLC). Todos os outros reagentes foram de grau analítico. $O$ ácido acético foi adquirido da Riedelde-Haen/Fluka (Seelze, Alemanha).

\subsubsection{Soluções estoque}

Todas as amostras padrões de AF foram preparadas sob o abrigo da luz para proteger o AF da degradação oxidativa. As soluções foram preparadas como descrito no item 1.8 . 


\subsection{Preparação in-house de farinhas de trigo fortificadas}

Farinhas de trigo não-fortificadas foram adquiridas no comércio varejista de Strasbourg (França) em março de 2011 e serviram como amostras branco. Estas foram fortificadas no laboratório com AF com uma concentração final de aproximadamente $3,0 \mu \mathrm{g} / \mathrm{g}$. As misturas foram realizadas como descrito no item 1.2 do Capítulo 3 com um agitador Turbula® T 2 F (Wab, Basel, Suíça)

\subsection{Titulação de Karl Fischer}

A determinação de água pelo método de Karl Fischer foi realizada utilizando um titulador TitroMatic KF 1S-2B (Crison, Barcelona, Espanha). Dois gramas de farinha de trigo foram adicionadas em um volume final de $50 \mathrm{~mL}$ de metanol e agitadas por $15 \mathrm{~min}$ a $50^{\circ} \mathrm{C}$. Depois do res friamento até temperatura ambiente e sedimentação da farinha de trigo, $3 \mathrm{~mL}$ do sobrenadante foram utilizados para a titulação durante $5 \mathrm{~min}$. Uma amostra controle de metanol puro foi utilizada.

\subsection{Processamento por Radiação lonizante}

As amostras de farinha de trigo fortificadas com AF e amostras de AF em pó foram irradiadas com um acelerador de elétrons Van de Graaff E-beam, 2 MeV (Vivirad High Voltage, Handschuheim, França) com $100 \mu \mathrm{A}$ de corrente, 20 $\mathrm{cm}$ de largura de feixe e taxa de dose de aproximadamente $2 \mathrm{kGy} / \mathrm{s}$. As doses de radiação aplicadas foram 0 (controle); 1,0; 3,0; 5,0; 7,0 e 10,0 kGy. As doses absorvidas foram monitoradas com dosímetros radiocrômicos FWT 60.00 (Far West Technology, Goleta, CA), previamente calibrados com dosímetros de alanina (Aérial, Illkirch, França) (Kuntz et al., 1996). A uniformidade de dose foi de aproximadamente $10 \%$ dentro da amostra e esta foi alcançada pelo uso de uma lâmina de espalhamento de cobre de $100 \mu \mathrm{m}$ de espessura (Kuntz et al., 1990). Durante a irradiação, condições padrões de temperatura e pressão foram utilizadas $\left(25^{\circ} \mathrm{C}\right.$ e $\left.0,1 \mathrm{MPa}\right)$. 


\subsection{Fabricação do pão}

A fabricação de pães foi realizada automaticamente com o uso de uma máquina de pão caseira (Moulinex Home Bread). Para a fabricação de um pão de $500 \mathrm{~g}$ foram utilizados os seguintes ingredientes: água $(210 \mathrm{~mL})$, sal $(5,0 \mathrm{~g})$, farinha de trigo (360 g) e levedura (2,5 g). O programa de fabricação dos pães levou um tempo total de $3 \mathrm{~h} 28$ min e envolveu as seguintes etapas: mistura ( 5 $\mathrm{min}$ ), repouso (5 $\mathrm{min}$ ), segunda mistura (20 min), fermentação inicial (39 min), terceira mistura (10 s), fermentação intermediária (30,5 min), quarta mistura (10 s), fermentação final (59,5 min), cocção (48 min). A temperatura máxima alcançada na máquina de pão foi de $135^{\circ} \mathrm{C}$. No final da cocção, os pães foram imediatamente retirados da máquina e resfriados antes da pesagem. Os pães foram embalados e armazenados ao abrigo da luz a temperatura ambiente. A análise ocorreu no máximo no dia seguinte ao dia da preparação.

\subsection{Moagem Criogênica}

Fatias das amostras de pão foram colocadas dentro da cubeta do moinho criogênico (6870 Freezer/Mill, Spex SamplePrep, Metuchen, EUA) cheia de nitrogênio líquido. O método de criomoagem utilizado compreendeu três ciclos, detalhados a seguir: 2 min de pré-congelamento dentro do nitrogênio líquido, 3 min de moagem e ainda 1 min de congelamento. Depois de moídas, as amostras foram recuperadas na forma de pó fino, pesadas e armazenadas até o momento da extração por ESP. 


\subsection{Extração do AF de amostras de Farinha de Trigo Fortificada e} de Pães

\subsubsection{Extração Sólido/Líquido (ESL)}

O protocolo de extração sólido/líquido empregado foi idêntico ao utilizado no Capítulo 3.

\subsubsection{Extração por Solvente Pressurizado (ESP)}

A Extração por Solvente Pressurizado foi realizada como descrito no item 1.3.2 do Capítulo 3, com modificações. Três gramas de amostra (farinha de trigo ou pão moído criogênicamente) foram misturadas homogeneamente com 41 $\mathrm{g}$ de areia e colocados dentro de uma célula de extração de aço inoxidável de 22 $\mathrm{mL}(\mathrm{L} \times \varnothing: 52 \mathrm{~mm} \times 28 \mathrm{~mm})$. Sabendo que a densidade do extrato era em torno de $1 \mathrm{~g} / \mathrm{mL}$, o peso final do volume de extração foi levado em conta para os cálculos de concentração. Um tampão fosfato $0,1 \mathrm{M} \mathrm{pH} \mathrm{9,0} \mathrm{foi} \mathrm{utilizado} \mathrm{como}$ solvente de extração. A temperatura e pressão de extração foram $40^{\circ} \mathrm{C}$ e $10 \mathrm{MPa}$, respectivamente. Cada etapa de extração compreendeu três ciclos de 3 min de tempo estático. Após cada ciclo, a célula foi lavada com novo solvente de extração ( $20 \%$ do volume da célula de extração). Finalmente, após o terceiro tempo estático, foi feita a purga da célula de extração com um fluxo de nitrogênio (10 MPa por $60 \mathrm{~s}$ ). O tempo total de extração levou $15 \mathrm{~min}$. A mesma amostra foi re-extraída 2 vezes. Cada extrato (aproximadamente $30 \mathrm{~mL}$ ) foi recuperado em diferentes frascos e filtrados com membrana PVDF hidrofílica 0,22 $\mu \mathrm{m}$ (Millipore, Carrigtwohill, Irlanda) antes da análise cromatográfica. As extrações foram realizadas em triplicata para cada amostra individual de farinha de trigo. 


\subsection{Cromatografia Líquida de Alta Eficiência (HPLC)}

As separações cromatográficas foram realizadas da mesma maneira como descrito no Método 5 do item 1.4 do Capítulo 3.

\subsubsection{Análise Quantitativa de AF em farinhas de trigo fortificadas}

A quantificação do AF foi realizada por padronização externa com solução padrão de AF. Para esta, uma solução padrão de AF $(1000 \mu \mathrm{g} / \mathrm{mL})$ foi inicialmente preparada com tampão fosfato $0,1 \mathrm{M} \mathrm{pH} \mathrm{9,0} \mathrm{e} \mathrm{então} \mathrm{diluída} \mathrm{para}$ obter uma solução de concentração final de $2 \mu \mathrm{g} / \mathrm{mL}$. Esta última foi utilizada para preparar curva de calibração com seis diferentes pontos, na faixa de 0,02 a $0,3 \mu \mathrm{g} / \mathrm{mL}$. Todas as soluções de calibração padrão foram preparadas sob o abrigo da luz e armazenadas em frascos âmbar para proteger o AF da degradação oxidativa da luz.

As amostras de farinha de trigo e de pão foram analisadas em triplicata. As concentrações de AF foram expressas em $\mu \mathrm{g} / \mathrm{g}$ de farinha de trigo. Os resultados foram expressos como média \pm desvio padrão (DP). Para a comparação das médias aritméticas, empregou-se o teste ANOVA e o teste de Tukey usando o software Statgraphics Plus para Windows. Adotou-se o nível de significância de $5 \%$ de probabilidade $(p<0,05)$. 


\section{RESULTADOS E DISCUSSÃO}

\subsection{Efeito do processamento por Radiação lonizante em amostras} de AF em pó e em amostras de farinhas de trigo fortificadas com AF

Tendo em vista que o processo de fortificação de farinhas envolveu a adição do AF em pó, foi estudado inicialmente o efeito do processamento por radiação na própria vitamina em sua forma sólida.

Logo após a irradiação, o AF em pó foi dissolvido em água com adição de $\mathrm{NaOH}$ a uma concentração final de $0,1 \mathrm{mg} / \mathrm{mL}$ ( $\mathrm{pH}$ 12) e quantificado por HPLC (como descrito no Capítulo 1). Foi observada que a concentração do AF se manteve constante em toda a faixa de doses de radiação utilizada $(1,0$ a $10,0$ kGy) ( $p \geq 0,05)$.

Salvo raras exceções, a água é constituinte majoritário dos alimentos; mesmo alimentos ditos secos, tais como farinha de trigo ou vegetais desidratados, contem quantidades consideráveis de água.

Mesmo o AF disponível comercialmente (em pó) contem em média de 8,0 a 8,5\% de hidratação (Temple et al., 1984). Entretanto, o teor de umidade de $8 \%$ não provocou uma radiosensibilidade no AF em pó. Como visto anteriormente no capítulo 2, o AF solubilizado é extremamente radiosensível, com uma perda de $50 \%$ com doses de radiação inferiores a 1 kGy. Por outro lado, o AF em pó não é sensível ao tratamento por radiação com doses de até 10 kGy.

As amostras de farinha de trigo fortificadas não-irradiadas e irradiadas em toda a faixa de doses de radiação testadas também não apresentaram diferença significativa em relação ao teor de $\mathrm{AF}$ antes e depois do processamento por radiação ( $\mathrm{p} \geq 0,05)$ (FIG. 50). 


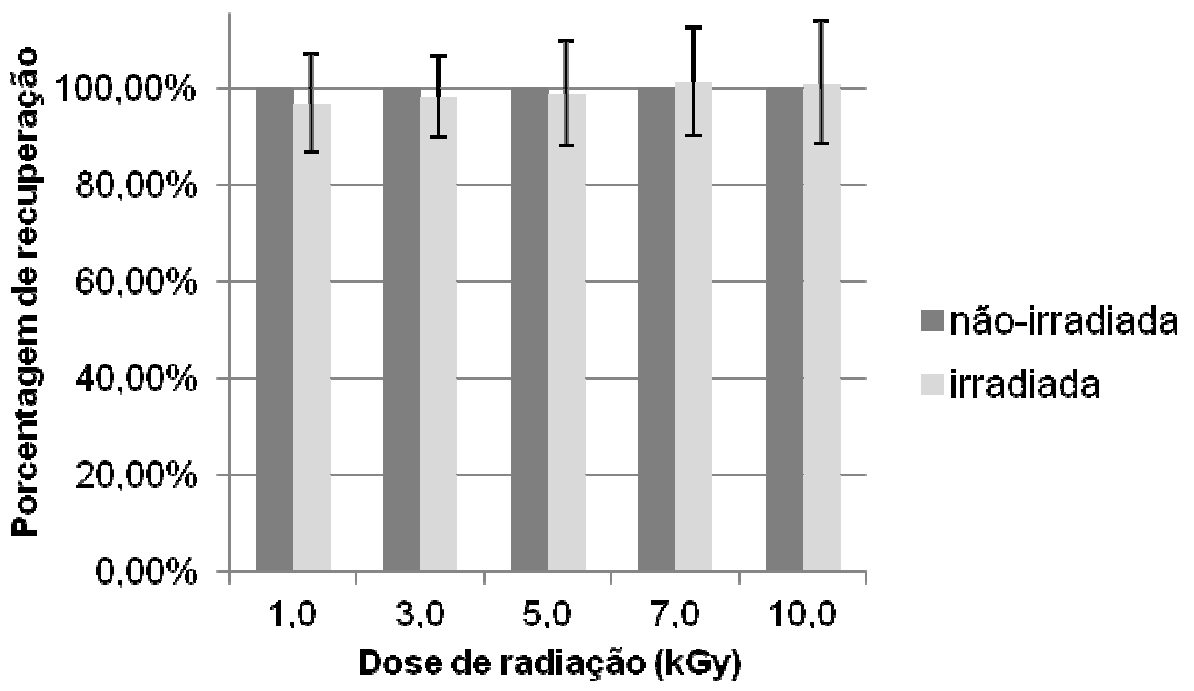

FIGURA 50 - Porcentagem de recuperação do AF de amostras de farinhas de trigo processadas por feixe de elétrons.

O conteúdo de água de amostras de farinha de trigo também foi determinado, sendo em torno de $13 \%(\mathrm{~m} / \mathrm{m})$. Este resultado é consistente com dados da literatura e depende do tipo de farinha de trigo (Souci, 2008). Não obstante, o nível de hidratação das amostras de farinha de trigo não alterou a radiosensibilidade do AF e seu teor nas amostras após o processamento por radiação manteve constante.

Müller et al. (1996) observaram que a estabilidade dos folatos ao processamento por radiação tem relação direta com o teor de umidade dos alimentos. Amostras frescas de espinafre, couve e couve-de-Bruxelas irradiadas com doses de 2,5; 5,0 e 10,0 kGy apresentaram uma perda mais acentuada de folatos que as mesmas amostras desidratadas.

Galán et al. (2010), estudaram os efeitos do tratamento com feixe de elétrons em hambúrgueres enriquecidos com AF e encontraram de 20 a $30 \%$ de redução do conteúdo de $A F$ logo de irradiação com uma dose de $2 \mathrm{kGy}$. Este fato pode ser facilmente explicado pela elevada quantidade de água presente em hambúrgueres, o que não é o caso das amostras de farinha de trigo. 
É evidente que a destruição sofrida por materiais secos como resultado da irradiação é muito menor que naqueles materiais com teor de água mais elevado, onde os efeitos indiretos da radiação são predominantes.

O principal interesse da irradiação de grãos, cereais e farinhas é a desinfestação. Neste sentido, as doses requeridas são da ordem de 1 kGy ou inferiores (Who, 1994; Hayashi et al., 1998). Assim, podemos concluir que o processamento por radiação ionizante pode ser aplicado em cereais fortificados como medida fitossanitária, sem comprometer o nível de fortificação do produto estabelecido por lei.

\subsection{Quantificação do AF em Pães Fabricados com Farinha de Trigo}

\section{Fortificada Irradiada}

Neste estudo, foi utilizada uma máquina de pão para a fabricação automatizada dos pães. Isto permitiu automatizar todas as etapas do processo (mistura, fermentação e cocção), minimizando erros de manipulação.

Geralmente, a cocção de pães é feita em fornos com uma temperatura média de $200^{\circ} \mathrm{C}$ durante 25-27 min (Calvel, 1987). Na máquina de pão utilizada, a temperatura máxima foi de $135^{\circ} \mathrm{C}$ na lateral da cuba de mistura e cocção e de $98^{\complement} \mathrm{C}$ no interior do pão. Entretanto, o tempo de coc ção mais longo (48 min) foi utilizado.

O uso da moagem criogênica de fatias dos pães permitiu a obtenção de um pó fino e homogêneo. As fatias de pão não apresentaram uma variação de peso antes e depois do processo de criomoagem.

O conteúdo de AF nos pães foi calculado como a porcentagem de recuperação do $A F$ baseado na concentração inicial presente na farinha de trigo fortificada. Esta porcentagem de recuperação foi utillizada para avaliar a degradação do AF antes e depois da fabricação do pão. Antes da fabricação, o conteúdo de AF na farinha de trigo fortificada foi normalizado a $100 \%$ e os valores de porcentagem de recuperação foram baseados nesta concentração inicial.

Observou-se que o processo de fabricação do pão promoveu uma degradação no conteúdo do AF inicial $(p<0,05)$. As amostras de pão apresentaram um queda acentuada no teor de $A F$, representando uma perda de entre $24 \%$ (amostra de pão preparada com farinha de trigo irradiada com dose de 
1 kGy) e 57\% (amostra de pão preparada com farinha de trigo irradiada com dose de 5 kGy) (FIG. 51).

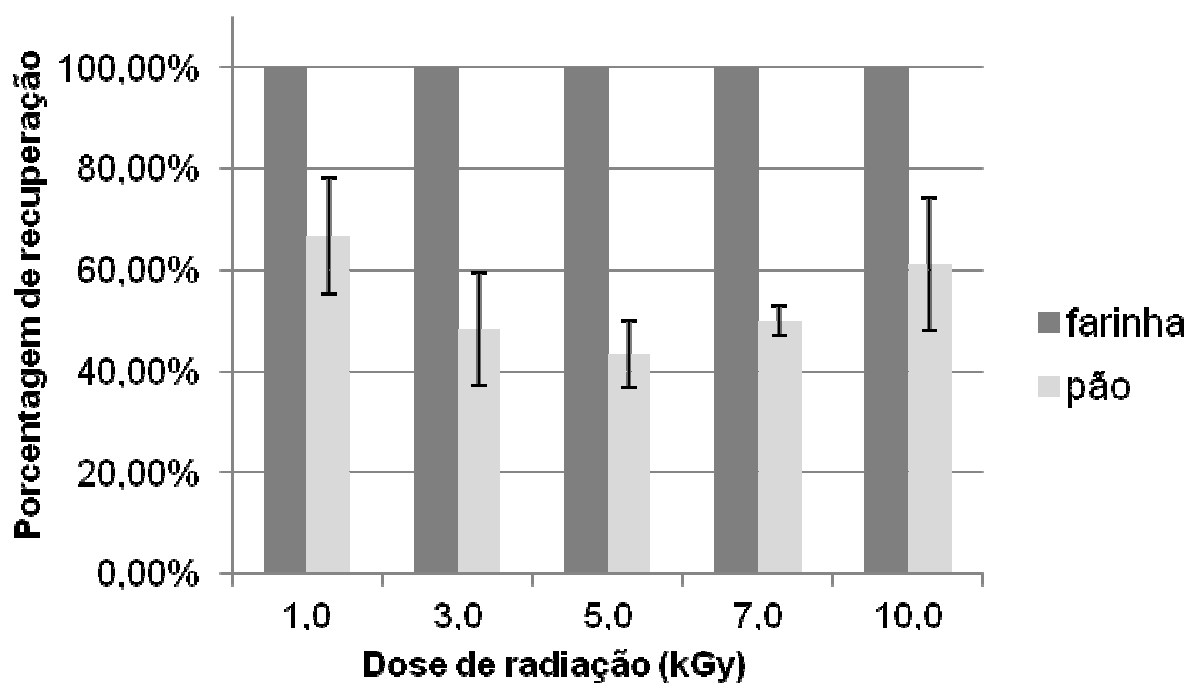

FIGURA 51 - Porcentagem de recuperação do AF de amostras de farinhas de trigo irradiadas e pães preparados com farinha de trigo irradiada.

A fim de verificar se a diminuição do teor de AF nas amostras de pão preparadas com farinha de trigo fortificada não foi decorrente de uma ESP incompleta do pão, a ESL foi utilizada como método de comparação. Os resultados obtidos por ESP e ESL corroboraram a queda significativa do teor de AF nas amostras de pão, sendo os dois métodos consistentes (FIG. 52). Assim, a ESP poderia ser igualmente aplicada para a extração de AF de amostras de pão preparados com farinha de trigo fortificada. 


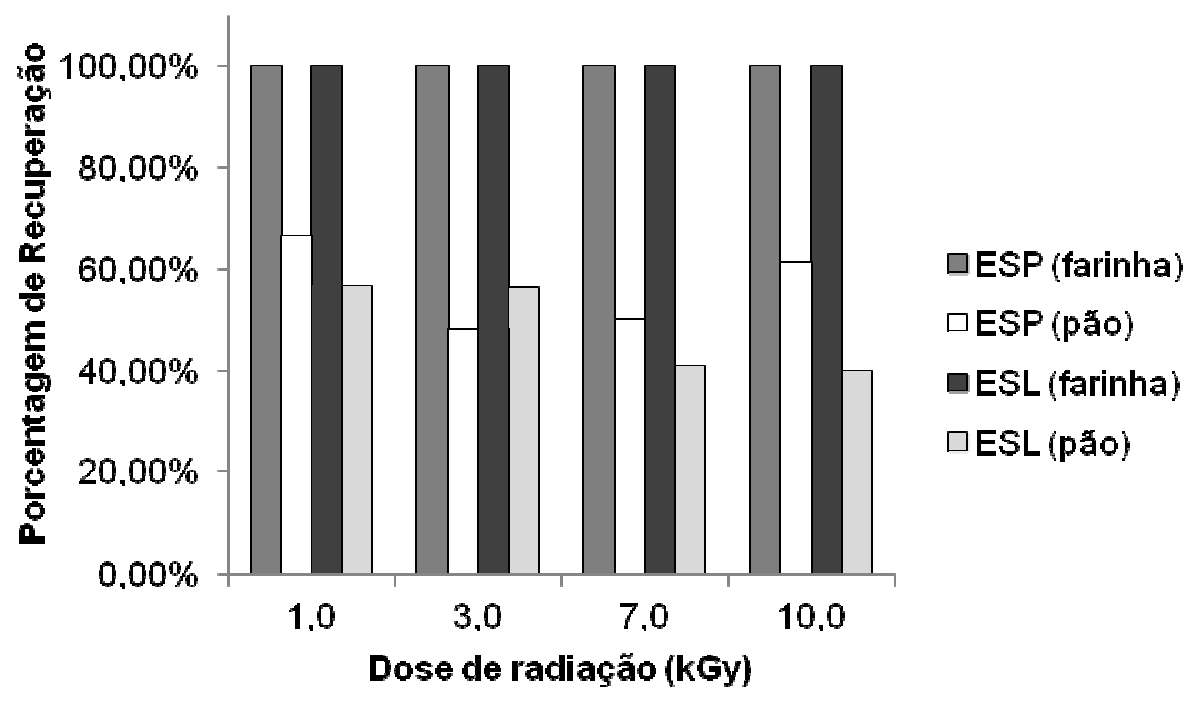

FIGURA 52. Comparação dos resultados de porcentagem de recuperação do AF de amostras de farinha de trigo fortificada e de pão preparado com farinha de trigo fortificada.

No capítulo 2, foi mostrado o alto poder de degradação do aquecimento a $200^{\circ} \mathrm{C}$ na molécula de $\mathrm{AF}$ em pó. A fim de compreender a influência da temperatura de cocção neste experimento em particular, amostras de AF em pó foram aquecidas dentro da cuba da máquina de pão. Para isso, quantidades precisas de AF acondicionadas em recipientes de vidro foram aquecidas por igual período de tempo (48 min) à cocção do pão propriamente dita. Após o aquecimento, a amostra foi resfriada, solubilizada em água com adição de $\mathrm{NaOH}$ $(0,1 \mathrm{mg} / \mathrm{mL}, \mathrm{pH} 12)$ e analisada por HPLC, como ilustra o perfil cromatográfico na FIG. 53.

Notou-se que o aquecimento do $\mathrm{AF}$ na cuba da máquina de pão ocasionou uma ligeira degradação transcorridos os 48 min de tratamento térmico (FIG. 53). Foi encontrado um produto de degradação majoritário com tempo de retenção de 18,5 min. A suspeita de que este pico cromatográfico se tratasse do pABGA foi confirmada com a injeção de uma solução padrão deste composto $(10 \mu \mathrm{g} / \mathrm{mL})$. Esta hipótese foi confirmada pela coerência de tr e espectro UV deste produto de degradação e da solução padrão de pABGA. 


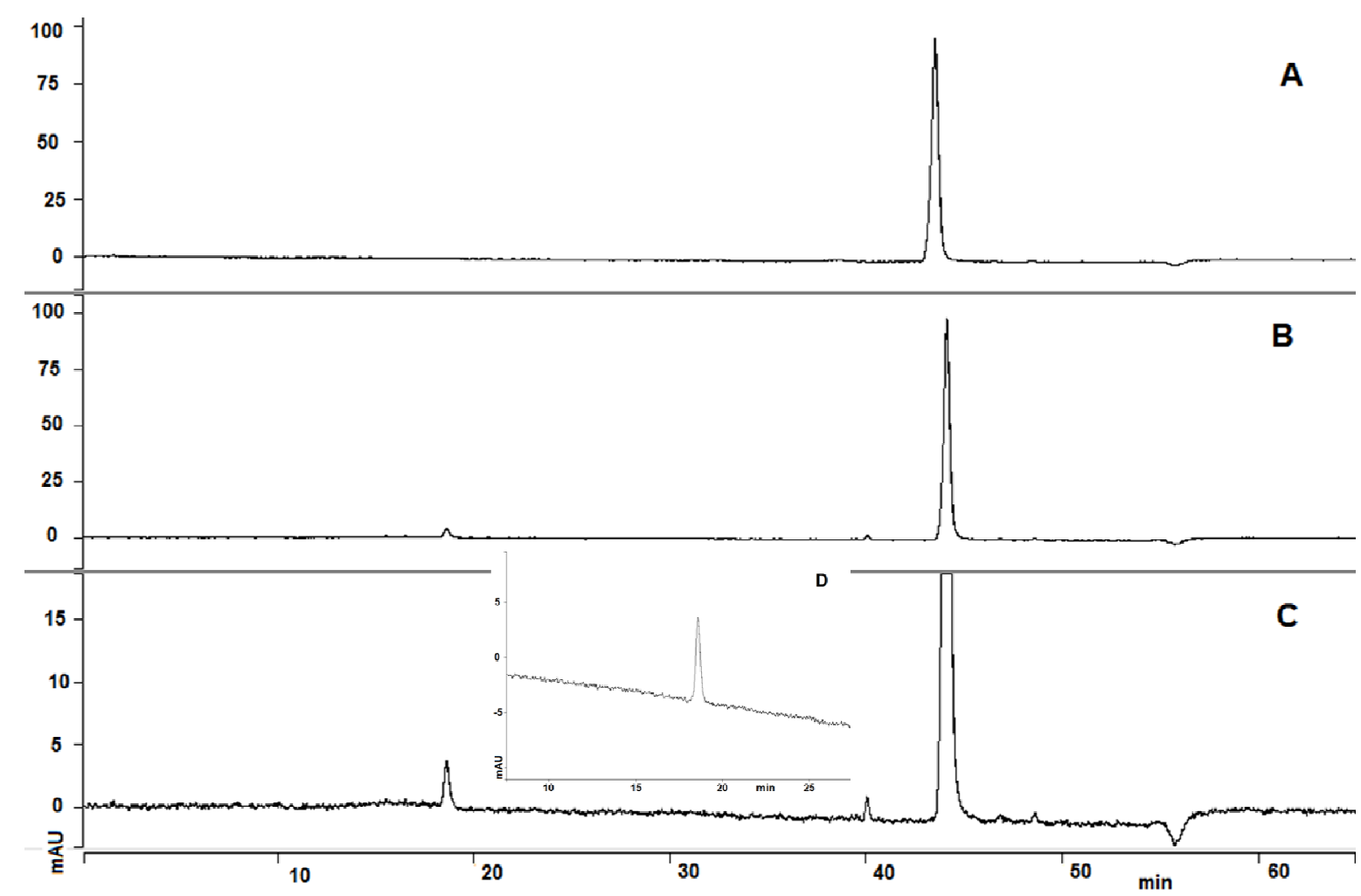

FIGURA 53 - Efeito do aquecimento do AF em pó dentro da cuba da máquina de pão: $A F$ controle (A); $A F$ aquecido por 48 min (B); zoom do cromatrograma $B(C)$; zoom de cromatograma de pABGA (D).

Vale ressaltar que diferentemente deste ensaio, na fabricação de pão há uma quantidade considerável de água, o que pode potencializar ainda mais o processo de ruptura da molécula de AF. Uma degradação deste tipo pode ter ocorrido durante o processo de fabricação do pão o que explicaria a perda acentuada de AF durante o processo. Assim, associada à perda de AF durante a fabricação de pão haveria a formação de pABGA, um produto de degradação sem atividade vitamínica.

Os resultados encontrados em relação à perda do AF durante o processo de fabricação de pão vão ao encontro com outros trabalhos. Gujska et al. (2005) também notaram um decaimento do AF em pães preparados com 
farinha de trigo e farinha de centeio fortificadas. Eles apontaram que as perdas variaram de 12 a $21 \%$, dependendo do processo de panificação empregado. De maneira similar, Anderson et al. (2010) também verificaram uma degradação térmica do AF durante a etapa de cocção do pão, com uma perda de entre $21,9 \%$ e $32,1 \%$.

Tendo em vista que a irradiação não alterou o conteúdo do AF presente em farinhas de trigo fortificadas, pudemos concluir que não houve um efeito combinado do processamento por irradiação e fabricação do pão. Assim, a perda do conteúdo de AF nas amostras de farinhas de trigo deveu-se exclusivamente à fabricação do pão e em especial à etapa de cocção. 


\section{CONCLUSÕES}

A legislação brasileira estabelece a fortificação compulsória de farinha de trigo e milho com AF. Tão importante que conhecer o conteúdo de AF neste ingrediente alimentício é entender o efeito do processamento de alimentos e fundamentalmente da preparação de alimentos na conservação da vitamina adicionada. Assim, pode-se concluir que:

- a irradiação de amostras de farinha de trigo fortificada não alterou o teor de AF na faixa de dose de radiação de 1,0 a 10,0 kGy;

- o processamento por radiação ionizante poderia ser aplicado em cereais fortificados com AF como medida fitossanitária, não comprometendo o nível de fortificação do produto final;

- a extração por solvente pressurizado foi aplicada com sucesso para a extração de AF em amostras de pães preparados com farinha de trigo fortificada;

- a fabricação de pão promoveu uma redução acentuada no teor de AF do produto final;

- o tratamento térmico do $A F$ em pó nas condições deste ensaio promoveu uma degradação do AF e formação do produto de degradação pABGA, sem atividade vitamínica. 


\section{CONCLUSÕES GERAIS}

Os processamentos por radiação ionizante, aquecimento em estufa $\left(200^{\circ} \mathrm{C}\right)$ e aquecimento em forno micro-ondas promover am uma degradação importante do AF.

No processo degradativo do AF decorrente do processo de irradiação, os parâmetros condição de solubilização, $\mathrm{pH}$ e atmosfera influenciaram sua radiosensibilidade. A degradação do $\mathrm{AF}$ foi proporcional à dose de radiação aplicada e solubilização da amostra.

O processo degradativo do AF decorrente do tratamento térmico em estufa e forno micro-ondas foi proporcional ao tempo do processamento.

Os três tratamentos ocasionaram uma importante ruptura da molécula de $A F$ e formação de produtos de degradação majoritários, a saber: PCA, PABA, PABGA e PA.

A irradiação com feixe elétrons de uma solução de $A F$ promoveu o aparecimento de três novos produtos de degradação: XA, AHMP e pNBGA.

O AF só tem atividade vitamínica na sua forma íntegra, logo os novos produtos de degradação identificados não têm esta atividade biológica.

O conhecimento sobre a degradação do AF decorrente do tratamento de alimentos permite predizer danos que podem ocorrer na molécula, ressaltando a necessidade de constante avaliação dos níveis de fortificação de alimentos para que quantidade suplementada da vitamina seja adequada.

A fortificação de alimentos com AF ressalta a necessidade de métodos de extração e quantificação rápidos e confiáveis. Neste trabalho, o método de extração por solvente pressurizado foi otimizado para a extração completa do AF de amostras de farinha de trigo fortificada em apenas 15 minutos.

A esta redução do tempo de extração soma-se uma redução considerável de volume de solvente utilizado (apenas $30 \mathrm{~mL}$ ) e a economia na compra de consumíveis.

A irradiação de farinha de trigo fortificada com AF não alterou o teor de AF na faixa de dose de radiação de 1,0 a 10,0 kGy. 
O processamento por radiação ionizante poderia ser aplicado em cereais fortificados com AF como medida fitossanitária, não comprometendo o nível de fortificação do produto final.

A extração por solvente pressurizado foi aplicada com sucesso para a extração de AF em amostras de pães preparados com farinha de trigo fortificada.

O processo de fabricação de pão promoveu uma redução acentuada no teor de AF do produto final e formação do produto de degradação pABGA, sem atividade vitamínica. 


AGRICULLTURAL' AN AND
FOOD CHEMISTRY

\section{Irradiation Stability of Folic Acid in Powder and Aqueous Solution}

Michel M. Araújo, ${ }^{\dagger}$ Eric Marchioni, ${ }^{, \dagger}$ Martine Bergaentzle, ${ }^{\dagger}$ Minjie Zhao, ${ }^{,}$Florent Kuntz, ${ }^{\S}$ Emeline Hahn, ${ }^{,}$and Anna Lucia C. H. Villavicencio ${ }^{+}$

${ }^{\dagger}$ Instituto de Pesquisas Energéticas e Nucleares (IPEN-CNEN/SP), Centro de Tecnologia das Radiações, Av. Prof. Lineu Prestes, 2242, 05508-910, São Paulo, Brazil

${ }^{\ddagger}$ Equipe de Chimie Analytique des Molécules Bioactives (IPHC-LC4, UMR 7178), Université de Strasbourg, Faculté de Pharmacie, 74 route du Rhin, 67400 Illkirch, France

${ }^{5}$ Aérial, Centre de Ressources Technologiques, Parc d’Innovation, rue Laurent Fries, B.P. 40443, F-67412 Illkirch, France

ABSTRACT: This study attempts to examine the folic acid stability after irradiation treatment, under different physical states, $\mathrm{pH}$ values, and atmosphere conditions. Aqueous folic acid samples, folic acid in powder, and wheat flour fortified with folic acid were irradiated by an electron beam (E-beam) between 0 (control) and $10.0 \mathrm{kGy}$. It was realized that the physical state of folic acid plays an important role on its stability toward E-beam processing, being largely unstable in solution, no matter the $\mathrm{pH}$ and atmosphere conditions assayed. Otherwise, folic acid in powder showed huge irradiation stability, even when mixed in a dry food matrix, such as fortified wheat flour samples.

KEYWORDS: Radiation processing, folic acid, stability, wheat flour

\section{INTRODUCTION}

Folates are a group of vitamins based on the parent compound folic acid (FA) [pteroylglutamic acid (PGA)]. They belong to the $\mathrm{B}$ vitamin group and are an essential food element in the human diet. FA is a yellowish orange crystalline powder that is tasteless and odorless. It is composed of a pteridine ring, $p$-amino benzoic acid (PABA), and glutamate moieties (Figure 1). Separately, the three moieties have no vitamin activity.

The human metabolism is not able to synthesize folates and, therefore, has to obtain them from the diet. Dietary sources rich in folates include yeast extracts, liver, eggs, kidney, green leafy vegetables, legumes, and citrus fruits. ${ }^{2}$ A deficiency of folate in the diet is closely linked to the presence of neural tube defects in newborns and an increased risk of megaloblastic anemia, cancer, Alzheimer's disease, and cardiovascular disease in adults. ${ }^{3,4}$ This has led to the fortification of some foodstuffs with $\mathrm{FA} .{ }^{5} \mathrm{FA}$, a synthetic vitamer, is used as a food fortificant in cereals and dairy products because of its low price, relative stability, and increased bioavailability compared to natural folate forms. ${ }^{6,7}$ Following other countries, in 2002, the Brazilian Agency for Public Health Surveillance (ANVISA) required the mandatory fortification of wheat and corn flours with FA at a concentration of $1.50 \mu \mathrm{gg}^{-1}$ of flour. ${ }^{8}$

New food product development and food processing aims to retain as much as possible of the naturally occurring vitamin content, to protect added vitamins, and to minimize the appearance of undesirable neo-formed products. ${ }^{9}$ The stability of folates during food processing is influenced by temperature, pressure, $\mathrm{pH}$, oxygen, light, metal ions, antioxidants, and duration of heat$\mathrm{pH}$, oxygen, light, metal ions, antioxidants, and duration of heat-
ing. ${ }^{10-12}$ More and more, industries are using "non-thermal technologies" to treat food products. Among the so-called "nonthermal technologies", food irradiation is a process in which food is exposed to ionizing radiations, such as high energy electrons

ACS Publications 2011 American Chemical society

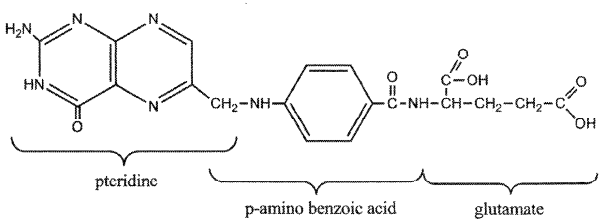

Figure 1. Structural formula of $\mathrm{FA}$ at $\mathrm{pH} 7$

and $\mathrm{X}$-rays produced by electron accelerators [electron beams (E-beams)] or $\gamma$ rays emitted from the radioisotopes ${ }^{60} \mathrm{Co}$ Dependent upon the absorbed radiation dose, various effects can be achieved resulting in reduced storage losses, extended shelf life, and/or improved microbiological and parasitological safety of foods. ${ }^{1.3}$ Food irradiation is one of the most effective means to disinfect dry food ingredients. Disinfestation is aimed at preventing losses caused by insects in stored grains, pulses, flour, cereals, coffee beans, dried fruits, dried nuts, and other food products. ${ }^{14}$ The dosage required for insect control is fairly low, of products.
the order of $1 \mathrm{kGy}$ or less. ${ }^{15}$ In comparison to $\gamma$ ray installations, E-beam facilities do not need reloading and can be streamlined to food processing, reducing logistic costs. ${ }^{16}$ Safety and efficiency of food irradiation has been proven by several authorities [Food and Drug Administration (FDA), United States Department of Agriculture (USDA), World Health Organization (WHO), Food and Agriculture Organization (FAO), etc.] and scientific societies based on extensive research. ${ }^{17}$,
Received: October 12, 2010
Accepted: December 23, 2010
Revised: December 19, 2010

Published: January 28, 2011 
Previous authors have already studied the effect of radiation processing in natural folates and FA in foods ${ }^{19,20}$ and the thermal/photostability of the synthetic folate form, FA. ${ }^{21-23}$ The novelty of this work was to examine the effect of irradiation on the stability of FA under different moisture contents, atmosphere conditions, and $\mathrm{pH}$ values. Indeed, because FA is unstable under acid medium, alkaline and neutral $\mathrm{pH}$ values were analyzed. A neutral solution of FA was allowed by the addition of ammonium acetate to water FA suspensions. The irradiation effect was analyzed on not only the synthetic vitamer itself but also the FA-fortified wheat flour.

\section{MATERIALS AND METHODS}

Materials. Chemicals. Methanol ( $\mathrm{MeOH})$ (Carlo Erba, Val de Reuil, France) and acetonitrile (ACN) (Sigma-Aldrich, Steinheim, Germany) were high-performance liquid chromatography (HPLC)grade. Methanol for Karl Fisher determination (Carlo Erba, Val de Reuil, France) was European-Pharmacopeia-grade. All other chemicals were of analytical grade. Formic acid was purchased from Riedel-de Haen (Seelze, Germany). Sodium hydroxide $(\mathrm{NaOH})$ was purchased from SDS (Peypin, France). Ammonium acetate, dibasic sodium phosphate, and monobasic potassium phosphate were purchased from Merck (Darmstadt, Germany). FA was obtained from Sigma-Aldrich Merck (Darmstadt, Germany). FA was obtained from Sigma-Aldrich
(Steinheim, Germany). Water was purified using a Synergy Milli-Q System (Millipore, Molsheim, France).

Samples. FA. All FA aqueous solutions and suspensions were prepared under subdued light, to protect folates from oxidative degradation induced by light. To assess both the $\mathrm{pH}$-dependent response and solubilization effect, FA in powder, solutions, and suspensions were prepared under four different conditions: (a) A total of $100 \mathrm{mg}$ of FA was added to $100 \mathrm{~mL}$ of water and solubilized by the addition of $5.0 \mathrm{~mL}$ of $1 \mathrm{M} \mathrm{NaOH}$. The solution was diluted in water to a final concentration of $1 \mathrm{M} \mathrm{NaOH}$. The solution was diluted in water to a final concentration
of $0.1 \mathrm{mg} / \mathrm{mL}$, resulting in a $\mathrm{pH}$ of 12 . (b) A total of $100 \mathrm{mg}$ of FA was added to $100 \mathrm{~mL}$ of water and solubilized by the addition of $0.5 \mathrm{~mL}$ of $1 \mathrm{M} \mathrm{NaOH}$. The solution was diluted in water to a final concentration of $0.1 \mathrm{mg} / \mathrm{mL}$, resulting in a pH of 8 . (c) A total of $100 \mathrm{mg}$ of FA was added to $1000 \mathrm{~mL}$ of water and solubilized by the addition of $100 \mathrm{~mL}$ of $0.4 \mathrm{M}$ ammonium acetate, resulting in a final concentration of $0.1 \mathrm{mg} / \mathrm{mL}$ at a $\mathrm{pH}$ of 6.8. (d) A total of $70 \mathrm{mg} F A$ was added to $700 \mathrm{~mL}$ of water, resulting in a final concentration of $0.1 \mathrm{mg} / \mathrm{mL}$ (suspension). (e) FA was in powder.

Prior to irradiation, a set of samples were sealed in the presence of oxygen and another set of samples were sealed in the presence of nitrogen (obtained by flushing the air gap with pure nitrogen gas for $1 \mathrm{~min}$ ).

All samples ( $4 \mathrm{~mm}$ thick) were packed in plastic sachets, sealed, and labeled with their respective radiation doses.

Folate solutions were directly injected to the chromatographic system. Folate suspensions were first solubilized by the addition of $1 \mathrm{M} \mathrm{NaOH}(5 \mu \mathrm{L}$ to each $1 \mathrm{~mL}$ of $0.1 \mathrm{mg} / \mathrm{mL} \mathrm{FA})$, prior to injection. FA in powder was first added to water at $1 \mathrm{mg} / \mathrm{mL}$ and solubilized by the addition of $1 \mathrm{MNaOH}(50 \mu \mathrm{L}$ to each $1 \mathrm{~mL}$ of $1 \mathrm{mg} / \mathrm{mL}$ solution). Prior to injection, this solution was diluted in water to a final concentration of $0.1 \mathrm{mg} / \mathrm{mL}$.

Wheat Flour Fortified with FA. Brazilian wheat flour fortified with FA were purchased in different local supermarkets in São Paulo (Brazil) in July 2010 (positive control). Non-fortified wheat flours were purchased in local supermarkets in Strasbourg (France) in July 2010 and fortified in house with FA at a final concentration of $1.50 \mu \mathrm{g} \mathrm{g}^{-1}$. Blending was carried out with a Turbula T2F shaker (Wab, Basel, Switzerland) at a speed of $72 \mathrm{rpm}$ and a fill volume of approximately $25 \%$. First, $45 \mathrm{mg}$ of FA was blended with $300 \mathrm{~g}$ of wheat flour for $2 \mathrm{~min}$, resulting in a final concentration of $150 \mu \mathrm{g} \mathrm{g}^{-1}$. Second, $30 \mathrm{~g}(150 \mu \mathrm{g}$ $\mathrm{g}^{-1}$ mixture) was blended with $270 \mathrm{~g}$ of wheat flour for $5 \mathrm{~min}$, resulting in a final concentration of $15 \mu \mathrm{g} \mathrm{g}^{-1}$. Finally, $3 \mathrm{~g}\left(15 \mu \mathrm{g} \mathrm{g}^{-1}\right.$ mixture $)$ was blended with $297 \mathrm{~g}$ of wheat flour for $10 \mathrm{~min}$, resulting in a final concentration of $1.5 \mu \mathrm{g} \mathrm{g}^{-1}$

A total of $20 \mathrm{~g}$ of samples ( $4 \mathrm{~mm}$ thick) were packed in plastic sachets, A total of $20 \mathrm{~g}$ of samples $(4 \mathrm{~mm}$ thick) were packed in $\mathrm{p}$
sealed, and labeled with their respective radiation doses.

Methods. Irradiation Treatment. FA powder samples were irradiated with a Rhodotron E-beam accelerator (IBA, Louvain la Neuve, Belgique), with a $15 \mathrm{~mA}$ current, $160 \mathrm{~cm}$ scan width, and $10 \mathrm{MeV}$ energy. Applied doses (maximum of $\pm 10 \%$ ) were 0 (control), 1.0, 3.0, 5.0, 7.0, and $10.0 \mathrm{kGy}$.

FA aqueous solutions and suspensions and wheat flours fortified with FA were irradiated with a Van de Graaff E-beam accelerator, $2 \mathrm{MeV}$ (Vivirad High Voltage, Handschuheim, France) with a $100 \mu \mathrm{A}$ current, $20 \mathrm{~cm}$ scan width, and about $2 \mathrm{kGy} / \mathrm{s}$ dose rate. Applied doses were 0 (control), $0.3,0.54,0.79,1.0,3.4,5.3,7.5$, and $10.7 \mathrm{kGy}$. Surfaceabsorbed doses were monitored with FWT 60.00 radiochromic dosimeters ( uniformity of about $10 \%$ within the sample was achieved by the use of a $100 \mu \mathrm{m}$ thick copper scattering foil. ${ }^{25}$ For both irradiation plants, standard conditions for temperature and pressure were used $\left(25^{\circ} \mathrm{C}\right.$ and $\left.1 \mathrm{~atm}\right)$.

Extraction. A total of $2 \mathrm{~g}$ of wheat flour sample was extracted once with $10 \mathrm{~mL}$ of extraction phosphate buffer at pH $6.3\left(0.25 \mathrm{M} \mathrm{Na}_{2} \mathrm{HPO}_{4}\right.$ and $0.37 \mathrm{M} \mathrm{KH}_{2} \mathrm{PO}_{4}$ ), adapted from Alaburda et al. ${ }^{26}$ The mixture was shaken for $30 \mathrm{~min}$ in a rotational shaker and centrifuged at $3500 \mathrm{rpm}$ for $15 \mathrm{~min}$. The supernatant was filtered through a $0.45 \mu \mathrm{m}$ hydrophilic polyvinylidene fluoride (PVDF) membrane (Millipore, Carrigtwohill, Ireland) before chromatography analysis.

HPLC. Experimental work was performed using a Varian ProStar HPLC system (Palo Alto, CA) [9012 binary HPLC pump, 9300 injector, and 330 diode array detection (DAD) UV-vis detector] Chromatographic separation was carried out on a Hypersil Gold aQ C18 analytical column $(4.6 \times 250 \mathrm{~mm} ; 5 \mu \mathrm{m}$ particle size) (Thermo Scientific), column $(4.6 \times 250 \mathrm{~mm} ; 5 \mu \mathrm{m}$ particle size) (Thermo Scien
protected by an ODS precolumn (Uniguard, Thermo Scientific).

protected by an ODS precolumn (Uniguard, Thermo Scientific).
For FA preparations (100 ppm), the mobile phase consisted of aqueous formic acid ( $\mathrm{pH} 3.5$ ) and methanol, at a flow rate of $1.0 \mathrm{~mL} /$ min. Gradient elution started at 5\% $\mathrm{MeOH}$ maintained for $10 \mathrm{~min}$, followed by raising the $\mathrm{MeOH}$ concentration linearly to $50 \%$ within $20 \mathrm{~min}$. Subsequently, the $\mathrm{MeOH}$ concentration decreased again to $5 \%$ in $1 \mathrm{~min}$, and the column was equilibrated for $14 \mathrm{~min}$ with the initial mixture. An injection volume of $20 \mu \mathrm{L}$ was used.

For wheat flour preparations $(1.5 \mathrm{ppm})$, a gradient elution with acetonitrile and aqueous acetic acid $(\mathrm{pH} 2.8)$ was used ${ }^{26}$ to obtain a better chromatographic resolution and a subsequently higher sensitivity of detection. The flow rate was $0.7 \mathrm{~mL} / \mathrm{min}$. The gradient started at $8 \%$ $\mathrm{ACN}$, and after $10 \mathrm{~min}$, the $\mathrm{ACN}$ proportion was linearly raised to $26 \%$ within $1 \mathrm{~min}$. It was isocratically maintained for $5 \mathrm{~min}$. Thereafter, the $\mathrm{ACN}$ concentration was linearly raised to $50 \%$ within 6 min and isocratically maintained for $9 \mathrm{~min}$. The ACN proportion came back to $8 \%$ within $5 \mathrm{~min}$, and the column was restabilized for $10 \mathrm{~min}$ before the next injection. An injection volume of $20 \mu \mathrm{L}$ was used.

Both detections were performed at $280 \mathrm{~nm}$. To control the analytical system, a negative control $\left(\mathrm{H}_{2} \mathrm{O}\right)$ and a positive control $(0.1 \mathrm{mg} / \mathrm{mL}$ FA aqueous solution at $\mathrm{pH} 12$ ) were injected throughout the sample analysis every 10 injections. FA identity was controlled by its UV spectra (DAD).

Karl Fischer Titration. Titration was performed using a TitroMatic Karl Fischer Titration. Titration was performed using a TitroMatic
KF 1S-2B titrator (Crison, Barcelona, Spain). A total of $2 \mathrm{~g}$ of wheat flour was added to methanol (final volume of $50 \mathrm{~mL}$ ) and agitated for $15 \mathrm{~min}$ at $50^{\circ} \mathrm{C}$. After cooling to room temperature and sedimentation, the supernatant $(3 \mathrm{~mL})$ was used for titration for $5 \mathrm{~min}$. The blank sample was made of pure methanol.

Statistical Analysis. Data were compared by analysis of variation

Statistical Analysis. Data were compared by analysis of variation
(ANOVA) and Tukey's test (at a significance level of 95\%) using Statgraphics Plus software. All samples were analyzed in triplicate. 


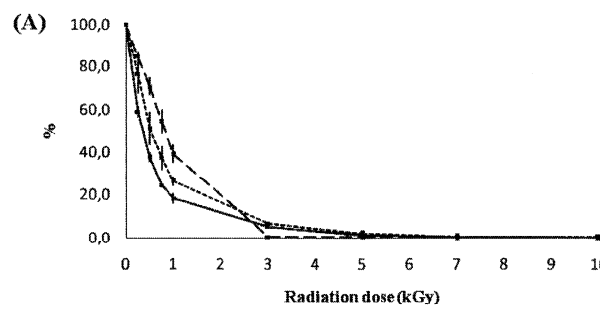

(B) 100,0

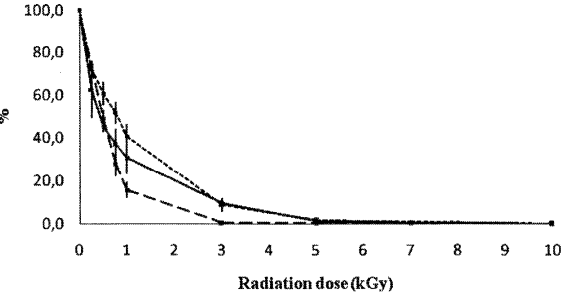

Figure 2. Recovery percentage of $\mathrm{FA}$ in aqueous solution under different $\mathrm{pH}$ values with (A) $\mathrm{O}_{2}$ and (B) $\mathrm{N}_{2}(-, \mathrm{pH} 12 ; \cdots, \mathrm{pH} 8$; $-\cdots, \mathrm{pH} 6.8$ ).

\section{RESULTS AND DISCUSSION}

Irradiation Effect on FA Solutions. All of the FA aqueous solutions showed a decreasing relationship between their concentration and the absorbed radiation doses (Figure 2). The effects of irradiation on water are extremely important, and they have already been extensively discussed in the literature. Water forms a number of radiolytic products, e.g., hydroxyl radicals $(\cdot \mathrm{OH})$, hydrated electrons $\left(\mathrm{e}^{-} \mathrm{H}_{2} \mathrm{O}\right.$ or $\left.\mathrm{e}^{-} \mathrm{aq}\right)$, hydrogen atoms $(\cdot \mathrm{H})$, hydrogen molecules $\left(\mathrm{H}_{2}\right)$, hydrogen peroxide $\left(\mathrm{H}_{2} \mathrm{O}_{2}\right)$, and hydrated protons $\left(\mathrm{H}_{3} \mathrm{O}^{+}\right)$, each of which may react with compounds and food components. ${ }^{14}$ The hydroxyl radical is a powerful oxidizing agent, while the hydrated electron is a strong reducing agent. As a result, both oxidation and reduction reactions take place when compounds and/or foods containing water are irradiated. ${ }^{14,27}$ To assess the irradiation effect in these solutions, similar to toxicological and radiological studies, a proposed $D_{50}$, the half maximal degradation dose, was calculated for each condition assayed. This value intends to represent the radiation dose required for a $50 \%$ degradation of FA. FA aqueous solutions showed a marked degradation even at doses below $1 \mathrm{kGy}$ (Figure 2). There is an expressive reduction in the FA percentage, regardless of the $\mathrm{pH}$ and/or atmosphere conditions assayed. For FA aqueous solutions at $\mathrm{pH} 12, D_{\mathrm{so}}$ values of 0.37 and $0.5 \mathrm{kGy}$ were found with $\mathrm{O}_{2}$ and $\mathrm{N}_{2}$, respectively (Table 1). Nearby $D_{50}$ values $(0.53$ and $0.75 \mathrm{kGy})$ were found for FA aqueous solutions irradiated at $\mathrm{pH} 8$ in the presence of $\mathrm{O}_{2}$ and $\mathrm{N}_{2}$, respectively (Table 1). For each radiation dose applied $(0.25-10 \mathrm{kGy})$, no statistical differences were found between FA aqueous solutions at $\mathrm{pH} 12$ (with $\mathrm{O}_{2}$ and $\left.\mathrm{N}_{2}\right)$ as well as between FA aqueous solutions at $\mathrm{pH} 8\left(\right.$ with $\mathrm{O}_{2}$ and $\left.\mathrm{N}_{2}\right)(p>$ 0.05 ) (Figure 2). The absence of the difference between solutions with $\mathrm{O}_{2}$ and $\mathrm{N}_{2}$ could be explained because, in equilibrium with air, water contains small amounts of dissolved oxygen, which can be reduced by hydrogen atoms to the hydroperoxy radical
Table 1. $D_{50}$ Values (kGy) of FA Aqueous Solutions at $\mathrm{pH}$ $6.8,8.0$, and 12.0 with $\mathrm{O}_{2}$ and $\mathrm{N}_{2}$

\begin{tabular}{cccc} 
& \multicolumn{3}{c}{$\mathrm{pH}$} \\
\cline { 2 - 4 } $\mathrm{O}_{2}$ & 6.8 & 8.0 & 12.0 \\
$\mathrm{~N}_{2}$ & 0.80 & 0.53 & 0.37 \\
\hline
\end{tabular}

$\left(\cdot \mathrm{HO}_{2}\right)$, a mild oxidizing agent. The hydroperoxy radical is in equilibrium with the superoxide radical $\left(\cdot \mathrm{O}_{2}{ }^{-}\right)$, and both of them can produce hydrogen peroxide in a reaction that consumes oxygen; therefore, an anaerobic matrix may be produced by electron irradiation at dose rates as high as such encountered during E-beam processing. ${ }^{14}$ Contrary to these results, Thomas et al., ${ }^{29}$ showed that FA in acid aqueous solutions is photostable in the absence of oxygen when compared to the same samples in the presence of oxygen. On the other hand, for FA aqueous solutions at $\mathrm{pH} 6.8, D_{50}$ values were 0.8 and $0.42 \mathrm{kGy}$ with $\mathrm{O}_{2}$ and $\mathrm{N}_{2}$, respectively (Table 1 ). For these samples, the atmosphere condition $\left(\mathrm{O}_{2}\right.$ or $\left.\mathrm{N}_{2}\right)$ showed a significant difference among $0.5,0.75$, and $1 \mathrm{kGy}$ irradiated samples $(p<0.05)$. With doses higher than $5 \mathrm{kGy}$, for all solutions, a complete FA degradation was reached $(p>0.05)$. Previous authors who studied the irradiation effect in FA stability did not perform studied the irradiation effect in FA stability did not perform studied the effect of FA photolysis under different $\mathrm{pH}$ values. Akhtar et al..$^{22}$ proposed that the photolysis rate of FA gradually decreased upon moving from acid to alkaline $\mathrm{pH}$ values. However, from our results, samples solubilized in ammonium acetate (pH 6.8) appeared to be as susceptible to irradiation as samples solubilized in $\mathrm{NaOH}$ (pH 8 and 12) (Figure 2). Surprisingly ammonium-acetate-solubilized samples showed an increased radiation effect in the absence of oxygen when compared to the same samples in the presence of oxygen. Indeed, samples solubilized in ammonium acetate $\left(\mathrm{pH} 6.8\right.$, with $\mathrm{O}_{2}$ and $\mathrm{N}_{2}$ ) showed a statistical difference compared to $\mathrm{FA}$ aqueous solutions at $\mathrm{pH} 8$ and 12. Therefore, once solubilized, FA is much more unstable to irradiation treatment compared to photolysis. ${ }^{22,2}$ This fact could be due to the energy involved in E-beam treatment, which is an in-depth treatment and, in comparison to photolysis, is a much more energetic process and has a higher dose rate. It is already known that photolysis degradation products have no folate activity. ${ }^{1,22,23,29}$ It could be expected that irradiation will also yield inactive degradation products. No attempt was made yet to identify the degradation products, and one can consider that a decrease of FA content leads to a decrease of the folate activity of the food. In summary, an important irradiation effect on FA degradation was observed for all of the dose range studied $(0.25-10 \mathrm{kGy})$, no matter the conditions assayed (atmosphere or $\mathrm{pH}$ ) (Figure 2).

Irradiation Effect on FA Suspension, FA in Powder, and Wheat Flour Fortified with FA. The effect of E-beam treatment in a FA suspension was studied. Because FA is practically insoluble in water $(0.01 \mathrm{mg} / \mathrm{mL})$, the work solution of $0.1 \mathrm{mg} /$ $\mathrm{mL}$ of FA resulted in dispersion instead of a solution. FA is only soluble and stable in dilute alkaline solution and dissolves but is unstable in acid medium. ${ }^{9,29}$ Similar to FA in powder, FA in suspension $(0.1 \mathrm{mg} / \mathrm{mL}$ in water) showed no significant difference between non-irradiated and irradiated samples (Figure 3 ). The high stability of FA in suspension to radiation processing remained similar from 0 to $5 \mathrm{kGy}$ even if, in this case, an 


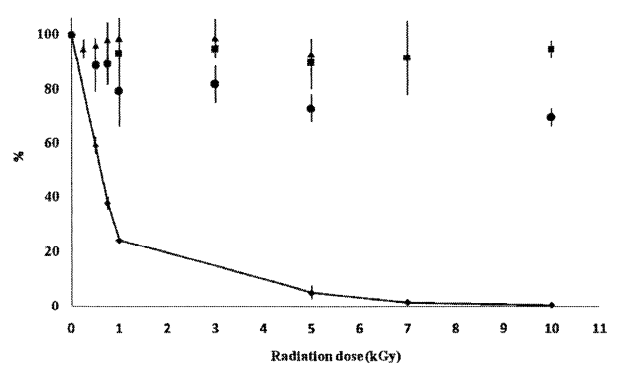

Figure 3. Recovery percentage of FA in powder, suspension, and solution: $(\checkmark)$ FA in solution, ( $\mathbf{\square})$ FA in powder, ( $\mathbf{\Lambda}$ ) FA in suspension, and $(\bullet)$ wheat flour fortified with FA.

important indirect effect because of water radiolysis could have happened, especially with higher doses.

To evaluate the moisture effect in dry samples, such as wheat flour and FA in powder, Karl Fischer titration was performed. In wheat flour samples, the water content averages $13 \%(\mathrm{~m} / \mathrm{m})$. Such a value is highly consistent with previously published data. ${ }^{30}$ Even commercially available FA (in powder) contains on average $8.0-8.5 \%$ of water of hydration. ${ }^{31}$ From our results, FA irradiated in powder, even containing $8 \%$ of water, did not present any statistically significant degradation over a dose range of $1-$ $10 \mathrm{kGy}$ (Figure 3). It suggests that, when non-solubilized, FA is not sensitive to irradiation treatment, at least up to $10 \mathrm{kGy}$. On the other hand, in the fortified wheat flour samples, the FA content showed a very slight degradation (less than $30 \%$ ) when irradiated at doses of 5 and $10 \mathrm{kGy}(p<0.05)$. The higher moisture content and more certainly the food matrix, during irradiation and/or extraction, could have enhanced the irradiation effect in these samples. With regard to the loss of these synthetic vitamer at doses higher than $5 \mathrm{kGy}$, it should be noted that irradiation of grains, cereals, and flours aims for disinfestation. Required doses for this purpose remain below $1 \mathrm{kGy},{ }^{14,15}$ very low absorbed doses, which give no significant reduction of the content of the supplemented vitamer. As signalized by Müller et al. ${ }^{19}$ the relatively high radiation stability of folates contrasts with the observation that conventional processing and culinary preparation destroyed about $50 \%$ of the folate concentration in samples of total diet. Galán et al., ${ }^{20}$ studying the E-beam effect on hamburgers enriched with $\mathrm{FA}$, found $20-30 \% \mathrm{FA}$ reduction following irradiation with $2 \mathrm{kGy}$. Our study showed a similar decrease, nevertheless with a dose range much higher $(5$ and 10 $\mathrm{kGy}$ ). This can be easily explained just by the high moisture content in hamburgers. Müller et al. ${ }^{19}$ observed that the radiation stability of folates was higher in dehydrated spinach, cabbage, and Brussels sprouts than in the fresh material. It is worth saying that in-house fortified wheat flour showed similar quantitative results as those from a commercially available Brazilian wheat flour, showing that the FA radiodegradation does not depend upon the origin of the flour (data not shown).

It became evident that the destruction suffered by dry materials, even when in suspension, as a result of irradiation is much smaller than that in aqueous solution, where indirect effects predominate. Wheat flour fortified with FA showed no loss in its FA content with doses required for disinfestation (up to $1 \mathrm{kGy}$ ).
- AUTHOR INFORMATION

Corresponding Author

*Telephone: +33-390-244-326. Fax: +33-390-244-325. E-mail: eric.marchioni@unistra.fr.

\section{Funding Sources}

We thank CAPES (IPEN/CNEN) and $\mathrm{CNPq}$ for the financial support.

\section{REFERENCES}

(1) United States Pharmacopoeia (USP). United States Pharmaco poeia, 19th ed.; USP: Rockville, MD, 1975; pp 211-212.

(2) Scott, J.; Rébeillé, F.; Fletcher, J. Folic acid and folatcs: The easibility for nutritional enhancement in plant foods. J. Sci. Food Agric $2000,80(7), 795-824$.

(3) Donnelly, J. G. Folic acid. Crit. Rev. Clin. Lab. Sci. 2001, 38, 183-

(4) Molloy, A. M.; Scott, J. M. Folates and prevention of disease Public Health Nutr. 2001, 4, 601-609.

(5) Williams, R. D. FDA proposes folic acid fortification. FDA Consumer; Food and Drug Administration (FDA): Silver Spring, MD May 1994; pp 11-14

(6) McNulty, H.; Pentieva, K. Folate bioavailability. Proc. Nutr. Soc. 2004, 63, 529-536

(7) Melse-Boonstra, A.; Verhoef, P.; West, C. Quantifying folate bioavailability: A critical appraisal of methods. Curr. Opin. Clin. Nutr. Metab. Care 2004, 7, 539-545.

(8) Diário Oficial da União. Resolução RDC Number 344 de Dec 13, 2002; Diário Oficial da União: Brasilia, Brazil, Dec 18, 2002

(9) Ball, G. F. M. Vitamins in Foods: Analysis, Bioavailability, and Stability; CRC Press (Taylor and Francis Group): Boca Raton, FL, 2006, pp 6 and 234

(10) Gregory, J. F. Chemical and nutritional aspects of folate (10) Analytical procedures, methods of folate synthesis, stability and bioavailability of dietary folates. Adv. Food Nutr. Res. 1989, 33 , $1-101$.

(11) Hawkes, J. G.; Villota, R. Folates in foods: Reactivity, stability during processing, and nutritional implications. Crit. Rev. Food Sci. Nut, 1989, 28 (6), 439-538.

(12) McKillop, D. J.; Pentieva, K.; Daly, D.; McPartlin, J. M. Hughes, J.; Strain, J.J. The effect of different cooking methods on folate retention in various foods that are amongst the major contributors to folate intake in the UK diet. Br. J. Nutr. 2002, 88 (6), 681-688.

(13) Farkas, J. Irradiation for better foods. Trends Food $\mathrm{Sci}$. Technol. 2006, 17, 148-152.

(14) World Health Organization (WHO). Safety and Nutritional Adequacy of Irradiated Food; WHO: Geneva, Austria, 1994; pp 23-39. (15) Hayashi, T.; Takahashi, Y.; Todoriki, S. Sterilization of foods with low-energy electrons ("soft-electrons"). Radiat. Pliys. Chem. 1998 $52(1-6), 73-76$

(16) Watanabe, T. Best use of high-voltage, high-powered electron beams: A new approach to contract irradiation service. Radiat. Phys Chem. 2000, $57(3-6), 635-640$.

(17) Tritsch, G. L. Food irradiation. Nutrition 2000, $16(7-8), 698-718$

(18) Morehouse, K. M. Food irradiation-US regulatory considerations. Radiat. Phys. Chem. 2002, 63, 281-284.

(19) Müller, H.; Diehl, J. F. Effect of ionizing radiation on folates in food. Lebensm.Wiss. Technol. 1996, 29, 187-190.

(20) Galán, I; García, M. L.; Selgas, M. D. Fffects of irradiation on hamburgers enriched with folic acid. Meat Sci. 2010, 84, 437-443.

(21) Munyaka, A. W.; Oey, I.; Verlinde, P.; Van Loey, A.; Hendrickx, $M$. Acidification, crushing and thermal treatments can influence the profile and stability of folate poly- $\gamma$-glutamates in broccoli (Brassica profile and stability of folate poly- $\gamma$-glutamates in broc

(22) Akhtar, M. J.; Khan, M. A.; Ahmad, I. Photodegradation of folic (22) Akhtar, M. J.; Khan, M. A.; Ahmad, I. Photodegradation of folic
acid in aqueous solution. J. Pharm. Biomed. Anal. 1999, 25, 269-275. 
(23) Off, M. K.; Steindal, A. E.; Porojnicu, A. C.; Juzeniene, A.; Vorobey, A.; Johnsson, A; Moan, J. J. Ultraviolet photodegradation of folic acid. J. Photochem. Photobiol, B 2005, 80, 47-55.

(24) Kuntz, F.; Pabst, J. Y.; Delpech, J. P.; Wagner, J. P.; Marchioni, E. Alanine-ESR in vivo dosimetry. A feasibility study and possible E. Alanine-ESR in vivo dosimetry. A feasibility study and possible (25) Vis. Appl. Radiat. Isot. 1996, 47, 1183-1188.

(25) Kuntz, F.; Marchioni, E.; Strasser, A. Homogénéisation de la dose déposée dans un produit ionisé aux électrons accélérés. Proceedings of an International Symposium on High Dose Dosimetry for Radiation Processing, Nov 5-9, 1990; The International Atomic Energy Agency: Vienna, Austria, 1991; Report IAEA SM 314/30, pp 479-488.

(26) Alaburda, J.; de Almeida, A. P.; Shundo, L.; Ruvieri, V.; Sabino, M. Determination of folic acid in fortified wheat flours. J. Food Compos. Anal. 2008, 21, 336-342.

(27) von Soontag, C. The Chemical Basis of Radiation Biology; Taylor and Francis: London, U.K., 1987; pp 31-77.

(28) Thomas, A. H.; Suárez, G.; Cabrerizo, F. M.; Martino, R.; Capparelli, A. L. Study of photolysis of folic acid and 6-formylpterin in acid aqueous solutions. J. Photochem. Photobiol, A 2000, 135, 147-154. (29) Guilland, J. C.; Lequeu, B. Encyclopédie des Vitamines, du Nutriment au Médicament. Données Fondamentales: Métabolisme et Fonctions; Editions Lavoisier, Editions Tec \& Doc, Editions Médicales tions; Editions Lavoisier, Editions Tec \& Doc, Editions

(30) Souci, S. W.; Fachmann, W.; Kraut, H. Food Composition and Nutrition Tables, 7th ed,; CRC Press (Taylor and Francis Group): Boca Raton, FL, 2008; pp 688-699.

(31) Temple, C., Jr.; Montgomery, J. A. Chemical and physical properties of folic acid and reduced derivatives. In Folates and Pterins; Blakley, R. L., Benkovic, S. J., Eds.; John Wiley and Sons: New York, 1984; Vol. 1, pp 61-120. 
Radiation Physics and Chemistry I (unu) m-m-m

Contents lists available at SciVerse ScienceDirect

Radiation Physics and Chemistry

journal homepage: www.elsevier.com/locate/radphyschem

\section{LC/MS/MS identification of some folic acid degradation products after E-beam irradiation}

M.M. Araújo ${ }^{\text {a,* }}$, E. Marchioni ${ }^{\text {b }}$, M. Zhao ${ }^{\text {b }}$, F. Kuntz $^{\text {c }}$, T. Di Pascoli ${ }^{b}$, A.L.C.H. Villavicencio ${ }^{a}$, M. Bergaentzle ${ }^{\mathrm{b}}$

a Instituto de Pesquisas Energéticas e Nucleares (IPEN-CNEN/SP), Centro de Tecnologia das Radiações, Av. Prof. Lineu Prestes 2242, 05508-910 Săo Paulo, Brazil ${ }^{\mathrm{b}}$ Equipe de Chimie Analytique des Molécules Bioactives (IPHC-LC4, UMR 7178), Université de Strasbourg. Faculté de Pharmacie, 74 route du Rhin, 67400 Illkirch, France 'Aérial, Centre de Ressources Technologiques, Parc d'Innovation, rue Laurent Fries, BP. 40443, F-67412 Illkirch, France

A R T I C L E I N F O

\section{Article history:}

Aceived 23 June 2011

Accepted 12 November 2011

\section{Keywords:}

Folic acid

E-beam irradiation

Degradation products

LC/MS/MS

\begin{abstract}
A B S T R A C T
Folates belong to the $B$ vitamin group based on the parental compound folic acid (FA). They are involved in important biochemical processes like DNA synthesis and repair. FA is composed of a pteridine ring, p-aminobenzoic acid and glutamate moieties. The human metabolism is not able to synthesize folates and therefore obtain them from diet. FA, a synthetic vitamin, is used as a food fortificant because of its low price, relative stability and increased bioavailability compared to natural folate forms. FA is known to be a sensitive compound easily degradable in aqueous solution by ultraviolet and visible light towards various by-products. Irradiation is a process for preservation of foods that uses accelerated electrons, gamma rays or X-rays. Irradiation is proposed for the treatment of various food products, eliminating or reducing pathogens and insects, increasing the storage time and replacing chemical fumigants. This study concerns the identification of degradation products of FA after E-beam irradiation. FA aqueous solutions were irraliated with a Van de Craaff electrons beam accelerato (2 MeV 100 a current, $20 \mathrm{~cm}$ scan width, dose rate a Vant $2 \mathrm{kCy} / \mathrm{s}$ ) Applied doses were between ( $2 \mathrm{MeV}, 100 \mu \mathrm{A}$ current, $20 \mathrm{~cm}$ scan width, dose rate about $2 \mathrm{kGy} / \mathrm{s}$ ). Applied doses were between
\end{abstract} ๑ 2011 Published by Elsevier Ltd.

\section{Introduction}

Folic acid (FA) is the parent compound of the folates watersoluble vitamins. As shown in Fig. $1, \mathrm{FA}\left(\mathrm{C}_{19} \mathrm{H}_{19} \mathrm{~N}_{7} \mathrm{O}_{6}, \mathrm{MW}=441.4\right)$ is composed of a pteridine ring, p-aminobenzoic acid (PABA) and glutamate moieties. FA is the synthetic oxidized and most stable form of folates. FA is an orange-yellow, microcrystalline, almost odorless, tasteless powder (Lucock, 2000; Ball, 2006).

Humans do not synthesize folates and therefore have to get them from food. Folates are attracting considerable interest in the field of nutrition due to the growing amount of evidence pointing to the contribution of inadequate folate intake to severe health disorders such as neural tube defects (Tamura and Picciano, 2006), cardiovascular disease (Moat et al., 2001), neuropsychiatric disorders (Selhub et al., 2000) and some types of cancer (Kim, 2007).

The stability of folates during food processing is influenced by temperature, duration of heating pressure, $\mathrm{pH}$ radiation dose, oxygen, light, metal ions and antioxidants moieties (McKillop et al.,

\footnotetext{
E-mail addresses: mmozeika@yahoo.com.

mozeika@hotmailcom (M.M. Araújo), eric.marchioni@unistra.fr (E. Marchioni) florent.kuntz@aerial-crt.com (F. Kuntz).
}

0969-806X/\$ - see front matter 02011 Published by Elsevier Ltd. doi:10.1016/j.radphyschem.2011.11.029
2002; Indrawati et al., 2004; Verlinde et al., 2008; Araujo et al., 2011). Degradation of this molecule may result from scission reaction such as cleavage of the $\mathrm{C}^{9}-\mathrm{N}^{10}$ covalent bond, which results in irreversible loss of vitamin activity (Murphy et al., 1976; McKillop et al., 2002)

Radiation treatment is a process exposing food to ionizing radiations such as gamma rays emitted from the radioisotopes ${ }^{60} \mathrm{Co}$, or high energy electrons and $\mathrm{X}$-rays produced by machine sources. Depending on the absorbed radiation dose, various effects can be achieved resulting in reduced storage losses, extended shelf life and/or improved microbiological and parasitonogical safety of macronutrients such as proteins and carbohydrates are relatively stable at doses up to $10 \mathrm{kGy}$, and micronutrients, especially vitamins, may be sensitive to any food treatment (Villavicencio et al., 2000).

In this study, the stability of the synthetic form FA was investigated after E-beam irradiation in aqueous solution. The main purpose of this research was to perform a detailed study on FA degradation due to irradiation treatment. At first, degradation of FA after irradiation treatment was evaluated in a wide range of radiation doses to identify the radiation dose range of interest. Later on, predominant degradation products were analyzed and identified to investigate possible degradation mechanisms. 


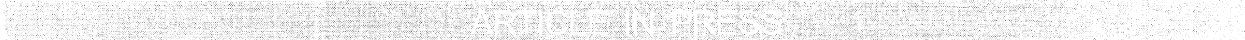

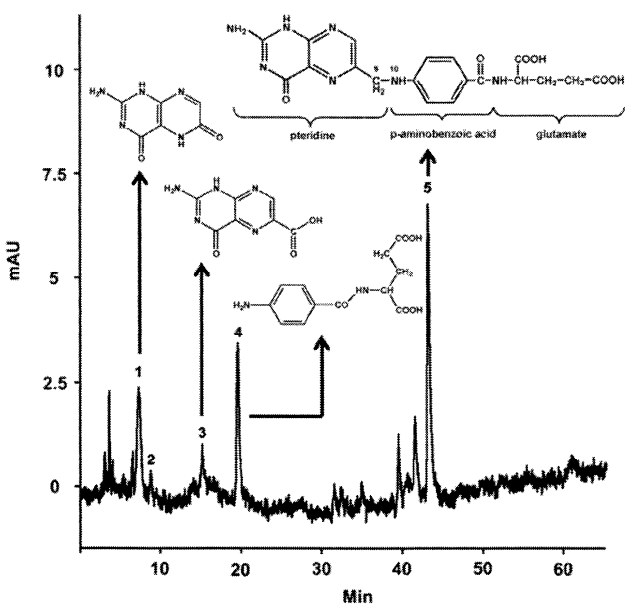

Fig. 1. LC/UV chromatogram of FA solution irradiated at $5 \mathrm{kGy}$ and degradation products $(1,2,3,4)$ of folic acid $(5)$.

\section{Experimental}

\subsection{Materials}

Methanol (MeOH) (Carlo Erba, Val de Reuil, France) and acetonitrile (ACN) (Sigma-Aldrich, Steinheim, Germany) were high-performance liquid chromatography (HPLC) grade. All other chemicals were of analytical grade. Acetic acid was purchased from Riedel-de-Haen/Fluka (Seelze, Germany). Sodium hydroxide $(\mathrm{NaOH})$ was purchased from SDS (Peypin, France). FA and degradation products pterine-6-carboxilic acid (PCA), p-aminobenzoylL-glutamic acid (pABGA) and p-aminobenzoic acid (PABA) were obtained from Sigma-Aldrich (Steinheim, Germany). Xanthopterin monohydrate (XA) was purchased from Acros Organics (Geel, Belgium). Water was purified using a Synergy Milli-Q System (Millipore, Molsheim, France)

\subsection{Samples}

All folic acid standard solutions were prepared under subdued light, to protect folates from oxidative degradation induced by light. Solutions were prepared as following: a total of $200 \mathrm{mg}$ of FA was added to $200 \mathrm{~mL}$ of water and solubilized by the addition of $10 \mathrm{~mL}$ of $1 \mathrm{M} \mathrm{NaOH}$. The solution was diluted in water to a final concentration of $0.1 \mathrm{mg} / \mathrm{mL}$, resulting in a $\mathrm{pH}$ of 11 . All samples ( $4 \mathrm{~mm}$ thick) were packed in polyamide/polyethylene plastic sachets, sealed and labeled with their respective radiation doses. $\mathrm{PABA}$ and $\mathrm{PABGA}$ were dissolved and diluted in water $\mathrm{pH}$ 7.0 while PCA and XA were dissolved and diluted in alkaline water, all of them at a final concentration of $0.1 \mathrm{mg} / \mathrm{mL}$.

\subsection{Irradiation treatment}

FA aqueous solutions were irradiated with a Van de Graaf E-beam accelerator, $2 \mathrm{MeV}$ (Vivirad High Voltage, Handschuheim, France) with a $100 \mu \mathrm{A}$ current, $20 \mathrm{~cm}$ scan width and about $2 \mathrm{kGy} / \mathrm{s}$ dose rate. Applied doses were 0 (control), 0.24, 0.46 $0.72,0.95,2.9,5.0,7.0$ and $10.1 \mathrm{kGy}$. Surface absorbed doses were monitored with FWT 60.00 radiochromic dosimeters (Far West
Technology, Goleta, CA), previously calibrated with an alanine dosimeter (Aérial, Illkirch, France) (Kuntz et al., 1996). Dose uniformity of about $10 \%$ within the sample was achieved by the use of a $100 \mu \mathrm{m}$ thick copper scattering foil (Kuntz et al., 1990). During irradiation, standard conditions for temperature and pressure were used $\left(25^{\circ} \mathrm{C}\right.$ and $\left.14.69 \mathrm{psi}\right)$.

\section{4. $L C / M S / M S$}

Experimental work was performed using a Varian ProStar HPLC system (Palo Alto, CA) [210 binary HPLC pump, 410 AutoSampler and 335 diode array detection (DAD) UV-vis detecAutoSampler and 335 diode array detection (DAD) UV-vis detec-
tor]. A Varian $1200 \mathrm{~L}$ triple quadrupole mass spectrometer system (MS) (Varian, Les Ulis, France) was used for the identification of degradation products. High-purity nitrogen (Domnik Hunter, Villefranche sur Saône, France) was used as nebulizing gas, set at $46 \mathrm{psi}$, and as a drying gas, set at $200{ }^{\circ} \mathrm{C}$. The spectrometer was operated in scan mode $(70-500 \mathrm{~m} / z)$ using positive electrospray ionization (ESI). Chromatographic separation was carried out on a Agilent-XDB Phenyl analytical column $(250 \mathrm{~mm} \times 4.6 \mathrm{~mm} ; 5 \mu \mathrm{m}$ particle size), whereas the eluate was split at the ratio of $1: 5$ before entering the MS. Mobile phase consisted of aqueous acetic acid $(0.5 \%)$ and $\mathrm{MeOH}$, at a flow rate of $1.0 \mathrm{~mL} / \mathrm{min}$. Gradien elution started at $100 \%$ aqueous acetic acid maintained for $10 \mathrm{~min}$, followed by raising the $\mathrm{MeOH}$ concentration linearly to $60 \%$ within 56 min. MeOH concentration was maintained for $60 \%$ within $56 \mathrm{~min}$. $\mathrm{MeOH}$ concentration was maintained for $4 \mathrm{~min}$. Subsequently, the $\mathrm{MeOH}$ concentration decreased to $0 \%$
in $1 \mathrm{~min}$, and then the column was equilibrated at this condition for $9 \mathrm{~min}$. An injection volume of $20 \mu \mathrm{L}$ was used.

Confirmation analysis was performed using a high resolution mass spectrometer (HRMS) (Agilent Technologies, Massy, France) [G1312B binary pump, G1367C AutoSampler, DAD SL G1315C detector, MS 6520 Accurate Mass Q-TOF]. Chromatographic separation was carried out on a Thermo Hypersil Gold C8 analytical column $(100 \mathrm{~mm} \times 1.0 \mathrm{~mm} ; 1.9 \mu \mathrm{m}$ particle size $)$ Mobile phase consisted of aqueous formic acid $(0.05 \%)$ and $\mathrm{ACN}$ at a flow rate of $0.1 \mathrm{~mL} / \mathrm{min}$. Gradient elution started at $100 \%$ aqueous formic acid maintained for $2 \mathrm{~min}$, followed by raising the ACN concentration linearly to $95 \%$ within 6 min. ACN concentration was maintained for $6.5 \mathrm{~min}$. Subsequently, the ACN concentration decreased to $0 \%$ in $0.5 \mathrm{~min}$. An injection volume of $0.4 \mu \mathrm{L}$ was used.

\section{Results}

Increasing absorbed radiation doses promoted a decrease in FA concentration, as noted by other authors (Müller and Diehl, 1996; Araujo et al., 2011). FA aqueous solutions also showed different chromatographic profiles depending on radiation doses applied. Low radiation doses (up to $1 \mathrm{kGy}$ ) caused mainly the appearance of less polar degradation products which present close $m / z$ to FA and surround FA retention time (Fig. 1, peak 5) (HPLC chromatogram not shown). On the other hand, padiation doses over $5 \mathrm{kc}$ not shown). On moted an intense (low $m / z$ ) compared to FA $m / z$ of polar nature appeared (Fig. 1).

Three of these more polar degradation products due to E-beam treatment were clearly identified and meets to already known FA degradation products. Even at doses around $1 \mathrm{kGy}$ these radiation degradation products could be detected. The first one, represented by the peak at retention time $(t) 15.2$ min yielded a $\left[\mathrm{M}+\mathrm{H}^{+}\right.$of . This peak represented a $\mathrm{C}^{9}-\mathrm{N}^{10}$ bond cleavage, resulting in the formation of pterine-6-carboxilic acid (PCA) $\left(\mathrm{C}_{7} \mathrm{H}_{5} \mathrm{~N}_{5} \mathrm{O}_{3}\right)$ (Fig. 1 , peak 3). It was also observed a $m / z 229.9$, due to sodium adduct $[\mathrm{M}+\mathrm{Na}]^{+}$. The second one, at $t_{\mathrm{r}}=19.5 \mathrm{~min}, \mathrm{a}[\mathrm{M}+\mathrm{H}]^{+}$of $\mathrm{m} / \mathrm{z}$ 267.0 was found representing the loss of the pteridine group

Please cite this article as: Araújo, M.M., et al., LC/MS/MS identification of some folic acid degradation products after E-beam irradiation. Radiat. Phys. Chem. (2011), doi:10.1016/j.radphyschem.2011.11.029 
Table 1

FA degradation products and their corresponding $t_{\mathrm{r}}, \mathrm{m} / \mathrm{z}$ (MS), $\mathrm{m} / \mathrm{z}$ (HRMS) and empirical formula.

\begin{tabular}{lclll}
\hline Compound & $\begin{array}{l}\text { Retention time } \\
(\mathbf{m i n})\end{array}$ & $\begin{array}{l}\mathbf{M S} \\
{\left[\mathbf{M}+\mathbf{H}^{+}\right.}\end{array}$ & $\begin{array}{l}\text { HRMS } \\
{[\mathbf{M}+\mathbf{H}]^{+}}\end{array}$ & $\begin{array}{l}\text { Empirical } \\
\text { formula }\end{array}$ \\
\hline XA & 7.5 & 180.0 & 180.0518 & $\mathrm{C}_{6} \mathrm{H}_{5} \mathrm{~N}_{5} \mathrm{O}_{2}$ \\
Unkown & 9.5 & 194.0 & 194.0676 & $\mathrm{C}_{7} \mathrm{H}_{7} \mathrm{~N}_{5} \mathrm{O}_{2}$ \\
$\quad$ compound & & & & \\
PCA & 15.2 & 208.0 & 208.0464 & $\mathrm{C}_{7} \mathrm{H}_{5} \mathrm{~N}_{5} \mathrm{O}_{3}$ \\
PABA & 19.0 & 138.0 & 138.0549 & $\mathrm{C}_{7} \mathrm{C}_{5} \mathrm{NO}_{2}$ \\
pABGA & 19.5 & 267.0 & 267.0992 & $\mathrm{C}_{12} \mathrm{H}_{14} \mathrm{~N}_{2} \mathrm{O}_{5}$ \\
\hline
\end{tabular}

moiety, arising the p-aminobenzoyl-L-glutamic acid (pABGA) $\left(\mathrm{C}_{12} \mathrm{H}_{14} \mathrm{~N}_{2} \mathrm{O}_{5}\right)$ (Fig. 1, peak 4). It was also observed $\mathrm{m} / \mathrm{z} 289.0$, due to sodium adduct $[\mathrm{M}+\mathrm{Na}]^{+}$. The presence of sodium adducts is well known in mass spectrometry due to the current use of glass containers for solvents. In our case the presence of sodium adducts might be also due to the use of a $\mathrm{NaOH}$ solution to dissolve FA in water. Moreover, in the same mass spectrum, an $\mathrm{m} / \mathrm{z}$ of 119.9 was observed representing the loss of the glutamate moiety. Also trace of $m / z 138.0[\mathrm{M}+\mathrm{H}]^{+}$was found in irradiated FA aqueous solutions $\left(t_{\mathrm{r}}=19.0 \mathrm{~min}\right)$. It corresponds to the loss of both pteridine ring and glutamate moieties, resulting in p-aminobenzoic acid (PABA) $\left(\mathrm{C}_{7} \mathrm{H}_{7} \mathrm{NO}_{2}\right)$. The identification of PCA. PABA and PABGA in irradiated FA solutions were confirmed by comparing their $t_{\mathrm{r}}$, UV and MS/MS spectra with these degradation products standards in $\mathrm{LC} / \mathrm{UV} / \mathrm{MS}^{2}$ chromatograms (data not shown).These evidences were also confirmed by high resolution mass spectrometry, resulting in a $m / z$ of $208.0464,138.0549$ and $267.0992[\mathrm{M}+\mathrm{H}]^{+}$, respectively to PCA, PABA and pABGA (Table 1).

Besides the known degradation products, other peaks were also observed in LC/UV/MS chromatograms (Fig. 1). One of them $\left(t_{\mathrm{r}}=7.5 \mathrm{~min}\right)$, presented a $\mathrm{m} / \mathrm{z}$ of $180.0[\mathrm{M}+\mathrm{H}]^{+}$(Fig. 1, peak 1). High resolution mass spectrometry showed that this new compound has an empirical formula of $\mathrm{C}_{6} \mathrm{H}_{5} \mathrm{~N}_{5} \mathrm{O}_{2}$ and $\mathrm{m} / \mathrm{z}$ of 180.0518, which was supposed to be xanthopterin. This hypothesis was confirmed by analysis of xanthopterin standard which showed the same $t$ UV and MS/MS spectra in IC/UV/MS ${ }^{2}$ chromatograms. Another neo-formed product was detected at $t_{\mathrm{r}}=9.6 \mathrm{~min}$ and presented a $\mathrm{m} / \mathrm{z} 194.0[\mathrm{M}+\mathrm{H}]^{+}, 175.9[\mathrm{M}+$ $\left.\mathrm{H}^{-} \mathrm{H}_{2} \mathrm{O}\right]^{+}$and $\mathrm{m} / z 215.9[\mathrm{M}+\mathrm{Na}]^{+}$(Fig. 1, peak 2). From HRMS analysis, it was found an empirical formula of $\mathrm{C}_{7} \mathrm{H}_{7} \mathrm{~N}_{5} \mathrm{O}_{2}$ and a $\mathrm{m} / \mathrm{z}$ $194.0676[\mathrm{M}+\mathrm{H}]^{+}$(Table 1$)$

\section{Discussion}

Some of our findings are already well-known FA breakdown products. Tannenbaum et al. (1985) have already showed that alkaline hydrolysis under aerobic conditions promotes oxidative cleavage of the FA molecule to yield pABGA and PCA. Vora et al. (2002), in a study of the thermal stability of FA, proposed that first folic acid loss the glutamate moiety and then pterin and PABA decomposes in an overlapping mechanism.

Our results are in accordance with those found after photolysis of FA. The first study published by Lowry et al. (1949), had already proposed that after photolysis FA finally degrades to PABGA and PCA. Saxby et al. (1983) evaluated the effect of sulfur dioxide $\left(\mathrm{SO}_{2}\right)$ on the stability of $\mathrm{FA}$ in aqueous solution and in beer, both at $\mathrm{pH}$ 5. They stated that FA stored in the light degraded to a mixture of three compounds, PCA, pABGA and probably 6 -methylpterin and $\mathrm{SO}_{2}$ played a protective role. In beer, the presence of $\mathrm{SO}_{2}$ had no effect on the degradation of $\mathrm{FA}$, which decomposed finally to the same products. No approach was done with regard to the type of light applied in these previous studies.
Afterwards, several studies were performed (Akhtar et al., 1997, 1999, 2003; Thomas et al., 2000; Off et al., 2005; Vorobey et al., 2006: Dántola et al.. 2010) focusing on the photolysis of FA under UV light. They have proposed that after UV irradiation, FA first undergoes a cleavage at the $\mathrm{C}^{9}-\mathrm{N}^{10}$ bond with formation of pABGA and 6-formylpterin (FPT) $\left(\mathrm{C}_{7} \mathrm{H}_{5} \mathrm{~N}_{5} \mathrm{O}_{2}\right.$, MW: 191). Further pABGA and 6-formylpterin (FPT) $\left(\mathrm{C}_{7} \mathrm{H}_{5} \mathrm{~N}_{5} \mathrm{O}_{2}\right.$, MW: 191). Further FPT and thus formation of PCA. Also, both photoproducts, FPT and PCA, can act as sensitizers in the photodegradation of FA. In this study, after E-beam treatment no trace of FPT was detected, probably due to the high energy involved in E-beam treatment that accelerated PCA formation. E-beam treatment promoted FA degradation into similar degradation products as UV treatment, but also new breakdown products. That is understandable because E-beam processing is an in-depth treatment, more energetic and with higher dose rates than UV treatment.

A few works have already tried to elucidate the degradative process of FA after irradiation treatment, yielding mainly PCA and pABGA as degradation products, similarly to our data. Nakken and Pihl (1966) studied the X-ray induced degradation of folic acid, p-aminobenzoic acid conjugates, $\mathrm{N}$-(p-aminobenzoyl)glutamic acid and $\mathrm{N}$-(p-aminobenzoyl)glycine under $\mathrm{pH}$ 7.4. They also proposed that one susceptible point of attack for radiation-induced radicals might be the $\mathrm{C}^{9}-\mathrm{N}^{10}$ linkage, resulting in pABGA and PCA products. Also 3-OH-pABGA and o-amino-phenols were found. In another study, Kesavan et al. (2003) evaluated the effect of total body gamma irradiation (TBI) $(2,5,7 \mathrm{~Gy})$ in mice. They also observed that after TBI the folate molecule was split into pterin and PABGA due to oxidative damage.

Further investigations are under analysis in order to enlighten the chemical structure of other FA radiation degradation products as well as the mechanism of FA degradation after E-beam treatment.

\section{Conclusions}

E-beam treatment with radiation doses over $1 \mathrm{kGy}$ promoted an intense FA breakdown. FA molecule was cleaved not only into already known degradation products PCA, pABGA and PABA, but also into other products. One of them was identified as xanthopterin, a new radio-induced breakdown product.

\section{Acknowledgments}

We thank CAPES, IPEN/CNEN and CNPq for the financial support.

\section{References}

Akhtar, M.J., Khan, M.A., Ahmad, I., 1997. High performance liquid chromatographic determination of folic acid and its photodegrader.

. Po folic acid in aqueous solution. J. Pharm. Biomed. Anal. 25, 269-275.
s.t.

Akhtar, M.J., Khan, M.A., Ahmad, I., 2003. Identification of photoproducts of folic acid and its degradation products pathways in aqueous solution. J. Pharm. Biomed. Anal. 31, 579-588.

Araujo, M.M., Marchioni, E., Bergaentzle, M., Zhao, M., Kuntz, F., Hahn, E.

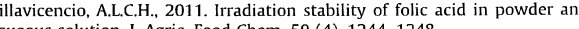
aqueous solution. J. Agric. Food Chem. 59 (4), 1244-1248. Press (Taylor and Francis Group, Florida.

Dántola, M.L., Denofrio, M.P., Zurbano, B., Gimenez, C.S., Ogilby, P.R., Lorente, C. Thomas, A.H., 2010. Mechanism of photooxidation of folic acid sensitized by unconjugated pterins. Photochem. Photobiol. Sci. 9, 1604-1612

Farkas, J., 2006. Irradiation for better foods. Trends Food Sci. Technol. 17. 148-152 Indrw. drofolic acid in model systems and in food products. J. Agric. Food Chem. 52 (3), 485-492 
Kesavan, V., Pote, M.S., Batra, V., Viswanathan, G., 2003. Increased folate catabolism following total body gamma-irradiation in mice. J. Radiat. Res. 44, $141-144$.

Kim, Y.I., 2007. Folate and colorectal cancer: an evidence-based critical review.

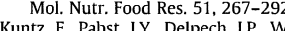

untz, F., Pabst, J.Y., Delpech, J.P., Wagner, J.P., Marchioni, E., 1996. Alanine-ESR in vivo dosimetry. A
Isot. $47,1183-1188$.

Kuntz, F., Marchioni, E., Strasser, A., 1991. Homogénéisation de la dose déposée dans un produit ionisé aux électrons accélérés. In: Proceedings of the International Symposium on High Dose Dosimetry for Radiation Processing November 5-9, 1990, The International Atomic Energy Agency, Vienna, Austria, Report IAFA SM 314/30, pp. 479-488.
(n)

Lwry, O.H., Bessey, O.A., Crawford, E.J., 1949. Photolytic and enzymatic transformations of pteroylglutamic acid. J. Biol. Chem. 180 (1), 389-398.
cock, M., 2000. Folic acid: nutritional biochemistry, molecular biology and rol in disease processes. Mol. Genet. Metab. 71, 121-138.

McKillop, D., Pentieva, K., Daly, D., McPartlin, J., Hughes, J., Strain, J., Scott, J. McNulty, H., 2002. The effect of different cooking methods on folate retentio in various foods that are amongst the major contributors to folate intake in the
UK diet. Br. J. Nutr. 88, 681-688.

Moat, S., Lang, D., McDowell, I., Clarke, Z., Madhavan, A., Lewis, M., Goodfellow, J., 2004. Folate, homocysteine, endothelial function and cardiovascular disease. J. Nutr. Biochem. 15, 64-79,

Müller, H., Diehl, J.F., 1996. Effect of ionizing radiation on folates in food. Lebensm.-Wiss. Technol. 29, 187-190

urphy, M., Keating, M., Boyle, P., Weir, D.G., Scott, J.M., 1976. The elucidation of (he
Nakken, K.F., Pihl, A., 1966. The X-ray-induced damage to the p-aminobenzoic acid moiety of folic acid and some other p-aminobenzoic acid conjugates irradiated in solu

off, M.K., Steindal, A.E., Porojnicu, A.C., Juzeniene, A., Vorobey, A., Johnsson, A. Moan, J., 2005. Ultraviolet photodegradation of folic acid. J. Photochem. axby, M.J., Smith, P.R., Bla

(19. The degradation of folic acid in a model food system and in beer. Food Chem. 12, 115-126.

Selhub, J., Bagley, L., Miller, J., Rosenberg, I., 2000. B vitamins, homocysteine, and neurocognitive function in the elderly. Am. J. Clin. Nutr. $1,6145-620 \mathrm{~S}$. mura, T., Picciano, M.F., 2006. Folate and human reproduction. Am. J. Clin. Nutr. $83,993-1016$.
8annenhaum, S R

Tannenhaum, S.R., Young. V.R., Archer, M.C., 1985. Vitamins and minerals. In 477)

Thomas, A.H., Suárez, G., Cabrerizo, F.M., Martino, R., Capparelli, A.L., 2000. Study of the photolysis of folic acid and 6-formylpterin in acid aqueous solutions J. Photochem. Photobiol. A 135, 147-154.

Verlinde, P., Oey, I., Hendrickx, M., Van Loey, A. 2008. High pressure treatments induce folate polyglutamate profile changes in intact broccoli (Brasica tissue Food Chem. 111 (1), 220-229.

P. Steindal, A.E., Off, M.K., Vorobey, A., Moan, J., 2006. Influence of human

serum albumin on photodegradation of folic acid in solution. Photochem.
Photobiol. 82, 817-822. Vevicencio, A.L.C.H., Mancini-Filho, J., Delinceé, H., Bognar, A., 2000. Effect of gamma irradiation on the thiamine, riboflavin and vitaniuin $B 6$ content in two al stability of folic acid. Thermochim. Acta 392-393, 209-220.

Please cite this article as: Araújo, M.M., et al., LC/MS/MS identification of some folic acid degradation products after E-beam irradiation. Radiat. Phys. Chem. (2011), doi:10.1016/j.radphyschem.2011.11.029 


\section{REFERÊNCIAS BIBLIOGRÁFICAS}

1 AKHTAR, M.J.; KHAN, M.A.; AHMAD, I. High performance liquid chromatographic determination of folic acid and its photodegradation products in the presence of riboflavin. J. Pharm. Biomed. Anal., v.16, p. 95-99, 1997.

2 AKHTAR, M.J.; KHAN, M.A.; AHMAD, I. Photodegradation of folic acid in aqueous solution. J. Pharm. Biomed. Anal., v. 25, p. 269-275, 1999.

3 AKHTAR, M.J.; KHAN, M.A.; AHMAD, I. Identification of photoproducts of folic acid and its degradation products pathways in aqueous solution. J. Pharm. Biomed. Anal., v. 31, p. 579-588, 2003.

4 ALABURDA, J.; DE ALMEIDA, A.P.; SHUNDO, L.; RUVIERI, V.; SABINO, M. Determination of folic acid in fortified wheat flours. J. Food Compos. Anal., v. 21, p. 336-342, 2008.

5 ALOTHMAN, M.; BHAT, R.; KARIM, A.A. Effects of radiation processing on phytochemicals and antioxidants in plant produce. Trends Food Sci. Tech., v. 20, p. 201-212, 2009.

6 ANDERSON, W.A.; SLAUGHTER, D.; LAFFEY, C.; LARDNER, C. Reduction of folic acid during baking and implications for mandatory fortification of bread. Int. J. Food Sci. Technol., v. 45, p. 1104-1110, 2010.

7 ARAUJO, M.M.; MARCHIONI, E.; BERGAENTZLE, M.; ZHAO, M.; KUNTZ, F.; HAHN, E.; VILLAVICENCIO, A.L.C.H. Irradiation stability of folic acid in powder and aqueous solution. J. Agric. Food Chem., v. 59, n. 4, p. 1244 - 1248, 2011.

8 ARCOT, J.; SHRESTHA, A. K.; GUSANOV, U. Enzyme protein binding assay for determining folic acid in fortified cereal foods and stability of folic acid under different extraction methods. Food Control, v. 13, p. 245-252, 2002.

9 ARCOT, J.; SHRESTHA, A. Folate: methods and analysis. Trends Food Sci. Tech., v. 16, p. 253-266, 2005.

10 BAILEY, L.B.; GREGORY, J.F. Folate metabolism and requeriments. J. Nutr., v. 129, p. 779-782, 1999.

11 BAILEY, L. Handbook of vitamins. Boca Raton, FL, EUA: CRC Press, 2007.

12 BALL, G.F.M., Vitamins in Foods: Analysis, Bioavailability and Stability, Florida, FL: CRC Press (Taylor and Francis Group), 2006.

13 BOWLEY, A. Mandatory food enrichment. Basel, Roche Vitamins Europe Ltd, 2003. 
14 BRASIL. ANVISA. Resolução RDC No. 21 de 26/01/2001. Aprova regulamento técnico para irradiação de alimentos. Diário Oficial da União: 29/01/2001.

15 BRASIL. Resolução RDC No. 344 de 13/12/2002; Diário Oficial da União: $18 / 12 / 2002$.

16 BRASIL (ANVISA). Resolução RDC No. 269 de 22/09/2005; Diário Oficial da União: 23/09/2005.

17 CALVEL, R. O Pão Francês e os produtos correlatos: Tecnologia e prática da panificação. Fortaleza, Ceará: Editora J. Macêdo S.A, 1987.

18 CHEN, J. H.; LI, W. L.; YANG, B. J.; GUO, X. C. Determination of four major saponins in the seeds of Aesculus Chinensis Bunge using pressurized liquid extraction followed by high-performance liquid chromatography and electrospraytime of flight mass spectrometry. Anal. Chim. Acta, v. 596, p. 273-280, 2007.

19 CHEUNG, R. H. F.; MORRISON, P. D.; SMALL, D. M.; MARRIOTT, P. J. Investigation of folic acid stability in fortified instant noodles by use of capillary electrophoresis and reversed-phase high performance liquid chromatography. $\boldsymbol{J}$. Chromatogr. A, v. 1213, p. 93-99, 2008.

$20 \mathrm{CHO}$, S. K.; ELATY, A. M.; CHOI, J. H.; KIM, M. R.; SHIM, J. H. Optimized conditions for the extraction of secondary volatile metabolites in Angelica roots by pressurized liquid extraction. J. Pharmaceut. Biomed., v. 44, p. 1154-1158, 2007.

21 COUTE, E.; MILANI, R.; MORALI, G. Comparison between pressurized liquid extraction and traditional extraction methods for the analysis of the herbicide diflufenican in soil. J. Chromatogr. A, v. 765, p. 121-125, 1997.

22 CRIDER, K.S.; BAILEY, L.B.; BERRY, R.J. Folic acid food fortification - its history, effect, concerns, and future directions. Nutrients, v. 3, n. 3, p. 370-384, 2011.

23 DAMODARAN, S.; PARKIN, K.L.; FENNEMA, O.R. Química de alimentos de Fennema. Porto Alegre, Brasil: Artmed, 2010.

24 DÁNTOLA, M.L.; DENOFRIO, M.P.; ZURBANO, B.; GIMENEZ, C.S.; OGILBY, P.R.; LORENTE, C.; THOMAS, A.H. Mechanism of photooxidation of folic acid sensitized by unconjugated pterins. Photochem. Photobiol. Sci., v. 9, p. 1604-1612, 2010.

25 DIEHL, J.F. Safety of Irradiated Foods; Marcel Dekker Inc.: New York, EUA, 1995; p. 91-115.

26 DUNFORD, N. T. \& ZHANG, M. T. Pressurized solvent extraction of wheat germ oil. Food. Res. Int., v. 36, p. 905-909, 2003.

27 FANARO, G.B.; DUARTE, R.C.; ARAÚJO, M.M.; PURGATTO, E.; VILLAVICENCIO, A.L.C.H. Evaluation of gamma-radiation on green tea odor volatiles. Radiat. Phys. Chem., v. 80, p. 85-88, 2011. 
28 FARKAS, J. Irradiation for better foods. Trends Food Sci. Tech., v. 17, p. $148-152,2006$.

29 FARKAS, J.; MOHÁCSI-FARKAS, C. History and future of food irradiation. Tren. Food Scien. Technol., v. 22, p. 121-126, 2011.

30 FREITAS, L. D. S.; JACQUES, R. A.; RICHTER, M. F. Pressurized liquid extraction of vitamin E from Brazilian grap seed oil. J. Chromatogr. A, v. 1200, p. 80-83, 2008.

31 GALÁN, I.; GARCÍA, M. L.; SELGAS, M. D. Effects of irradiation on hamburgers enriched with folic acid. Meat Sci., v. 84, p. 437-443, 2010.

32 GREGORY, J. F. Chemical and nutritional aspects of folate research: analytical procedures, methods of folate synthesis, stability, and bioavailability of dietary folates. Adv. Food Nutr. Res., v. 33, p. 1-101, 1989.

33 GUILLAND, J. C.; LEQUEU, B. Encyclopédie des Vitamines, du Nutriment au Médicament. Données Fondamentales: Métabolisme et Fonctions; Editions Lavoisier, Editions Tec \& Doc, Editions Médicales Internationales: Paris, France, 2009.

34 GUJSKA, E.; MAJEWSKA, K. Effect of baking process on added folic acid and endogenous folates stability in wheat and rye breads. Plant Food Human Nutr., v. 60 , n. 2, p. 37-42, 2005.

35 HAYASHI, T.; TAKAHASHI, Y.; TODORIKI, S. Sterilization of foods with low-energy electrons ("Soft-Electrons"). Radiat. Phys. Chem., v. 52, n. 1-6, p. 73-76, 1998.

36 HELDMAN, D.R.; LUND, D.B. Handbook of Food Engineering. Boca Raton, FL, EUA: CRC Press, Taylor \& Francis Group, 2007.

37 HUGHES, J.; BUTTRISS, J. An update on folates and folic acid: contribution of MAFF-funded research. Br. Nutr. Found. Nutr., v. 25, p. 113-124, 2000.

38 INDRAWATI, ARROQUI, C.; MESSAGIE, I.; NGUYEN, M.T.; VAN LOEY, A.; HENDRICKX, M. Comparative study on pressure and temperature stability of 5-methyltetrahydrofolic acid in model systems and in food products. J. Agric. Food Chem., v. 52, n. 3, p. 485-492, 2004.

39 JANSEN, B.; NIEROP, K. G. J.; KOTTE, M. C. The applicability of pressurized liquid extraction (PLE) to extract lipid biomarkers from soils. Appl. Geochem., v. 21, p. 1006-1015, 2006.

40 KESAVAN, V.; POTE, M.S.; BATRA, V.; VISWANATHAN, G. Increased folate catabolism following total body gamma-irradiation in mice. J. Radiat. Res., v. 44, p. $141-144,2003$.

41 KIM, Y.I. Folate and colorectal cancer: an evidence-based critical review. Mol. Nutr. Food Res., v. 51, p. 267-292, 2007. 
42 KITAZURU, E.R.; MOREIRA, A.V.B.; MANCINI-FILHO, J.; DELINCEÉ, H.; VILLAVICENCIO, A.L.C.H. Effects of irradiation on natural antioxidants of cinnamon (Cinnamomum zeylanicum N.). Rad. Phys. Chem., v. 71, p. 37-39, 2004.

43 KUNTZ, F.; PABST, J.Y.; DELPECH, J.P.; WAGNER, J.P.; MARCHIONI, E. Alanine-ESR in vivo dosimetry. A feasibility study and possible applications. Appl. Radiat. Isot., v. 47, p. 1183-1188, 1996.

44 KUNTZ, F.; MARCHIONI, E.; STRASSER, A. Homogénéisation de la dose déposée dans un produit ionisé aux électrons accélérés. In: INTERNATIONAL SYMPOSIUM ON HIGH DOSE DOSIMETRY FOR RADIATION PROCESSING, Nov 5-9, 1990, Vienna. Proceedings. IAEA (International Atomic Energy Agency), Report IAEA SM 314/30, 1991. p. 479-488.

45 LESKOVÁ, E.; KUBIKOVA, J.; KOVACIKOVA, E.; KOSICKA, M.; PORUBSKA, J.; HOLCIKOVA, K. Vitamin losses: Retention during heat treatment and continual changes expressed by mathematical models. J. Food Compos. Anal., v. 19, p. 252-276, 2006.

46 LOWRY, O.H.; BESSEY, O.A.; CRAWFORD, E.J. Photolytic and enzymatic transformations of pteroylglutamic acid. J. Biol. Chem., v. 180, n. 1, p. 389-398, 1949.

47 LUCOCK, M. Folic acid: nutritional biochemistry, molecular biology, and role in disease processes. Mol. Genet. Metabol., v. 71, p. 121-138, 2000.

48 MACNAUGHTON, S. J.; JENKINS, T. L.; WIMPEE, M. H.; CORMIER, M. R.; WHITE, D. C. Rapid extraction of lipid biomarkers from pure culture and environmental samples using pressurized accelerated hot solvent extraction. $\boldsymbol{J}$. Microbiol. Meth., v. 31, p. 19-27, 1997.

49 MCNULTY, H.; PENTIEVA, K. Folate bioavailability. Proc. Nutr. Soc., v. 63, p. 529-536, 2004.

50 MCNULTY, H.; PENTIEVA, K. Folate bioavailability. In: BAILEY, L.B. (Ed.). Folate in health and disease. 2. Ed. Boca Raton, FL, USA: CRC Press, 2009, p. 25-47.

51 MCKILLOP, D.; PENTIEVA, K.; DALY, D.; MCPARTLIN, J.; HUGHES, J.; STRAIN, J.; SCOTT, J.; MCNULTY, H. The effect of different cooking methods on folate retention in various foods that are amongst the major contributors to folate intake in the UK diet. Br. J. Nutr., v. 88, p. 681-688, 2002.

52 MITCHELL, L.E.; ADZICK, N.S.; MELCHIONNE, J.; PASQUARIELLO, P.S.; SUTTON, L.N.; WHITEHEAD, A.S. Spina bifida, Lancet, v. 364, p. 1885-95, 2004.

53 MOAT, S.; LANG, D.; MCDOWELL, I.; CLARKE, Z.; MADHAVAN, A.; LEWIS, M.; GOODFELLOW, J. Folate, homocysteine, endothelial function and cardiovascular disease. J. Nutr. Biochem., v. 15, p. 64-79, 2004. 
54 MOREHOUSE, M. Food irradiation - US regulatory considerations. Rad. Phys. Chem., v. 63, p. 281-284, 2002.

55 MÜLLER, H.; DIEHL, J. F. Effect of ionizing radiation on folates in food. Lebensm.-Wiss. u.-Technol., v. 29, p. 187-190, 1996.

56 MURPHY, M.; KEATING, M.; BOYLE, P.; WEIR, D.G.; SCOTT, J.M. The elucidation of the mechanism of folate catabolism in the rat. Biochem. Biophys. Res. Commun., v. 71, p. 1017-1024, 1976.

57 NAKKEN, K.F.; PIHL, A. The X-ray-induced damage to the p-aminobenzoic acid moiety of folic acid and some other $p$-aminobenzoic acid conjugates irradiated in solution. Radiat. Res., v. 27, p. 19-31, 1966.

58 OFF, M.K.; STEINDAL, A.E.; POROJNICU, A.C.; JUZENIENE, A.; VOROBEY, A.; JOHNSSON, A.; MOAN, J. Ultraviolet photodegradation of folic acid. J. Photochem. Photobio. B, v. 80, p. 47-55, 2005.

59 OSSEYI, E. S.; WEHLING, R. L.; ALBRECHT, J. A. Liquid chromatographic method for determining added folic acid in fortified cereal products. $J$. Chromatogr. A, v. 826, p. 235-240, 1998.

60 OTTEN, J.J.; HELLWIG, J.P.; MEYERS, L. Dietary Reference Intakes: The Essential Guide to Nutrient Requirements; The National Academies Press: Washington, EUA, 2006; p. 245-253.

61 PALLARONI, L.; VON HOLST, C. Determination of zearalenone from wheat and corn by pressurized liquid extraction and liquid chromatography-electrospray mass spectrometry. J. Chromatogr. A, v. 993, p. 39-45, 2003.

62 PATRING, J.; WANDEL, M.; JÄGERSTAD, M.; FROLICH, W. Folate content of Norwegian and Swedish flours and bread analysed by use of liquid chromatography - mass spectrometry. J. Food Compos. Anal., v. 22, p. 649-656, 2009.

63 PAWLOSKY, R.J., FLANAGAN, V.P. A quantitative stable-isotope LC-MS method for the determination of folic acid in fortified foods. J. Agric. Food Chem., v. 49 , p. 1282-1286, 2001.

64 PAWLOSKY, R.J.; HERTRAMPF, E.; FLANAGAN, V.P.; THOMAS, P.M. Mass spectral determinations of the folic acid content of fortified breads from Chile. J. Food Compos. Anal., v. 16, p. 281-286, 2003.

65 PENTEADO, M. D. V. C. Vitaminas, Aspectos nutricionais, bioquímicos, clínicos e analíticos. São Paulo, Brasil: Ed. Manole, 2003; p. 487492.

66 PFEIFFER, C. M.; ROGERS, L. M.; GREGORY III, J. F.. Determination of folate in cereal-grain food products using trienzyme extraction and combined affinity and reversed-phase liquid chromatography. J. Agric. Food Chem., v. 45, p. 407-413, 1997. 
67 PUWASTIEN, P.; PINPRAPAI, N.; JUDPRASONG, K.; TAMURA, T. International inter-laboratory analyses of food folate. J. Food Compos. Anal., v. 18, p. 387-397, 2005.

68 RYCHLIK, M. Simultaneous analysis of folic acid and pantothenic acid in foods enriched with vitamins by stable isotope dilution assays. Anal. Chim. Acta, v. 495, p. 133-141, 2003.

69 RYCHLIK, M. Revised folate content of foods determined by stable isotope dilution assays. J. Food Compos. Anal., v. 17, p. 475-483, 2004.

70 RYCHLIK, M.; ENGLERT, K.; KAPFER, S.; KIRCHHOFF, E. Folate contents of legumes determined by optimized enzyme treatment and stable isotope dilution assays. J. Food Compos. Anal., v. 20, p. 411-419, 2007.

71 RYLEY, J.; KAJDA, P. Vitamins in thermal processing. Food Chem., v. 49, p. 119-129, 1994.

72 SALCES, R. M. A.; KORTA, E.; BARRANCO, A.; GALLO, B.; VICENTE, F. Pressurized liquid extraction for the determination of polyphenols in apple. $\boldsymbol{J}$. Chromatogr. A, v. 933, p. 37-43, 2001.

73 SAUBERLICH, H.E.; KRETSCH, M.J.; SKALA, J.H.; JOHNSON, H.L.; TAYLOR, P.C. Folate requeriment and metabolism in nonpregnant women. $\boldsymbol{A m}$. $\boldsymbol{J}$. Clin. Nutr., v. 46, p. 1016-1028, 1987.

74 SAXBY, M.J.; SMITH, P.R.; BLAKE, C.J.; COVENEY, L.V. The degradation of folic acid in a model food system and in beer. Food Chem., v. 12, p. 115-126, 1983.

75 SCF (Scientific Committee on Food), 2000. Opinion of the Scientific Committee on Food on the Tolerable Upper Intake Level of Folate. European Commission, SCF/CS/NUT/UPPLEV 18 final, 28 Novembro 2000, Bruxelas. $<$ http://ec.europa.eu/food/fs/sc/scf/out80e_en.pdf>

76 SCURACHIO, R.S.; SKIBSTED, L.H.; METZKER, G.; CARDOSO, D.R. Photodegradation of folate sensitized by riboflavin. Photochem. Photobiol., v. 87, p. $840-845,2011$

77 SELHUB, J.; BAGLEY, L.; MILLER, J.; ROSENBERG, I. B vitamins, homocysteine, and neurocognitive function in the elderly. Am. J. Clin. Nutr., v. 71, p. 614S-620S, 2000.

78 SOUCI, S.W.; FACHMANN, W.; KRAUT, H. Food Composition and Nutrition Tables. Germany: CRC Press (Taylor \& Francis), 2008. p. 688-699.

79 SUITOR, C.W.; BAILEY, L.B. Dietary folates equivalents: interpretation and application. J. Am. Diet. Assoc., v. 100, p. 88-94, 2000.

80 TAMURA, T.; PICCIANO, M.F. Folate and human reproduction. Am. J. Clin. Nutr., v. 83, p. 993-1016, 2006. 
81 TANNENBAUM, S.R.; YOUNG, V.R.; ARCHER, M.C. Vitamins and minerals. In: FENNEMA, O.R. Food Chemistry. New York: Marcel Dekker, 1985. p. 477.1985.

82 TEMPLE, C. JR.; MONTGOMERY, J.A. Chemical and physical properties of folic acid and reduced derivatives. In: BLAKLEY, R.L.; BENKOVIC, S.J. (Ed.). Folates and Pterins. New York, NY: John Wiley \& Sons, 1984; v. 1, p. 61-120.

83 THOMAS, A.H.; SUÁREZ, G.; CABRERIZO, F.M.; MARTINO, R.; CAPPARELLI, A.L. Study of the photolysis of folic acid and 6-formylpterin in acid aqueous solutions. J. Photoch. Photobio. A, v. 135, p. $147-154,2000$.

84 TOSCHI, T. G.; BENDINI, A.; RICCI, A.; LERCKER, G. Pressurized solvent extraction of total lipids in poultry meat. Food Chem., v. 83, p. 551-555, 2003.

85 TRITSCH, G.L. Food irradiation. Rev. Nut., v. 16, n. 7/8, p. 698-701, 2000.

86 United States Pharmacopoeia (USP). United States Pharmacopoeia, 19th ed.; USP: Rockville, MD, 1975; p. 211-212.

87 VAHTERISTO, L.; LEHIKOINEN, K.; OLLILAINEN, V.; VARO, P. Application of an HPLC assay for the determination of folate derivatives in some vegetables, fruits and berries consumed in Finland. Food Chem., v. 59, n. 4, p. $589-597,1997$.

88 VERLINDE, P.; OEY, I.; HENDRICKX, M.; VAN LOEY, A. High pressure treatments induce folate polyglutamate profile changes in intact broccoli (Brassica oleraceae L. cv. italica) tissue.

89 VIKRAM, V.B.; RAMESH, M.N.; PRAPULLA, S.G. Thermal degradation kinetics of nutrients in orange juice heated by electromagnetic and conventional methods. J. Food Eng., v. 69, p. 31-40, 2005.

90 VILLAVICENCIO, A.L.C.H.; MANCINI-FILHO, J.; DELINCEÉ, H.; BOGNAR, A. Effect of gamma irradiation on the thiamine, riboflavin and vitamin B6 content in two varieties of Brazilian beans. Rad. Phys. Chem., v. 57, n. 3-6, p. $299-303$, 2000.

91 VON SOONTAG, C. The Chemical Basis of Radiation Biology. London, England: Taylor \& Francis, 1987. p. 31-77.

92 VORA, A.; RIGA, A.; DOLLIMORE, D.; ALEXANDER, K.S. Thermal stability of folic acid. Thermochim. Acta, v. 392-393, p. $209-220,2002$.

93 VOROBEY, P.; STEINDAL, A.E.; OFF, M.K.; VOROBEY, A.; MOAN, J. Influence of human serum albumin on photodegradation of folic acid in solution. Photochem. Photobiol., v. 82, p. 817 - 822, 2006.

94 World Health Organization (WHO). Safety and Nutritional Adequacy of Irradiated Food. Genebra, Suíca, 1994. p. 23-39. 
95 World Health Organization (WHO). Guidelines on food fortification with micronutrients. Allen, L.; de Benoist, B.; Dary, O.; Hurrell, R. Eds. Genebra, Suíca, 2006.

96 ZHOU, L.; LE GRANDOIS, J.; MARCHIONI, E.; ZHAO, M.; ENNAHAR, S.; BINDLER, F. Improvement of total lipid and glycerophospholipid recoveries from various food matrices using pressurized liquid extraction. J. Agric. Food Chem., v. 58, n. 18, p. 9912-9917, 2010. 